Florida International University FIU Digital Commons

$11-12-2010$

\title{
Synthesis of Aromatic Monothiols and Aromatic Dithiols to Increase the Folding Rate and Yield of Disulfide Containing Proteins
}

Amar S. Patel

Florida International University, apate001@fiu.edu

DOI: $10.25148 /$ etd.FI10120101

Follow this and additional works at: https://digitalcommons.fiu.edu/etd

\section{Recommended Citation}

Patel, Amar S., "Synthesis of Aromatic Monothiols and Aromatic Dithiols to Increase the Folding Rate and Yield of Disulfide Containing Proteins" (2010). FIU Electronic Theses and Dissertations. 313.

https://digitalcommons.fiu.edu/etd/313 


\section{FLORIDA INTERNATIONAL UNIVERSITY}

Miami, Florida

\section{SYNTHESIS OF AROMATIC MONOTHIOLS AND AROMATIC DITHIOLS TO INCREASE THE FOLDING RATE AND YIELD OF DISULFIDE CONTAINING PROTEINS}

A dissertation submitted in partial fulfillment of the requirements for the degree of DOCTOR OF PHILOSOPHY

in CHEMISTRY

by

Amar S. Patel 


\section{To: Dean Kenneth Furton}

College of Arts and Sciences

This dissertation, written by Amar S. Patel, and entitled Synthesis of Aromatic Monothiols and Aromatic Dithiols to Increase the Folding Rate and Yield of Disulfide Containing Proteins, having been approved in respect to style and intellectual content, is referred to you for judgment.

We have read this dissertation and recommend that it be approved.

\begin{tabular}{rr}
\hline Jose Almirall \\
\hline John Landrum \\
\hline Roberto Panepucci \\
\hline Stanislaw F. Wnuk \\
\hline Watson J. Lees, Major Professor
\end{tabular}

Date of Defense: November 12, 2010

The dissertation of Amar S. Patel is approved.

Dean Kenneth Furton

College of Arts and Sciences

Interim Dean Kevin O'Shea

University Graduate School

Florida International University, 2010 
C Copyright 2010 by Amar S. Patel

All rights reserved. 


\section{DEDICATION}

I dedicate this work to god, my loving wife, parents, brother, and sister in law for their patience and encouragement to complete my doctoral studies. Also to each and every member of my family and all friends who always supported me during this work. 


\section{ACKNOWLEDGMENTS}

I express my profound gratitude and indebtedness towards my mentor Dr. Watson J. Lees for giving me opportunity to work in his research group. I sincerely appreciate him for his keen interest, guidance, support, and encouragement which enabled me to complete my thesis. I would like to acknowledge his valuable inputs and the professional criticism throughout my research work as well as in writing my thesis. I am also grateful to other members of my dissertation committee, Dr. Jose Almirall, Dr. John Landrum, Dr. Roberto Panepucci, and Dr. Stanislaw Wnuk for their helpful suggestions during my thesis. Furthermore, I would also like to appreciate all the faculty members from the department of Chemistry and Biochemistry at Florida International University for their support and guidance and giving me opportunity to work as a teaching assistant for about three years during my doctoral studies. I am thankful to my lab mates for their support, time, and valuable input on my research as well as in writing thesis. Last but not the least, I would like to thank University Graduate School for supporting me with the Dissertation Year Fellowship which helped me during my last year of doctoral studies.

I specially acknowledge my wife, father, mother, brother, sister in law, all family members, and friends as they made my dream come true. 
ABSTRACT OF THE DISSERTATION

SYNTHESIS OF AROMATIC MONOTHIOLS AND AROMATIC DITHIOLS

TO INCREASE THE FOLDING RATE AND YIELD OF

DISULFIDE CONTAINING PROTEINS

\author{
by \\ Amar S. Patel \\ Florida International University, 2010 \\ Miami, Florida, \\ Professor Watson J. Lees, Major Professor
}

Most pharmaceutically relevant proteins and many extracellular proteins contain disulfide bonds. Formation of the correct disulfide bonds is essential for stability in almost all cases. Disulfide containing proteins can be rapidly and inexpensively overexpressed in bacteria. However, the overexpressed proteins usually form aggregates inside the bacteria, called inclusion bodies, which contains inactive and non-native protein. To obtain native protein, inclusion bodies need to be isolated and resolubilized, and then the resulting protein refolded in vitro. In vitro protein folding is aided by the addition of a redox buffer, which is composed of a small molecule disulfide and/or a small molecule thiol. The most commonly used redox buffer contains reduced and oxidized glutathione. Recently, aliphatic dithiols and aromatic monothiols have been employed as redox buffers. Aliphatic dithiols improved the yield of native protein as compared to the aliphatic thiol, glutathione. Dithiols mimic the in vivo protein folding catalyst, protein disulfide isomerase, which has two thiols per active site. Furthermore, aromatic monothiols increased the folding rate and yield of lysozyme and RNase A 
relative to glutathione. By combining the beneficial properties of aliphatic dithiols and aromatic monothiols, aromatic dithiols were designed and were expected to increase in vitro protein folding rates and yields.

Aromatic monothiols (1-4) and their corresponding disulfides (5-8), two series of ortho- and para-substituted ethylene glycol dithiols (9-15), and a series of aromatic quaternary ammonium salt dithiols (16-17) were synthesized on a multigram scale. Monothiols and disulfides (1-8) were utilized to fold lysozyme and bovine pancreatic trypsin inhibitor. Dithiols (11-17) were tested for their ability to fold lysozyme. At pH 7.0 and $\mathrm{pH} 8.0$, and high protein concentration $(1 \mathrm{mg} / \mathrm{mL})$, aromatic dithiols $(16,17)$ and a monothiol (3) significantly enhanced the in vitro folding rate and yield of lysozyme relative to the aliphatic thiol, glutathione. Additionally, aromatic dithiols $(16,17)$ significantly enhance the folding yield as compared to the corresponding aromatic monothiol (3). Thus, the folding rate and yield enhancements achieved in in vitro protein folding at high protein concentration will decrease the volume of renaturation solution required for large scale processes and consequently reduce processing time and cost. 


\section{TABLE OF CONTENTS}

CHAPTER

PAGE

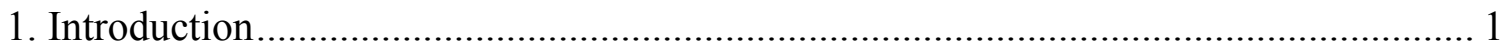

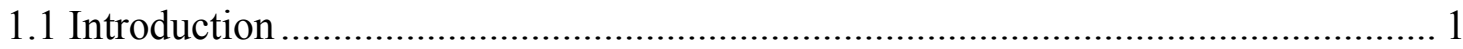

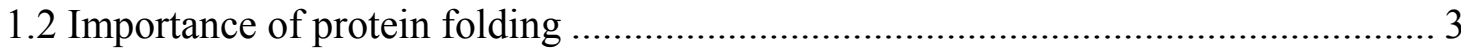

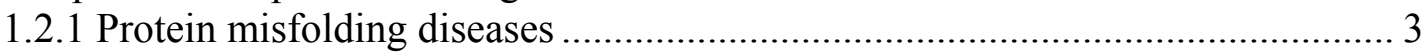

1.2.2 Protein folding by recombinant technology ................................................ 5

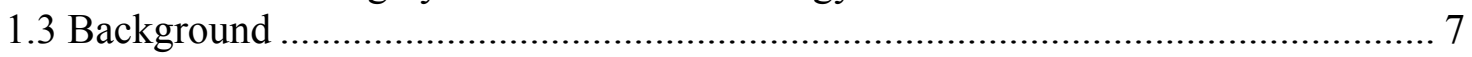

1.3.1 Thiol/disulfide interchange reaction........................................................... 7

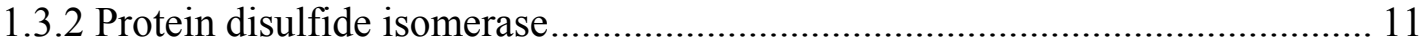

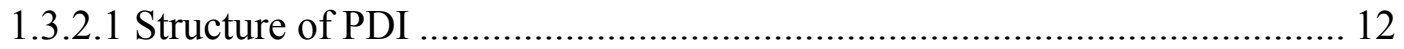

1.3.2.2 Chaperone and anti-chaperone activity of PDI in the oxidative folding

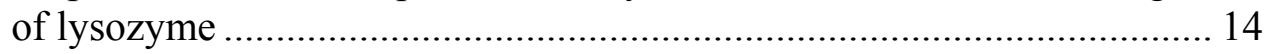

1.3.3 Role of Erolp and glutathione in oxidative protein folding ............................. 16

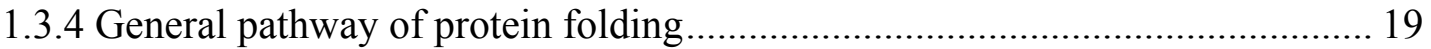

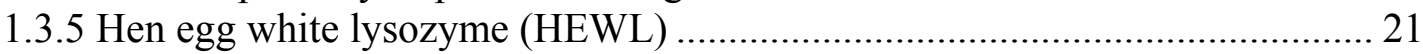

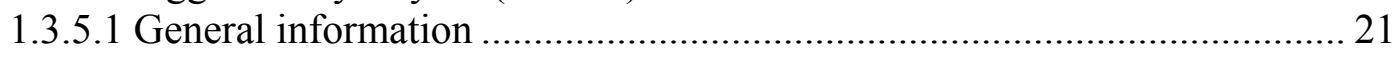

1.3.5.2 Distributions of conformers during lysozyme folding ............................... 23

1.3.5.3 Refolding kinetics of the three-disulfide intermediates ............................ 25

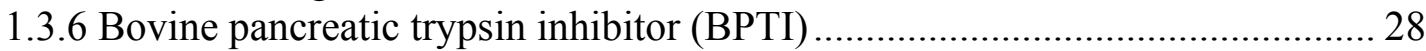

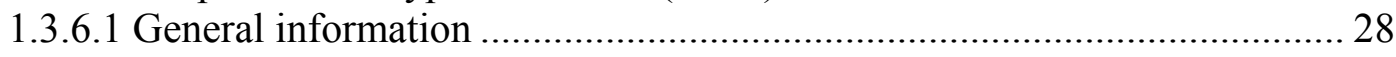

1.3.6.2 Folding pathway of BPTI as proposed by Kim et al.................................. 29

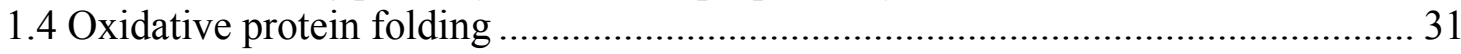

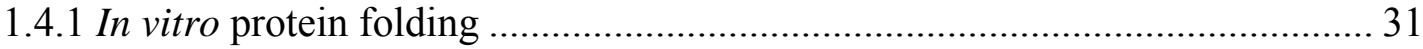

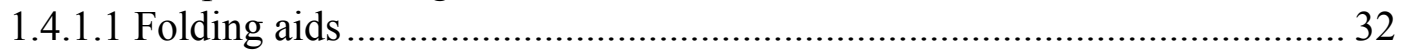

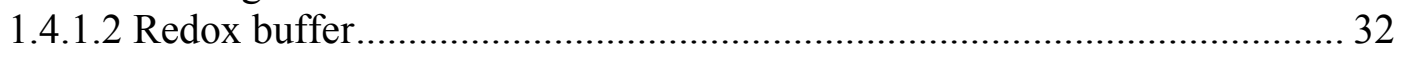

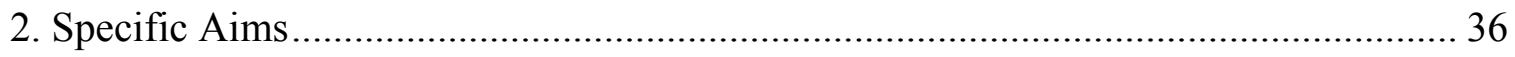

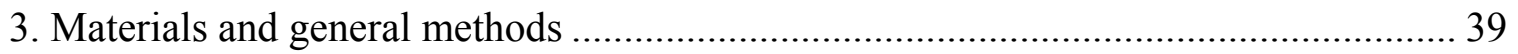

3.1 Synthesis of aromatic monothiols and their corresponding disulfides $(1-8)$.......... 39

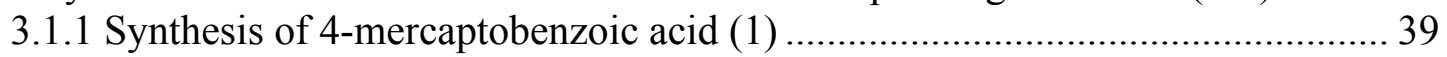

3.1.1.1 Synthesis of methyl 4-(dimethylcarbamothioyloxy)benzoate (20)............. 39

3.1.1.2 Synthesis of methyl 4-(dimethylcarbamoylthio)benzoate (21) ................... 40

3.1.1.3 Synthesis of 4-mercaptobenzoic acid (1) .................................................... 41

3.1.1.4 Synthesis of disulfide of 4-mercaptobenzoic acid (5) ................................. 41

3.1.2 Synthesis of 4-mercaptobenzylphosphonic acid (2) ....................................... 42

3.1.2.1 Synthesis of $S$ - $p$-tolyl benzothioate (24) ……….................................... 42

3.1.2.2 Synthesis of $S-4$-(bromomethyl)phenyl benzothioate (25) ....................... 43

3.1.2.3 Synthesis of S-4-((diethoxyphosphoryl)methyl)phenyl benzothioate (26) 43

3.1.2.4 Synthesis of S-4-((diethoxyphosphoryl)methyl)phenyl ethanethioate (27) 44

3.1.2.5 Synthesis of 4-mercaptobenzylphosphonic acid (2)................................... 45

3.1.2.6 Synthesis of disulfide of 4-mercaptobenzylphosphonic acid (6) ............... 46 
3.1.3 Synthesis of quaternary ammonium thiol salt (Mono QAS) (3)

3.1.3.1 Synthesis of 1-(4-(benzoylthio)phenyl)- $N, N, N$-trimethylmethanaminium bromide [quaternary ammonium salt (28)]

3.1.3.2 Synthesis of 1-(4-(mercaptophenyl)- $N, N, N$-trimethylmethanaminium bromide [Mono QAS (3)]

3.1.3.3 Synthesis of disulfide of Mono QAS (7) .................................................. 47

3.1.4. Synthesis of 4-mercaptobenzene sulfonic acid (4)......................................... 48

3.1.4.1 Synthesis of 4-mercaptobenzene sulfonic acid (4)................................... 48

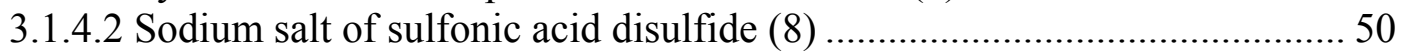

3.2 Synthesis of ortho-and para-substituted aromatic ethylene glycol dithiols (9-15). 50

3.2.1 Synthesis of di-, tri-, tetra-, and hexaethylene glycol thiols

$(35,36,43$, and 44$)$.....

3.2.1.1 Synthesis of 2-(2-mercaptoethoxy)ethanol and 2-[2-(2mercaptoethoxy)ethoxy] ethanol [di- and triethylene glycol thiols (35 and 36)]

3.2.1.2 Synthesis of 2-[2-(2-(2-hydroxyethoxy)ethoxy)ethoxy]ethyl-4methylbenzenesulfonate and 17-hydroxy-3,6,9,12,15pentaoxaheptadecyl-4-methylbenzenesulfonate [tetra- and hexaethylene glycol monotosylate (41 and 42)].

3.2.1.3 Synthesis of 2-[2-(2-(2-mercaptoethoxy)ethoxy)ethoxy]ethanol and 17mercapto-3,6,9,12,15-pentaoxaheptadecan-1-ol [tetra- and hexaethylene glycol thiol (43 and 44)]

3.2.2 Synthesis of di-, tri-, tetra-, and hexaethylene glycol disulfides

$(37,38,45$, and 46$)$ 54

3.2.3 Synthesis of ortho- and para-substituted aromatic ethylene glycol dithiols polymer.

3.2.4 Reduction of ortho- and para-substituted aromatic ethylene glycol dithiol

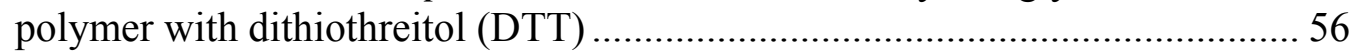

3.3 Synthesis of aromatic triethylene glycol monothiol (61) ……................................59

3.3.1 Synthesis of aromatic triethylene glycol disulfide (60)....................................59

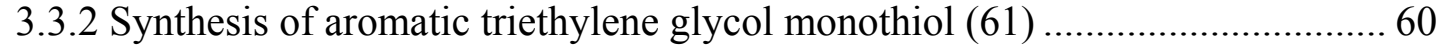

3.4 Synthesis of Di quaternary salt dithiols (Di QAS 16 and 17) .................................. 61

3.4.1 Synthesis of $N^{1}, N^{3}$-bis(4-benzoylthio)benzyl)- $N^{1}, N^{1}, N^{3}, N^{3}$ -

tetramethylpropane-1,3-diaminium bromide (67)

3.4.2 Synthesis of $N^{1}, N^{3}$-bis(4-mercaptobenzyl)- $N^{1}, N^{1}, N^{3}, N^{3}-$

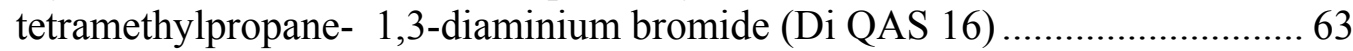

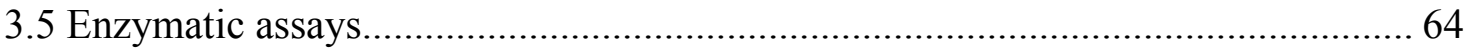

3.5.1 Preparation of reduced denatured lysozyme......................................................... 64

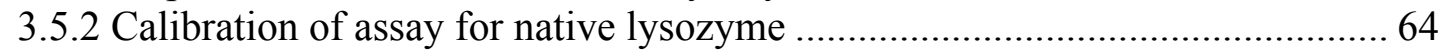

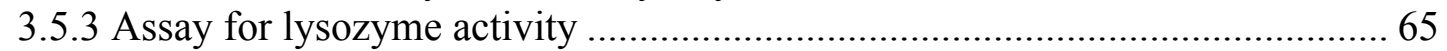

3.5.4 Refolding of denatured reduced lysozyme $(0.1 \mathrm{mg} / \mathrm{mL})$............................... 65

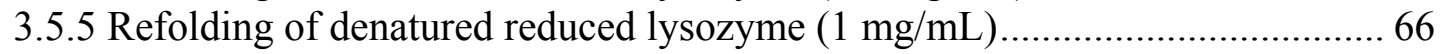

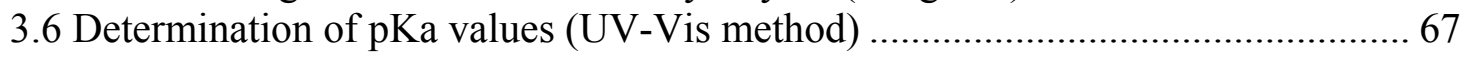

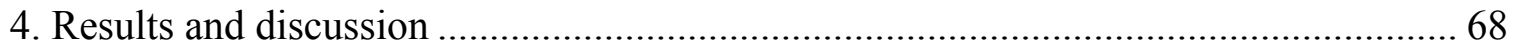


4.1 Synthesis of aromatic monothiols (1-4) and their corresponding disulfides

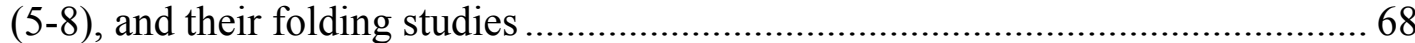

4.1.1 Synthesis of 4-mercaptobenzoic acid (1) and its disulfide (5) .......................... 69

4.1.2 Synthesis of 4-mercaptobenzylphosphonic acid (2) .......................................... 69

4.1.3 Synthesis of Mono QAS (3) and its disulfide (7) …………………............... 71

4.1.4 Synthesis of 4-mercaptobenzenesulfonic acid (4) and its disulfide (8)............ 71

4.1.5 Folding studies with aromatic monothiols and their disulfides........................ 73

4.1.5.1 Folding of BPTI in the presence of GSSG, phosphonic acid disulfide (6), quaternary ammonium salt disulfide (7), and sulfonic acid disulfide (8) .... 73

4.1.5.2 Folding of lysozyme with aromatic monothiols ( 2 and 3 ) and their corresponding disulfides $(6$ and 7$)$........................................................ 74

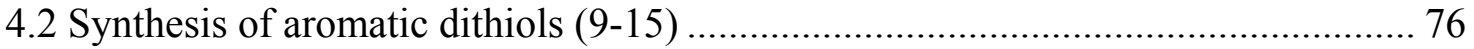

4.2.1 Synthesis of ortho- and para-substituted aromatic ethylene glycol

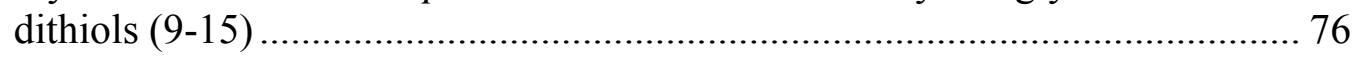

4.2.1.1 Synthesis of di-, tri-, tetra- and hexaethylene glycol disulfides

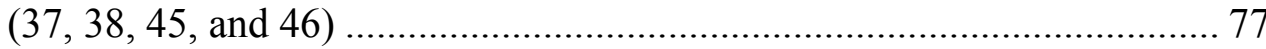

4.2.1.2 Synthesis of ortho-substituted aromatic mono-, di-, tri-, and tetraethylene glycol dithiols (9-12) ....................................................... 78

4.2.1.3 Synthesis of para-substituted aromatic di-, tri-, and tetraethylene

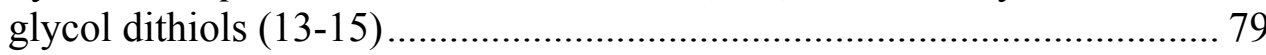

4.2.1.4 Folding of lysozyme with ortho-substituted aromatic ethylene

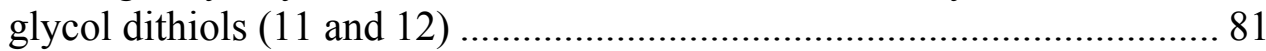

4.2.1.5. Folding of lysozyme with para -series of aromatic ethylene glycol

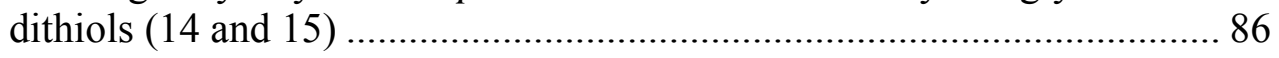

4.2.1.6 Synthesis and folding studies with para-substituted aromatic diethylene glycol dithiol (13) .................................................................. 91

4.2.1.7 Synthesis and folding studies with aromatic triethylene glycol monothiol (61) ............................................................................ 93

4.2.1.8 Folding studies with triethylene glycol monothiol (36) ............................. 94

4.3 Di Quaternary ammonium aromatic dithiols (16 and 17) ..................................... 97

4.3.1 Synthesis of aromatic di quaternary ammonium salt dithiols (16 and 17) f.....99

4.3.2 Folding of lysozyme with Di QAS (16 and 17)............................................. 98

$4.4 \mathrm{pKa}$ Values of aromatic monothiols and aromatic dithiols ................................... 104

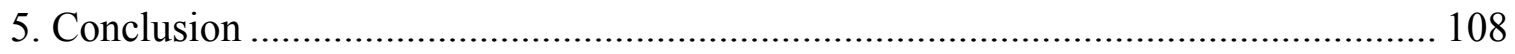

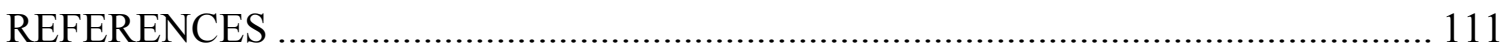

VITA Error! Bookmark not defined. 


\section{LIST OF TABLES}

TABLE

PAGE

1. Folding of lysozyme with ortho-aromatic dithiol (11) at $\mathrm{pH} 7.0$ and $8.0 \ldots \ldots \ldots \ldots \ldots \ldots \ldots . . .84$

2. Folding of lysozyme with ortho-aromatic dithiol (12) at pH 7.0 and $8.0 \ldots \ldots \ldots \ldots \ldots \ldots \ldots . . . .85$

3. Folding of lysozyme with para-aromatic dithiol (14) at $\mathrm{pH} 7.0$ and $8.0 \ldots \ldots \ldots \ldots \ldots \ldots \ldots . . . .89$

4. Folding of lysozyme with para-aromatic dithiol (15) at $\mathrm{pH} 7.0$ and 8.0.................... 90

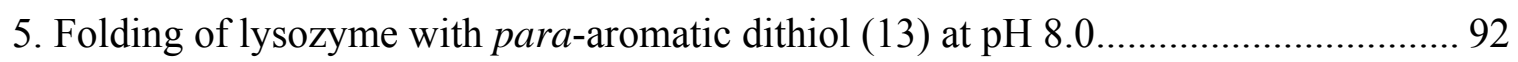

6. Folding of lysozyme with aromatic monothiol (61) at $\mathrm{pH} 8.0 \ldots \ldots \ldots \ldots \ldots \ldots \ldots \ldots \ldots \ldots \ldots \ldots . . . .94$

7. Folding of lysozyme with triethylene glycol monothiol (36) at $\mathrm{pH} 8.0$...................... 95

8. Folding of lysozyme $(0.1 \mathrm{mg} / \mathrm{mL})$ with DI QAS (16) and GSH at $\mathrm{pH} 7.0$ and 8.0..... 99

9. Folding of lysozyme $(0.1 \mathrm{mg} / \mathrm{mL})$ with DI QAS (17) and GSH at $\mathrm{pH} 7.0$ and $8.0 \ldots .100$

10. Folding of lysozyme (1 mg/mL) with Mono QAS (3), Di QAS (16), Di QAS (17),

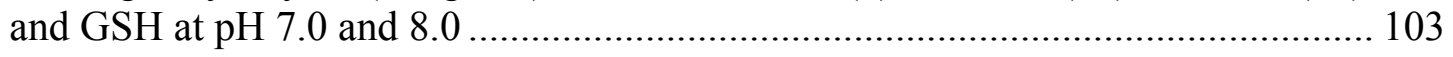

11. pKa Values of aromatic monothiols and aromatic dithiols....................................... 105 


\section{LIST OF FIGURES}

FIGURE

PAGE

1. Diagrammatic representation of the stages of protein formation................................ 2

2. Schematic representation of protein misfolding which may results in diseases........... 4

3. Protein expression by recombinant DNA technology. ........................................... 5

4. Thiol/disulfide interchange reactions with a small molecule thiol (RSH) and a small molecule disulfide (RSSR) that occur during in vitro protein folding. .... 11

5. Domains of human PDI, numbering is for full length human PDI........................... 12

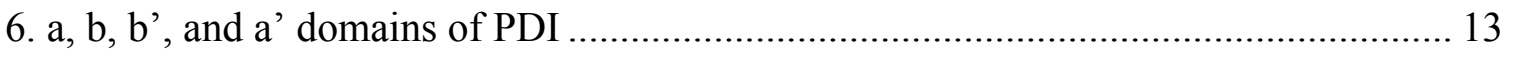

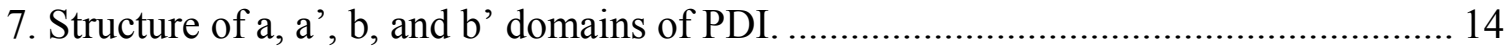

8. Proposed model for the chaperone and anti-chaperone activity of PDI by Puig et al. . 16

9. Native disulfide bond formation in the ER of the lumen by PDI via Ero1p................ 18

10. Generic folding pathways disulfide containing protein as proposed by

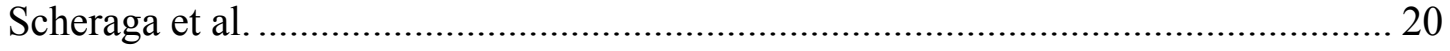

11. Rasmol representations of native hen egg white lysozyme …............................... 22

12. Schematic diagram of possible disulfide intermediates during the folding of

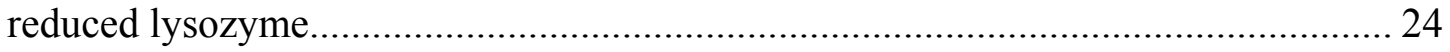

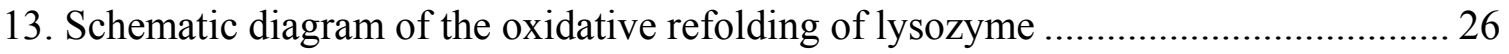

14. Rasmol representations of bovine pancreatic trypsin inhibitor..............................29

15. Folding pathway of BPTI with a) one disulfide intermediate, b) two disulfide intermediate, and c) native protein

16. Schematic representation of folding pathway of BPTI as proposed by Kim et al..... 30

17. a) Thiol/disulfide interchange reaction with dithiols showing escape mechanism..... 34

18. HPLC chromatograms of a folding mixture of BPTI ........................................ 73 
19. Folding of lysozyme at $1 \mathrm{mg} / \mathrm{mL}$ at $\mathrm{pH} 7.0$ and 8.0 with monothiol (2) .................. 75

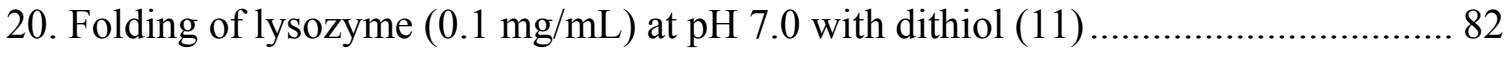

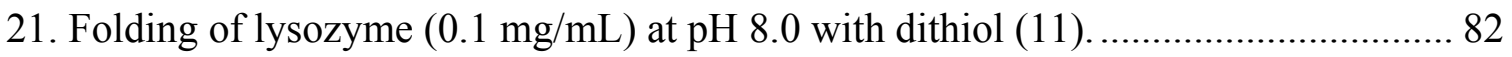

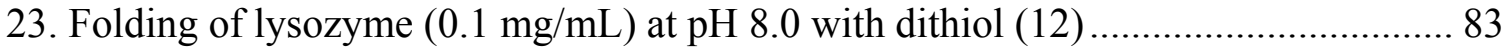

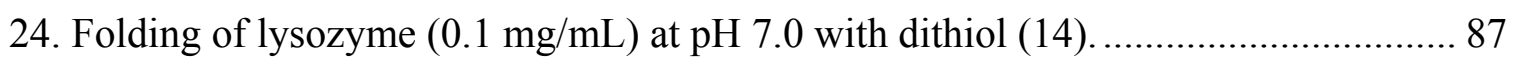

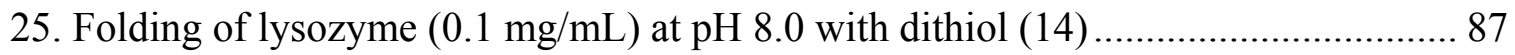

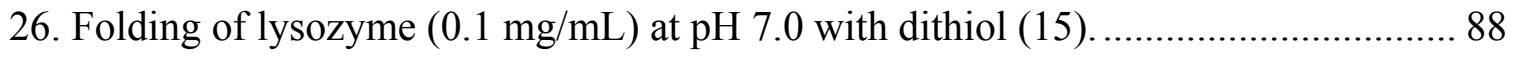

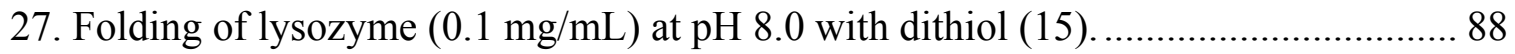

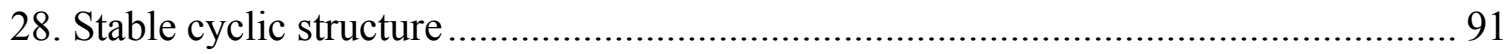

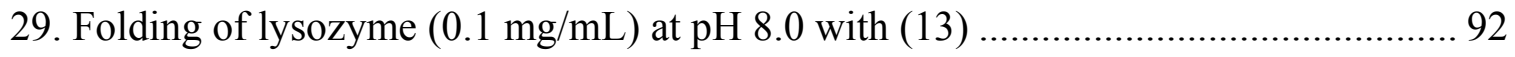

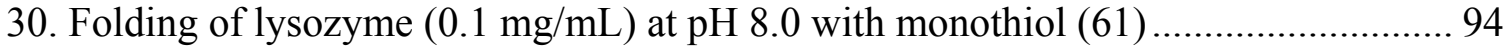

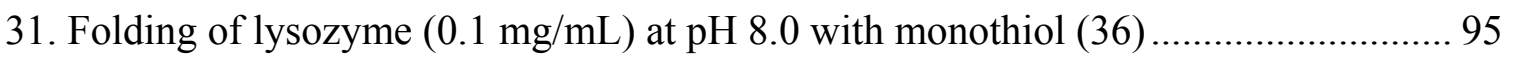

32. Folding of lysozyme (1 mg/mL) at pH 7.0 and 8.0 with monothiol (3), dithiol (16),

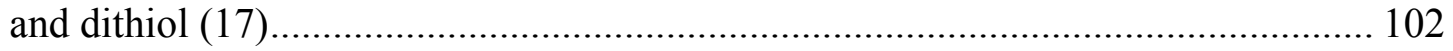

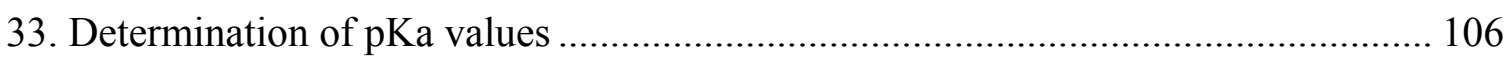

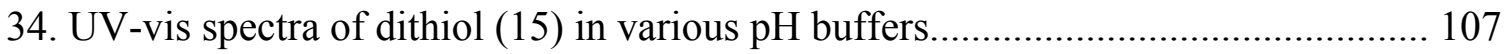




\section{LIST OF SCHEMES}

SCHEME

PAGE

1. Mechanism for thiol/disulfide interchange reaction ......................................... 8

2. Role of redox buffer thiol in thiol/disulfide interchange reactions............................ 9

3. Synthesis of 4-mercaptobenzoic acid (1) and its disulfide (5) ....................................69

4. Synthesis of 4-mercaptobenzylphosphonic acid (2) and its disulfide (6) ................... 70

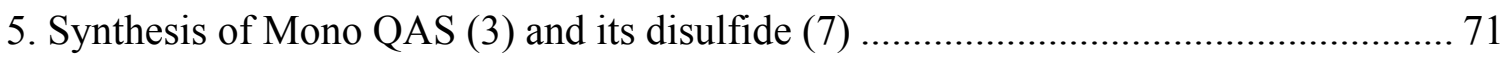

6. Synthesis of 4-mercaptobenzenesulfonic acid (4) and its disulfide (8) ...................... 72

7. Synthesis of di- and triethylene glycol disulfides (37 and 38) .................................77

8. Synthesis of tetra- and hexaethylene glycol disulfides (45 and 46)........................ 78

9. Synthesis of (ortho) mono-, di-, tri-, and tetraethylene glycol dithiols (9-12) ........... 78

10. Synthesis of (para) di-, tri-, and tetraethylene glycol dithiols $(13-15) \ldots \ldots \ldots \ldots \ldots \ldots \ldots . . . . . . . . . . .79$

11. Synthesis of aromatic triethylene glycol monothiol (61).................................... 93

12. Synthesis of aromatic di quaternary ammonium salt dithiols (16 and 17) ............... 98 


\section{Chapter 1}

\section{Introduction}

\subsection{Introduction}

Proteins are the most abundant organic molecules in living organisms. They occur in every part of the cell and constitute about $50 \%$ of cellular dry weight. Proteins form the fundamental basis of life. ${ }^{1}$ The human body contains approximately 100,000 different types of proteins, and each protein has its own function, such as catalysis, transport and storage of small molecules and ions, growth control, and mechanical support. Furthermore, proteins perform regulatory roles including monitoring extracellular and intracellular conditions, and passing information to other cellular components. One striking feature is that most known enzymes are proteins. Enzymes are macromolecules that catalyze most of the chemical reactions in biological systems, and can increase reaction rates by many orders of magnitude.

Proteins are composed approximately 20 different amino acids, and each amino acid is connected to another by a peptide bond to form a polypeptide chain. ${ }^{1}$ The structure of proteins is divided into four levels (Figure 1):

a) Primary structure is the sequence of amino acids joined by peptide bonds to form a polypeptide chain;

b) Secondary structure refers to the spatial arrangement of amino acids residues that are nearby in the sequence, these arrangements are regular and give rise to alpha helices and beta sheets;

c) Tertiary structure refers to the spatial arrangement of amino acids residues that are far apart in the sequence and to the pattern of disulfide bonds; 
d) Quaternary structure refers to the spatial arrangement of polypeptide chains and the nature of their interaction.

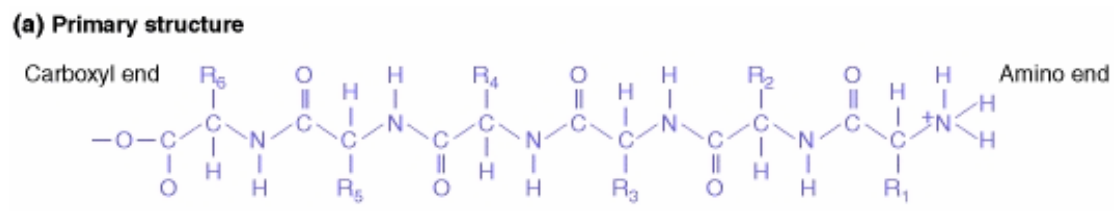

(b) Secondary structure

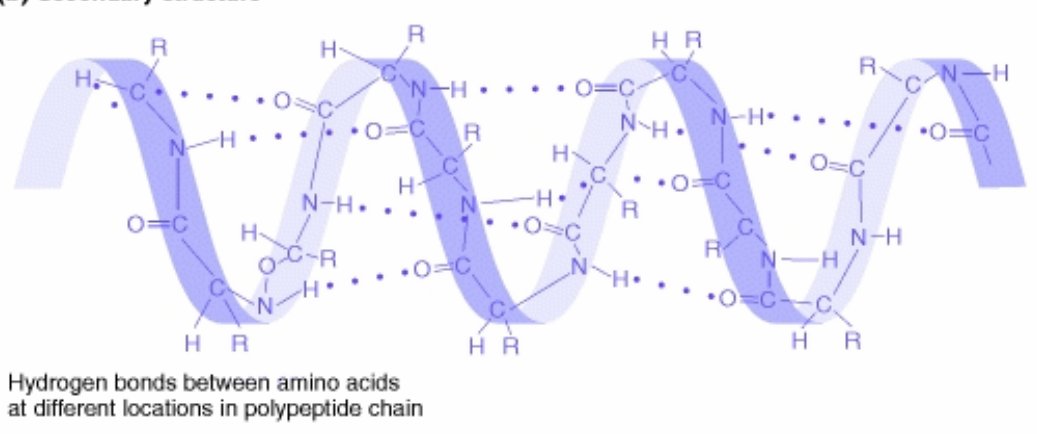

(c) Tertiary structure

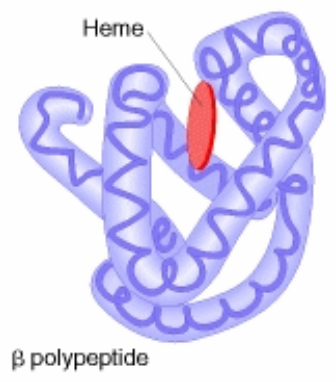

(d) Quaternary structure

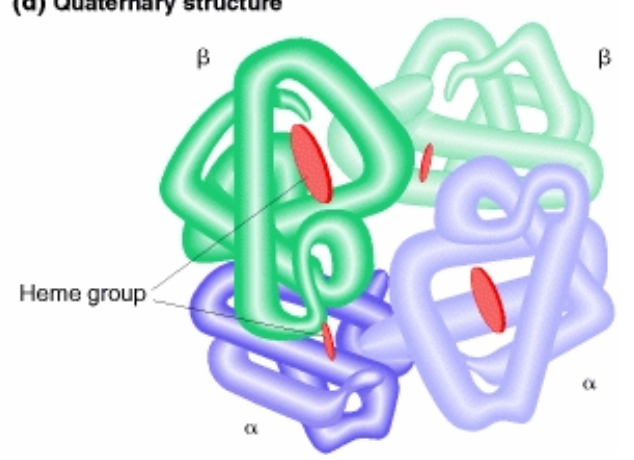

Figure 1. Diagrammatic representation of the stages of protein formation. a) Primary structure, b) Secondary structure, c) Tertiary structure of myoglobin, and d) Quaternary structure of hemoglobin. Figure from Griffiths, W., 1999. ${ }^{2}$

Proteins are initially synthesized as linear polypeptide chains that are eventually extruded from ribosome. At this stage, the proteins are considered to be nonnative and nonfunctional. In order to become native and functional, proteins have to shield their exposed hydrophobic residues and adopt a precise tertiary structure. It is well known that the primary amino acid sequence determines the tertiary structure of proteins, but how 
folding occurs to form native protein is still the subject of intense investigation. Many experiments have been conducted to gain insight into how proteins efficiently acquire their three dimensional structure. ${ }^{3}$ Additionally, an understanding of protein folding would provide a basis for the design of proteins and help in structure prediction from the amino acids sequence.

Although the amino acid sequence specifies the tertiary structure of proteins, the formation of native disulfide bonds plays an important role in the biosynthesis of many extracellular proteins including most pharmaceutically relevant proteins. ${ }^{4}$ The formation of the correct disulfide bonds between cysteine residues is essential for stability and activity in almost all cases. Disulfide bonds stabilize the native three dimensional structure of proteins by lowering the entropy of the unfolded state and by forming energetically favorable interactions in the native state. ${ }^{5}$ Failure to form the correct disulfide bonds may lead to protein misfolding, aggregation, and degradation by proteases which can result in various neurodegenerative diseases. ${ }^{6}$

\subsection{Importance of protein folding}

\subsubsection{Protein misfolding diseases}

Protein folding and unfolding are coupled to many significant events in the functioning of a biological systems, including translocation of proteins across membranes, secretion of extracellular proteins, protein trafficking, and the control and regulation of the cell cycle. ${ }^{7}$ Many human diseases arise from the failure of a specific peptide or protein to adopt or remain in its native functional conformational state, which leads to protein aggregation. These pathological disorders are generally referred to as protein misfolding diseases and recently, were grouped under the name of protein 
conformational disorders (PCDs). ${ }^{8}$ The diseases in this group include Alzheimer's disease, transmissible spongiform encephalopathies, Hungtington disease, cystic fibrosis, type II diabetes, mad cow disease, Parkinson's disease, Crutzfeldt-Jacob disease, and cancer. $^{6,9-12}$ The characteristic feature of PCDs is a change in the secondary and/or tertiary structure of a normal protein without any change in the primary structure. These conformational changes may lead to various diseases by either the gain of toxic activity or by the loss of biological activity (Figure 2). ${ }^{13,14}$

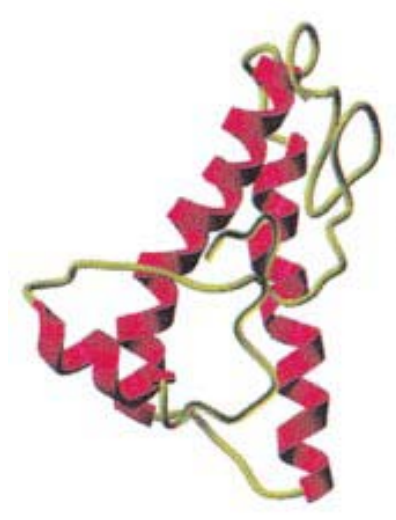

Normal protein (folded structure)

\section{CONFORMATIONAL}
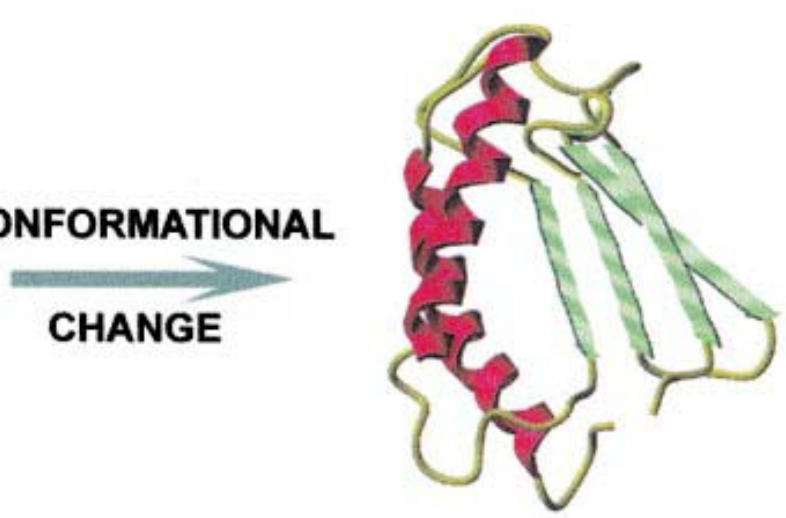

Disease-associated protein (misfolded structure)

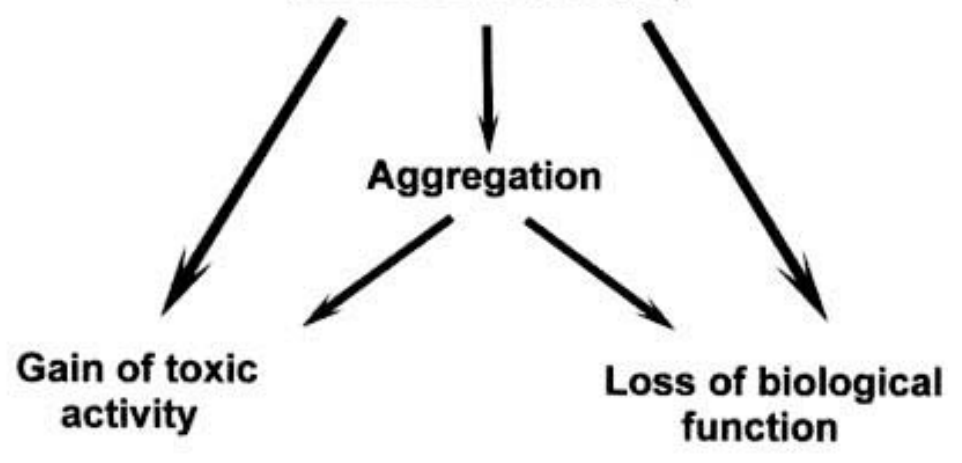

Figure 2. Schematic representation of protein misfolding which may results in diseases from Soto, C., 2001. ${ }^{10}$ 


\subsubsection{Protein folding by recombinant technology}

Recombinant DNA technology allows the large scale synthesis of proteins for both research and industrial purposes. Recombinant technology, which was developed from decades of basic research on the nature of DNA, has allowed the synthesis of many useful proteins such as insulin and provided a vital tool for studying gene activity. ${ }^{15}$ With biotechnology, high value proteins can be overexpressed in bacteria in a rapid and inexpensive way. However, overexpressed proteins, especially disulfide containing proteins, can be deposited as insoluble inactive aggregates (inclusion bodies) in the host cell. The protein within these aggregates is usually inactive and non-native. To obtain the native protein, it is necessary to isolate the aggregates, resolubilize the protein, and fold the protein in vitro (Figure 3). ${ }^{16}$ The formation of the correct disulfide bonds during in vitro protein folding is the slowest and the rate-determining step.

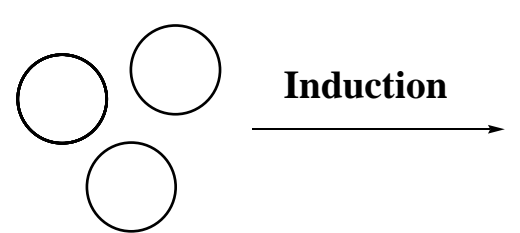

E.coli
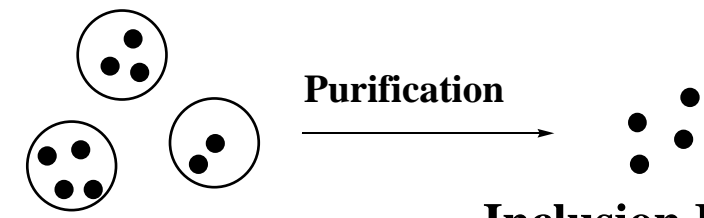

Inclusion Bodies (Inactive protein)

1) Isolation

2) Solubilization

Active Protein

\section{Inclusion Bodies}

3) In vitro folding

Figure 3. Protein expression by recombinant DNA technology.

The common process to recover native protein from inclusion bodies involves 3 steps: 
a) Isolation of inclusion bodies- Inclusion bodies have relatively high specific density, and thus can be harvested after cell lysis by centrifugation at moderate rotor speeds. ${ }^{17}$

b) Inclusion bodies solubilization- Solubilization of inclusion bodies can be accomplished using strong denaturants such as $6 \mathrm{M}$ guanidium $\mathrm{HCl}(\mathrm{Gdn} \mathrm{HCl})$ or 6-8 $M$ urea, which disrupts noncovalent bonds between polypeptide chains. ${ }^{18}$ Two reasons $\mathrm{Gdn} \mathrm{HCl}$ preferred over urea are: First, $\mathrm{Gdn} \mathrm{HCl}$ is a strong chaotroph, which can solubilize strong sturdy inclusion bodies; Second, urea may decompose to give cyanate ions, which can irreversibly modify the amino acids residues of the protein especially upon long term incubation at alkaline $\mathrm{pH} .{ }^{19}$ The isolated inclusion bodies of cysteine containing proteins usually contain interchain disulfide bonds which reduce solubility of the inclusion bodies. ${ }^{20}$ Thus, low molecular weight thiol reagents are usually added in combination with chaotrophs to reduce the interchain disulfide bonds by thiol/disulfide interchange reactions. Thiol reagents such as dithiothreitol, dithioerythritol, glutathione, cysteine, cystamine, or 2-mercaptoethanol can be employed. Furthermore, detergents have also been used to solubilize inclusion bodies. Most commonly used detergents are sodium dodecyl sulfate (SDS) and n-cetyl trimethylammonium bromide (CTAB) ${ }^{21}$

c) Refolding of solubilized protein- The refolding step should be optimized for each protein in order to get the highest yield of active protein. The general procedure for refolding involves the removal of denaturant, thereby allowing the polypeptide to recover its native structure. Denaturant can be removed by several methods including dilution, dialysis, diafiltration gel filtration, and immobilization on solid support. The dilution method involves diluting the denatured protein solution into refolding buffer 
which reduces the chaotrope concentration and provides a suitable environment for the protein to refold. Dilution has been used to fold many proteins such as antibody fragments, interleukin 2, M-CSF, and pro-urokinase. ${ }^{22-25}$ The major drawback of the dilution method is the requirement for large processing volumes which increases the overall cost. In dialysis, the concentration of denaturant is reduced by dialyzing against refolding buffer. As the concentration of chaotrope decreases, the protein starts to refold. Dialysis membranes are semi-permeable membranes, which allow the transport of small molecules across the membrane and retain the large molecules. The process is driven by the osmotic pressure difference across the membrane. Examples of proteins folded by dialysis are citrate synthase, chymotrypsinogen, and urokinase. ${ }^{26-28}$ As the process of dialysis is controlled by osmotic pressure, dialysis may be too slow to be employed in commercial scale production of proteins. As an alternative, diafiltration can be used for removal of denaturant and refolding of proteins. Diafiltration is a pressure driven process using ultrafiltration membranes of specific membrane size which allows the transport of small molecule chaotrope across the membrane while retaining the protein. Simultaneously, refolding buffer is added at the same rate as solvent passes through the membrane. Examples of proteins folded by diafiltration are prorennin and carbonic anhydrase..$^{28,29}$

\subsection{Background}

\subsubsection{Thiol/disulfide interchange reaction}

Most pharmaceutically relevant proteins and many extracellular proteins contain disulfide bonds. When these proteins are overexpressed in bacteria, they usually produce inclusion bodies. To obtain these proteins in their biologically active form, it is necessary 
to resolubilize the inclusion bodies and then fold the protein in vitro. In in vitro protein folding, a significant challenge is the formation of the correct disulfide bonds between cysteine residues. Disulfide bonds are the only covalent bonds formed during folding and their formation is usually slow and thus the rate determining step. Disulfide bond formation involves thiol/disulfide interchange reactions as shown in scheme 1 . The mechanism involves the nucleophilic attack of a thiolate anion $\left(\mathrm{R}_{1} \mathrm{~S}^{-}\right)$on a disulfide bond $\left(\mathrm{R}_{2} \mathrm{SSR}_{3}\right)$, displacing one sulfur $\left(\mathrm{R}_{3} \mathrm{~S}\right)$ of the disulfide bond and forming a new disulfide bond $\left(\mathrm{R}_{1} \mathrm{SSR}_{2}\right) . \mathrm{R}_{3} \mathrm{~S}^{-}$acts as the leaving group and $\mathrm{R}_{2} \mathrm{~S}$ acts as the center sulfur. ${ }^{5}$ As the number of cysteine residues increases, the probability of forming non-native disulfide bonds increases exponentially.

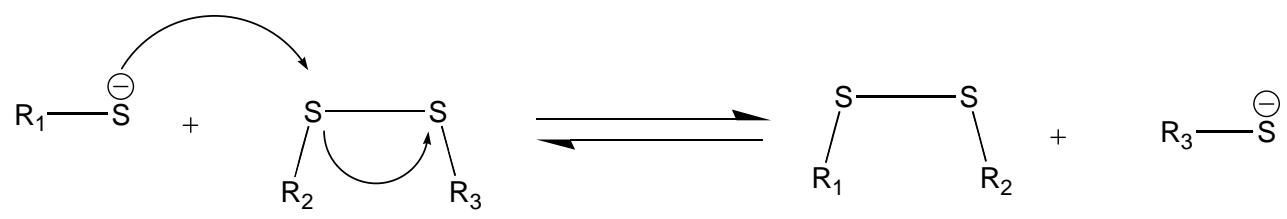

Thiolate Disulfide bond New disulfide bond Leaving group

Scheme 1. Mechanism for thiol/disulfide interchange reaction

To enhance the in vitro folding rate of disulfide containing proteins, protein catalysts and a limited number of small molecule thiols have been used., ${ }^{4,5,30-33}$ Protein catalysts, such as protein disulfide isomerase (PDI), which is used in vivo, can increase in vitro protein folding rates significantly. However, the use of PDI for in vitro folding is impractical because of its high cost and the amount of PDI required to achieve significant rate enhancements. ${ }^{31}$ Small molecule aliphatic thiols, such as glutathione (GSH), cysteine, and dithiothreitol (DTT) are usually employed for in vitro protein folding. ${ }^{5,33} \mathrm{~A}$ small molecule thiol is generally used in combination with a small molecule disulfide, to 
form a redox buffer, for example oxidized glutathione (GSSG) and reduced glutathione (GSH). Although protein folding rates with small molecule thiols are slower than those obtained with PDI, small molecule thiols are less expensive and can easily be removed from the native protein. Recently, more efficient redox buffers containing aliphatic dithiols, synthetic peptides, or aromatic monothiols have been employed as redox buffers. $^{32,34-38}$

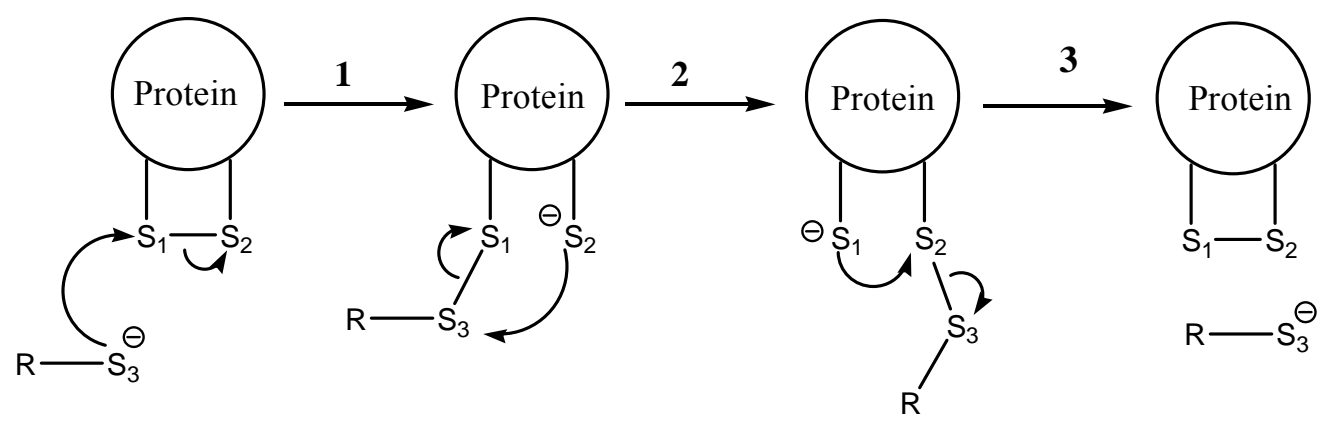

Scheme 2. Role of redox buffer thiol in thiol/disulfide interchange reactions, where the redox buffer thiol ( $\left(\mathrm{R}-\mathrm{S}_{3}\right)$ can act as 1) a nucleophile, 2) a center thiol, and 3) a leaving group. ${ }^{39}$

The folding pathways of several disulfide containing proteins have been well characterized. ${ }^{5,40-42}$ Each of these pathways involves multiple thiol/disulfide interchange reactions between the protein and small molecule thiols and disulfides. Several factors may influence the rate of formation of disulfide bonds, such as the concentration of the thiolate anions, accessibility, proximity, and reactivity of the thiol group and disulfide bonds. ${ }^{5,41}$ The concentration of the thiolate anion depends on several factors such as total thiol concentration, the thiol $\mathrm{pK}_{\mathrm{a}}$, and the solution $\mathrm{pH}^{35}$ The thiol in its deprotonated form can act as a nucleophile or a leaving group, and thiol in a disulfide can act as a center thiol (Scheme 2) ${ }^{35}$ Disulfide bond formation can be inhibited by the burial of reactive groups, such as protein thiol groups, protein disulfide bonds, and mixed disulfide 
bonds, in a stable tertiary structure. For instance, the burial of the disulfide bonds in stable tertiary structures prevents their reduction and reshuffling. On the other hand, the segregation of two protein thiols can inhibit the formation of a disulfide bond between them. Thus, stable tertiary structures can inhibit the contacts between the thiolates and disulfides and thereby affect their reactivity.

The thiol/disulfide interchange reaction can occur intramolecularly, that is within the protein itself, or intermolecularly between the protein and the redox buffer. ${ }^{5}$ During the in vitro folding of disulfide containing proteins, there are 8 possible types of the thiol/disulfide interchange reaction that can occur. In the first four reactions (Figure 4, AD), the protein thiolate acts as a nucleophile, while the small molecule thiolate acts as a nucleophile in the last four reactions (Figure 4, E-H). The thiolates can nucleophilically attack one of several disulfides, a protein disulfide (Figure 4, A and E); a small molecule disulfide (Figure 4, B and F); a mixed disulfide between a small molecule thiol and a protein thiol at either the sulfur attached to the protein (Figure 4, C and G) or the small molecule (Figure 4, D and H).

Moreover, the rates of almost all of the thiol/disulfide interchange reactions can be increased by aromatic thiols compared to aliphatic thiols under standard conditions. The reasons are that aromatic thiols are better nucleophiles, better leaving groups, and better center thiols than aliphatic thiols such as glutathione at $\mathrm{pH} 7.0$ or $7.7 .^{43,44}$ Aromatic thiolates are better nucleophiles than aliphatic thiolates with similar thiol $\mathrm{pK}_{\mathrm{a}}$ values. ${ }^{43}$ Moreover, the leaving group ability of thiols is inversely proportional to the thiol $\mathrm{pK}_{\mathrm{a}}$. Thus, aromatic thiols are better leaving group than glutathione as aromatic thiols have lower thiol $\mathrm{pK}_{\mathrm{a}}$ values than glutathione. ${ }^{43}$ 
A
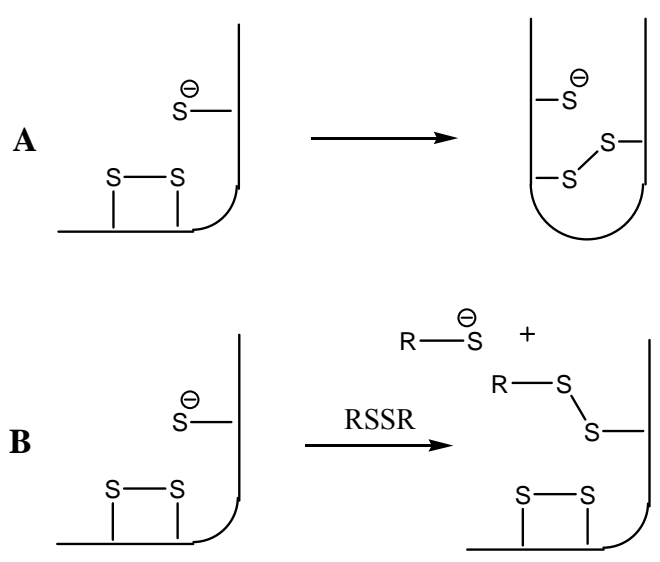

C
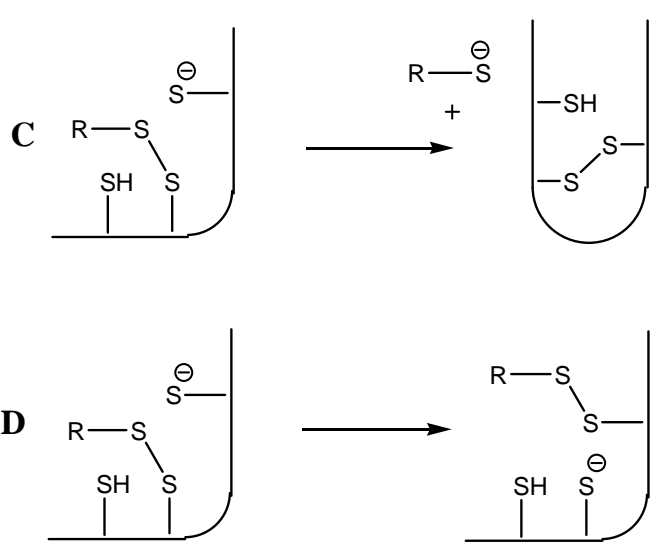
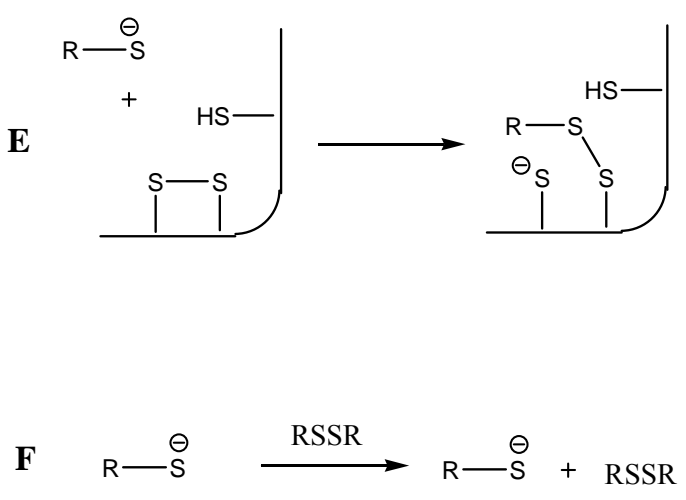

G
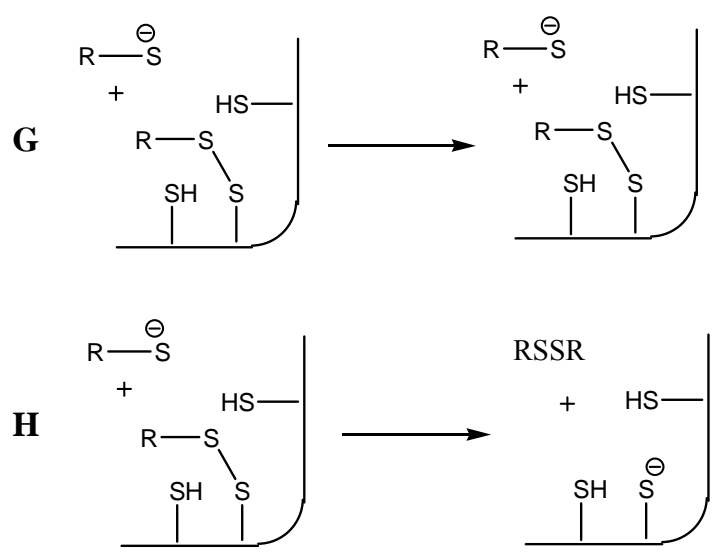

Figure 4. Thiol/disulfide interchange reactions with a small molecule thiol (RSH) and a small molecule disulfide (RSSR) that occur during in vitro protein folding. ${ }^{37}$

\subsubsection{Protein disulfide isomerase}

Protein disulfide isomerase (PDI), a $57 \mathrm{kDa}$ protein, is a member of a large family of dithiol/disulfide oxidoreductases, the thioredoxin superfamily. ${ }^{45}$ Protein disulfide isomerase is found in a number of living organisms, such as fungi, plants, and animals. ${ }^{46}$ Protein disulfide isomerase is constitutively expressed in many tissues and organs and retained in the lumen of the endoplasmic reticulum in high concentrations. In the endoplasmic reticulum, PDI catalyzes the formation, reduction, and isomerization of disulfide bonds in newly synthesized proteins. ${ }^{47}$ Additionally, PDI also shows chaperone activity, by preventing the aggregation of unfolded proteins, and is a member of two 
multimeric enzyme complexes, prolyl 4-hydroxylase and microsomal triglyceride transfer protein. ${ }^{48-50}$

\subsubsection{Structure of PDI}

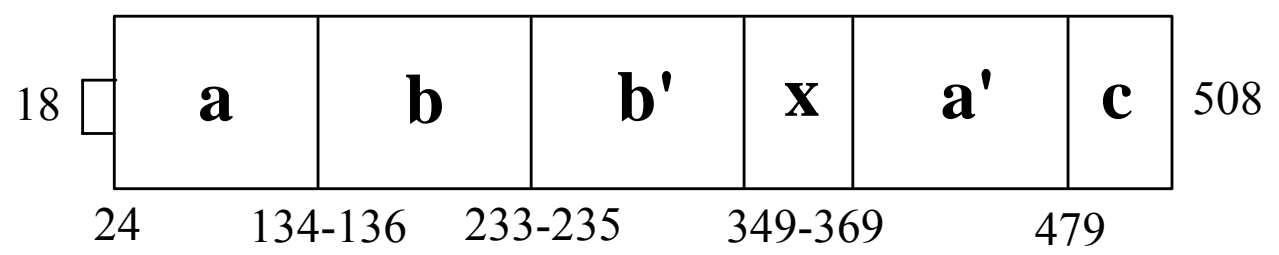

Figure 5. Domains of human PDI, numbering is for full length human PDI. ${ }^{51}$

Human PDI consists of 491 amino acids and has four distinct domains, a, b, b', and a', plus a highly acidic C-terminal extension c and a 19-amino acid interdomain linker between the b' and a' domains called $\mathbf{x}$ (Figure 5). ${ }^{51}$ The catalytic a and a' domains are homologous to thioredoxin, and each domain contains an independent active site. Each active site contains two cysteine molecules in the sequence Cys-Gly-His-Cys (CGHC), which mediates PDI's acitivities. ${ }^{52}$ The $\mathbf{b}$ and $\mathbf{b}$ domains are similar in sequence to each other but different from thioredoxin and redox inactive. The function of b' domain is to bind substrate proteins. ${ }^{53}$ The cationic c domain is not essential for enzymatic activity and ends with a C-terminal endoplasmic reticulum retention signal (KDEL in rat and human, HDEL in yeast). ${ }^{54,55}$ The crystal structure of human PDI is unknown, although structures of individual $\mathbf{a}$ and $\mathbf{b}$ domains of human PDI have been determined by NMR spectroscopy. ${ }^{56,57}$ These studies showed that not only the a domain but also the $\mathbf{b}$ domain adopts the thioredoxin fold. However, the three dimensional arrangement of the four thioredoxin domains and their respective functions in the catalytic mechanism are still unknown. 

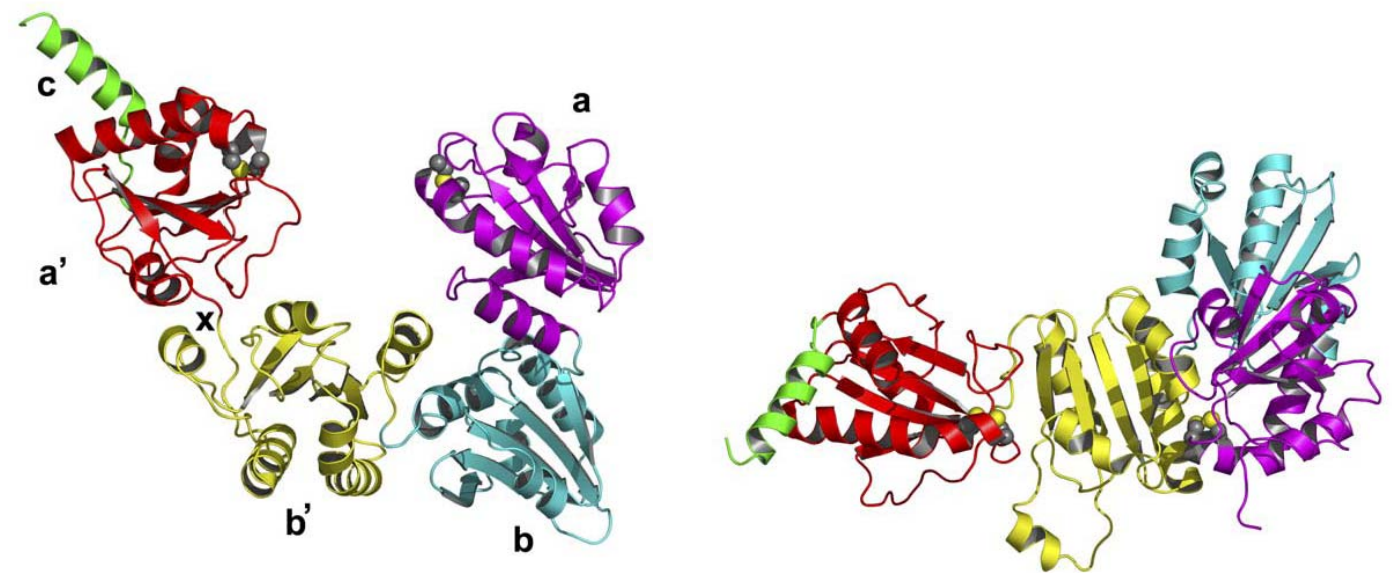

Figure 6. a, b, b', and a' domains of PDI are represented in magenta, cyan, yellow, and $\mathrm{red}$, respectively, and C-terminal extension is represented in green. The orientation of the two structures differ by a $90^{\circ}$ rotation around the horizontal axis. In the a and a' domains, the side chains of active site cysteines are revealed in space filling representation with the sulfur atoms in yellow color. Figure from Tian, G. et al., $2006 .^{58}$

Recently, Tian et al. have determined the crystal structure of full length yeast PDI at $2.4 \AA$ resolution, the first complete PDI structure. ${ }^{58}$ The crystal structure of PDI adopts the shape of the letter " $\mathrm{U}$ " although in twisted form. The a and a' domains lies on the end of the "U" and the b and b' domains form the base (Figure 6). The width and height of the molecule "U" is $\sim 80 \AA$ and $\sim 60 \AA$, respectively. According to the crystal structure, each of the domains, a, a', b, and b', adopts the thioredoxin fold with minor changes (Figure 7I). The prototypical thioredoxin fold consists of a five stranded $\beta$ sheet with two $\alpha$ helices on each side (Figure 7II).

In vivo, disulfide bond formation is catalyzed by PDI. Protein disulfide isomerase contains two cysteine thiol groups (two cysteine separated by two amino acids, CXXC) in each active site. One cysteine thiol is solvent exposed and the other thiol is buried. The solvent exposed thiol has a low $\mathrm{pK}_{\mathrm{a}}$ value, 6.7 , and is relatively reactive with disulfide bonds compared to small molecule aliphatic thiols, such as glutathione. The other thiol 
has a high thiol $\mathrm{pK}_{\mathrm{a}}$ value and is buried inside the protein. However, the use of PDI for in vitro folding of disulfide containing protein is limited because of its cost and low catalytic activity $\left(k_{\mathrm{cat}}=\sim 1 \mathrm{~min}^{-1}\right) .^{31}$
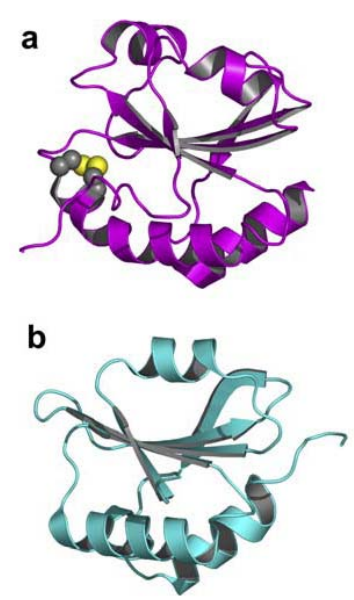

I
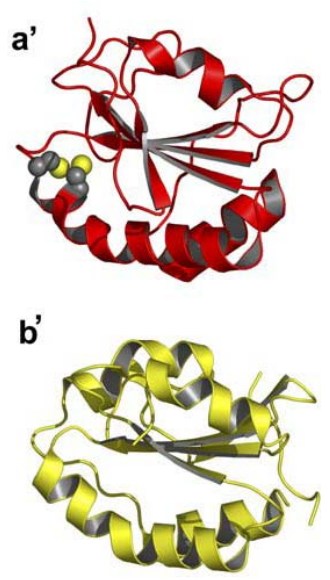

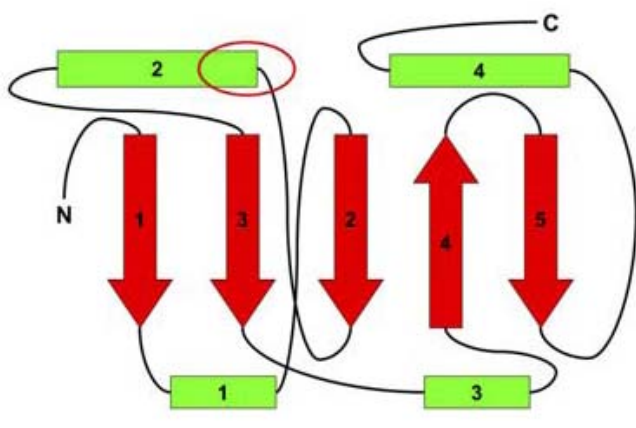

II

Figure 7. I) Structure of $\mathbf{a}, \mathbf{a}^{\prime}, \mathbf{b}$, and $\mathbf{b}^{\prime}$ domains of PDI. II) The typical thioredoxin fold, green represents $\alpha$ helices, red represents $\beta$ sheets, and red oval indicates the location of active site. Figure from Tian, G. et al., 2006. ${ }^{58}$

\subsubsection{Chaperone and anti-chaperone activity of PDI in the oxidative folding of lysozyme}

One of the most common problems faced in in vitro protein folding of lysozyme is aggregation, which results from the low solubility of the unfolded protein or folding intermediates. ${ }^{59}$ Aggregation is also a common phenomenon when disulfide containing proteins are overexpressed in vivo. The folding efficiency depends on how the unfolded denatured protein partitions between pathways leading to aggregation and pathways leading to native protein. In vivo, foldases and molecular chaperones influence the partitioning between productive and non-productive folding pathways. ${ }^{60}$ Foldases 
increase the folding rate by catalyzing the slow chemical steps such as disulfide formation and proline isomerization. ${ }^{61,62}$ Molecular chaperones do not appreciably increase the folding rate, but inhibit non-productive aggregation and misfolding by binding to non-native proteins. ${ }^{60,63}$ In order to inhibit aggregation, molecular chaperones must be present in stoichiometric excess as compared to the protein substrate, while foldases (e.g. PDI) can function at catalytic concentrations. When the functions of foldases and molecular chaperones become unbalanced, productive folding may be disturbed leading to protein aggregation and misfolding. Apart from its role as a foldases, PDI has two paradoxical roles in substrate aggregation. Protein disulfide isomerase can function as a chaperone and inhibit aggregation, or under some conditions, PDI behaves as an anti-chaperone and assist in the formation of aggregates.

Initially, during the folding of lysozyme, when PDI is present in substantial stoichiometric excess, PDI can prevent the formation of lysozyme aggregation, suggesting that very rapid disulfide formation can divert the denatured protein toward productive folding (Figure 8). ${ }^{48}$ Furthermore, one of the characteristic features of molecular chaperone involves the interaction of the chaperone's nonspecific peptidebinding site with a denatured protein in a manner which inhibits protein aggregation. A nonspecific peptide/protein binding site is present in PDI, which can act as a molecular chaperone at high PDI concentrations and inhibit lysozyme aggregation. ${ }^{64-66}$

In contrast, under certain conditions, PDI aids in the formation of protein aggregates, a behavior known as anti-chaperone activity. ${ }^{67,68}$ The anti-chaperone activity of PDI may be attributed to the interaction between PDI and lysozyme aggregates, which facilitates the intermolecular cross linking of additional lysozyme to the aggregate, even 
for molecules that were previously committed to folding (Figure 8). Intermolecular cross linked aggregates between PDI and unfolded protein is usually seen when low concentration of PDI is added to a solution of unfolded, reduced lysozyme ${ }^{67}$ Thus, PDI shows anti-chaperone like activity at low concentration and exhibits chaperone like activity at high concentration suggesting the rationale for PDI's high concentration in vivo and its low catalytic efficiency.

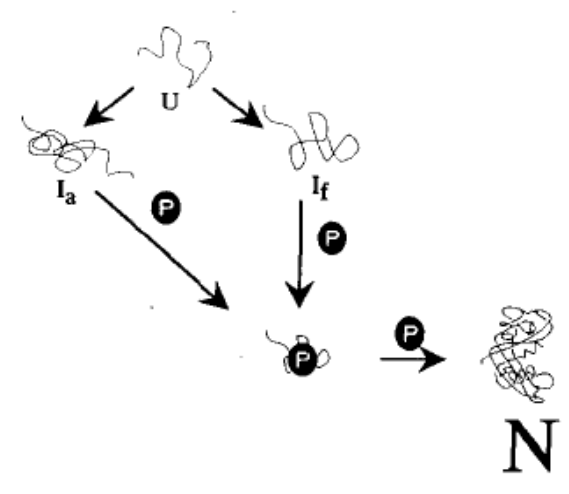

Chaperone

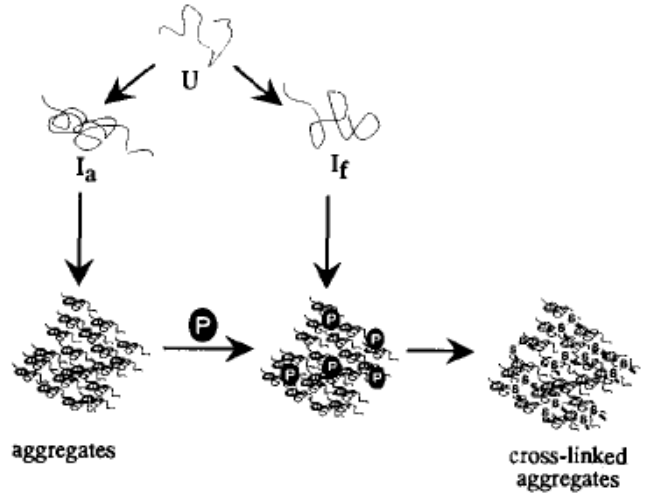

Anti-chaperone

Figure 8. Proposed model for the chaperone and anti-chaperone activity of PDI by Puig et al., $1994 .{ }^{48} \mathrm{U}$ indicates reduced, denatured lysozyme. $\mathrm{I}_{\mathrm{a}}$ and $\mathrm{I}_{\mathrm{f}}$ are denatured lysozyme that are committed to aggregation and folding, respectively. $\mathrm{N}$ denotes native lysozyme and P represents PDI. ${ }^{48}$

\subsubsection{Role of Ero1p and glutathione in oxidative protein folding}

Native disulfide bond formation is an essential step for the folding and stability of many secreted proteins. The first step of the process is the oxidation of protein thiols to form disulfide bonds, and the next step is the rearrangement of non-native disulfide bonds to native ones. ${ }^{40,69}$ In vitro, oxidative protein folding is spontaneous but slow, taking from hours to days. ${ }^{70}$ However, in vivo, oxidative protein folding is fast, which suggests that disulfide bond formation and rearrangement is catalyzed by enzymes in living cells. ${ }^{71}$ 
Protein disulfide bond formation in eukaryotic cells occurs in the lumen of the endoplasmic reticulum (ER). ${ }^{72}$ The ER contains millimolar concentrations of reduced glutathione (GSH) and oxidized glutathione (GSSG), although the exact concentrations of both are unknown. The ratio of [GSH]/[GSSG] in the ER ranges from 1:1 to 3:1, while in the cytosol, the ratio ranges from 30:1 to $100: 1{ }^{73}$ The high concentration of GSH in the cytosol disfavors the formation of protein disulfide bonds in the cytosol. On the contrary, the more oxidizing conditions in the ER compared to the cytosol thermodynamically favors the formation of protein disulfide bonds. The high concentration of GSSG in the ER has led to the proposal that GSSG provides the oxidizing equivalents that are required during protein disulfide bond formation in vivo. ${ }^{73}$

Over the past decade, the perception of the physiologically relevant mechanisms for PDI oxidation in vivo has changed. Prior to 1998, GSSG was thought to oxidize PDI in vivo, however, by the discovery and subsequent characterization of ER membrane associated protein, Erolp, this viewpoint has been changed. ${ }^{74}$ Now, it is believed that Erolp provides the oxidizing equivalents necessary for protein disulfide bond formation to PDI. ${ }^{74-76}$ While screening temperature sensitive Saccharomyces cervisiae mutants for conditional defects in export of secretory proteins from the ER in yeast, a novel gene named Ero1 was identified. ${ }^{74,75}$ Furthermore, Ero1p driven oxidation of PDI can occur independently of glutathione both in vivo and in vitro. ${ }^{74,77}$ Most importantly, Erolp and PDI form a mixed disulfide in vivo. ${ }^{78}$ In the ER lumen, flavin adenine dinucleotide (FAD) bound Erolp oxidizes PDI through a thiol/disulfide interchange reaction. In the absence of Erolp, PDI accumulates in its reduced form. ${ }^{77}$ Erolp is not the direct oxidant of 
folding proteins, but relies on PDI to transfer oxidizing equivalents. ${ }^{77}$ Thus the oxidizing equivalents are transferred via the protein relay: Ero1p to PDI to protein (Figure 9).

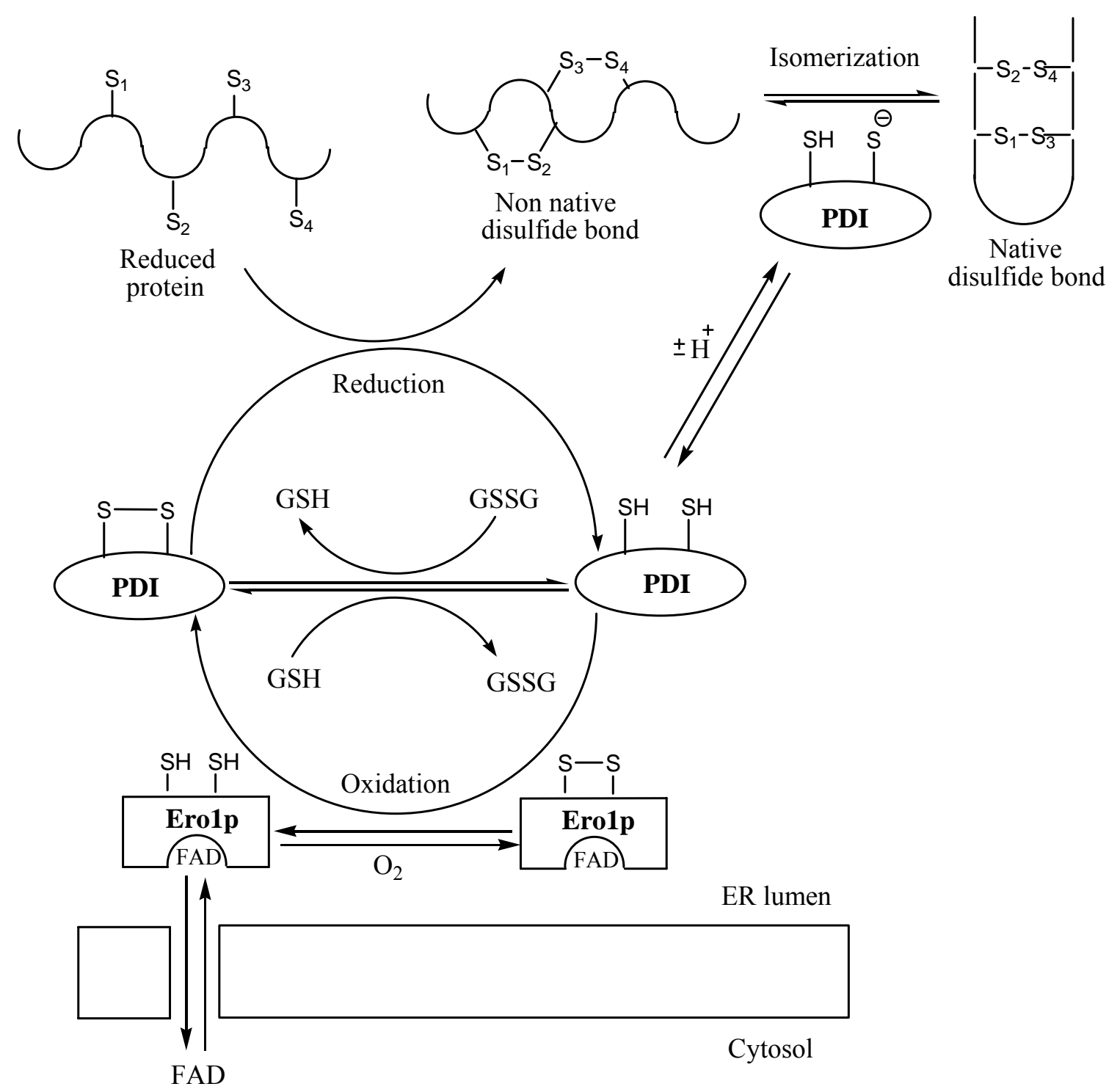

Figure 9. The pathway of native disulfide bond formation in the ER of the lumen by PDI via Ero1p.

Genetic evidence in yeast has shown that glutathione is not essential for disulfide bond formation, but that glutathione functions as a net reductant in the ER.$^{79}$ The role of glutathione as a reductant was evident from studies in which the synthesis of GSH was 
prevented. While screening suppressors of the temperature sensitivity of the ero1-1 mutant, a deletion of GSH1, the first enzyme in the biosynthesis of glutathione, was found to strongly suppress the ero1-1 phenotype. ${ }^{79}$ The absence of glutathione as a reductant resulted in less reduction of oxidized PDI and proteins, thus, allowing a compromised ero1-1 oxidation system to support growth of yeast. The oxidative protein folding of carboxypeptidase $\mathrm{Y}$ (CPY), a five disulfide bond containing protein, proceeds with normal kinetics in a $\Delta g s h 1$ strain but is sensitive to oxidative stress, consistent with the role of glutathione as a net reductant. ${ }^{79}$ Additionally, two more studies have shown that glutathione has a crucial role in the isomerization of non-native disulfide bonds. ${ }^{80,81}$ These studies showed that when the glutathione level in the ER decreases, disulfide bond formation increases. However, the increase in the disulfide bond formation is accompanied by an increase in non-native disulfide bond formation. Furthermore, a decrease in the levels of cytosolic GSH results in PDI becoming more oxidized, limiting the ability of PDI to isomerizes non-native disulfide bonds. Thus, it suggests that, directly or indirectly, GSH is involved in the isomerization of non-native disulfides. ${ }^{82}$

\subsubsection{General pathway of protein folding}

Numerous folding studies on model proteins, such as ribonuclease A (RNase A), have been conducted to understand the mechanism of protein folding. Some proteins fold directly without any intermediate, while others fold via one or more folding intermediates. Four general types of protein folding pathways via intermediates were proposed by Scheraga et al. (Figure 10) on the basis of oxidative protein folding studies with RNase A. ${ }^{41}$ Terminology used to describe the covalent structure of disulfide 


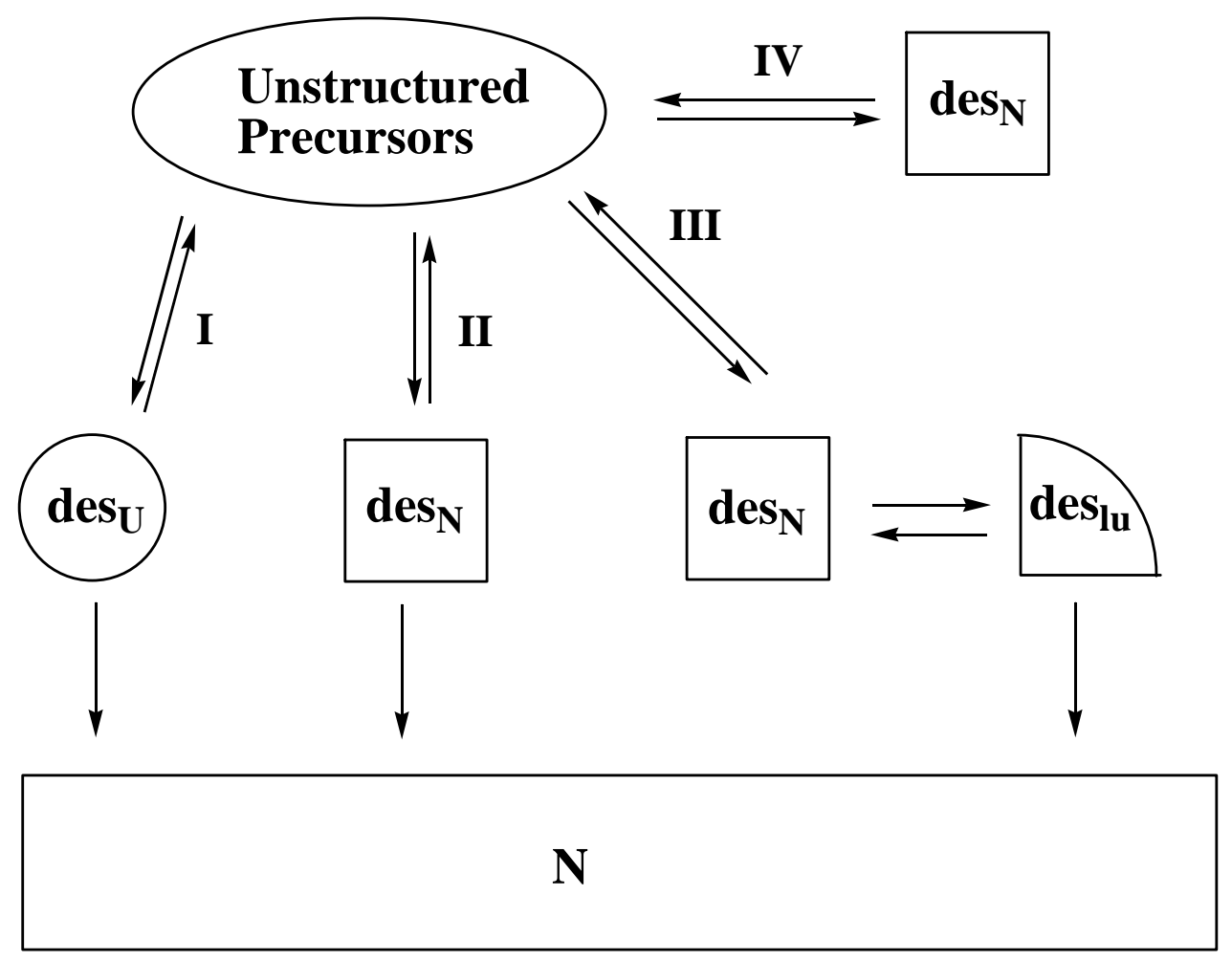

Figure 10. Generic folding pathways for oxidative folding of a typical disulfide containing protein as proposed by Scheraga et al., $2000{ }^{41}$

intermediates is as follows: A disulfide species refers to a protein with a specific pairing of cysteines in its disulfide bonds, whereas a disulfide ensemble is any collection of disulfide species. A des species is where the protein is missing only one native disulfide bond, for example, the des[65-72] species of RNase A has three native disulfide bonds, but lacks the 65-72 disulfide bond. The intermediates in the pathways are classified into two groups, "unstructured precursor" where the protein has random disulfide bonds, and "des species". It was assumed that only intermediates which have native-like structure, such as des species are capable of folding to a native like structure (indicated by "N" subscript). The "U" and "lu" subscripts represent that the corresponding species are unfolded or locally unfolded, respectively. 
Pathway I is the simplest oxidative folding pathway, as it has no structured intermediates. The native protein $\mathrm{N}$ regenerates directly from an unfolded precursor $\operatorname{des}_{U}$. In pathway II, folded intermediate $d e s_{N}$ is formed and is not metastable; $d e s_{N}$ then is oxidized directly to the native state. Pathway III involves the formation of a folded intermediate $d e s_{N}$ which is metastable; $d e s_{N}$ preferentially oxidizes to the native protein. The metastable intermediate must first undergo a local unfolding step des lu before oxidizing to the native state. Pathway IV involves the formation of a folded metastable species $\operatorname{des}_{N}$ which preferentially reshuffles rather than being oxidized to the native protein. Pathway IV is referred to a metastable dead end pathway. The rate determining steps for pathways I and II are the formation of the structured species, while that for pathway IV is the conformational unfolding of the metastable species. Pathway III is intermediate between pathway II and IV; the rate determining step may be either the formation of the structured intermediate or the local unfolding of the structured intermediate, depending on the folding conditions.

\subsubsection{Hen egg white lysozyme (HEWL)}

\subsubsection{General information}

Lysozyme, an enzyme present in tears, mucus, other body secretions, and egg whites, catalyzes the hydrolysis of the $\beta(1-4)$ glycosidic linkage between $N$ acetylmuramic acid (NAM) and $N$-acetylglucosamine (NAG). ${ }^{1}$ Lysozyme functions as a bactericidal agent or helps to dispose the bacteria after they have been killed by other means. ${ }^{1}$ Lysozyme has been widely studied and is one of the most mechanistically well characterized enzymes. In 1922, Alexander Fleming discovered lysozyme by accident in his laboratory. Nasal mucus was dripped into a Petri dish with bacterial cultures by 
accident, and cells were lysed. He carefully observed this phenomenon and determined the substance responsible for the lysis of the bacteria. Fleming discovered that the antibacterial substance was an enzyme and he named it lysozyme, lyso- means capacity to lyse bacteria and zyme- as it is an enzyme. The X-ray structure of HEWL was elucidated by David Phillips in 1965 . The three dimensional structure revealed that lysozyme is roughly ellipsoidal in shape with the dimensions of 30 x 30 x $45 \AA$.

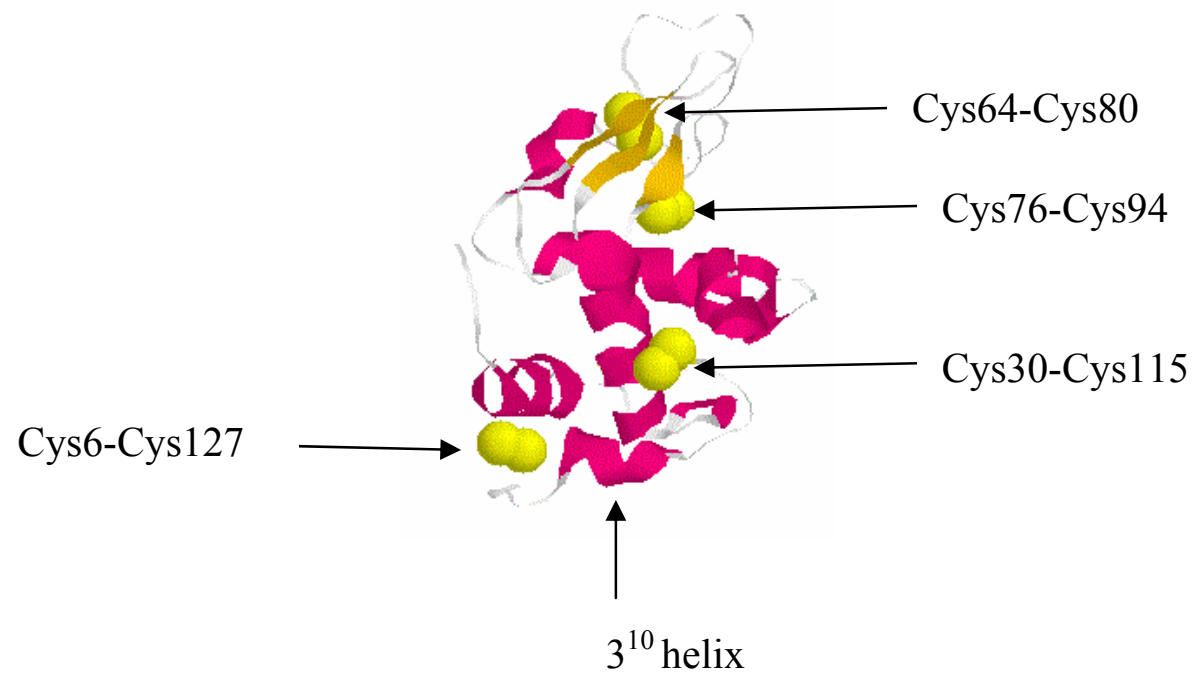

Figure 11. Rasmol representation of native hen egg white lysozyme. ${ }^{42}$ (PDB id: $3 \mathrm{~A} 8 \mathrm{Z}$ )

Lysozyme is a monomeric protein of $14.6 \mathrm{kDa}$ containing 129 amino acids and eight cysteine residues forming four disulfide bonds. The four disulfide bonds occur between residues Cys6-Cys127, Cys30-Cys115, Cys64-Cys80, and Cys76-Cys94 and provide stability to the native structure of lysozyme. ${ }^{42}$ The disulfide bonds in native lysozyme are denoted as [6-127], [30-115], [64-80], and [76-94]. Lysozyme is made up of two domains, one consisting of four $\alpha$-helices and a C-terminal $3_{10}$ helix (called the $\alpha$ domain), and one consisting of a triple-stranded antiparallel $\beta$-sheet, a $3_{10}$ helix, and a 
long loop (called as the $\beta$-domain). ${ }^{83}$ Additionally, a short double stranded antiparallel $\beta$ sheet and one of the four disulfide bonds [76-94] link the two domains. ${ }^{83}$ Two disulfide bonds [6-127] and [30-115] are present within the $\alpha$-domain, and the remaining disulfide bond [64-80] is located within the $\beta$-domain (Figure 11). ${ }^{42}$

\subsubsection{Distributions of conformers during lysozyme folding}

Identification of intermediates formed during oxidative folding provides information

about the distributions of disulfide species as folding progress. ${ }^{84}$ As the number of cysteine residues increases in a protein, the probability of forming incorrect disulfide bonds increases. The folding of lysozyme can occur in various steps, each of which involves oxidation of thiols and thiol/disulfide interchange reactions (Figure 12) ${ }^{85}$ In the first oxidation step, species with one disulfide bond and six thiol groups are formed. There is the possibility of 28 such species, but only four of them have a native disulfide bond. In the second step, intermediates containing two disulfide bonds and four thiol groups are formed. Of the 210 possible two disulfide bond containing intermediates, only six have both disulfide bonds correctly paired. In the third step, intermediates with three disulfide bonds and two thiol groups are formed. Of the 420 possible structures, only four have native sets of disulfide bonds. In the fully oxidized state, there are four disulfide bonds, and of the 105 possible isomeric forms, only one has a native set of disulfide pairing. On the other hand, when we consider mixed protein-GSH disulfide bonds, the total number of possible intermediates increases to over 7000 . However, during the later stages of folding, only a small fraction of possible three- and four-disulfide intermediates accumulate to significant levels. In fact, only 3 three-disulfide bonds containing 
intermediates with native disulfide bonds, and 1 four-disulfide bonded species, the native protein, have been identified. ${ }^{42}$

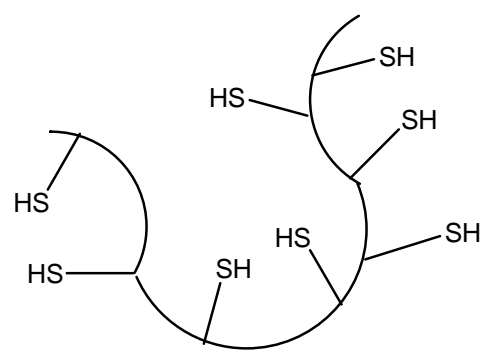

Reduced Lysozyme
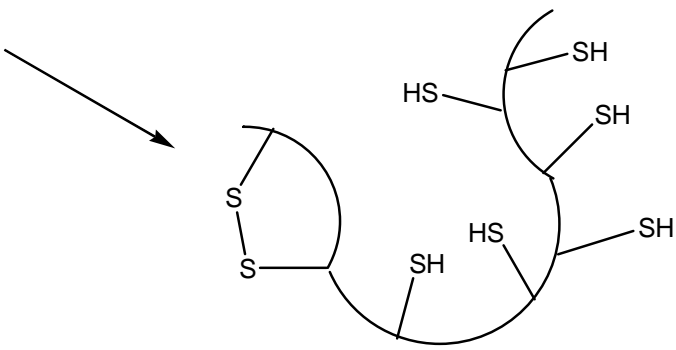

One-disulfide intermediates (28 isomers are possible, but only four
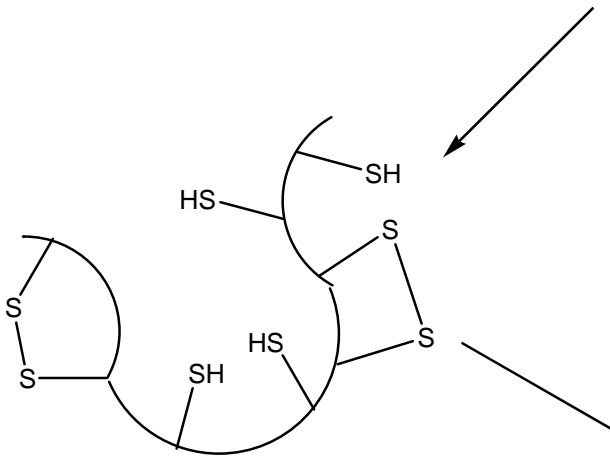
species possess native disulfide bonds)

Two-disulfide intermediates

(210 isomers are possible, but only six species possess native disulfide bonds)
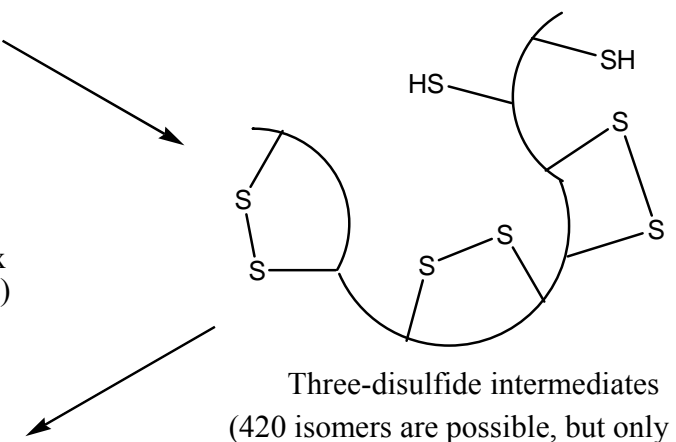

Three-disulfide intermediates (420 isomers are possible, but only four species possess native disulfide bonds)

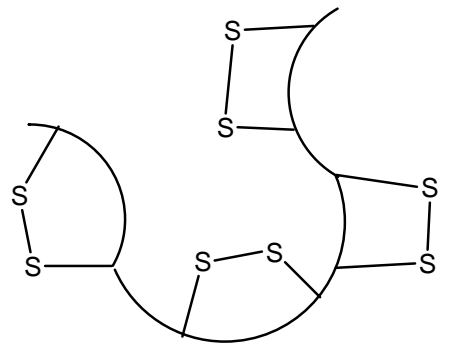

Native lysozyme with four disulfide bonds

(105 isomers are possible, but only one species possess native disulfide bonds)

Figure 12. Schematic diagram of possible disulfide intermediates during the folding of reduced lysozyme. $^{85}$ 


\subsubsection{Refolding kinetics of the three-disulfide intermediates}

Dobson et al. described the oxidative folding of lysozyme in terms of the disulfide bonded intermediates that accumulated. An acid quenched method along with reverse phase HPLC at pH 2.0 was used to separate the intermediates. ${ }^{42}$ The oxidative protein folding was carried out at $\mathrm{pH}$ 8.5. The elution profile showed that native-like threedisulfide species occurred during the later stages of folding. The most abundant intermediate was des [76-94], a highly native-like species, which has three native disulfide bonds but lacks the Cys76-Cys94 disulfide bond. Two minor intermediates were also observed, des [6-127] and des [64-80], which have native-like structure and threenative disulfide bonds. ${ }^{86}$ Figure 13 illustrates the disappearance of the fully reduced protein $(\mathrm{R})$ and the appearance of the three-disulfide intermediates and native protein (N). ${ }^{42}$ The results revealed that des [76-94] was the most abundant folding intermediate and accounted for $40 \%$ of the total protein at one stage. Later in folding, des [76-94] and native protein were the only species populated at significant levels. Although des [76-94] has a highly native-like structure with essentially native optical properties, its enzymatic activity is significantly lower $(50 \pm 5 \%)$ than that for native protein. ${ }^{86}$ Furthermore, they observed two other three-disulfide intermediates, des [64-80] and des [6-127]. Des [6480] accumulated to lower levels (10-15\%) and oxidized more quickly than des [76-94], whereas des [6-127] was present at even lower levels ( 5\%). Since des [76-94] dominated the later stages of the folding reaction, it was suggested that the conversion of des [76-94] to native protein is likely the rate limiting step in the folding of the majority of lysozyme molecules. However, the kinetic profile of des [76-94] revealed that its conversion to native protein is a very slow process with a time constant of several hours and consistent 


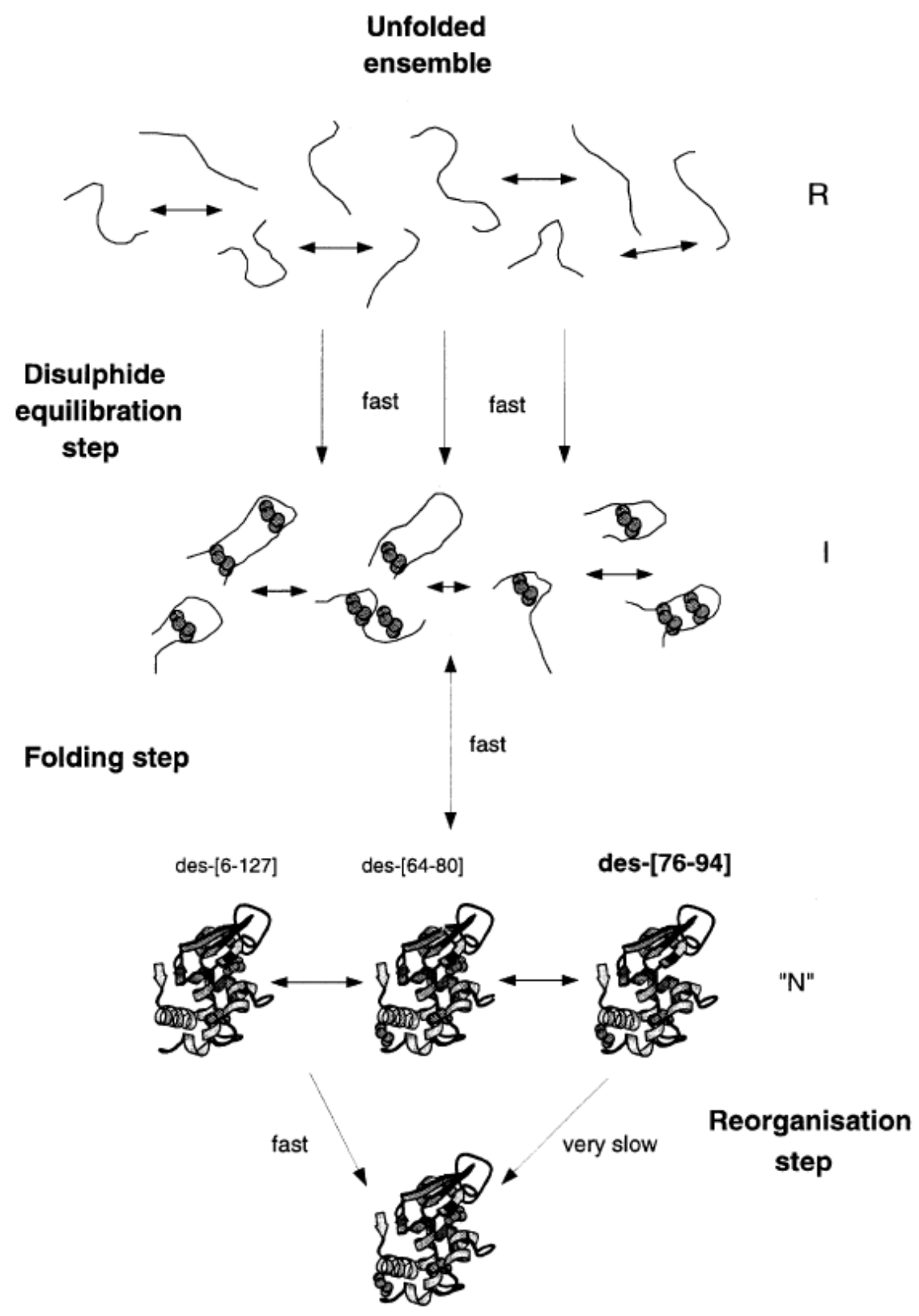

$\mathrm{N}$

Figure 13. Schematic diagram of the oxidative refolding of lysozyme, showing the statistical nature and observed kinetics of protein folding. $\mathrm{R}$ represents fully reduced protein, I corresponds to ensemble of early unstructured intermediates, "N" indicates native-like three-disulfide intermediates, and $\mathrm{N}$ represents fully native protein. Figure from Van den Berg, B. et al, 1999. ${ }^{42}$ 
with the slow phase in the recovery of the enzymatic activity. Thus, it cannot account for the presence of $\sim 35 \%$ native protein after only 60 min of folding and clearly indicates that $\sim 25-30 \%$ of lysozyme molecules do not form the native state via des [76-94]. These $\sim 25-30 \%$ of lysozyme molecules could fold via the minor intermediates des [6-127] and des [64-80], which are converted more rapidly to native protein than des [76-94]. Therefore, des [76-94] appears to act as a kinetic trap.

To support the hypothesis that des [76-94] is a kinetic trap, Dobson et al. carried out the refolding of purified des [76-94] to native protein at $\mathrm{pH} 8.5$ in refolding buffers containing 1 or $4 \mathrm{M}$ urea. ${ }^{42}$ They found that des [76-94] was converted to native protein 3 times faster in $4 \mathrm{M}$ urea than in $1 \mathrm{M}$ urea and the results suggested that des [76-94] needed to unfold in order to form the final Cys76-Cys94 disulfide bond and generate native protein. Additionally, in another experiment at $\mathrm{pH} 7.4$, des [76-94] was allowed to refold in the presence or absence of PDI, buffer containing $1 \mathrm{M}$ urea, and $2 \mathrm{mM} / 0.4 \mathrm{mM}$ GSH/GSSG. They found that the refolding rate of des [76-94] to native protein was $\sim 8$ times faster in the presence of PDI than in the absence of PDI. Furthermore, the data for mutant human lysozyme also suggested that the thiol group of Cys76 in des [76-94] is solvent exposed, whereas that of Cys94 is buried and not accessible to GSSG or a protein disulfide. ${ }^{87,88}$ The fact that Cys76 is solvent exposed and Cys94 is buried in des [76-94] may be the reason for the slow conversion of des [76-94] to fully native state in the absence of PDI or high concentrations of urea. ${ }^{86}$ 


\subsubsection{Bovine pancreatic trypsin inhibitor (BPTI)}

\subsubsection{General information}

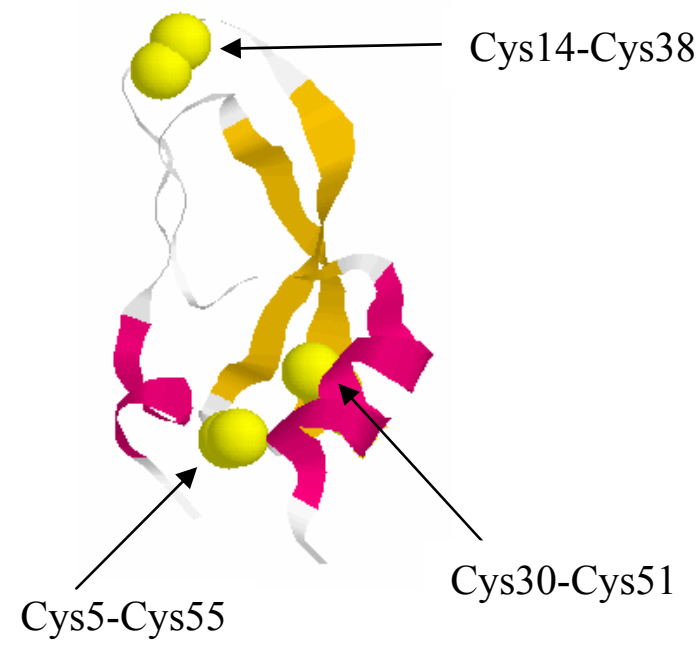

Figure 14. Rasmol representation of bovine pancreatic trypsin inhibitor. ${ }^{89}$ (PDB id: 1PIT)

To understand the oxidative folding pathways of disulfide containing proteins BPTI has been used extensively as a textbook example. BPTI is a monomeric polypeptide containing 58 amino acid residues, and its native state has two $\alpha$-helices and two antiparallel $\beta$-sheets. Three disulfide bonds between cysteine residues $14-38,30-51$, and 5-55 stabilize the native state of BPTI (Figure 14).

The protein unfolds when the three disulfide bonds in BPTI are reduced. The reduced protein can then be refolded by treating it with an oxidizing agent. Various folding studies of BPTI has been carried out using oxidized glutathione and reduced glutathione or oxidized and reduced DTT. ${ }^{40,91}$ During folding of BPTI, the intermediates formed can be trapped and isolated. The folding pathway of BPTI is described by the formation of several one-disulfide and two-disulfide intermediates. ${ }^{92}$ The one- disulfide 
intermediate having a disulfide bond between cysteine 30 and cysteine 51 is denoted as [30-51] and is a native-like intermediate. Other one-disulfide intermediates seen during folding are [14-38] and [5-55]. Several two disulfide bond containing intermediates are also detected during folding [30-51;14-38], [5-55;14-38], and [30-51; 5-55] (Figure 15). ${ }^{90}$ Some intermediates with disulfide bonds that are not contained in native protein are also detected during the folding process, and these intermediates are called non-native intermediates. for e.g. [30-51; 5-14] and [30-51; 5-38].

a)

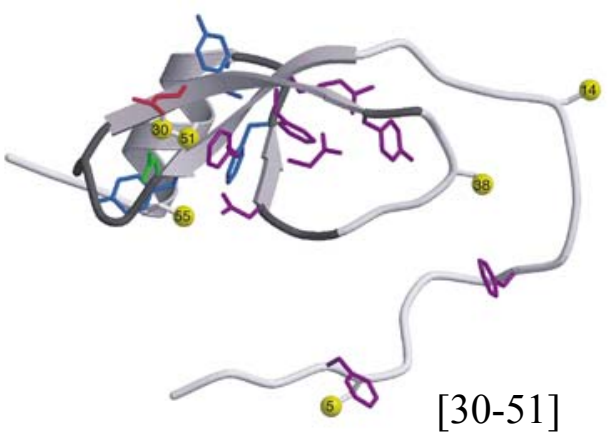

b)

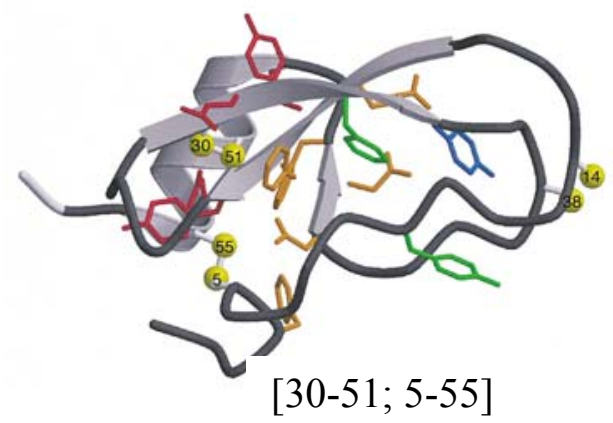

c)

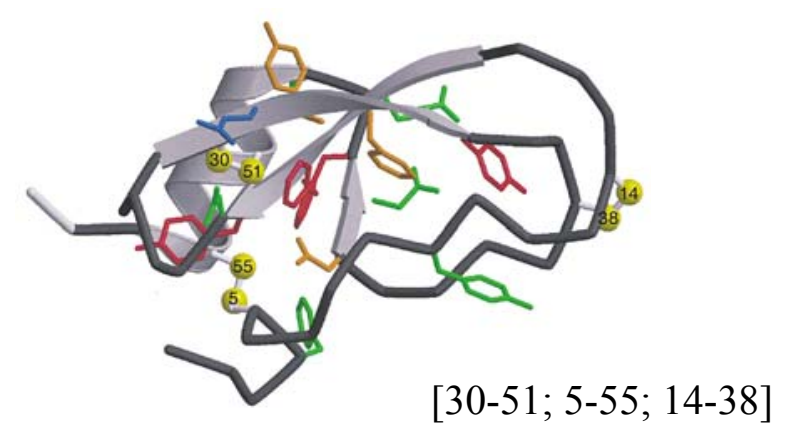

Figure 15. Folding pathway of BPTI with a) one disulfide intermediate, b) two disulfide intermediate, and c) native protein. Figure from Bulaj, G. et al., 2001. ${ }^{90}$

\subsubsection{Folding pathway of BPTI as proposed by Kim et al. ${ }^{40}$}

The oxidative folding pathway of BPTI is well characterized and has been studied for four decades by various research groups. ${ }^{40,93-97}$ The pathway has been described by the 
disulfide bonded intermediates that are formed during the oxidative folding. ${ }^{40,93,98-100} \mathrm{Kim}$ et al. proposed the folding pathway of BPTI by trapping intermediates with acid (Figure 16). ${ }^{40}$ Only six well populated disulfide species were seen and none of them contained non-native disulfide bonds. Reduced BPTI denoted by $\mathrm{R}$ is oxidized rapidly to onedisulfide intermediate [30-51] or [5-55]. Both intermediates are thought to have nativelike structure. The thiols of cysteine 14 and cysteine 38 are solvent exposed in these one-

Productive pathway

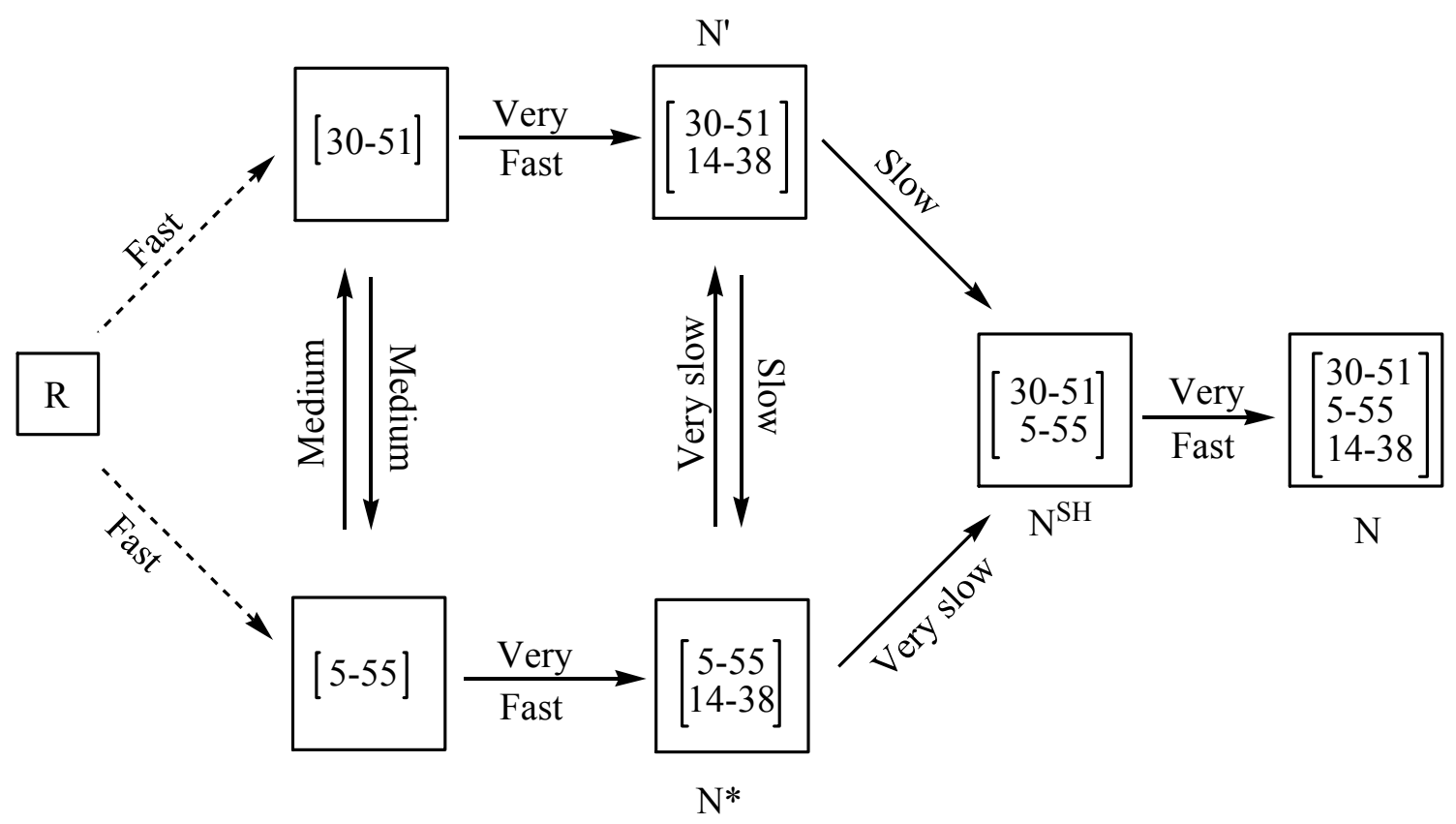

Non-productive pathway

Figure 16. Schematic representation of folding pathway of BPTI, where $\mathrm{N}$ is native protein and $\mathrm{R}$ is reduced protein as represented by Kim et al. ${ }^{40}$

disulfide intermediates and can form the 14-38 disulfide bond readily to give [30-51; 14 38], $\mathrm{N}^{\prime}$, and [5-55; 14-38], $\mathrm{N}^{*}$. Both $\mathrm{N}^{\prime}$ and $\mathrm{N}^{*}$ possess native-like structure and serve as kinetic traps for folding. The $\mathrm{N}^{*}$ is very stable and does not undergo further rearrangement, whereas $\mathrm{N}^{\prime}$ does rearrange slowly to form either [30-51;5-55], $\mathrm{N}^{\mathrm{SH}}$, or 
$\mathrm{N}^{*} . \mathrm{N}^{\mathrm{SH}}$ can then rapidly oxidized to native protein $(\mathrm{N})$. Under suitable oxidizing conditions, half of the molecules form native BPTI via N', called the productive pathway, while the other half are kinetically trapped in the form of $\mathrm{N}^{*}$, called the non-productive pathway. The free thiols in $\mathrm{N}^{*}$ are buried and inaccessible to oxidizing agents and thus $\mathrm{N}^{*}$ is kinetically stable.

\subsection{Oxidative protein folding}

\subsubsection{In vitro protein folding}

Industrially, the formation of inclusion bodies or aggregates is a serious problem for the production of disulfide containing proteins by recombinant DNA technology. In general, the lowest yielding step in the recovery of native protein from the aggregates is in vitro protein folding. ${ }^{101,41}$ The yield of in vitro protein folding is affected by many factors, such as composition of the redox buffer, the presence of folding aids, and the $\mathrm{pH}$

of the folding solution. ${ }^{41,101,102}$ Furthermore, it has been observed that the refolding yield decreases with an increase in the concentration of the protein. ${ }^{103,59}$ It has been shown that two types of interactions, intermolecular and intramolecular, compete during the refolding process. The intermolecular interaction is the cause for the decrease in yield as a function of the protein concentration..$^{59,104}$ The intramolecular interaction is a unimolecular process, and the rate of formation of renatured protein is independent of the protein concentration. Conversely, the intermolecular interaction is a second or higher order process, and as a result, the rate of aggregation increases with protein concentration. One of the ways to improve the refolding yield is to suppress the formation of aggregates. A simple method is to carry out protein refolding at very dilute 
concentrations (e.g. $<0.1 \mathrm{mg} / \mathrm{mL}$ ). However, large volumes of refolding solution are needed to carry out the refolding process, thereby increasing the production cost and time.

\subsubsection{Folding aids}

To date, a number of methods have been proposed to increase the refolding yield at moderate to high protein concentrations. One efficient strategy is the addition of folding aids. The most commonly used folding aids are guanidine hydrochloride, urea, arginine, and glycerol. ${ }^{18,27,105-109}$ Other additives include detergent and surfactants, polyethylene glycol, molecular chaperones, artificial chaperones, and several simple compounds, such as acetone, acetamide, sarcosine, and thiourea. ${ }^{106,110-115}$ Folding aids are proposed to increase the refolding yield by interfering with the intermolecular hydrophobic interactions. However, folding aids generally decrease the rate of folding. ${ }^{105-}$ ${ }^{107}$ Moreover, folding aids must be optimized for each protein, as folding aids have different effect on different proteins.

\subsubsection{Redox buffer}

Another technique to improve the yield of renatured protein in in vitro protein folding is the use of a redox buffer. A redox buffer is composed of a small molecule disulfide and/or a small molecule thiol. ${ }^{5,32,116}$ The most commonly used redox buffer contains oxidized glutathione (GSSG) and reduced glutathione (GSH). Numerous studies have been carried out using aliphatic thiol based redox buffers to fold inclusion bodies. Extensively studied aliphatic thiol based redox buffers include $\mathrm{GSH}\left(\mathrm{pK}_{\mathrm{a}}=8.7\right)$, dithiothreitol (DTT) $\left(\mathrm{pK}_{\mathrm{a}}=9.2\right)$, and $\beta$-mercaptoethanol $\left(\mathrm{pK}_{\mathrm{a}}=9.6\right)$. However, aliphatic thiol based redox buffers have low folding rates below $\mathrm{pH} 7.5$, as very little (less than 
$3 \%)$ of the aliphatic thiol is in the reactive thiolate form ( $\mathrm{pK}_{\mathrm{a}}$ approximately 9). Recently, improved redox buffers have been used, such as aliphatic dithiols, synthetic peptides, and aromatic monothiols. $^{32,34-38,116}$ Aliphatic dithiols, e.g. [( $( \pm)$-trans-1,2-bis(2-mercaptoactamido) cyclohexane (BMC)] with a thiol $\mathrm{pK}_{\mathrm{a}}$ of 8.3, and synthetic peptides can increase the overall yield. Raines et al. illustrated that the BMC increased the yield of native RNase A by two fold relative to its monothiol analog, $N$-methylmercaptoacetamide (NMA). The increase in yield was because of the presence of a second thiol group in BMC versus a single thiol group in NMA. Furthermore, Raines et al. showed that addition of BMC to $S$. cerevisiae growth medium increased the heterologous production of Schizosaccharomyces pombe acid phosphatase. However, BMC and synthetic peptides do not change the folding rate constant. Moreover, dithiols with a second thiol group have an advantage over monothiols (Figure 17). When dithiols or monothiols react with a protein disulfide bond, they produce a mixed disulfide bond. With the dithiols, but not monothiols, the second thiol group acts as a clock and provides a set amount of time for the protein to rearrange. If the protein does not rearrange, then the second thiol of the dithiol makes an intramolecular attack and disrupts the mixed disulfide bond. In the case of monothiols, there is no second thiol to act as a clock and the mixed disulfide can become kinetically trapped, and thus the overall yield of native protein decreases.

Furthermore, in previous studies by our group, it has been shown that aromatic monothiols $\left(\mathrm{pK}_{\mathrm{a}}\right.$ 5.5-6.6) increased the folding rate and the overall yield of native protein compared to standard aliphatic thiols $\left(\mathrm{pK}_{\mathrm{a}} 8.5-10\right)$. With aromatic monothiols, the folding rate of ribonuclease A was 10-23 times faster than with glutathione at $\mathrm{pH}$ 6.0, 7-12 times faster at $\mathrm{pH} 7.0$, and 5-8 times faster at $\mathrm{pH} 7.70 .{ }^{4,35,117}$ Additionally, it was also 


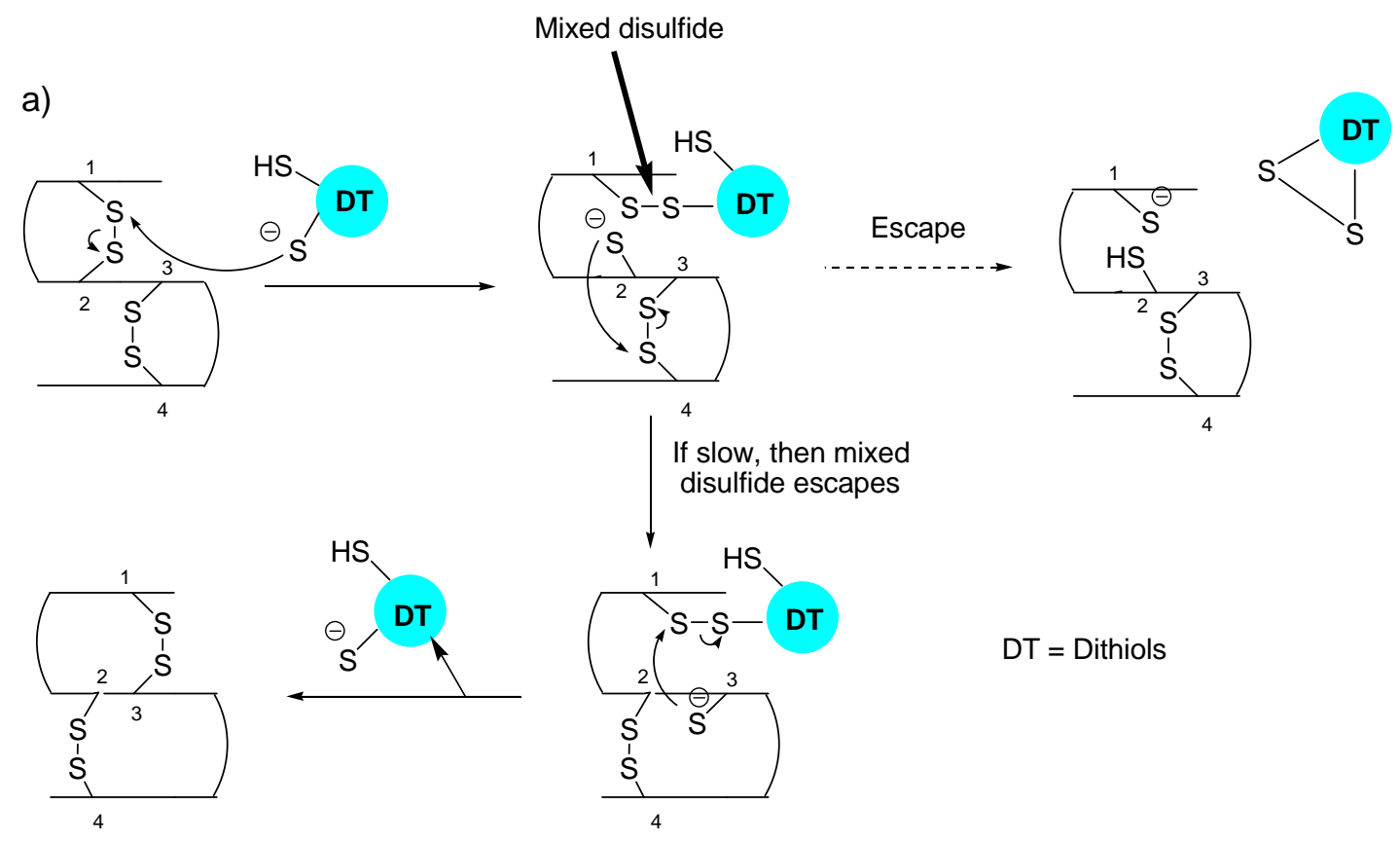

b)
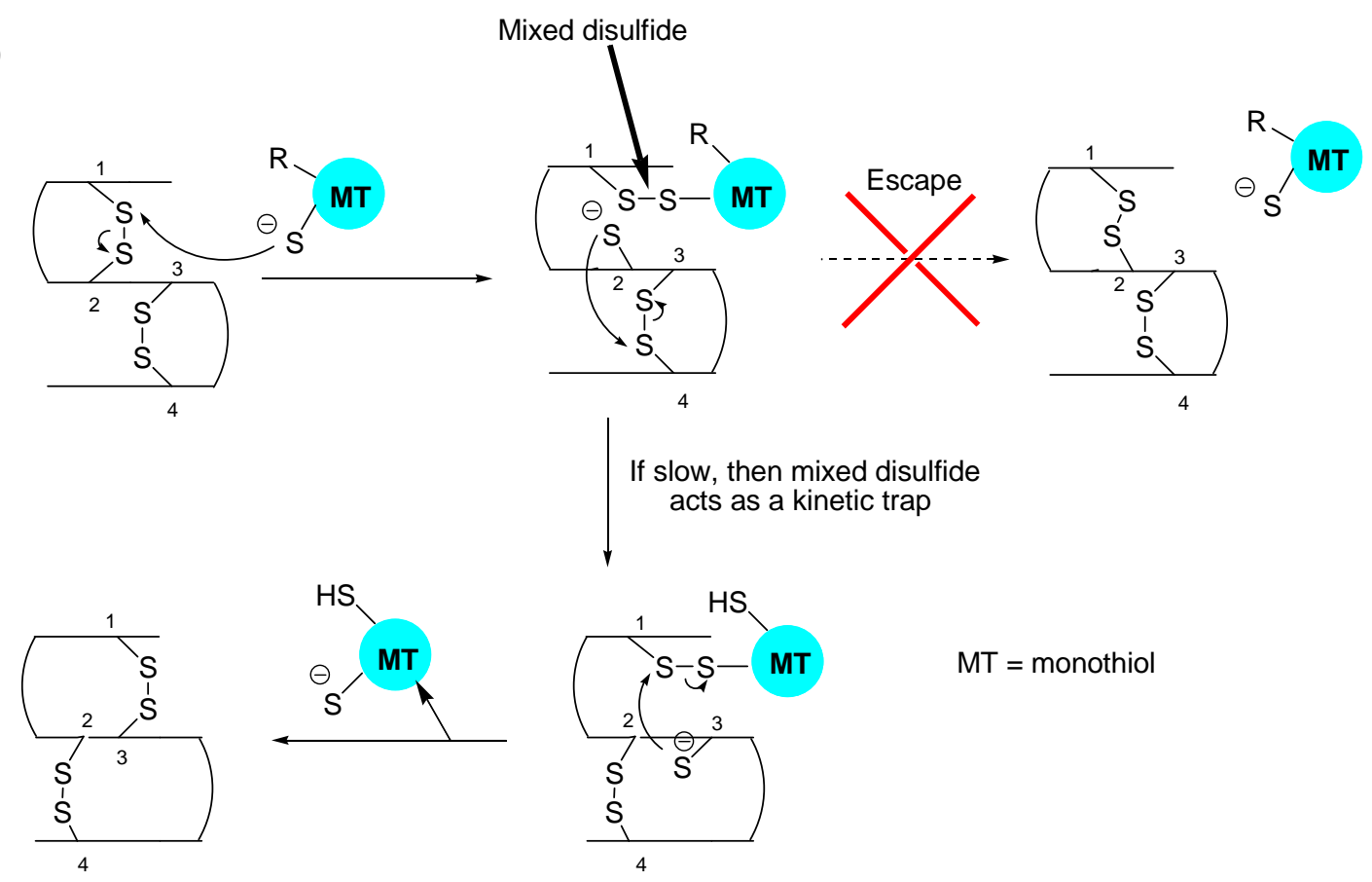

MT = monothiol

Figure 17. a) Thiol/disulfide interchange reaction with dithiols, such as PDI, showing escape mechanism. ${ }^{32}$ b) Thiol/disulfide interchange reaction with monothiol showing kinetic trap, as a mixed disulfide between monothiol and protein substrate. 
demonstrated that at a high protein concentration $(1 \mathrm{mg} / \mathrm{mL}$ of lysozyme), aromatic monothiols, 4-mercaptobenzylphosphonic acid (2) and quaternary ammonium salt (3) $\left(\mathrm{pK}_{\mathrm{a}}\right.$ 5.5-6), increased the folding rate and yield of lysozyme by 11 times and $20-40 \%$, respectively, at $\mathrm{pH} 7$, and by 7 times and $25 \%$, respectively, at $\mathrm{pH} 8$ in comparison with glutathione $\left(\mathrm{pK}_{\mathrm{a}}\right.$ 8.7) ${ }^{38}$ By combining the advantageous properties of aromatic monothiols and aliphatic dithiols, I proposed to design aromatic dithiols which will increase the protein folding rate and overall yield of native protein. 


\section{Chapter 2}

\section{Specific Aims}

Most pharmaceutically relevant proteins and many extracellular proteins contain disulfide bonds. ${ }^{4}$ Disulfide bonds between the correct cysteine residues are essential for the stability and activity of almost all disulfide-containing proteins. Because of progress in the field of biotechnology, proteins can now be overexpressed in bacterial cells. During overexpression, bacteria produce large quantities of high value protein in a rapid and inexpensive way. However, overexpressed proteins, especially disulfide-containing ones, are frequently deposited as insoluble aggregates inside the bacterium, called inclusion bodies. ${ }^{101}$ The protein within the aggregates is inactive and non-native. To obtain native protein, it is necessary to isolate and resolubilize the aggregates, and then fold the resulting protein in vitro. ${ }^{16}$ The formation of the correct disulfide bonds during in vitro protein folding is the slowest. In vitro protein folding is aided by the addition of a redox buffer, which is composed of a small molecule disulfide and/or a small molecule thiol. ${ }^{5}$ The most commonly used redox buffer contains reduced glutathione (GSH) and oxidized glutathione (GSSG). Many in vitro protein folding studies have been carried out using aliphatic thiol based redox buffers. Examples of aliphatic thiol based redox buffers include dithiothreitol $\left(\mathrm{pK}_{\mathrm{a}}\right.$ 9.2), glutathione $\left(\mathrm{pK}_{\mathrm{a}}\right.$ 8.7), $\beta$-mercaptoethanol $\left(\mathrm{pK}_{\mathrm{a}} 9.6\right)$, and cysteine $\left(\mathrm{pK}_{\mathrm{a}}\right.$ 8.3). Recently, more improved redox buffers have been employed, such as aliphatic dithiols, synthetic peptides, and some aromatic monothiols. Aliphatic dithiols, e.g., ( \pm )-trans-1,2-bis(2-mercapto-actamido)cyclohexane (BMC) and synthetic peptides have been shown to improve the overall yield of native protein as compared to standard 
aliphatic thiols $\left(\mathrm{pK}_{\mathrm{a}} 8.5\right.$ - 10) such as glutathione. ${ }^{32}$ Dithiols were designed on the basis of the in vivo protein folding catalyst, protein disulfide isomerase (PDI), which has two thiols in each active site. Furthermore, aromatic monothiols $\left(\mathrm{pK}_{\mathrm{a}} 5.5-6.6\right)$ have been demonstrated to increase the folding rate of lysozyme and RNase A in comparison with traditionally used aliphatic thiols such as glutathione. ${ }^{4}$ By combining the beneficial properties of aliphatic dithiols and aromatic monothiols, I propose to design aromatic dithiols that will increase the in vitro protein folding rates and overall yields of the disulfide containing proteins.

1) To synthesize the following aromatic monothiols and their disulfides on a multigram scale for the folding of lysozyme and bovine pancreatic trypsin inhibitor.

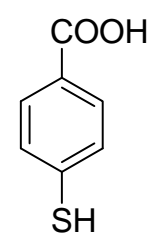

1<smiles>[R][S-]c1ccc(C(=O)O)cc1</smiles>

5<smiles>O=P(O)(O)Cc1ccc(S)cc1</smiles>

2

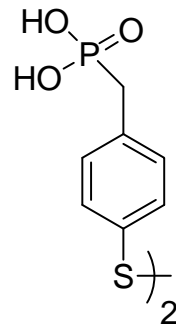

6

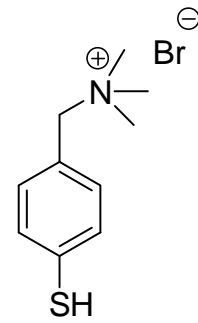

3

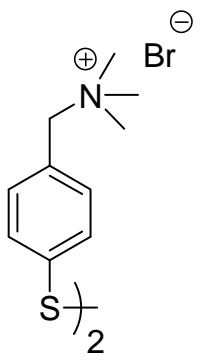

7<smiles>O=S(=O)(O)c1ccc(S)cc1</smiles>

4<smiles>[Z][S-]c1ccc(S(=O)(=O)O[Na])cc1</smiles>

8

2) To synthesize two series of aromatic ethylene glycol dithiols and determine their ability to enhance the in vitro folding rates and yields of lysozyme. 


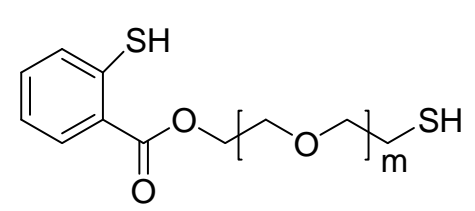

$m=0,1,2,3$

$9,10,11,12$

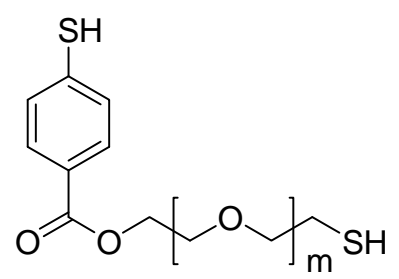

$m=1,2,3$

$13,14,15$

3) To synthesize aromatic quaternary ammonium salt dithiols and use them for the folding of lysozyme at high protein concentration $(1 \mathrm{mg} / \mathrm{mL})$.

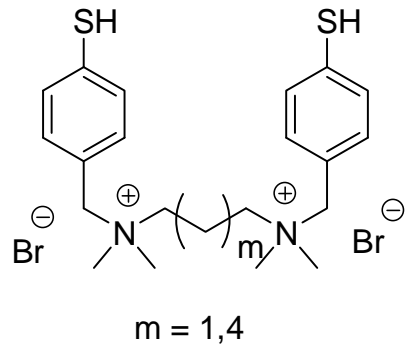

16,17 


\section{Chapter 3}

\section{Materials and general methods}

Hen egg white lysozyme was purchased from Roche Applied Sciences and used without further purification. Bis tris propane, Tris, sodium ethylenediaminetetraacetate (EDTA), dithiothreitol (DTT), Micrococcus Isyodeikticus, guanidine hydrochloride (Gdn $\mathrm{HCl}$ ), and the reduced and oxidized forms of glutathione (GSH and GSSG, respectively) were purchased from Sigma. Sephadex G-25 was purchased from GE Healthcare. The reagents used to synthesize ortho-substituted aromatic mono-, di-, tri-, and tetraethylene glycol dithiols $(\mathbf{9}, \mathbf{1 0}, \mathbf{1 1}$, and 12) and para-substituted aromatic di-, tri-, and tetraethylene glycol dithiols $(\mathbf{1 3}, \mathbf{1 4}$, and 15) were purchased from Aldrich. The $p$ mercaptobenzoic acid (1) and its disulfide (5) were synthesized as described previously. ${ }^{43,118}{ }^{1} \mathrm{H}$ NMR spectra were referenced to TMS at $0.00 \mathrm{ppm} .{ }^{13} \mathrm{C}$ NMR spectra were referenced to $77.00 \mathrm{ppm}\left(\mathrm{CDCl}_{3}\right)$ or $49.00 \mathrm{ppm}\left(\mathrm{CD}_{3} \mathrm{OD}\right)$. Elemental analyses were performed by Galbraith Laboratories, Inc., Knoxville, TN. High resolution mass spectroscopy (HRMS) was conducted by Florida State University, Tallahassee, FL.

\subsection{Synthesis of aromatic monothiols and their corresponding disulfides (1-8)}

\subsubsection{Synthesis of 4-mercaptobenzoic acid (1) $)^{43,119}$}

\subsubsection{Synthesis of methyl 4-(dimethylcarbamothioyloxy)benzoate (20)}

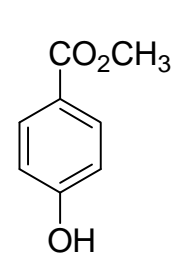

18

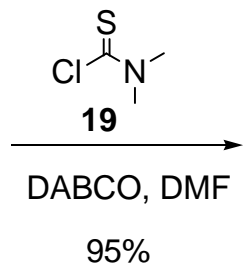

$95 \%$<smiles>CC(=O)c1ccc(OC(=S)N(C)C)cc1</smiles>

20 
Methyl 4-hydroxybenzoate (18) (38.75 g, $0.254 \mathrm{~mol})$ and 1,4-diazabicylco [2.2.2] octane $(\mathrm{DABCO})(80.0 \mathrm{~g}, 0.713 \mathrm{~mol})$ were dissolved in $300 \mathrm{~mL}$ of DMF. After all of the solid had been dissolved, N,N-dimethylthiocarbamoylchloride (19) (42.0 g, 0.339 mol) was added to the solution. The solution was stirred for $1.5 \mathrm{~h}$ at $65{ }^{\circ} \mathrm{C}$. The reaction mixture was then poured onto crushed ice and acidified to $\mathrm{pH} 3$ with $6.0 \mathrm{~N} \mathrm{HCl}$. The white precipitate that formed was filtered and recrystallized from ethanol to provide 57.43 g of methyl 4-(dimethylcarbamothioyloxy)benzoate (20), 95\% yield.

${ }^{1} \mathrm{H}$ NMR $\left(\mathrm{CDCl}_{3}, 400 \mathrm{MHz}\right) \delta 8.08(\mathrm{~d}, J=8.7 \mathrm{~Hz}, 2 \mathrm{H}), 7.14(\mathrm{~d}, J=8.7 \mathrm{~Hz}, 2 \mathrm{H}), 3.91(\mathrm{~s}$, $3 \mathrm{H}), 3.45$ (s, 3H), $3.35(\mathrm{~s}, 3 \mathrm{H})$.

\subsubsection{Synthesis of methyl 4-(dimethylcarbamoylthio)benzoate (21)}

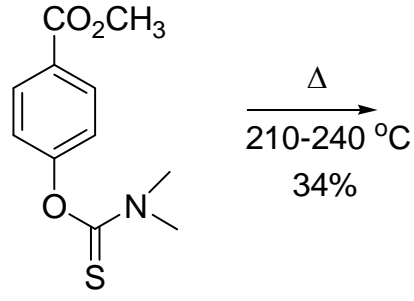

20

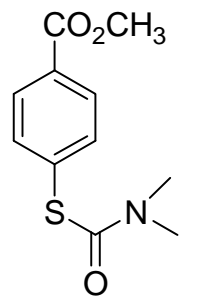

21

Methyl 4-(dimethylcarbamothioyloxy)benzoate (20) (23.80 g 0.099 mol) was added to a $500-\mathrm{mL}$ round bottom flask and then heated to $210-240{ }^{\circ} \mathrm{C}$. After $2.5 \mathrm{~h}$, the flask was cooled to room temperature. The residue was recrystallized from cyclohexane and then twice from ethanol to give $8.0 \mathrm{~g}$ of methyl 4-(dimethylcarbamoylthio)benzoate (21), 34\% yield.

${ }^{1} \mathrm{H}$ NMR $\left(\mathrm{CDCl}_{3}, 400 \mathrm{MHz}\right) \delta 8.03(\mathrm{~d}, J=8.6 \mathrm{~Hz}, 2 \mathrm{H}), 7.57(\mathrm{~d}, J=8.6 \mathrm{~Hz}, 2 \mathrm{H}), 3.92(\mathrm{~s}$, 3H), 3.10 (brs, 3H), 3.04 (brs, 3H). 


\subsubsection{Synthesis of 4-mercaptobenzoic acid (1)}<smiles>CC(=O)c1ccc(SC(=O)N(C)C)cc1</smiles>

21<smiles>COONOC(C)(O)O</smiles>

1

Argon was bubbled through a solution of $\mathrm{NaOH}(3.61 \mathrm{~g}, 0.090 \mathrm{~mol})$ in $40 \mathrm{~mL}$ of $\mathrm{MeOH}$ and $1 \mathrm{~mL}$ of $\mathrm{H}_{2} \mathrm{O}$. After $15 \mathrm{~min}$, methyl 4-(dimethylcarbamoylthio)benzoate (21) (7.75 g, $0.032 \mathrm{~mol}$ ) was added to it, and the mixture was refluxed under Ar for $3 \mathrm{~h}$. The reaction mixture was concentrated in vacuo. The residue was then poured onto crushed ice and acidified to $\mathrm{pH} 2$ with $2.0 \mathrm{~N} \mathrm{HCl}$. The aqueous layer was extracted with ethyl acetate $(3 \times 100 \mathrm{~mL})$, and the combined organic layers were then washed with brine $(2 \times$ $100 \mathrm{~mL})$, dried $\left(\mathrm{MgSO}_{4}\right)$, and concentrated in vacuo. The residue was then recrystallized from benzene to provide $4.0 \mathrm{~g}$ of 4-mercaptobenzoic acid (1) as light yellow crystals, $74 \%$ yield.

${ }^{1} \mathrm{H}$ NMR $\left(\mathrm{CD}_{3} \mathrm{OD}, 400 \mathrm{MHz}\right) \delta 7.87(\mathrm{~d}, J=8.5 \mathrm{~Hz}, 2 \mathrm{H}), 7.36(\mathrm{~d}, J=8.6 \mathrm{~Hz}, 2 \mathrm{H}) .{ }^{13} \mathrm{C}$ NMR (MeOD, $100 \mathrm{MHz}) \delta 169.5,141.0,131.3,128.9,128.4$.

\subsubsection{Synthesis of 4,4'-disulfanediyldibenzoic acid [disulfide of 4-mercaptobenzoic} acid (5)] $]^{118}$<smiles>O=C(O)c1ccc(S)cc1</smiles>

1

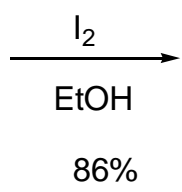

$86 \%$<smiles>[Z]#Sc1ccc(C(=O)O)cc1</smiles>

5 
The 4-mercaptobenzoic acid (1) (1.25 g, $8.11 \mathrm{mmol})$ was dissolved in ethanol, and a saturated solution of $I_{2}$ in $95 \%$ ethanol was slowly added to it. The progress of the reaction was monitored by the disappearance of the brown color of iodine. The saturated solution of iodine was continuously added until a light yellow color persisted. The off white precipitate was filtered and washed with ethanol. The precipitate was dried with benzene under reduced pressure to remove any adsorbed iodine and ethanol to give 1.07 g of product (5), $86 \%$ yield.

${ }^{1} \mathrm{H}$ NMR (DMSO, $\left.400 \mathrm{MHz}\right) \delta 7.93(\mathrm{~d}, J=8.5 \mathrm{~Hz}, 4 \mathrm{H}), \delta 7.63(\mathrm{~d}, J=8.2 \mathrm{~Hz}, 4 \mathrm{H}) ;{ }^{13} \mathrm{C}$ NMR (DMSO, $100 \mathrm{MHz}) \delta 166.6,140.7,130.2,129.7,126.1$.

\subsubsection{Synthesis of 4-mercaptobenzylphosphonic acid (2)}

3.1.2.1 Synthesis of $\boldsymbol{S}$-p-tolyl benzothioate $(\mathbf{2 4})^{120,121}$

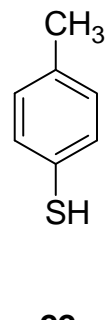

22<smiles>O=C(Cl)c1ccccc1</smiles>

23
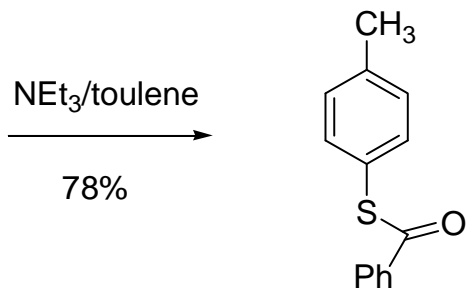

24

To toluene (2 L), p-toluenethiol (22) (51.20 g, $0.412 \mathrm{~mol}$ ) and benzoyl chloride (23) $(58.65 \mathrm{~g}, 0.420 \mathrm{~mol})$ were added. The solution was cooled to $0{ }^{\circ} \mathrm{C}$, and triethylamine (40.77 g, $0.402 \mathrm{~mol}$ ) was added slowly with stirring for $1 \mathrm{~h}$. The reaction mixture was stirred for an additional $1 \mathrm{~h}$, filtered, and the solid washed with toluene. The fitrate was then washed with water, dried $\left(\mathrm{MgSO}_{4}\right)$, filtered, and concentrated in vacuo. The crude was recrystallized from ethanol to provide $73.58 \mathrm{~g}$ of $S$-p-tolyl benzothioate (24), $78 \%$ yield. ${ }^{1} \mathrm{H} \mathrm{NMR}\left(\mathrm{CDCl}_{3}, 400 \mathrm{MHz}\right) \delta 8.01(\mathrm{~d}, J=7.4 \mathrm{~Hz}, 2 \mathrm{H}), 7.60(\mathrm{t}, J=7.4 \mathrm{~Hz}, 1 \mathrm{H})$, $7.48(\mathrm{t}, J=7.9 \mathrm{~Hz}, 2 \mathrm{H}), 7.39(\mathrm{~d}, J=8.1 \mathrm{~Hz}, 2 \mathrm{H}), 7.26(\mathrm{~d}, J=8.3 \mathrm{~Hz}, 2 \mathrm{H}), 2.40(\mathrm{~s}, 3 \mathrm{H})$. 


\subsubsection{Synthesis of $S$-4-(bromomethyl)phenyl benzothioate (25) ${ }^{120}$}

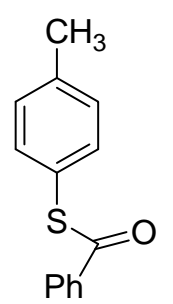

24

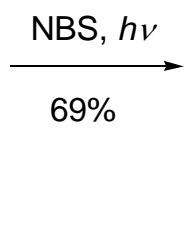

$69 \%$

To deoxygenated benzene (170 mL), S-p-tolyl benzothioate (24) (27.31 g, 0.120 mol) and $N$-bromosuccinimide $(21.39 \mathrm{~g}, 0.120 \mathrm{~mol})$ were added. The reaction mixture was then irradiated with a $250 \mathrm{~W}$ GE heat lamp, providing sufficient energy to initiate reflux. After $30 \mathrm{~min}$ at reflux, the solution was cooled to $0{ }^{\circ} \mathrm{C}$, filtered, and concentrated in vacuo. The residue was then partitioned between $800 \mathrm{~mL}$ of $\mathrm{CH}_{2} \mathrm{Cl}_{2}$ and $400 \mathrm{~mL}$ of water. The aqueous layer was washed with $200 \mathrm{~mL}$ of $\mathrm{CH}_{2} \mathrm{Cl}_{2}$. The organic layers were combined, dried $\left(\mathrm{MgSO}_{4}\right)$, filtered, and concentrated in vacuo. The solid was then recrystallized from hexanes to provide $25.09 \mathrm{~g}$ of product, approximate $69 \%$ yield, as a 24:1 mixture of S-4-(bromomethyl)phenyl benzothioate (25) and S-4(dibromomethyl)phenyl benzothioate.

${ }^{1} \mathrm{H}$ NMR $\left(\mathrm{CDCl}_{3}, 400 \mathrm{MHz}\right) \delta 8.01(\mathrm{~d}, J=8.8 \mathrm{~Hz}, 2 \mathrm{H}), 7.62(\mathrm{t}, J=7.4 \mathrm{~Hz}, 1 \mathrm{H}), 7.52$ $7.47(\mathrm{~m}, 6 \mathrm{H}), 4.52(\mathrm{~s}, 2 \mathrm{H})$.

\subsubsection{Synthesis of $S$-4-((diethoxyphosphoryl)methyl)phenyl benzothioate (26) ${ }^{122}$}

Triethylphosphite $(34.49 \mathrm{~g}, 0.207 \mathrm{~mol})$ was added to the $24: 1$ mixture of S-(4bromomethyl)phenyl benzenecarbothioic acid (25) and S-(4-dibromomethyl)phenyl benzenecarbothioic acid $(24.48 \mathrm{~g}, 0.079 \mathrm{~mol})$. The reaction mixture was then stirred at $105{ }^{\circ} \mathrm{C}$ under a flow of Ar. After 90 min of stirring, the reaction mixture was cooled to -5 
${ }^{\circ} \mathrm{C}$ in the freezer to give crystals. The crystals were washed with hexanes and then recrystallized from hexanes: $\mathrm{CH}_{2} \mathrm{Cl}_{2}$ (95:5) to provide $19.96 \mathrm{~g}$ of $S$-4((diethoxyphosphoryl)methyl)phenyl benzothioate (26), 69\% yield.

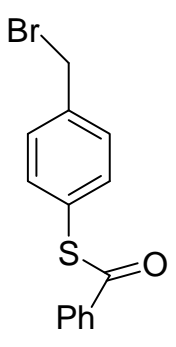

25

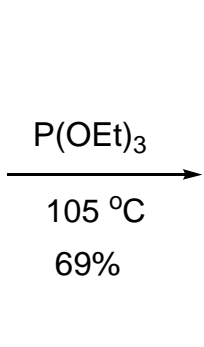

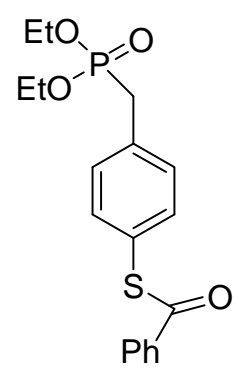

26

${ }^{1} \mathrm{H} \mathrm{NMR}\left(\mathrm{CDCl}_{3}, 400 \mathrm{MHz}\right) \delta 8.01(\mathrm{~d}, J=7.3 \mathrm{~Hz}, 2 \mathrm{H}), 7.60(\mathrm{t}, J=7.4 \mathrm{~Hz}, 1 \mathrm{H}), 7.50-$ $7.45(\mathrm{~m}, 4 \mathrm{H}), 7.39$ (dd, $J=8.3,2.3 \mathrm{~Hz}, 2 \mathrm{H}), 4.04$ (quintet, $J=7.3 \mathrm{~Hz}, 4 \mathrm{H}), 3.20(\mathrm{~d}, J=$ $21.8 \mathrm{~Hz}, 2 \mathrm{H}), 1.26(\mathrm{t}, J=7.1 \mathrm{~Hz}, 6 \mathrm{H})$.

\subsubsection{Synthesis of $S-4-(($ diethoxyphosphoryl)methyl)phenyl ethanethioate (27)}

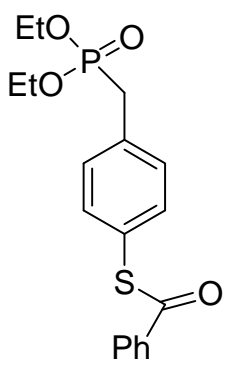

26

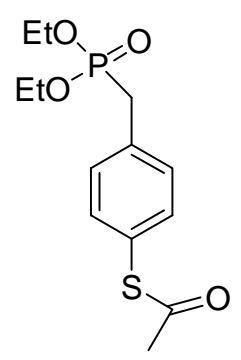

27

Sodium hydride (7.47 $\mathrm{g}$ of $60 \mathrm{wt} \%, 0.186 \mathrm{~mol})$ was added to ethanol $(1150 \mathrm{~mL})$ and the solution was deoxygenated by bubbling Ar through it for 45 min. S-4((diethoxyphosphoryl)methyl)phenyl benzothioate (26) (19.96 g, $0.054 \mathrm{~mol})$ was added to the solution, and after $25 \mathrm{~min}$ the reaction was quenched by adding acetic anhydride $(56.68 \mathrm{~g}, 0.55 \mathrm{~mol})$. Absence of thiol groups were detected by a negative Ellman's test. The solution was reduced under pressure and the slurry was partitioned between $1400 \mathrm{~mL}$ 
of $\mathrm{CH}_{2} \mathrm{Cl}_{2}$ and $700 \mathrm{~mL}$ of sat. aq. sodium bicarbonate. The water layer was washed with an additional $700 \mathrm{~mL}$ of $\mathrm{CH}_{2} \mathrm{Cl}_{2}$. The combined organic layers were dried $\left(\mathrm{MgSO}_{4}\right)$, filtered, and concentrated in vacuo. The crude material was subjected to flash chromatography (1:1 hexanes/ethyl acetate to pure ethyl acetate) to provide $15.29 \mathrm{~g}$ of $\mathrm{S}$ 4-((diethoxyphosphoryl)methyl)phenyl ethanethioate (27) as an oil, 94\% yield. ${ }^{1} \mathrm{H}$ NMR $\left(\mathrm{CDCl}_{3}, 400 \mathrm{MHz}\right) \delta 7.35(\mathrm{~s}, 4 \mathrm{H}), 4.02$ (quintet, $\left.J=7.2 \mathrm{~Hz}, 4 \mathrm{H}\right), 3.16(\mathrm{~d}, J=21.8 \mathrm{~Hz}$, 2H), $2.40(\mathrm{~s}, 3 \mathrm{H}), 1.24$ (t, $J=7.1 \mathrm{~Hz}, 6 \mathrm{H})$.

\subsubsection{Synthesis of 4-mercaptobenzylphosphonic acid (2)}

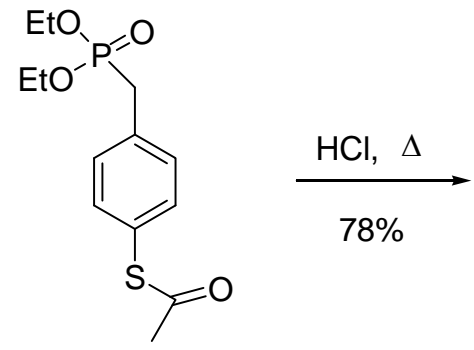

27

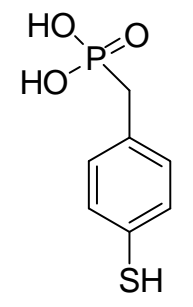

2

The S-4-((diethoxyphosphoryl)methyl)phenyl ethanethioate (27) (3.05 g, 0.0100 mol) was added to conc $\mathrm{HCl}(500 \mathrm{~mL})$ and heated at $130{ }^{\circ} \mathrm{C}$ for $5 \mathrm{~h}$. The reaction mixture was reduced to approximately $100 \mathrm{~mL}$ by concentrating in vacuo, filtered, and cooled to $0{ }^{\circ} \mathrm{C}$. The solution was filtered, and the solid was washed with water. The solid was then lyophilized to provide $1.58 \mathrm{~g}$ of 4-mercaptobenzylphosphonic acid (2), 78\% yield.

${ }^{1} \mathrm{H}$ NMR $\left(\mathrm{CD}_{3} \mathrm{OD}, 400 \mathrm{MHz}\right) \delta 7.22-7.16(\mathrm{~m}, 4 \mathrm{H}), 3.05(\mathrm{~d}, J=21.6 \mathrm{~Hz}, 2 \mathrm{H}) ;{ }^{13} \mathrm{C} \mathrm{NMR}$ $\left(\mathrm{CD}_{3} \mathrm{OD}, 100 \mathrm{MHz}\right) \delta$ 131.6, (d, $\left.J=6 \mathrm{~Hz}\right), 131.5,131.1(\mathrm{~d}, J=4 \mathrm{~Hz}), 130.1(\mathrm{~d}, J=3$ $\mathrm{Hz}), 35.2(\mathrm{~d}, J=135 \mathrm{~Hz})$. 
3.1.2.6 Synthesis of 4,4'-disulfanediylbis(4,1-phenylene)bis(methylene)diphosphonic acid [disulfide of 4-mercaptobenzylphosphonic acid (6)] ${ }^{38}$<smiles>O=P(O)(O)Cc1ccc(S)cc1</smiles>

2

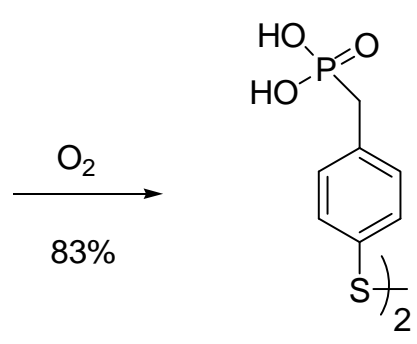

6

The 4-mercaptobenzylphosphonic acid (2) (0.506 g, $2.50 \mathrm{mmol})$ was dissolved in $30 \mathrm{~mL}$ of water, and the resulting mixture was stirred vigorously under air. After 1 week, the mixture was filtered by suction filtration to provide $0.417 \mathrm{~g}$ of 4,4'disulfanediylbis(4,1-phenylene)bis(methylene)diphosphonic acid (6) as a white solid, $83 \%$ yield.

${ }^{1} \mathrm{H}$ NMR (DMSO, $\left.400 \mathrm{MHz}\right) \delta 7.44(\mathrm{~d}, J=7.8 \mathrm{~Hz}, 4 \mathrm{H}), 7.25(\mathrm{~d}, J=6.8 \mathrm{~Hz}, 4 \mathrm{H}), 2.94$ (d, $J=21.5 \mathrm{~Hz}, 4 \mathrm{H}) ;{ }^{13} \mathrm{C}$ NMR (DMSO, $\left.100 \mathrm{MHz}\right) \delta 134.2(\mathrm{~d}, J=9 \mathrm{~Hz}), 133.2(\mathrm{~d}, J=3$ Hz), $130.8(\mathrm{~d}, J=6 \mathrm{~Hz}), 127.5(\mathrm{~d}, J=2 \mathrm{~Hz}), 34.9(\mathrm{~d}, J=131 \mathrm{~Hz})$.

\subsubsection{Synthesis of quaternary ammonium thiol salt (Mono QAS) (3)}

\subsubsection{Synthesis of 1-(4-(benzoylthio)phenyl)- $N, N, N$-trimethylmethanaminium} bromide [quaternary ammonium salt (28)] ${ }^{120}$

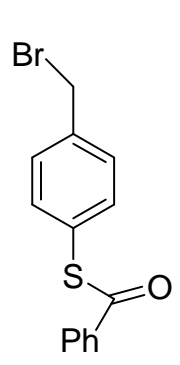

25

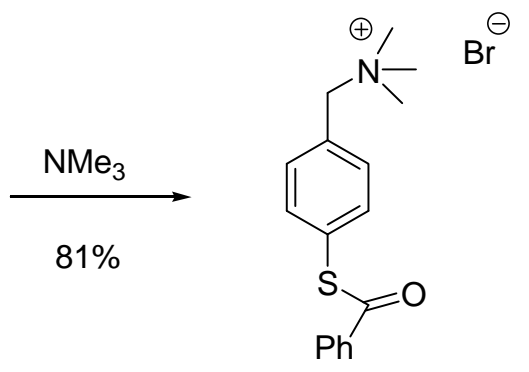

28 
Trimethylamine ( $38.33 \mathrm{~mL}$ of a $33 \%$ solution in ethanol, $0.471 \mathrm{~mol}$ ) was rapidly added to benzyl bromide (25) $(25.0 \mathrm{~g}, 0.081 \mathrm{~mol})$ at $0{ }^{\circ} \mathrm{C}$ and stirred. After $10 \mathrm{~min}$, the mixture was concentrated in vacuo, and then the residue was recrystallized from EtOAc/EtOH (95:5) to give $18.85 \mathrm{~g}$ of the quaternary ammonium salt (28), $81 \%$ yield. ${ }^{1} \mathrm{H} \mathrm{NMR}\left(\mathrm{CDCl}_{3}, 400 \mathrm{MHz}\right) \delta 7.98(\mathrm{~d}, J=7.2 \mathrm{~Hz}, 2 \mathrm{H}), 7.81(\mathrm{~d}, J=8.2 \mathrm{~Hz}, 2 \mathrm{H}), 7.63-$ $7.59(\mathrm{~m}, 3 \mathrm{H}), 7.49(\mathrm{t}, J=8.0 \mathrm{~Hz}, 2 \mathrm{H}), 5.21(\mathrm{~s}, 2 \mathrm{H}), 3.42(\mathrm{~s}, 9 \mathrm{H})$.

\subsubsection{Synthesis of 1-(4-(mercaptophenyl)- $N, N, N$-trimethylmethanaminium bromide [Mono QAS (3)] ${ }^{120}$}

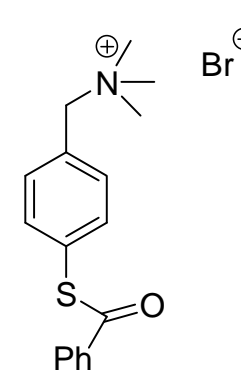

28

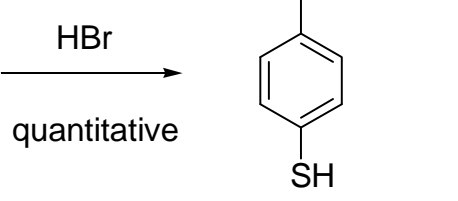

3

The quaternary ammonium salt (28) $(0.93 \mathrm{~g}, 2.54 \mathrm{mmol})$ was lyophilized from water and then dissolved in $3 \mathrm{~mL}$ of $\mathrm{HBr}$ (48 wt.\% in water) and $15 \mathrm{~mL}$ of water. The solution was refluxed for $5 \mathrm{~h}$, cooled to $0{ }^{\circ} \mathrm{C}$, filtered, extracted with $2 \times 30 \mathrm{~mL}$ EtOAc, and partially concentrated. The solution was then lyophilized several times by dissolving the residue in water to give Mono QAS (3) in quantitative yield.

${ }^{1} \mathrm{H}$ NMR $\left(\mathrm{CD}_{3} \mathrm{OD}, 400 \mathrm{MHz}\right) \delta 7.44$ (s, 4H), 4.50 (s, 2H), 3.10 (s, 9H).

\subsubsection{Synthesis of $1,1^{\prime}$-(4,4'-disulfanediylbis(4,1-phenylene)bis( $N, N, N$ -} trimethylmethanaminium) bromide [disulfide of Mono QAS (7)] ${ }^{38}$ 


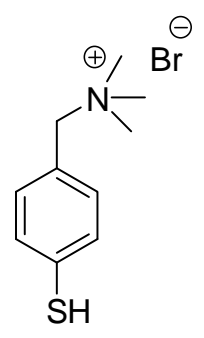

3

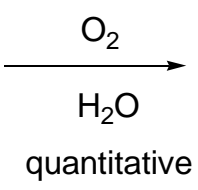

Disulfide of Mono QAS (7) was prepared from Mono QAS (3). Mono QAS (3) was dissolved in $50 \mathrm{~mL}$ of water and the resulting mixture was stirred vigorously under air. After 6 months, the solution was lyophilized to provide disulfide of Mono QAS (7). ${ }^{1} \mathrm{H}$ NMR $\left(\mathrm{CD}_{3} \mathrm{OD}, 400 \mathrm{MHz}\right) \delta 7.68(\mathrm{~d}, J=8.5 \mathrm{~Hz}, 4 \mathrm{H}), 7.61(\mathrm{~d}, J=8.5 \mathrm{~Hz}, 4 \mathrm{H}), 4.60$ $(\mathrm{s}, 4 \mathrm{H}), 3.13(\mathrm{~s}, 18 \mathrm{H})$.

\subsubsection{Synthesis of 4-mercaptobenzene sulfonic acid (4)}

\subsubsection{Synthesis of 4-mercaptobenzene sulfonic acid (4) ${ }^{123}$}<smiles>Nc1ccc(S(=O)(=O)O)cc1</smiles>
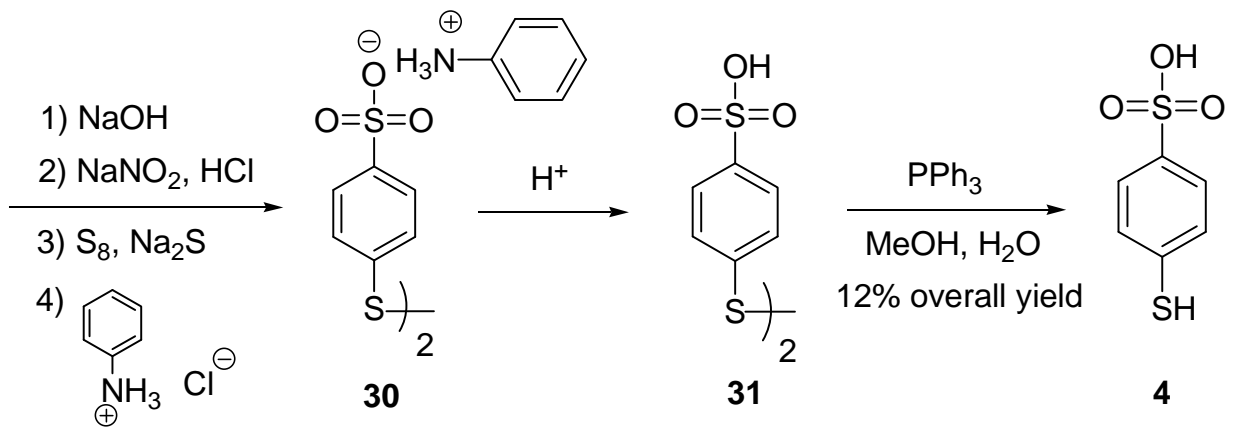

A solution of sodium hydroxide $(20.05 \mathrm{~g}, 0.50 \mathrm{~mol})$ in $500 \mathrm{~mL}$ of water was prepared, and then 4-aminobenzenesulfonic acid (29) (86.48 g, $0.50 \mathrm{~mol}$ ) was dissolved in it. To the reaction mixture, $100 \mathrm{~mL}$ of conc $\mathrm{HCl}$ was added followed by gradual addition of a solution of sodium nitrite $(34.54 \mathrm{~g}, 0.50 \mathrm{~mol})$ in $100 \mathrm{~mL}$ of water at $1-3{ }^{\circ} \mathrm{C}$. The resulting suspension was then slowly added into a solution of sodium disulfide at 1-3 ${ }^{\circ} \mathrm{C}$. The solution of sodium disulfide was prepared by co-melting sulfur $(16.01 \mathrm{~g}, 0.50$ 
mol) and sodium sulfide nonahydrate $(120.1 \mathrm{~g}, 0.50 \mathrm{~mol})$ at $65{ }^{\circ} \mathrm{C}$, in $500 \mathrm{~mL}$ of water. The reaction mixture was warmed until the evolution of gas ceased and then returned to room temperature. The insoluble material was filtered off. To the filtrate, a freshly prepared solution of aniline $(93.4 \mathrm{~g}, 1.00 \mathrm{~mol})$ and conc $\mathrm{HCl}(84 \mathrm{~mL})$ in $200 \mathrm{~mL}$ of water were added. The mixture was then cooled overnight. The precipitate was filtered, recrystallized from water, and then washed with ethanol and n-hexane to give $23.87 \mathrm{~g}$ mixture (30:70) of a mono- and dianilinium 4,4'-dithiobis(benzenesulfonate) (30) as colorless crystals.

${ }^{1} \mathrm{H}$ NMR (DMSO, $\left.400 \mathrm{MHz}\right) \delta 7.59$ (d, $\left.J=8.4 \mathrm{~Hz}, 4 \mathrm{H}\right), 7.48-7.42(\mathrm{~m}, 6.8 \mathrm{H}), 7.31$ (t, $J$ $=7.4 \mathrm{~Hz}, 1.4 \mathrm{H}), 7.25(\mathrm{~d}, J=8.6 \mathrm{~Hz}, 2.8 \mathrm{H})$.

The mixture of a mono- and dianilinium 4,4'-dithiobis(benzenesulfonate) (30) $(8.70 \mathrm{~g})$ was then subjected to ion-exchange column chromatography $(63 \mathrm{~mL}$ of Dowex 50X2-200, H-form) using methanol: water $(2: 1)$ as the eluent. The acidic fractions were collected and reduced under pressure to give the residue (31).

${ }^{1} \mathrm{H}$ NMR $\left(\mathrm{CD}_{3} \mathrm{OD}, 400 \mathrm{MHz}\right) \delta 7.77(\mathrm{~d}, J=8.5 \mathrm{~Hz}, 4 \mathrm{H}), 7.58(\mathrm{~d}, J=8.5 \mathrm{~Hz}, 4 \mathrm{H})$.

The residue (31) was dissolved in $145 \mathrm{~mL}$ of methanol, and then triphenylphosphine $(8.84 \mathrm{~g}, 0.033 \mathrm{~mol})$ and about $1 \mathrm{~mL}$ of water were added. The reaction mixture was stirred overnight at room temperature and then evaporated in vacuo. The residue was dissolved in $90 \mathrm{~mL}$ of $\mathrm{CH}_{2} \mathrm{Cl}_{2}$, and the organic layer was washed with water. The organic layer was dried $\left(\mathrm{MgSO}_{4}\right)$, filtered, reduced under pressure, and then the residue was dissolved in dioxane followed by filtration of insoluble materials. The filtrate was reduced under pressure, and the resulting oil was recrystallized from benzene to give 4-mercaptobenzensulfonic acid (4) (4.28 g, 12\% overall yield) as yellow crystals. 
${ }^{1} \mathrm{H}$ NMR $\left(\mathrm{CD}_{3} \mathrm{OD}, 400 \mathrm{MHz}\right) \delta 7.66(\mathrm{~d}, J=8.5 \mathrm{~Hz}, 2 \mathrm{H}), 7.31(\mathrm{~d}, J=8.5 \mathrm{~Hz}, 2 \mathrm{H})$.

\subsubsection{Sodium salt of sulfonic acid disulfide (8)}<smiles>Nc1ccc(S(=O)(=O)O)cc1</smiles>

29
1) $\mathrm{NaOH}$

2) $\mathrm{NaNO}_{2}, \mathrm{HCl}$

3) $\mathrm{S}_{8}, \mathrm{Na}_{2} \mathrm{~S}$

4)

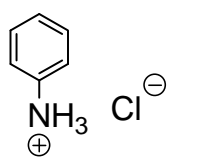

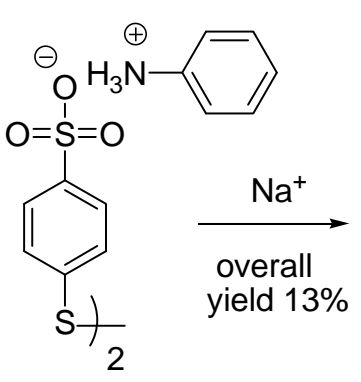

30<smiles>O=S(=O)([O-])c1ccc(S(=O)(=O)[O-])cc1</smiles>

8

Sodium ions were exchanged with $\mathrm{H}^{+}$ions by treating the Dowex $50 \mathrm{wx} 2 \mathrm{H}^{+}$form with $0.1 \mathrm{M} \mathrm{NaOH}$ and $0.5 \mathrm{M} \mathrm{NaCl}$ in $500 \mathrm{~mL}$ of water. Water was run through the resin to make it neutral followed by methanol:water $(2: 1)$ to equilibrate the resin with methanol:water. The dianilinium salt (30) $(5.16 \mathrm{~g}, 9.15 \mathrm{mmol})$ was then subjected to ion exchange resin $\left(\mathrm{Na}^{+}\right.$form) with methanol:water $(2: 1)$ as the eluent. The fractions those were UV active were collected and evaporated in vacuo to give the sodium salt of sulfonic acid disulfide (8) (3.02 g, 13\% yield).

${ }^{1} \mathrm{H}$ NMR (DMSO, $\left.400 \mathrm{MHz}\right) \delta 7.59$ (d, $\left.J=8.4 \mathrm{~Hz}, 4 \mathrm{H}\right), 7.46(\mathrm{~d}, J=8.4 \mathrm{~Hz}, 4 \mathrm{H})$.

3.2 Synthesis of ortho-and para-substituted aromatic ethylene glycol dithiols (9-15)

3.2.1 Synthesis of di-, tri-, tetra-, and hexaethylene glycol thiols (35, 36, 43, and 44)

3.2.1.1 Synthesis of 2-(2-mercaptoethoxy)ethanol and 2-[2-(2mercaptoethoxy)ethoxy]ethanol [di- and triethylene glycol thiols (35 and 36)] ${ }^{124}$

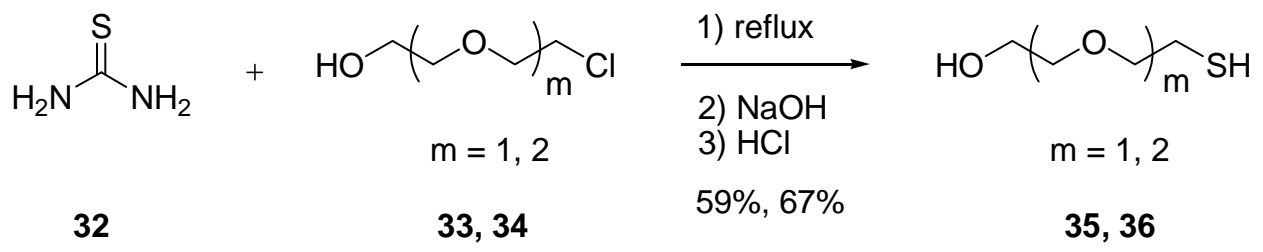




\section{General procedure}

Thiourea (32) (3.67 g, $0.048 \mathrm{~mol})$ and 2-[2-(2-chloroethoxy)ethoxy]ethanol (34)

(5.27 $\mathrm{g}, 0.031 \mathrm{~mol})$ were dissolved in $100 \mathrm{~mL}$ of water, and the solution was bubbled with argon for $30 \mathrm{~min}$ and then heated to reflux under argon. After $18 \mathrm{~h}$, the reaction mixture was cooled to room temperature, and then a solution of $\mathrm{NaOH}(10.53 \mathrm{~g}, 0.263$ mol) in $50 \mathrm{~mL}$ of deoxygenated $\mathrm{H}_{2} \mathrm{O}$ was added to it. The reaction mixture was refluxed for another $3 \mathrm{~h}$ and then poured onto ice and adjusted to $\mathrm{pH} 4$ with conc $\mathrm{HCl}$ under argon. The reaction mixture was washed with $\mathrm{CHCl}_{3}(3 \times 100 \mathrm{~mL})$. The organic layers were combined and then extracted with brine $(2 \times 100 \mathrm{~mL})$, dried over $\mathrm{MgSO}_{4}$, filtered, and concentrated under reduced pressure to leave $3.50 \mathrm{~g}$ of the triethylene glycol thiol (36) as a colorless oil, $67 \%$ yield.

2-(2-Mercaptoethoxy)ethanol [diethylene glycol thiol (35)]: 59\% yield, ${ }^{1} \mathrm{H}$ NMR $\left(\mathrm{CDCl}_{3}, 400 \mathrm{MHz}\right) \delta 3.73(\mathrm{q}, J=4.8 \mathrm{~Hz}, 2 \mathrm{H}), 3.61(\mathrm{t}, J=6.3 \mathrm{~Hz}, 2 \mathrm{H}), 3.57(\mathrm{t}, J=4.7$ $\mathrm{Hz}, 2 \mathrm{H}), 2.70(\mathrm{dt}, J=8.2,6.3 \mathrm{~Hz}, 2 \mathrm{H}), 2.29(\mathrm{t}, J=5.8 \mathrm{~Hz}, 1 \mathrm{H}), 1.56(\mathrm{t}, J=8.2 \mathrm{~Hz}, 1 \mathrm{H})$. 2-[2-(2-Mercaptoethoxy)ethoxy]ethanol [triethylene glycol thiol (36)]: 67\% yield, ${ }^{1} \mathrm{H}$ $\operatorname{NMR}\left(\mathrm{CDCl}_{3}, 400 \mathrm{MHz}\right) \delta 3.73(\mathrm{t}, J=4.5 \mathrm{~Hz}, 2 \mathrm{H}), 3.69-3.60(\mathrm{~m}, 8 \mathrm{H}), 2.70(\mathrm{dt}, J=8.2$, $6.4 \mathrm{~Hz}, 2 \mathrm{H}), 2.42$ (brs, 1H), $1.58(\mathrm{t}, J=8.2 \mathrm{~Hz}, 1 \mathrm{H})$.

\subsubsection{Synthesis of 2-[2-(2-(2-hydroxyethoxy)ethoxy)ethoxy]ethyl-4-} methylbenzenesulfonate and 17-hydroxy-3,6,9,12,15-pentaoxaheptadecyl-4methylbenzenesulfonate [tetra- and hexaethylene glycol monotosylate (41 and 42)] ${ }^{125}$

\section{General procedure}

para-Toluenesulfonyl chloride (14.25 g, $0.075 \mathrm{~mol})$ was suspended in tetraethylene glycol (39) $(29.1 \mathrm{~g}, 0.15 \mathrm{~mol})$ at $0{ }^{\circ} \mathrm{C}$, and triethylamine $(18.75 \mathrm{~mL}, 0.133$ 
mol) was then added drop wise to the suspension while maintaining the reaction mixture at $0{ }^{\circ} \mathrm{C}$. The suspension was stirred at $0{ }^{\circ} \mathrm{C}$ for $1 \mathrm{~h}$ and then for $16 \mathrm{~h}$ at room temperature.

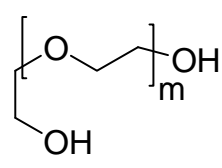

$m=3,5$

39,40

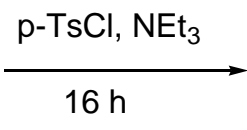

$45 \%, 50 \%$

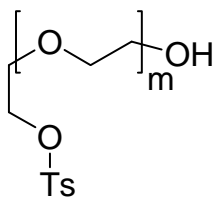

$m=3,5$

41, 42

The resulting suspension was dissolved in $500 \mathrm{~mL}$ of $\mathrm{CH}_{2} \mathrm{Cl}_{2}$ and washed with $1 \mathrm{M} \mathrm{HCl}$ ( $2 \times 125 \mathrm{~mL})$ followed by $250 \mathrm{~mL}$ of distilled water. The organic layer was dried with $\mathrm{MgSO}_{4}$, filtered, and reduced under pressure to give $17.82 \mathrm{~g}$ of the mono- and ditosylate

of tetraethylene glycol. The residue was then purified by flash chromatography using hexane/ethyl acetate $(3: 1, \mathrm{v} / \mathrm{v}) \rightarrow(0: 1, \mathrm{v} / \mathrm{v})$ to give $11.23 \mathrm{~g}$ of tetraethylene glycol monotosylate (41), $45 \%$ yield .

\section{2-[2-(2-(2-Hydroxyethoxy)ethoxy)ethoxy]ethyl-4-methylbenzenesulfonate} [tetraethylene glycol monotosylate (41)]: 45\% yield, ${ }^{1} \mathrm{H}$ NMR $\left(\mathrm{CDCl}_{3}, 400 \mathrm{MHz}\right) \delta$ $7.80(\mathrm{~d}, J=8.3 \mathrm{~Hz}, 2 \mathrm{H}), 7.34(\mathrm{~d}, J=8.0 \mathrm{~Hz}, 2 \mathrm{H}), 4.16(\mathrm{t}, J=4.8 \mathrm{~Hz}, 2 \mathrm{H}), 3.70-3.59$ (m, 14H) 2.54 (brs, 1H), 2.45 (s, 3H).

2,2'-(2,2'-Oxybis(ethane-2,1-diyl)bis(oxy))bis(ethane-2,1-diyl)bis(4-

methylbenzenesulfonate [tetraethylene glycol ditosylate]: ${ }^{1} \mathrm{H} \mathrm{NMR}\left(\mathrm{CDCl}_{3}, 400 \mathrm{MHz}\right)$ $\delta 7.77(\mathrm{~d}, J=8.3 \mathrm{~Hz}, 4 \mathrm{H}), 7.32(\mathrm{~d}, J=8.3 \mathrm{~Hz}, 4 \mathrm{H}), 4.13(\mathrm{t}, J=4.8 \mathrm{~Hz}, 4 \mathrm{H}), 3.66$ (t, $J=$ $4.8 \mathrm{~Hz}, 4 \mathrm{H}), 3.54(\mathrm{~m}, 8 \mathrm{H}) 2.43(\mathrm{~s}, 6 \mathrm{H})$.

17-Hydroxy-3,6,9,12,15-pentaoxaheptadecyl-4-methylbenzenesulfonate 
[hexaethylene glycol monotosylate (42)]: $50 \%$ yield, ${ }^{1} \mathrm{H} \mathrm{NMR}\left(\mathrm{CDCl}_{3}, 400 \mathrm{MHz}\right) \delta$ $7.79(\mathrm{~d}, J=8.3 \mathrm{~Hz}, 2 \mathrm{H}), 7.35(\mathrm{~d}, J=8.2 \mathrm{~Hz}, 2 \mathrm{H}), 4.15(\mathrm{t}, J=4.8 \mathrm{~Hz}, 2 \mathrm{H}), 3.71-3.58(\mathrm{~m}$, 22H), 2.90 (brs, 1H), 2.45 (s, 3H); ${ }^{13} \mathrm{C}$ NMR $\left(\mathrm{CDCl}_{3}, 100 \mathrm{MHz}\right) \delta$ 144.78, 133.00, $129.81,127.93,72.49,70.67,70.55,70.52,70.50,70.49,70.46,70.28,69.27,68.62$, $61.64,21.60$.

3.2.1.3 Synthesis of 2-[2-(2-(2-mercaptoethoxy)ethoxy)ethoxy]ethanol and 17mercapto-3,6,9,12,15-pentaoxaheptadecan-1-ol [tetra- and hexaethylene glycol thiol (43 and 44)] $]^{125}$

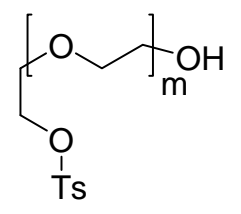

$m=3,5$

41,42

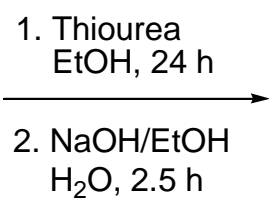

$89 \%, 58 \%$

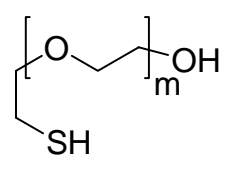

$m=3,5$

43,44

\section{General procedure}

Tetraethylene glycol monotosylate (41) (5.32 g, 0.015 mole) and thiourea (1.16 g, 0.015 mole) were dissolved in $36 \mathrm{~mL}$ of absolute ethanol and heated to reflux under an argon atmosphere. After $24 \mathrm{~h}$, a solution of $\mathrm{NaOH}(1.56 \mathrm{~g}, 0.039 \mathrm{~mole})$ in $22 \mathrm{~mL}$ of ethanol/water $(9: 1 \mathrm{v} / \mathrm{v})$ was added and then the solution was reflux under an argon atmosphere for another $2.5 \mathrm{~h}$. Subsequently, the reaction mixture was cooled down to room temperature and then acidified to $\mathrm{pH} 2$ with conc $\mathrm{HCl}$. The acidic solution was reduced under pressure, and then the residue was dissolved in $64 \mathrm{~mL}$ of ethyl acetate/ethanol mixture $(5: 1, \mathrm{v} / \mathrm{v})$ and heated for $5 \mathrm{~min}$ at $50{ }^{\circ} \mathrm{C}$ before filtering. The 
crude product was purified by flash chromatography using ethyl acetate/ethanol (10:1, $\mathrm{v} / \mathrm{v}$ ) giving $2.84 \mathrm{~g}$ of a tetraethylene glycol thiol (43) as yellow oil, $89 \%$ yield.

2-[2-(2-(2-Mercaptoethoxy)ethoxy)ethoxy]ethanol [tetraethylene glycol thiol (43)]: $89 \%$ yield, ${ }^{1} \mathrm{H}$ NMR $\left(\mathrm{CDCl}_{3}, 400 \mathrm{MHz}\right) \delta 3.70-3.58(\mathrm{~m}, 14 \mathrm{H}), 2.68(\mathrm{dt}, J=8.1,6.4 \mathrm{~Hz}$, 2H), $1.61(\mathrm{t}, J=8.2 \mathrm{~Hz}, 1 \mathrm{H})$.

17-Mercapto-3,6,9,12,15-pentaoxaheptadecan-1-ol [hexaethylene glycol thiol (44)]: $58 \%$ yield, ${ }^{1} \mathrm{H} \mathrm{NMR}\left(\mathrm{CDCl}_{3}, 400 \mathrm{MHz}\right) \delta 3.67-3.54(\mathrm{~m}, 22 \mathrm{H}), 2.65(\mathrm{t}, J=4.8 \mathrm{~Hz}, 2 \mathrm{H})$; ${ }^{13} \mathrm{C}$ NMR $\left(\mathrm{CDCl}_{3}, 100 \mathrm{MHz}\right) \delta 74.13,73.72,71.63,71.62,71.60,71.58,71.57,71.45$, $71.21,62.28,24.76$.

3.2.2 Synthesis of di-, tri-, tetra-, and hexaethylene glycol disulfides $(37,38,45$, and 46)

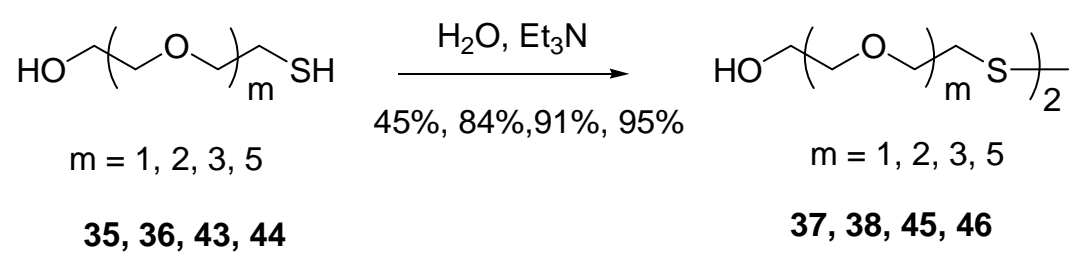

\section{General procedure}

Triethylamine $(0.5 \mathrm{~mL}, 3.58 \mathrm{mmol})$ was added to a solution of 2-[2-(2mercaptoethoxy) ethoxy]ethanol (triethylene glycol thiol) (36) (3.5 g, $21.08 \mathrm{mmol})$ in 25 $\mathrm{mL}$ of distilled water. The solution was stirred vigorously for 1 week under air. The reaction mixture was brought to $\mathrm{pH} 4$ with conc $\mathrm{HCl}$, and the aqueous layer was then extracted with $\mathrm{CHCl}_{3}(3 \times 25 \mathrm{~mL})$. The organic layers were combined and washed with brine $(2 \times 25 \mathrm{~mL})$, dried over $\mathrm{MgSO}_{4}$, filtered, and reduced under pressure to give $2.93 \mathrm{~g}$ of triethylene glycol disulfide (38) as a yellow oil, $84 \%$ yield. 
2,2'-(2,2'-Disulfanediylbis(ethane-2,1-diyl)bis)oxy))diethanol [diethylene glycol disulfide (37)]: 45\% yield, ${ }^{1} \mathrm{H} \mathrm{NMR}\left(\mathrm{CDCl}_{3}, 400 \mathrm{MHz}\right) \delta 3.78-3.73(\mathrm{~m}, 8 \mathrm{H}), 3.60(\mathrm{t}, J$ $=4.4 \mathrm{~Hz}, 4 \mathrm{H}), 2.94(\mathrm{t}, J=6.3 \mathrm{~Hz}, 4 \mathrm{H}), 2.61(\mathrm{t}, J=6.2 \mathrm{~Hz}, 2 \mathrm{H})$.

3,6,13,16-Tetraoxa-9,10-dithiaoctadecane-1,18-diol [triethylene glycol disulfide (38)]: 84\% yield, ${ }^{1} \mathrm{H}$ NMR ( $\left.\mathrm{CDCl}_{3}, 400 \mathrm{MHz}\right) \delta 3.75$ - 3.70 (m, 8H), 3.66 - 3.63 (m, 8H), $3.59(\mathrm{t}, J=4.5 \mathrm{~Hz}, 4 \mathrm{H}), 3.04(\mathrm{t}, J=5.5 \mathrm{~Hz}, 2 \mathrm{H}) 2.90(\mathrm{t}, J=6.6 \mathrm{~Hz}, 4 \mathrm{H}) ;{ }^{13} \mathrm{C} \mathrm{NMR}$ $\left(\mathrm{CDCl}_{3}, 100 \mathrm{MHz}\right) \delta 72.6,70.4,70.3,69.6,61.7,38.4$.

3,6,9,16,19,22-Hexaoxa-12,13-dithiatetracosane-1,24-diol [tetraethylene glycol disulfide (45)]: 91\% yield, ${ }^{1} \mathrm{H} \mathrm{NMR}\left(\mathrm{CDCl}_{3}, 400 \mathrm{MHz}\right) \delta 3.72(\mathrm{t}, J=6.7 \mathrm{~Hz}, 4 \mathrm{H}), 3.68$ $3.63(\mathrm{~m}, 20 \mathrm{H}), 3.60$ (t, $J=4.5 \mathrm{~Hz}, 4 \mathrm{H}), 2.89$ (t, $J=6.7 \mathrm{~Hz}, 4 \mathrm{H}), 2.74$ (t, $J=5.7 \mathrm{~Hz}, 2 \mathrm{H})$;

${ }^{13} \mathrm{C} \mathrm{NMR}\left(\mathrm{CDCl}_{3}, 100 \mathrm{MHz}\right) \delta 72.4,70.4,70.3,70.1,69.4,61.4,38.2$.

3,6,9,12,15,22,25,28,31,34-Decaoxa-18,19-dithiahexatriacontane-1,36-diol

[hexaethylene glycol disulfide (46)]: 95\% yield, ${ }^{1} \mathrm{H} \mathrm{NMR}\left(\mathrm{CDCl}_{3}, 400 \mathrm{MHz}\right) \delta 3.68$ $3.51(\mathrm{~m}, 44 \mathrm{H}), 2.90(\mathrm{brs}, 2 \mathrm{H}), 2.82(\mathrm{t}, J=6.7 \mathrm{~Hz}, 4 \mathrm{H}) ;{ }^{13} \mathrm{C} \mathrm{NMR}\left(\mathrm{CDCl}_{3}, 100 \mathrm{MHz}\right) \delta$ $72.7,70.53,70.52,70.45,70.44,70.42,70.3,70.2,69.5,61.5,38.4$.

3.2.3 Synthesis of ortho- and para-substituted aromatic ethylene glycol dithiols polymer $^{126}$

\section{General procedure}

In $4 \mathrm{~mL}$ of THF was dissolved 4,4'-dithiobenzoic acid (5) (0.213 g, $0.696 \mathrm{mmol})$, and $10 \mu \mathrm{L}$ of DMF was added to it. The solution was cooled to $0{ }^{\circ} \mathrm{C}$, and slowly oxalyl chloride (48) (0.883 g, $6.96 \mathrm{mmol}$ ) was added into the solution via syringe. The solution was stirred for $3 \mathrm{~h}$ and then reduced under pressure to give a yellow oil. Yellow oil was dissolved in $6 \mathrm{~mL}$ of $\mathrm{CH}_{2} \mathrm{Cl}_{2}$ and then transferred to a flask containing triethylene glycol 


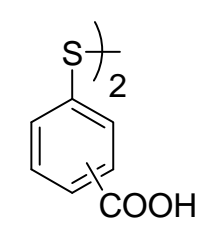

$$
\text { ortho }=\mathbf{4 7}
$$$$
\text { para }=\mathbf{5}
$$

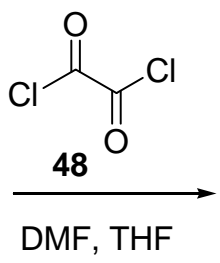<smiles>CSc1ccc(C(=O)Cl)cc1</smiles>

ortho $=49$ para $=55$

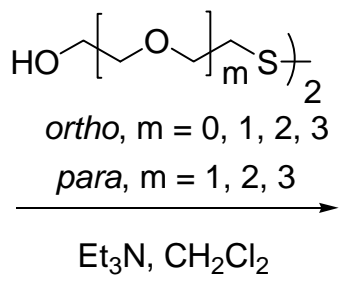

ortho $=50,37,38,45$

para $=37,38,45$

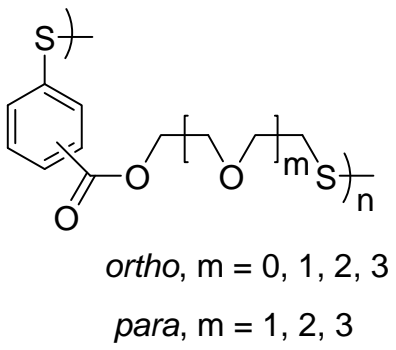

ortho $=51,52,53,54$

para $=56,57,58$

disulfide (38) $(0.981 \mathrm{~g}, 2.98 \mathrm{mmol}), \mathrm{Et}_{3} \mathrm{~N}(0.77 \mathrm{~mL}, 5.57 \mathrm{mmol})$, and $46 \mathrm{~mL}$ of $\mathrm{CH}_{2} \mathrm{Cl}_{2}$ at $0{ }^{\circ} \mathrm{C}$. The reaction mixture was stirred at $0{ }^{\circ} \mathrm{C}$ for $30 \mathrm{~min}$ and gradually warmed to room temperature, and then stirring continued overnight. The reaction mixture was dissolved in $50 \mathrm{~mL}$ of $\mathrm{CH}_{2} \mathrm{Cl}_{2}$ and then washed with $50 \mathrm{~mL}$ of $0.1 \mathrm{~N} \mathrm{HCl}$. The organic layer was then washed with water $(2 \times 50 \mathrm{~mL})$, dried $\left(\mathrm{MgSO}_{4}\right)$, filtered, and reduced under pressure to give $0.81 \mathrm{~g}$ of a polymer (57).

3.2.4 Reduction of ortho- and para-substituted aromatic ethylene glycol dithiol polymer with dithiothreitol (DTT)
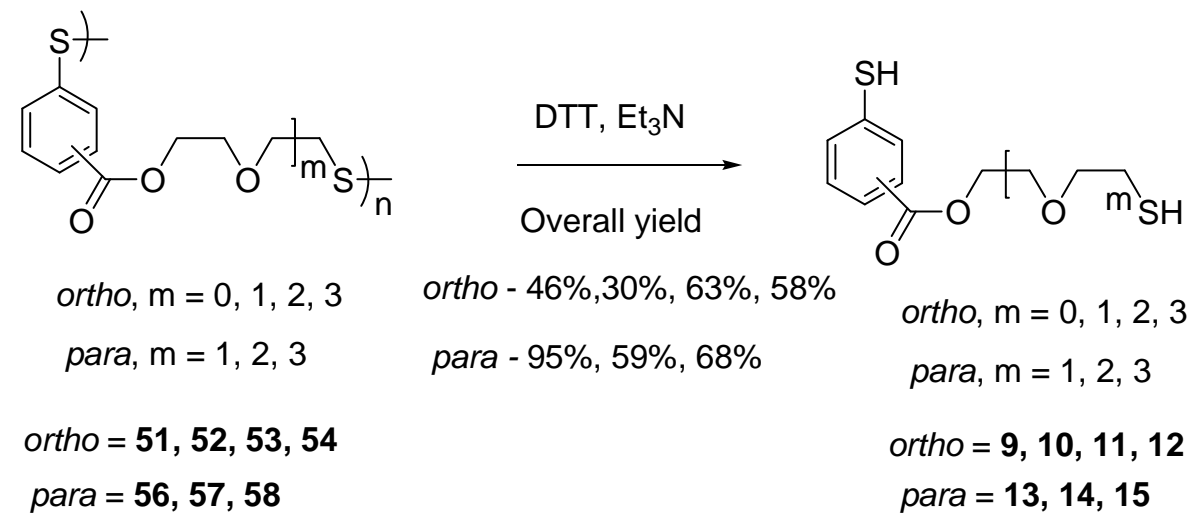


\section{General procedure}

Triethylamine $(0.5 \mathrm{~mL}, 3.59 \mathrm{mmol})$ and DTT (1.032 $\mathrm{g}, 6.70 \mathrm{mmol})$ were added to a concentrated solution of a polymer (57) $(0.81 \mathrm{~g})$ in $15 \mathrm{~mL}$ of $\mathrm{CH}_{2} \mathrm{Cl}_{2}$. The reaction mixture was stirred for $2 \mathrm{~h}$ and $3 \mathrm{~h}$ for triethylene glycol polymer and tetraethylene glycol polymer, respectively, under argon and then the mixture was extracted with $50 \mathrm{~mL}$ of ethyl acetate. The organic layer was washed with water $(2 \times 50 \mathrm{~mL})$, dried over $\mathrm{MgSO}_{4}$, filtered, and concentrated under reduced pressure to give the crude product. The crude product was then purified by silica gel chromatography using $\mathrm{CH}_{2} \mathrm{Cl}_{2}$ : hexane $(2: 1$ for monoethylene glycol dithiol and diethylene glycol dithiol, 4:1 for triethylene glycol dithiol, and 6:1 for tetraethylene glycol dithiol) to give $0.124 \mathrm{~g}$ of a para-substituted aromatic triethylene glycol dithiol (14) as yellow oil , 59\% overall yield.

\section{2-mercaptoethyl-2-mercaptobenzoate [ortho-substituted aromatic monoethylene} glycol dithiol (9)]: $46 \%$ overall yield, ${ }^{1} \mathrm{H} \mathrm{NMR}\left(\mathrm{CDCl}_{3}, 400 \mathrm{MHz}\right) \delta 8.04(\mathrm{~d}, J=7.4 \mathrm{~Hz}$, 1H), $7.33-7.30(\mathrm{~m}, 2 \mathrm{H}), 7.17(\mathrm{ddd}, J=8.0,6.0,2.5 \mathrm{~Hz}, 1 \mathrm{H}), 4.61(\mathrm{~s}, 1 \mathrm{H}), 4.45$ (t, $J=$ $6.6 \mathrm{~Hz}, 2 \mathrm{H}), 2.90(\mathrm{dt}, J=8.5,6.6 \mathrm{~Hz}, 2 \mathrm{H}), 1.59(\mathrm{t}, J=8.6 \mathrm{~Hz}, 1 \mathrm{H}) ;{ }^{13} \mathrm{C} \mathrm{NMR}\left(\mathrm{CDCl}_{3}\right.$, $100 \mathrm{MHz}) \delta 166.4,138.5,132.8,131.9,131.1,125.8,124.9,66.6,23.5$.

2-(2-mercaptoethoxy)ethyl-2-mercaptobenzoate [ortho-substituted aromatic diethylene glycol dithiol (10)]: $30 \%$ overall yield, ${ }^{1} \mathrm{H} \mathrm{NMR}\left(\mathrm{CDCl}_{3}, 400 \mathrm{MHz}\right) \delta 8.05$ $(\mathrm{d}, J=8.5 \mathrm{~Hz}, 1 \mathrm{H}), 7.32-7.30(\mathrm{~m}, 2 \mathrm{H}), 7.16(\mathrm{ddd}, J=8.1,5.8,2.8 \mathrm{~Hz}, 1 \mathrm{H}), 4.66(\mathrm{~s}$, 1H), $4.48(\mathrm{t}, J=4.7 \mathrm{~Hz}, 2 \mathrm{H}), 3.81(\mathrm{t}, J=4.8 \mathrm{~Hz}, 2 \mathrm{H}), 3.66(\mathrm{t}, J=6.3 \mathrm{~Hz}, 2 \mathrm{H}), 2.71(\mathrm{dt}, J$ $=8.1,6.3 \mathrm{~Hz}, 2 \mathrm{H}), 1.60(\mathrm{t}, J=8.2 \mathrm{~Hz}, 1 \mathrm{H}) ;{ }^{13} \mathrm{C} \mathrm{NMR}\left(\mathrm{CDCl}_{3}, 100 \mathrm{MHz}\right) \delta 166.7,134.4$, $132.7,132.0,131.0,129.6,124.8,72.9,68.9,64.3,24.5$. 
aromatic triethylene glycol dithiol (11)]: $63 \%$ overall yield, ${ }^{1} \mathrm{H} \mathrm{NMR}\left(\mathrm{CDCl}_{3}, 400\right.$ MHz) $\delta 8.03(\mathrm{~d}, J=7.6 \mathrm{~Hz}, 1 \mathrm{H}), 7.30-7.28(\mathrm{~m}, 2 \mathrm{H}), 7.13(\mathrm{ddd}, J=8.1,5.6,2.9 \mathrm{~Hz}$, 1H), $4.67(\mathrm{~s}, 1 \mathrm{H}), 4.46(\mathrm{t}, J=4.8 \mathrm{~Hz}, 2 \mathrm{H}), 3.82(\mathrm{t}, J=4.8 \mathrm{~Hz}, 2 \mathrm{H}), 3.69-3.57(\mathrm{~m}, 6 \mathrm{H})$, $2.66(\mathrm{dt}, J=8.2,6.5 \mathrm{~Hz}, 2 \mathrm{H}), 1.55(\mathrm{t}, J=8.2 \mathrm{~Hz}, 1 \mathrm{H}) ;{ }^{13} \mathrm{C} \mathrm{NMR}\left(\mathrm{CDCl}_{3}, 100 \mathrm{MHz}\right) \delta$ $166.7,138.3,132.6,131.93,130.9,126.0,124.7,73.0,70.7,70.3,69.2,64.3,24.4$. HRMS $\left(\mathrm{ESI}^{+}\right)$calcd for $\mathrm{C}_{13} \mathrm{H}_{18} \mathrm{O}_{4} \mathrm{~S}_{2}(\mathrm{M}+\mathrm{Na})^{+}$325.05442, obsd 325.0536, $(\mathrm{M}+\mathrm{H})^{+}$ 303.0724, obsd 303.0718.

2-[2-(2-(2-mercaptoethoxy)ethoxy)ethoxy]ethyl-2-mercaptobenzoate

[orthosubstituted aromatic tetraethylene glycol dithiol (12)]: $58 \%$ overall yield, ${ }^{1} \mathrm{H}$ NMR $\left(\mathrm{CDCl}_{3}, 400 \mathrm{MHz}\right) \delta 8.03(\mathrm{~d}, J=7.5 \mathrm{~Hz}, 1 \mathrm{H}), 7.31-7.29(\mathrm{~m}, 2 \mathrm{H}), 7.15(\mathrm{ddd}, J=8.1$, 5.6, $3.0 \mathrm{~Hz}, 1 \mathrm{H}), 4.70(\mathrm{~s}, 1 \mathrm{H}), 4.47(\mathrm{t}, J=4.8 \mathrm{~Hz}, 2 \mathrm{H}), 3.83(\mathrm{t}, J=4.8 \mathrm{~Hz}, 2 \mathrm{H}), 3.70-$

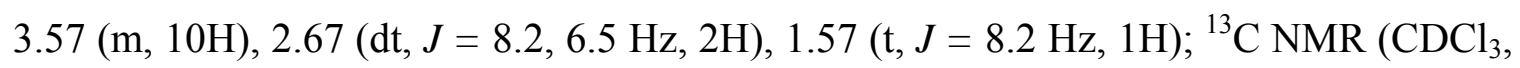
$100 \mathrm{MHz}) \delta$ 166.7, 138.7, 132.6, 132.0, 131.0, 126.1, 124.8, 73.0, 70.8, 70.8, 70.7, 70.4, 69.2, 64.4, 24.4. HRMS $\left(\right.$ ESI $\left.^{+}\right)$calcd for $\mathrm{C}_{15} \mathrm{H}_{22} \mathrm{O}_{5} \mathrm{~S}_{2}(\mathrm{M}+\mathrm{Na})^{+}$369.0806, obsd. 369.0788

2-(2-mercaptoethoxy)ethyl-4-mercaptobenzoate [para-substituted aromatic diethylene glycol dithiol (13)]: 95\% overall yield, ${ }^{1} \mathrm{H} \mathrm{NMR}\left(\mathrm{CDCl}_{3}, 400 \mathrm{MHz}\right) \delta 7.90$ (d, $J=8.4 \mathrm{~Hz}, 2 \mathrm{H}), 7.28(\mathrm{~d}, J=8.4 \mathrm{~Hz}, 2 \mathrm{H}), 4.45(\mathrm{t}, J=4.7 \mathrm{~Hz}, 2 \mathrm{H}), 3.79(\mathrm{t}, J=4.8 \mathrm{~Hz}$, $2 \mathrm{H}), 3.67-3.62(\mathrm{~m}, 2 \mathrm{H}), 2.70(\mathrm{dt}, J=8.1,6.3 \mathrm{~Hz}, 2 \mathrm{H}), 1.59(\mathrm{t}, J=8.2 \mathrm{~Hz}, 1 \mathrm{H}) ;{ }^{13} \mathrm{C}$ NMR $\left(\mathrm{CDCl}_{3}, 100 \mathrm{MHz}\right) \delta 166.1,138.7,130.4,128.2,127.1,72.9,69.0,64.1,24.4$. HRMS $\left(\mathrm{ESI}^{+}\right)$calcd for $\mathrm{C}_{11} \mathrm{H}_{14} \mathrm{O}_{3} \mathrm{~S}_{2}(\mathrm{M}+\mathrm{Na})^{+}$281.0282, obsd 281.0289. 
aromatic triethylene glycol dithiol (14)]: $59 \%$ overall yield, ${ }^{1} \mathrm{H}$ NMR $\left(\mathrm{CDCl}_{3}, 400\right.$ MHz) $\delta 7.90(\mathrm{~d}, J=8.4 \mathrm{~Hz}, 2 \mathrm{H}), 7.28(\mathrm{~d}, J=8.4 \mathrm{~Hz}, 2 \mathrm{H}), 4.46(\mathrm{t}, J=4.8 \mathrm{~Hz}, 2 \mathrm{H}), 3.83$ (t, $J=4.8 \mathrm{~Hz}, 2 \mathrm{H}), 3.71-3.60(\mathrm{~m}, 6 \mathrm{H}), 2.68(\mathrm{dt}, J=8.1,6.4 \mathrm{~Hz}, 2 \mathrm{H}), 1.58(\mathrm{t}, J=8.2$ $\mathrm{Hz}, 1 \mathrm{H}) ;{ }^{13} \mathrm{C} \mathrm{NMR}\left(\mathrm{CDCl}_{3}, 100 \mathrm{MHz}\right) \delta 166.1,138.6,130.4,128.2,127.1,73.0,70.7$, 70.3, 69.3, 64.1, 24.4. HRMS $\left(\right.$ ESI $\left.^{+}\right)$calcd for $\mathrm{C}_{13} \mathrm{H}_{18} \mathrm{O}_{4} \mathrm{~S}_{2}(\mathrm{M}+\mathrm{Na})^{+}$325.0544, obsd 325.0538, $\mathrm{C}_{13} \mathrm{H}_{18} \mathrm{O}_{4} \mathrm{~S}_{2}(\mathrm{M}+\mathrm{H})^{+}$303.0724, obsd 303.0721.

2-[2-(2-(2-mercaptoethoxy)ethoxy)ethoxy]ethyl-4-mercaptobenzoate [para substituted aromatic tetraethylene glycol dithiol (15)]: $68 \%$ overall yield, ${ }^{1} \mathrm{H}$ NMR $\left(\mathrm{CDCl}_{3}, 400 \mathrm{MHz}\right) \delta 7.90(\mathrm{~d}, J=8.4 \mathrm{~Hz}, 2 \mathrm{H}), 7.28(\mathrm{~d}, J=8.4 \mathrm{~Hz}, 2 \mathrm{H}), 4.45(\mathrm{t}, J=4.8$ $\mathrm{Hz}, 2 \mathrm{H}), 3.82(\mathrm{t}, J=4.8 \mathrm{~Hz}, 2 \mathrm{H}), 3.71-3.58(\mathrm{~m}, 10 \mathrm{H}), 2.68(\mathrm{dt}, J=8.1,6.5 \mathrm{~Hz}, 2 \mathrm{H})$, $1.59(\mathrm{t}, J=8.2 \mathrm{~Hz}, 1 \mathrm{H}) ;{ }^{13} \mathrm{C} \mathrm{NMR}\left(\mathrm{CDCl}_{3}, 100 \mathrm{MHz}\right) \delta 166.1,138.6,130.4,128.2$, 127.2, 73.0, 70.8, 70.8, 70.7, 70.3, 69.3, 64.2, 24.4. HRMS $\left(\mathrm{ESI}^{+}\right)$calcd for $\mathrm{C}_{15} \mathrm{H}_{22} \mathrm{O}_{5} \mathrm{~S}_{2}$ $(\mathrm{M}+\mathrm{Na})^{+} 369.0806$, obsd 369.0807.

3.3 Synthesis of aromatic triethylene glycol monothiol $(\mathbf{6 1})^{126}$

3.3.1 Synthesis of aromatic triethylene glycol disulfide (60)

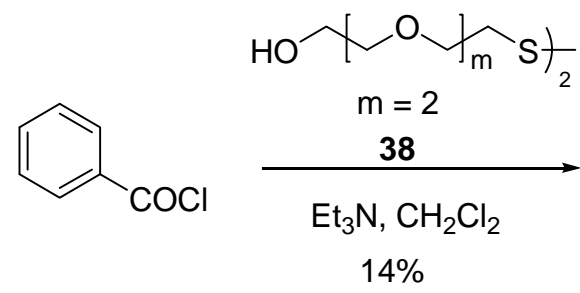

59

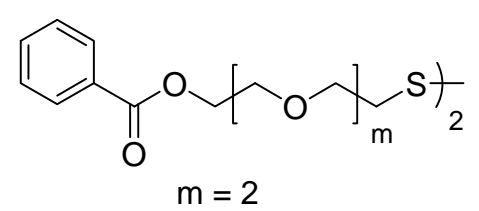

60

Benzoyl chloride (59) (0.646 g, $4.62 \mathrm{mmol}$ ) was dissolved in $20 \mathrm{~mL}$ of $\mathrm{CH}_{2} \mathrm{Cl}_{2}$ and then transferred to a flask containing triethylene glycol disulfide (38) $(0.763 \mathrm{~g}, 2.31$ 
mmol), $\mathrm{Et}_{3} \mathrm{~N}(0.964 \mathrm{~mL}, 6.93 \mathrm{mmol})$, and $10 \mathrm{~mL}$ of $\mathrm{CH}_{2} \mathrm{Cl}_{2}$ at $0{ }^{\circ} \mathrm{C}$. The reaction mixture was stirred at $0{ }^{\circ} \mathrm{C}$ for $30 \mathrm{~min}$ and then gradually warmed to room temperature, and stirring continued overnight. The reaction mixture was dissolved in $30 \mathrm{~mL} \mathrm{CH}_{2} \mathrm{Cl}_{2}$ and then washed with $50 \mathrm{~mL}$ of $0.1 \mathrm{~N} \mathrm{HCl}$. The organic layer was then washed with water (2 x $30 \mathrm{~mL})$, dried $\left(\mathrm{MgSO}_{4}\right)$, filtered, and reduced under pressure to give the crude oil. The crude oil was the purified by flash chromatography using 4:1 hexane:EtOAc to give 0.17 g of a yellow oil (60), 14\% yield.

${ }^{1} \mathrm{H}$ NMR $\left(\mathrm{CDCl}_{3}, 400 \mathrm{MHz}\right) \delta 8.05(\mathrm{~d}, J=7.1 \mathrm{~Hz}, 4 \mathrm{H}), 7.54(\mathrm{t}, J=7.4 \mathrm{~Hz}, 2 \mathrm{H}), 7.43(\mathrm{t} J$ $=7.9 \mathrm{~Hz}, 4 \mathrm{H}), 4.47(\mathrm{t}, J=4.8 \mathrm{~Hz}, 4 \mathrm{H}), 3.83(\mathrm{t}, J=4.9 \mathrm{~Hz}, 4 \mathrm{H}), 3.74-3.63(\mathrm{~m}, 12 \mathrm{H})$, $2.86(\mathrm{t}, J=6.7 \mathrm{~Hz}, 4 \mathrm{H})$.

\subsubsection{Synthesis of aromatic triethylene glycol monothiol (61)}

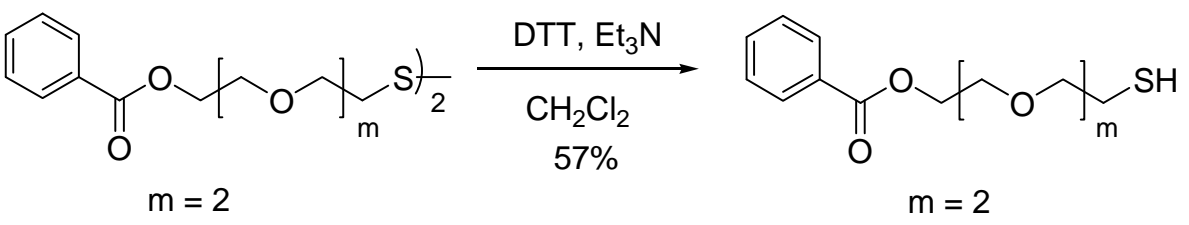

60

61

Triethylamine $(0.20 \mathrm{~mL}, 1.43 \mathrm{mmol})$ and DTT $(0.124 \mathrm{~g}, 0.315 \mathrm{mmol})$ were added to the disulfide $(\mathbf{6 0})(0.17 \mathrm{~g})$ in $15 \mathrm{~mL}$ of $\mathrm{CH}_{2} \mathrm{Cl}_{2}$. The reaction mixture was stirred for $2 \mathrm{~h}$ under argon and then the mixture was extracted with ethyl acetate. The organic layer was washed with water $(2 \times 25 \mathrm{~mL})$, dried over $\mathrm{MgSO}_{4}$, filtered, and concentrated under reduced pressure to give the crude product. The crude product was then purified by silica gel chromatography using $\mathrm{CH}_{2} \mathrm{Cl}_{2}$ to give $0.097 \mathrm{~g}$ of aromatic triethylene glycol monothiol (61) as an yellow oil, 57\% overall yield. 
${ }^{1} \mathrm{H}$ NMR $\left(\mathrm{CDCl}_{3}, 400 \mathrm{MHz}\right) \delta 8.04(\mathrm{~d}, J=7.0 \mathrm{~Hz}, 2 \mathrm{H}), 7.55(\mathrm{t}, J=7.4 \mathrm{~Hz}, 1 \mathrm{H}), 7.42(\mathrm{t} J$ $=7.7 \mathrm{~Hz}, 2 \mathrm{H}), 4.47(\mathrm{t}, J=4.8 \mathrm{~Hz}, 2 \mathrm{H}), 3.83(\mathrm{t}, J=3.7 \mathrm{~Hz}, 2 \mathrm{H}), 3.70(\mathrm{t}, J=4.0 \mathrm{~Hz}, 2 \mathrm{H})$, $3.65-3.58(\mathrm{~m}, 4 \mathrm{H}), 2.66(\mathrm{q}, J=6.4 \mathrm{~Hz}, 2 \mathrm{H}), 1.55(\mathrm{t}, J=8.2 \mathrm{~Hz}, 1 \mathrm{H}) ;{ }^{13} \mathrm{C} \mathrm{NMR}\left(\mathrm{CDCl}_{3}\right.$, $100 \mathrm{MHz}) \delta$ 166.6, 133.1, 130.2, 129.8, 128.4, 73.0, 70.8, 70.4, 69.4, 64.2, 24.4. HRMS $\left(\mathrm{ESI}^{+}\right)$calcd for $\mathrm{C}_{13} \mathrm{H}_{18} \mathrm{O}_{4} \mathrm{~S}(\mathrm{M}+\mathrm{Na})^{+}$293.08235, obsd 293.08230.

\subsection{Synthesis of Di quaternary salt dithiols (Di QAS 16 and 17)}

\subsubsection{Synthesis of $N^{1}, N^{3}$-bis(4-benzoylthio)benzyl)- $N^{1}, N^{1}, N^{3}, N^{3}$-tetramethylpropane-} 1,3-diaminium bromide (67) $)^{127}$<smiles>O=C(Sc1ccc(CBr)cc1)c1ccccc1</smiles>

25

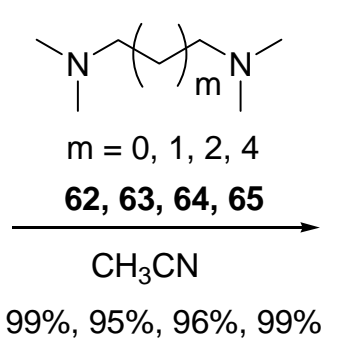

99\%, 95\%, 96\%, 99\%

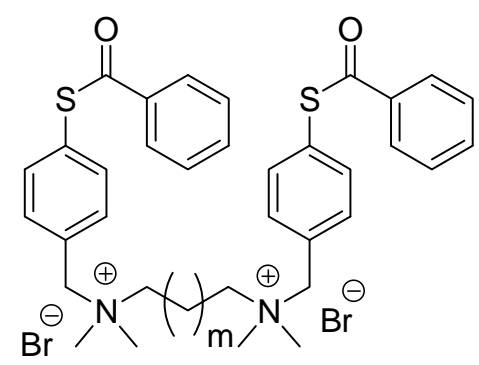

$m=0,1,2,4$

$66,67,68,69$

\section{General procedure}

Benzyl bromide derivative (25) $(2.10 \mathrm{~g}, 6.84 \mathrm{mmol})$ was added to a stirred solution of $N, N, N^{\prime}, N^{\prime}$-tetramethyl-1,3-propane diamine (63) (0.38 g, $\left.2.92 \mathrm{mmol}\right)$ in $20 \mathrm{~mL}$ of acetonitrile. The reaction mixture was stirred overnight, then the slurry was diluted with diethyl ether, filtered, washed with diethyl ether, and dried yielding $2.07 \mathrm{~g}$ of a white powder (67), 95\% yield.

$N^{1}, N^{2}$-bis(4-benzoylthio)benzyl)- $N^{1}, N^{1}, N^{2}, N^{2}$-tetramethylethane-1,2-diaminium

bromide [TMEDA Salt (66)]: 99\% yield, ${ }^{1} \mathrm{H}$ NMR (DMSO, $\left.400 \mathrm{MHz}\right) \delta 8.00(\mathrm{~d}, J=$ 
$7.5 \mathrm{~Hz}, 4 \mathrm{H}), 7.82-7.72(\mathrm{~m}, 10 \mathrm{H}), 7.62(\mathrm{t}, J=7.8 \mathrm{~Hz}, 4 \mathrm{H}), 4.82(\mathrm{~s}, 4 \mathrm{H}), 4.16(\mathrm{~s}, 4 \mathrm{H})$, 3.17 (s, 12H). ${ }^{13} \mathrm{C}$ NMR (DMSO, $\left.100 \mathrm{MHz}\right) \delta 188.4,135.6,135.2,134.6,134.0,129.8$, $129.4,128.8,127.1,66.7,55.8,49.8$.

$N^{1}, N^{3}$-bis(4-benzoylthio)benzyl)- $N^{1}, N^{1}, N^{3}, N^{3}$-tetramethylpropane-1,3-diaminium bromide [Propane salt (67)]: 95\% yield, ${ }^{1} \mathrm{H}$ NMR (DMSO, $\left.400 \mathrm{MHz}\right) \delta 8.00(\mathrm{~d}, J=7.4$ Hz, 4H), $7.78-7.70(\mathrm{~m}, 10 \mathrm{H}), 7.62$ (t, $J=7.8 \mathrm{~Hz}, 4 \mathrm{H}), 4.74(\mathrm{~s}, 4 \mathrm{H}), 3.37$ (t, $J=8.0 \mathrm{~Hz}$, $4 \mathrm{H}), 3.11$ (s, 12H), $2.50-2.46(\mathrm{~m}, 2 \mathrm{H}) .{ }^{13} \mathrm{C}$ NMR (DMSO, $\left.100 \mathrm{MHz}\right) \delta$ 188.6, 135.7, 135.2, 134.6, 134.0, 129.6, 129.5, 129.3, 127.2, 66.5, 60.1, 49.7, 16.9. HRMS $\left(\mathrm{ESI}^{+}\right)$ calcd for $\mathrm{C}_{35} \mathrm{H}_{40} \mathrm{Br}_{2} \mathrm{~N}_{2} \mathrm{O}_{2} \mathrm{~S}_{2}(\mathrm{M}-\mathrm{Br})^{+}$663.1714, obsd 663.1685.

$N^{1}, N^{4}$-bis(4-benzoylthio)benzyl)- $N^{1}, N^{1}, N^{4}, N^{4}$-tetramethylbutane-1,4-diaminium bromide [Butane salt (68)]: 96\% yield, ${ }^{1} \mathrm{H}$ NMR (DMSO, $\left.400 \mathrm{MHz}\right) \delta 7.99(\mathrm{~d}, J=7.2$ Hz, 4H), 7.79 - 7.70 (m, 10H), 7.62 (t, J = $7.9 \mathrm{~Hz}, 4 \mathrm{H}), 4.66$ (s, 4H), 3.39 (brs, 4H), 3.04 (s, 12H), 1.84 (brs, 4H). ${ }^{13} \mathrm{C}$ NMR (DMSO, $\left.100 \mathrm{MHz}\right) \delta 188.4,135.6,135.2,134.5$, $133.8,129.5,129.4,129.4,127.1,66.1,62.6,49.4,19.3$. HRMS $\left(\mathrm{ESI}^{+}\right)$calcd for $\mathrm{C}_{36} \mathrm{H}_{42} \mathrm{Br}_{2} \mathrm{~N}_{2} \mathrm{O}_{2} \mathrm{~S}_{2}(\mathrm{M}-\mathrm{Br})^{+}$677.1871, obsd 677.1849 $N^{1}, N^{6}$-bis(4-benzoylthio)benzyl)- $N^{1}, N^{1}, N^{6}, N^{6}$-tetramethylhexane-1,6-diaminium bromide [Hexane salt (69)]: 99\% yield, ${ }^{1} \mathrm{H}$ NMR (DMSO, $\left.400 \mathrm{MHz}\right) \delta 7.99(\mathrm{~d}, J=7.3$ Hz, 4H), 7.79 - 7.69 (m, 10H), 7.62 (t, $J=7.9 \mathrm{~Hz}, 4 \mathrm{H}), 4.67$ (s, 4H), 3.33 (brs, 4H), 3.03 (s, 12H), 2.07 (brs, 4H), 1.38 (brs, 4H). ${ }^{13} \mathrm{C}$ NMR (DMSO, $\left.100 \mathrm{MHz}\right) \delta$ 188.5, 135.6, 135.1, 134.5, 133.8, 129.5, 129.3, 127.1, 65.5, 63.5, 49.3, 25.3, 21.7. HRMS $\left(\mathrm{ESI}^{\dagger}\right)$ calcd for $\mathrm{C}_{38} \mathrm{H}_{46} \mathrm{Br}_{2} \mathrm{~N}_{2} \mathrm{O}_{2} \mathrm{~S}_{2}(\mathrm{M}-\mathrm{Br})^{+}$705.2184, obsd 705.2163. 
3.4.2 Synthesis of $N^{1}, N^{3}$-bis(4-mercaptobenzyl)- $N^{1}, N^{1}, N^{3}, N^{3}$-tetramethylpropane-1,3diaminium bromide (Di QAS 16)
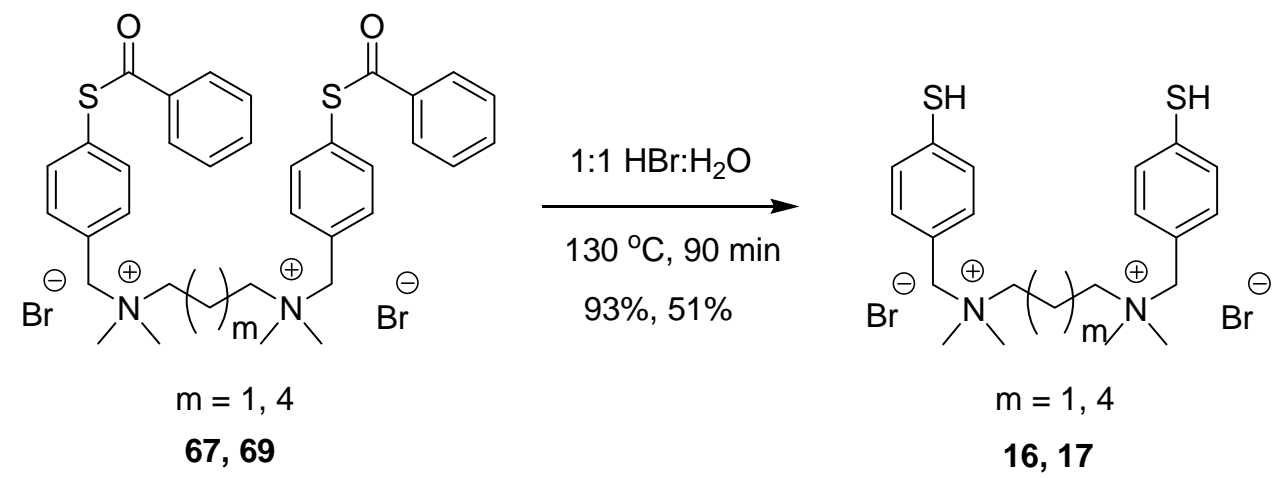

16,17

\section{General procedure}

The di quaternary ammonium salt (67) $(1.557 \mathrm{~g}, 2.09 \mathrm{mmol})$ dissolved in $45 \mathrm{~mL}$ of water and $45 \mathrm{~mL}$ of $\mathrm{HBr}\left(48 \mathrm{wt} \%\right.$ in water) was refluxed under argon at $130^{\circ} \mathrm{C}$. After $90 \mathrm{~min}$, the reaction mixture was cooled to $0{ }^{\circ} \mathrm{C}$, filtered, and then washed with EtOAc (3 $\mathrm{x} 100 \mathrm{~mL}$ ). The aqueous layer was reduced partially and then lyophilized several times by dissolving the residue in water to give $1.042 \mathrm{~g}$ of Di QAS $\mathbf{1 6}$ as a white powder, $93 \%$ yield.

$N^{1}, N^{3}$-bis(4-mercaptobenzyl)- $N^{1}, N^{1}, N^{3} N^{3}$-tetramethylpropane-1,3-diaminium bromide (Di QAS 16): 93\% yield, ${ }^{1} \mathrm{H}$ NMR $\left(\mathrm{D}_{2} \mathrm{O}, 400 \mathrm{MHz}\right) \delta 7.46(\mathrm{~d}, J=8.4 \mathrm{~Hz}, 4 \mathrm{H})$, $7.41(\mathrm{~d}, J=8.4 \mathrm{~Hz}, 4 \mathrm{H}), 4.52(\mathrm{~s}, 4 \mathrm{H}), 3.37(\mathrm{t}, J=8.3 \mathrm{~Hz}, 4 \mathrm{H}), 3.09(\mathrm{~s}, 12 \mathrm{H}), 2.41$ (quintet, $J=8.3 \mathrm{~Hz}, 2 \mathrm{H}) .{ }^{13} \mathrm{C} \mathrm{NMR}\left(\mathrm{D}_{2} \mathrm{O}, 100 \mathrm{MHz}\right) \delta 135.8,133.5,129.0,123.5,68.5$, 60.1, 49.7, 17.0. HRMS $\left(\mathrm{ESI}^{+}\right)$calcd for $\mathrm{C}_{21} \mathrm{H}_{32} \mathrm{Br}_{2} \mathrm{~N}_{2} \mathrm{~S}_{2}(\mathrm{M}-\mathrm{Br})^{+}$455.1190, obsd 455.1175.

$N^{1}, N^{6}$-bis(4-mercaptobenzyl)- $N^{1}, N^{1}, N^{3} N^{6}$-tetramethylhexane-1,3-diaminium 
bromide (Di QAS 17): 51\% yield, ${ }^{1} \mathrm{H}$ NMR $\left(\mathrm{D}_{2} \mathrm{O}, 400 \mathrm{MHz}\right) \delta 7.50(\mathrm{~d}, J=7.2 \mathrm{~Hz}, 4 \mathrm{H})$, 7.45 (d, $J=7.7 \mathrm{~Hz}, 4 \mathrm{H}), 4.48(\mathrm{~s}, 4 \mathrm{H}), 3.30(\mathrm{t}, J=8.0 \mathrm{~Hz}, 4 \mathrm{H}), 3.08(\mathrm{~s}, 12 \mathrm{H}), 1.92$ (brs, 4H), 1.47 (brs, 4H). ${ }^{13} \mathrm{C}$ NMR $\left(\mathrm{D}_{2} \mathrm{O}, 100 \mathrm{MHz}\right) \delta 135.3,133.4,128.9,124.1,67.4,63.8$, 49.6, 25.2, 22.0. HRMS $\left(\mathrm{ESI}^{+}\right)$calcd for $\mathrm{C}_{24} \mathrm{H}_{38} \mathrm{Br}_{2} \mathrm{~N}_{2} \mathrm{~S}_{2}(\mathrm{M}-\mathrm{Br})^{+}$497.1659, obsd 497.1638.

\subsection{Enzymatic assays}

\subsubsection{Preparation of reduced denatured lysozyme}

Lysozyme $(20 \mathrm{mg} / \mathrm{mL})$ was dissolved in $0.1 \mathrm{M}$ Tris- $\mathrm{HCl}$ at $\mathrm{pH} 8.6$ which contained $6 \mathrm{M} \mathrm{Gdn} \mathrm{HCl}$ and $0.15 \mathrm{M}$ dithioerythritol (DTE). The protein solution was incubated for $2 \mathrm{~h}$ at room temperature and then acidified with glacial acetic acid to $\mathrm{pH}$ $3{ }^{59,128}$ The solution was then applied to a column packed with Sephadex G-25 that has been pre-equilibrated with $0.1 \mathrm{M}$ acetic acid. The fractions that contained reduced lysozyme, as determined by Ellman's reagent [100 mg of (5,5'-dithiol-bis(2-nitrobenzoic acid)) was dissolved in $25 \mathrm{~mL}$ of $0.2 \mathrm{M}$ Tris- $\mathrm{HCl}, \mathrm{pH} 8.0$, and $25 \mathrm{~mL}$ of ethanol], were collected and mixed together in a $50 \mathrm{~mL}$ centrifuge tube. The fractions containing DTE, which eluted from the column after the protein, were discarded. The reduced protein concentration was determination by its absorbance at $280 \mathrm{~nm}$ using a Cary $300 \mathrm{UV}$ visible spectrophotometer $\left(\varepsilon_{280 \mathrm{~nm}}=2.37 \mathrm{~mL} \mathrm{mg}^{-1} \mathrm{~cm}^{-1}\right) .{ }^{129}$ The reduced lysozyme showed no enzymatic activity. The reduced lysozyme was stored at $-20{ }^{\circ} \mathrm{C}$ as a solid after the removal of solvent by lyophilization.

\subsubsection{Calibration of assay for native lysozyme}

Native lysozyme was dissolved in $\mathrm{Gdn} \mathrm{HCl}$ buffer (6 M Gdn $\mathrm{HCl}$ dissolved in 0.1 $\mathrm{M}$ acetic acid) to prepare a stock solution of native lysozyme (approx. $1 \mathrm{mg} / \mathrm{mL}$ ). The 
concentration of the stock solution was determined spectrophotometrically by measuring the absorbance at $280 \mathrm{~nm}\left(\varepsilon_{280 \mathrm{~nm}}=2.63 \mathrm{~mL} \mathrm{mg}^{-1} \mathrm{~cm}^{-1}\right) .{ }^{129,130}$ The stock solution of native lysozyme was then used to prepare solutions of various concentrations, from $0.01 \mathrm{mg} / \mathrm{mL}$ to $0.1 \mathrm{mg} / \mathrm{mL}$. The enzymatic assay (vide infra) was then used to determine the activity of each solution. The activity was then plotted against native protein concentration. It was observed that the rate varied linearly with respect to protein concentration.

\subsubsection{Assay for lysozyme activity ${ }^{129,131,132}$}

In order to measure the lysozyme activity in all cases, a $20 \mu \mathrm{L}$ aliquot of native or renatured lysozyme solution $(0.1 \mathrm{mg} / \mathrm{mL})$ was mixed with $980 \mu \mathrm{L}$ of $M$. Lysodeikticus solution $(0.25 \mathrm{mg} / \mathrm{mL})$ in $66 \mathrm{mM}$ monobasic potassium phosphate, $\mathrm{pH}$ 6.2, equilibrated at $25{ }^{\circ} \mathrm{C}$. The cuvette was inverted repeatedly for $15 \mathrm{~s}$ to ensure proper mixing of the samples, and then light scattering at $450 \mathrm{~nm}$ was monitored for $2 \mathrm{~min}$. The lytic activity of lysozyme was determined from the slope of the line.

\subsubsection{Refolding of denatured reduced lysozyme $(0.1 \mathrm{mg} / \mathrm{mL})$}

Reduced lysozyme $(10 \mathrm{mg} / \mathrm{mL})$ was dissolved in $0.1 \mathrm{M}$ acetic acid containing 6 M Gdn HCl at $\mathrm{pH} 2.5\left(\varepsilon_{280 \mathrm{~nm}}=2.37 \mathrm{~mL} \mathrm{mg}^{-1} \mathrm{~cm}^{-1}\right){ }^{59,129,131}$ The $\mathrm{pH}$ of the stock solutions containing the thiol or disulfide were also adjusted to the appropriate $\mathrm{pH}(7.0$ or 8.0$)$ with $1 \mathrm{M} \mathrm{KOH}$ prior to use. Refolding of reduced lysozyme was carried out in a deoxygenated renaturation buffer $[0.1 \mathrm{M}$ bis tris propane- $\mathrm{HCl}, \mathrm{pH} 7.0,1 \mathrm{mM}$ EDTA, and 0.5 M Gdn $\mathrm{HCl}$ or $0.1 \mathrm{M}$ Tris- $\mathrm{HCl}, \mathrm{pH} 8.0,1 \mathrm{mM}$ EDTA, and $0.5 \mathrm{M} \mathrm{Gdn} \mathrm{HCl}$, and various concentrations of GSH or aromatic dithiols, and GSSG or aromatic disulfide]. In a 1.5 mL-Eppendorf tube, $10 \mu \mathrm{L}$ of reduced lysozyme $(10 \mathrm{mg} / \mathrm{mL})$ was added to $990 \mu \mathrm{L}$ of 
renaturation buffer (100-fold dilution). For reproducible mixing conditions, the renaturation buffer was placed in an Eppendorf tube, the protein was added as a droplet on the wall of the tube above the buffer meniscus, and mixing was achieved by vigorous agitation with a vortex mixer for $15 \mathrm{~s}$. Subsequently, $20 \mu \mathrm{L}$ aliquots were removed at specific times and assayed for enzymatic activity. All the refolding experiments were performed at $25^{\circ} \mathrm{C}$.

\subsubsection{Refolding of denatured reduced lysozyme $(1 \mathrm{mg} / \mathrm{mL})$}

Reduced lysozyme $(11 \mathrm{mg} / \mathrm{mL})$ was dissolved in $0.1 \mathrm{M}$ acetic acid containing 6 $\mathrm{M} \mathrm{Gdn} \mathrm{HCl}$ at $\mathrm{pH} 2.5$. The $\mathrm{pH}$ of the protein solution was then adjusted to that of the folding experiment ( $\mathrm{pH} 7.0$ or 8.0) by the addition of $3 \mathrm{M} \mathrm{KOH}$. After adjusting the $\mathrm{pH}$, the concentration of the protein solution was determined by UV-vis, and the final concentration was adjusted to $10 \mathrm{mg} / \mathrm{mL}$ with $6 \mathrm{M} \mathrm{Gdn} \mathrm{HCl}$, if necessary $\left(\varepsilon_{280 \mathrm{~nm}}=2.37\right.$ $\left.\mathrm{mL} \mathrm{mg}^{-1} \mathrm{~cm}^{-1}\right) .^{59,129,131}$ Stock solutions of GSH, aromatic monothiols, aromatic dithiols, and GSSG were prepared in deoxygenated $0.1 \mathrm{M}$ bis tris propane- $\mathrm{HCl}$ (for $\mathrm{pH} 7.0$ ) or 0.1 $\mathrm{M}$ Tris- $\mathrm{HCl}$ (for $\mathrm{pH} 8.0$ ), $1.25 \mathrm{M} \mathrm{Gdn} \mathrm{HCl}$, and $1 \mathrm{mM}$ EDTA. From the stock solutions, varying amount of GSH and GSSG, aromatic monothiol and GSSG, or aromatic dithiols and GSSG were mixed in $0.1 \mathrm{M}$ bis tris propane- $\mathrm{HCl}$ at $\mathrm{pH} 7.0$ or $0.1 \mathrm{M}$ Tris- $\mathrm{HCl}$ at $\mathrm{pH}$ 8.0, 1.25 $\mathrm{M} \mathrm{Gdn} \mathrm{HCl}$, and $1 \mathrm{mM}$ EDTA and adjusted to the appropriate $\mathrm{pH}$ with $1 \mathrm{M}$ $\mathrm{KOH}$, if necessary (renaturation buffer). In a $1.5 \mathrm{~mL}-$ Eppendorf tube, $900 \mu \mathrm{L}$ of renaturation buffer was mixed with $100 \mu \mathrm{L}$ of reduced lysozyme solution $(10 \mathrm{mg} / \mathrm{mL})$ to give a 10 fold dilution. Subsequently, at specific intervals, $10 \mu \mathrm{L}$ of aliquots were withdrawn and diluted with $90 \mu \mathrm{L}$ of buffer $(0.1 \mathrm{M}$ bis tris propane- $\mathrm{HCl}$ at $\mathrm{pH} 7.0$ or 0.1 
$\mathrm{M}$ Tris- $\mathrm{HCl}$ at $\mathrm{pH} 8.0,1.25 \mathrm{M} \mathrm{Gdn} \mathrm{HCl}$, and $1 \mathrm{mM}$ EDTA) followed by withdrawing 20 $\mu \mathrm{L}$ of the resulting solution and then measuring the enzymatic activity.

\subsection{Determination of pKa values (UV-Vis method) ${ }^{133,134}$}

Twenty four buffers $(50 \mathrm{mM})$ at a range of $\mathrm{pH}$ values: glycine, $\mathrm{pH}$ 2.5, 3.0, 3.3; 2,2-dimethoxysuccinate, $\mathrm{pH} 3.7,4.0,4.3,4.7,5.0,5.3,5.7,6.0,6.3,6.7$; Tris, $\mathrm{pH}$ 7.0, 7.3, 7.7, 8.0, 8.3, 8.7; glycine, $\mathrm{pH} 9.0,9.5,10.0,10.5 ; \mathrm{H}_{3} \mathrm{PO}_{4}, \mathrm{pH} 11.0$ were prepared. An ethanolic solution (100 mM) of the aromatic thiol or dithiol was diluted by $100-1000$ fold using a high or low $\mathrm{pH}$ buffer until the absorbance was 1.5. Then the absorbance of the given aromatic thiol or dithiol was measured in buffers whose $\mathrm{pH}$ would fall within 1.5 units of the $\mathrm{pK}_{\mathrm{a}}$ of the thiol tested. The absorbance of the selected thiol or dithiol in each buffers was measured at the $\lambda_{\max }$, of the corresponding thiolate or thiol. The absorbance was plotted against the $\mathrm{pH}$ and then compared with a plot derived from theory. The $\mathrm{pK}_{\mathrm{a}}$ was determined from the best fit curve. 


\section{Chapter 4}

\section{Results and discussion}

Results and discussion will be divide into four section.

1) The synthesis of aromatic monothiols and their corresponding disulfides will be described. Additionally, the folding of bovine pancreatic trypsin inhibitor (by Ms. Shweta Mandumula) and the folding of lysozyme (by Dr. David Madar) using aromatic monothiols and their corresponding disulfides will be presented.

2) The synthesis of ortho- and para-substituted aromatic ethylene glycol dithiols and their effect on the folding of lysozyme $(0.1 \mathrm{mg} / \mathrm{mL})$ will be discussed.

3) The synthesis of quaternary ammonium aromatic dithiols and the activity of these compounds on the folding of lysozyme $(1 \mathrm{mg} / \mathrm{mL})$ will be discussed.

4) The thiol $\mathrm{pK}_{\mathrm{a}}$ values of aromatic monothiols and dithiols will be presented.

\subsection{Synthesis of aromatic monothiols (1-4) and their corresponding disulfides (5-8), and their folding studies}

Initially, a series of aromatic monothiols with a range of thiol $\mathrm{pK}_{\mathrm{a}}$ values, such as 4-mercaptobenzoic acid (1), 4-mercaptobenzylphosphonic acid (2), quaternary ammonium salt (3), and 4-mercaptobenzenesulfonic acid (4), and their corresponding disulfides (5-8) were synthesized. The above compounds were synthesized on a multigram scale in 4-5 steps. Compounds 1-4 were selected on the basis of their thiol $\mathrm{pK}_{\mathrm{a}}$ values (5-7) and water solubility $(>10 \mathrm{mM})$. The $\mathrm{pK}_{\mathrm{a}}$ value of the aromatic thiols were expected to be similar to that of PDI. ${ }^{135}$ As most protein folding assays are performed in aqueous media close to neutral $\mathrm{pH}$, the aromatic thiols selected were expected to be soluble at pH 7 in both the thiol and disulfide form. 


\subsubsection{Synthesis of 4-mercaptobenzoic acid (1) and its disulfide (5)}

The synthesis of 4-mercaptobenzoic acid (1) was performed from readily available methyl 4-hydroxybenzoate (18). Methyl 4-hydroxybenzoate (18) on treatment with DABCO and $N, N$-dimethylthiocarbamoyl chloride (19) gave compound (20) which on heating at $210-240{ }^{\circ} \mathrm{C}$ underwent rearrangement to form compound (21). Next, compound (21) was hydrolyzed by treating with $\mathrm{NaOH}$ and methanol to give 4mercaptobenzoic acid (1) (Scheme 3). The disulfide of 4-mercaptobenzoic acid (5) was synthesized by dissolving 4-mercaptobenzoic (1) acid in ethanol and adding a saturated solution of $\mathrm{I}_{2}$ in $95 \%$ ethanol until a light yellow color persisted. The mixture was filtered to give 4-mercaptobenzoic acid disulfide (5) as an off white solid (Scheme 3).
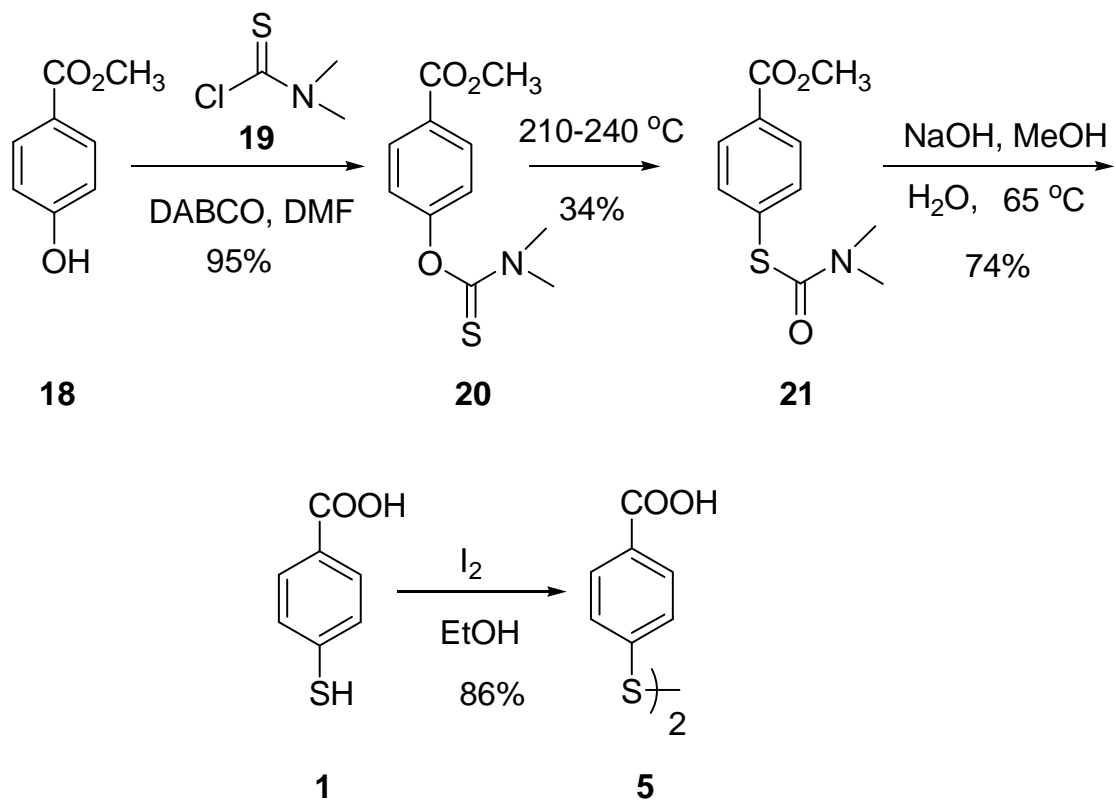

Scheme 3. Synthesis of 4-mercaptobenzoic acid (1) and its disulfide (5)

\subsubsection{Synthesis of 4-mercaptobenzylphosphonic acid (2)}

The 4-mercaptobenzylphosphonic acid (2) and quaternary ammonium salt (3) were synthesized through a common intermediate, bromo derivative (25). 4- 
Mercaptobenzylphosphonic acid (2) was synthesized by treating $p$-toluene thiol (22) with benzoyl chloride (23) to form compound (24). Compound (24) was then treated with $\mathrm{N}$ bromosuccimide to form bromo derivative (25) which on treatment with triethylphosphite produced phosphonic acid derivative (26). Previously, phosphonic acid derivative (26) was purified by column chromatography followed by recrystallization. I improved upon this method by cooling the reaction mixture to $-5^{\circ} \mathrm{C}$, which precipitated out the product. The solid residue was then recrystallized to yield the phosphonic acid (26). By avoiding the column chromatography step, I saved time, improved the yield, and was able to perform the reaction on a large scale. Phosphonic acid derivative (26) was then reacted
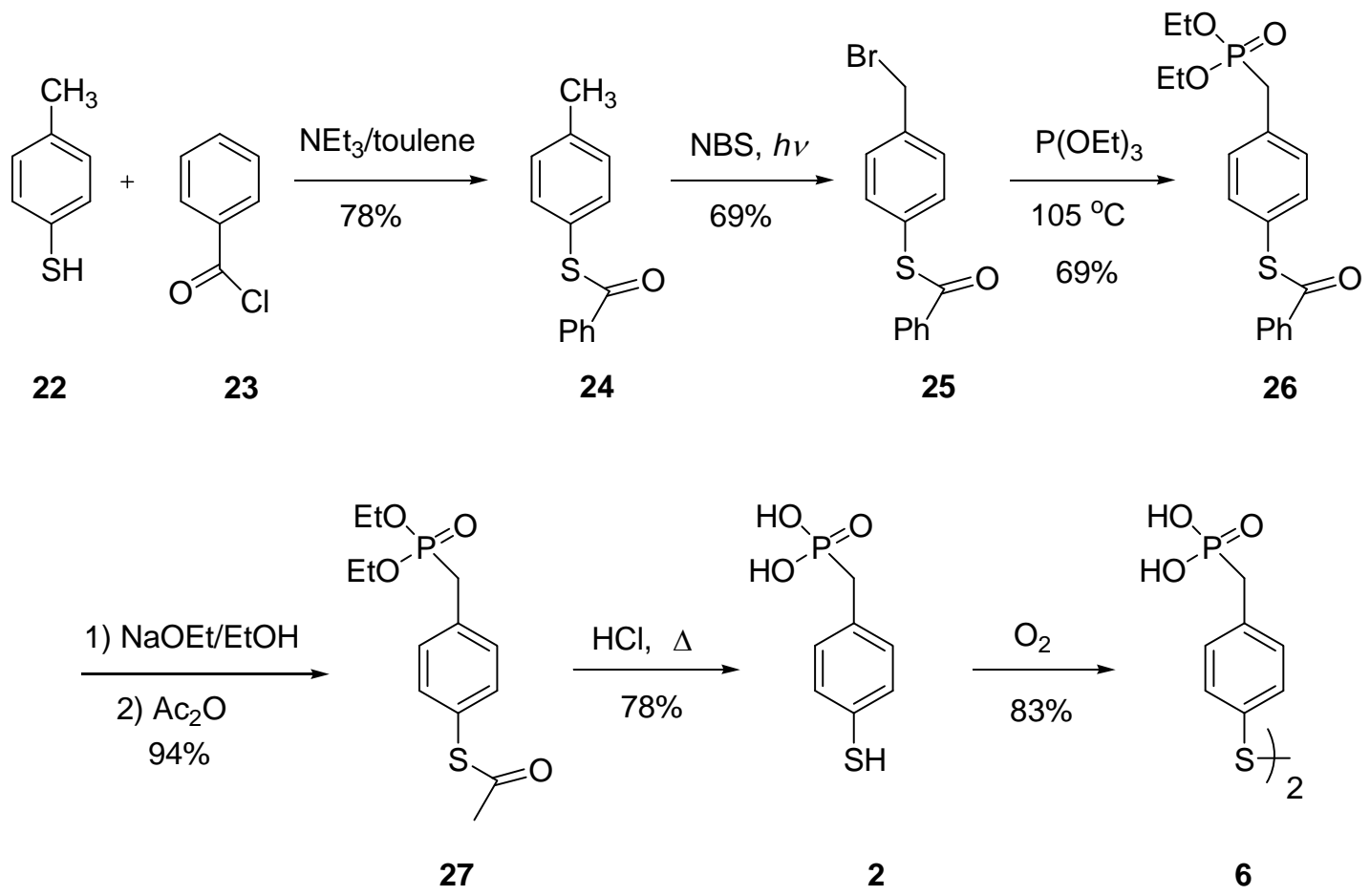

Scheme 4. Synthesis of 4-mercaptobenzylphosphonic acid (2) and its disulfide (6)

with sodium ethoxide/ethanol followed by acetic anhydride to change the benzoyl protecting group to an acetyl protecting group, thus preventing benzoic acid from precipitating out of the solution along with the 4-mercaptobenzylphosphonic acid (2) in 
the next step. Next, the acetyl protected group was hydrolyzed by refluxing with conc $\mathrm{HCl}$ to give 4-mercaptobenzylphosphonic acid (2) (Scheme 4). The disulfide of 4mercaptobenzylphosphonic acid (6) was synthesized for the first time by vigorously stirring the corresponding thiol (2) in water for 1 week (Scheme 4).

\subsubsection{Synthesis of quaternary ammonium thiol salt (Mono QAS 3) and its disulfide 7}

Mono QAS 3 was synthesized from bromo derivative (25), one of the intermediates in the synthesis of 4-mercaptobenzylphosphonic acid (2). The bromo derivative (25) was reacted with trimethylamine to form quaternary ammonium salt (28) in $81 \%$ yield, which on hydrolysis with conc $\mathrm{HBr}: \mathrm{H}_{2} \mathrm{O}(1: 5)$ gave quaternary ammonium thiol (3) in quantitative yield (Scheme 5). The disulfide of the quaternary ammonium salt (7) was synthesized by vigorously stirring the corresponding thiol (3) in water for 6 months (Scheme 5).

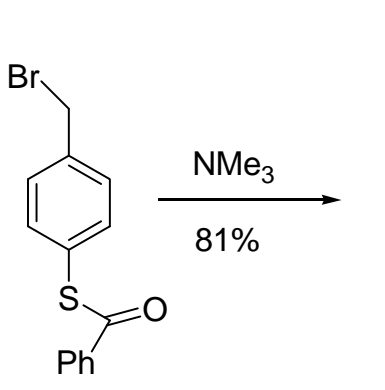

25

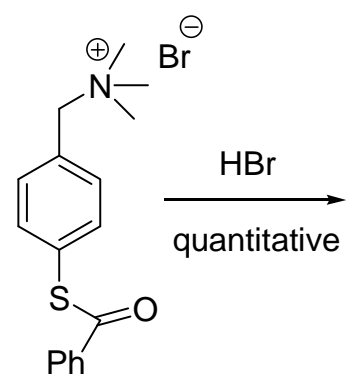

28

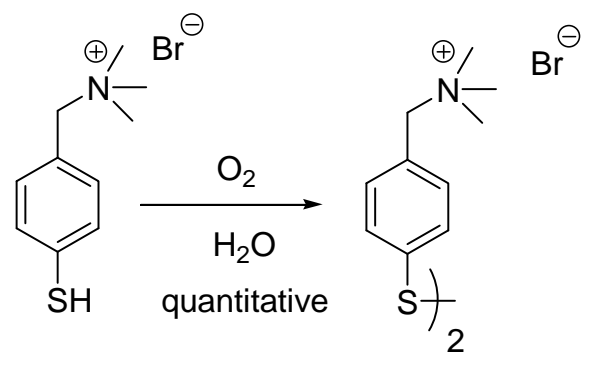

3
7

Scheme 5. Synthesis of Mono QAS (3) and its disulfide (7)

\subsubsection{Synthesis of 4-mercaptobenzenesulfonic acid (4) and its disulfide (8)}

The 4-Mercaptobenzenesulfonic acid (4) was synthesized from readily available 4-aminobenzenesulfonic acid (29). 4-Aminobenzenesulfonic acid (29) was dissolved in a solution of $\mathrm{NaOH}$ in water, and then conc $\mathrm{HCl}$ was added. To the resulting suspension, a 
solution of sodium nitrite in water was added, and the mixture was poured into a solution of sodium disulfide. The insoluble material was filtered off and a solution of aniline and conc $\mathrm{HCl}$ in water was added to the filtrate. The precipitate was filtered, recrystallized

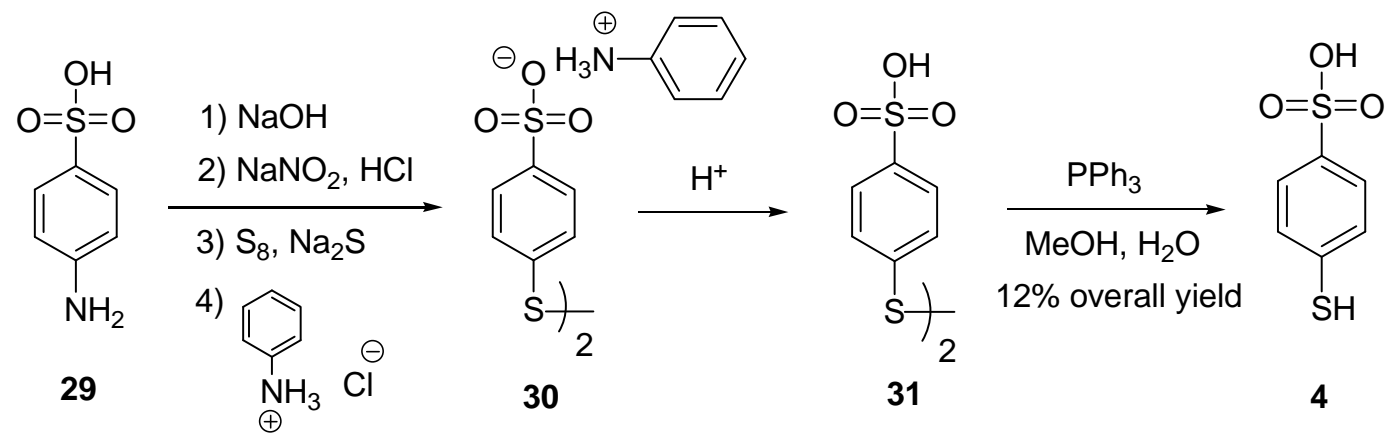<smiles>O=S(=O)([O-])c1ccc(S(=O)(=O)[O-])cc1</smiles>

Scheme 6. Synthesis of 4-mercaptobenzenesulfonic acid (4) and disulfide of Na salt of 4mercaptobenzenesulfonic acid (8)

from water, and washed with ethanol and hexane to give the dianilinium salt (30). The dianilinium ions (30) were exchanged for hydrogen ions by ion exchange chromatography, and then the disulfide (31) was reduced by treating with triphenylphosphine in the presence of water and methanol to form 4mercaptobenzenesulfonic acid (4) (Scheme 6). The disulfide of 4mercaptobenzenesulfonic acid (8) was formed as its sodium salt by exchanging the anilinium ions (30) with sodium ions by ion exchange chromatography (Scheme 6 ). 


\subsubsection{Folding studies with aromatic monothiols and their disulfides}

\subsubsection{Folding of BPTI in the presence of GSSG, phosphonic acid disulfide (6),}

quaternary ammonium salt disulfide (7), and sulfonic acid disulfide (8)

A folding intermediate of BPTI, $\mathrm{N}^{*}$, was folded in the presence of various concentrations of GSSG and more reactive small molecule aromatic disulfides (6), (7), and (8) by Ms. Shweta Mandumula (Figure 18 a-c). It was observed that the folding rate increased as the thiol $\mathrm{pK}_{\mathrm{a}}$ of the corresponding thiol decreased. As aromatic thiols have lower thiol $\mathrm{pK}_{\mathrm{a}}$ values, aromatic thiols act as better leaving group than GSH during thiol/disulfide interchange reactions. It was also observed that by increasing the disulfide concentration the folding rate of $\mathrm{N}^{*}$ increased.

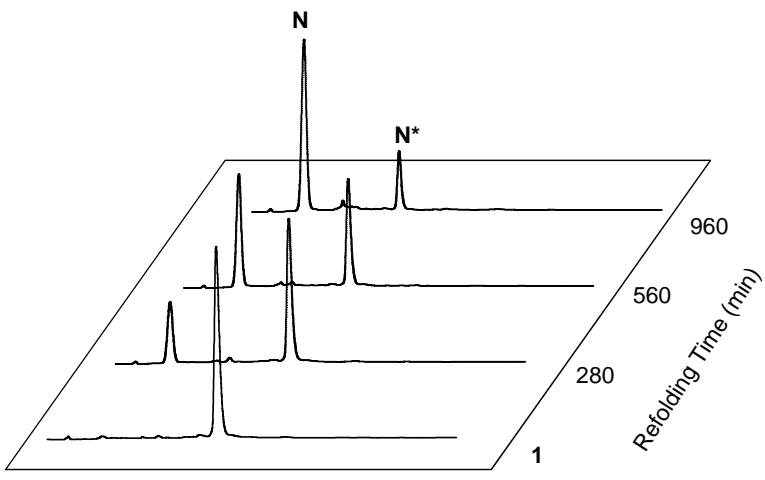

a)

Retention Time (min)

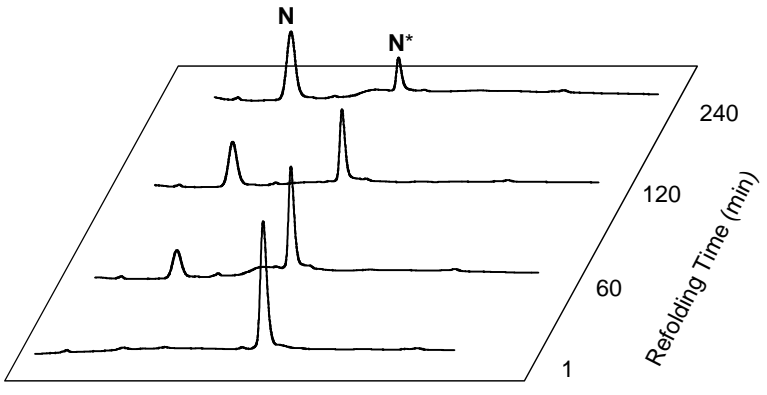

b)

Retention Time (min) 


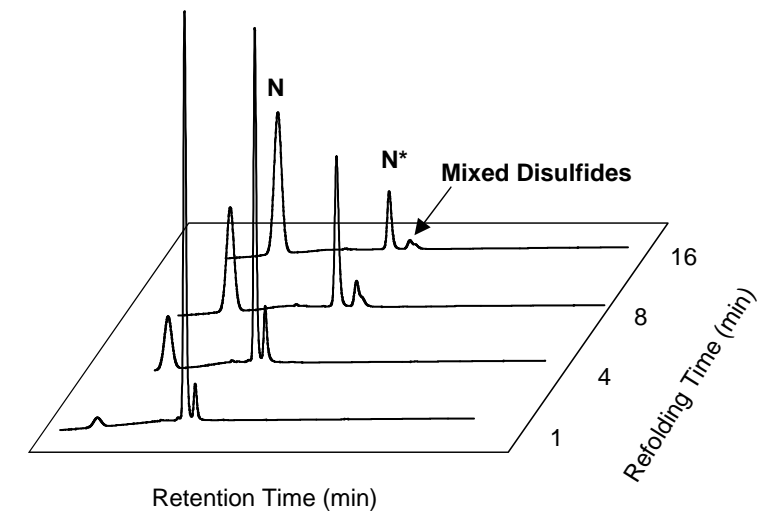

c)

Figure 18. HPLC chromatograms of a folding mixture of BPTI at different time intervals in the presence of (a) $10 \mathrm{mM} \mathrm{GSSG}$, (b) $0.25 \mathrm{mM}$ phosphonic acid disulfide (6), and (c) $0.25 \mathrm{mM}$ sulfonic acid disulfide $(\mathbf{8})$.

Creighton and Kim proposed folding models for BPTI which indicated that $\mathrm{N}^{*}$ does not undergo direct oxidation to native protein, but rearranges to $\mathrm{N}^{\prime}$ and then $\mathrm{N}^{\mathrm{SH}} \cdot{ }^{40,93,136} \mathrm{~N}^{\prime}$ and then $\mathrm{N}^{\mathrm{SH}}$ are subsequently oxidized to native protein. However, the above results shows that $\mathrm{N}^{*}$ does undergoes direct oxidation to $\mathrm{N}$. Furthermore, the results demonstrate that small molecule aromatic disulfides enhance the folding rate constants of $\mathrm{N}^{*}$ to $\mathrm{N}$ by $100-3000$ fold as compared to GSSG.

\subsubsection{Folding of lysozyme with aromatic monothiols (2 and 3 ) and their corresponding disulfides (6 and 7)}

All in vitro folding experiments with lysozyme were performed at $\mathrm{pH} 7.0$ or 8.0 and at a higher protein concentration $(1 \mathrm{mg} / \mathrm{mL})$ than traditionally used $(0.1 \mathrm{mg} / \mathrm{mL})$. In vitro folding was carried out using various concentrations of phosphonic acid monothiol (2) and its disulfide (6) or quaternary ammonium salt (3) and its disulfide (7) in comparison with $7 \mathrm{mM}$ GSH and $2 \mathrm{mM}$ GSSG by Dr. David Madar. At pH 7.0, aromatic thiol (2) and its disulfide (6) or aromatic thiol (3) and its disulfide (7) increased the 
folding rate up to 11 times and improved the yields between 20 and $40 \%$ as compared to GSH/GSSG. At pH 8.0, aromatic thiol (2) and its disulfide (6) or aromatic thiol (3) and its disulfide (7) increased the folding rate up to 7 times and improved the yields up to $25 \%$ as compared to GSH/GSSG (Figure 19 a-d).
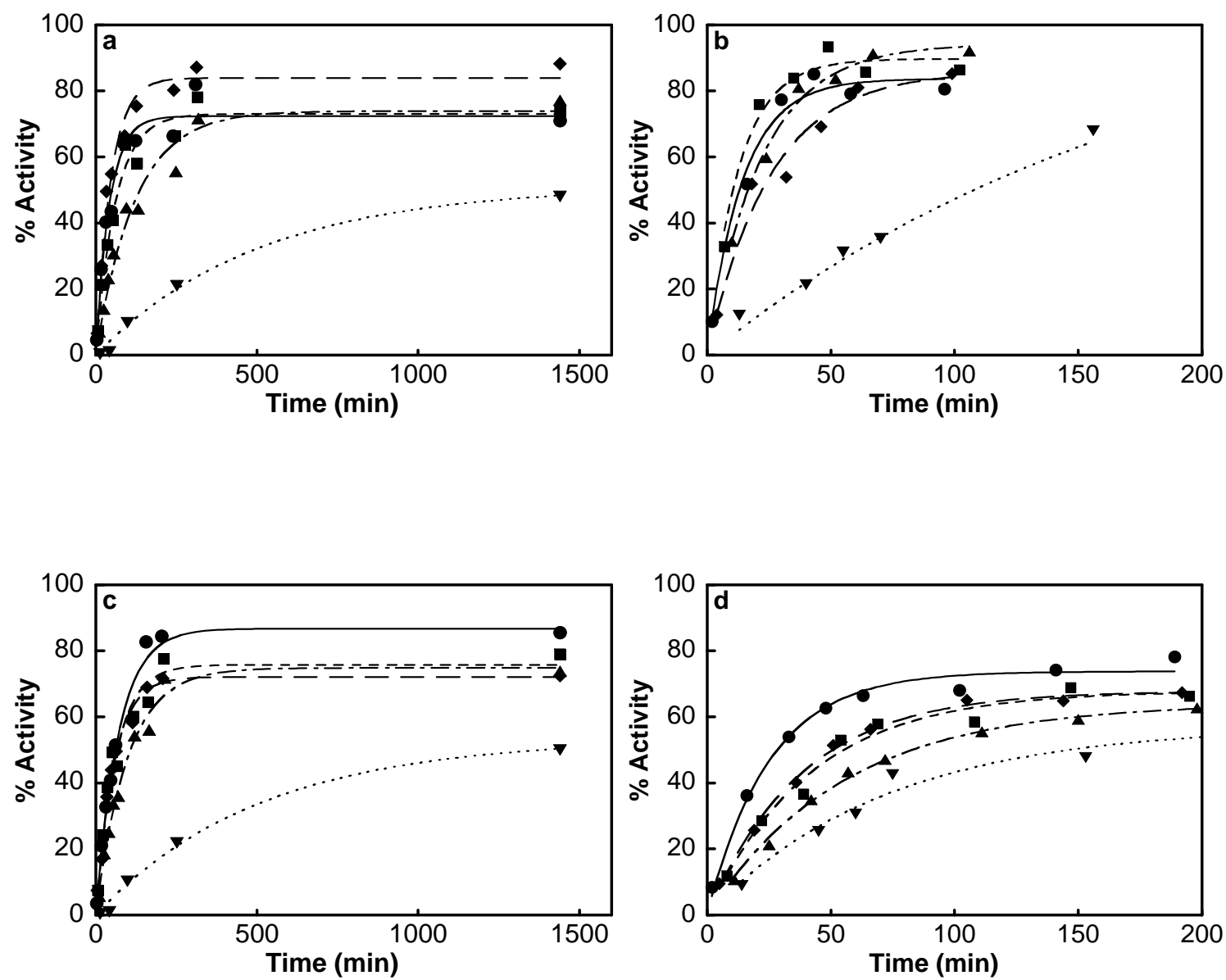

Figure 19. Folding of lysozyme at $1 \mathrm{mg} / \mathrm{mL}$ (a) At pH 7.0 with (४) $2 \mathrm{mM} \mathrm{2/1} \mathrm{mM} \mathrm{6,} \mathrm{(-)}$

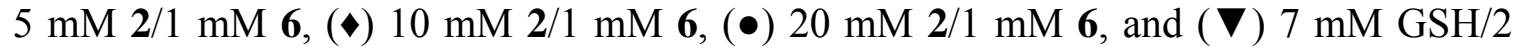
mM GSSG. (b) At pH 8.0 with (४) $10 \mathrm{mM} \mathrm{2/0.5} \mathrm{mM} \mathrm{6,} \mathrm{(-)} 20 \mathrm{mM} \mathrm{2/0.5} \mathrm{mM} \mathrm{6,} \mathrm{( \diamond )} 10$ $\mathrm{mM} \mathrm{2/1} \mathrm{mM} \mathrm{6,( \bullet )} 20 \mathrm{mM} \mathrm{2/1} \mathrm{mM} \mathrm{6,} \mathrm{and} \mathrm{( \nabla )} 7 \mathrm{mM} \mathrm{GSH} / 2 \mathrm{mM} \mathrm{GSSG}$. (c) At pH 7.0

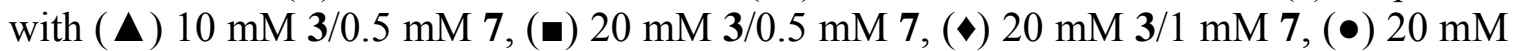

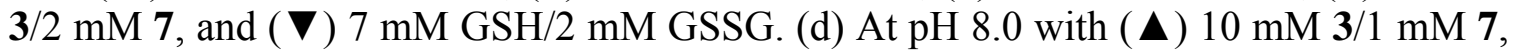
(•) $20 \mathrm{mM} \mathrm{3/1} \mathrm{mM} \mathrm{7,} \mathrm{( \bullet )} 20 \mathrm{mM} \mathrm{3/2} \mathrm{mM} \mathrm{7,} \mathrm{( \bullet )} 50 \mathrm{mM} \mathrm{3/2} \mathrm{mM} \mathrm{7,} \mathrm{and} \mathrm{( \nabla )} 7 \mathrm{mM}$ GSH/2 mM GSSG. 


\subsection{Synthesis of aromatic dithiols (9-15)}

The aim of the project was to increase the in vitro folding rates and yields of disulfide containing proteins by combining the advantageous properties of aliphatic dithiols and aromatic monothiols. Raines et al. have demonstrated that aliphatic dithiols increase the in vitro folding yield of RNase A relative to aliphatic monothiols, while Lees et al. have shown that aromatic monothiols increase in vitro folding rates of RNase A and lysozyme relative to aliphatic monothiols. ${ }^{4,32,35,38,117}$ Thus, I planned to synthesize dithiols containing an aromatic thiol group. The compounds were designed to mimic PDI, such that one thiol group is more reactive than the other. Hence, the more reactive thiol group was present on an aromatic ring and the other less reactive thiol group was on an aliphatic chain. Additionally, the compounds should be aqueous soluble from $\mathrm{pH} 6.0$ to 8.0 , the $\mathrm{pH}$ range used to fold most proteins in vitro. Therefore, polyethylene groups were inserted into the aliphatic chain to improve solubility. Furthermore, ortho- and para-substituted aromatic ethylene glycol dithiols were selected to provide a wide range of thiol $\mathrm{pK}_{\mathrm{a}}$ values (5-7). The ortho- and para- substituted aromatic ethylene glycol dithiols consisted of one thiol group on the aromatic ring and a second thiol group on the free end of a polyethylene glycol chain. The aliphatic chain of polyethylene glycol was connected to the aromatic ring via an esterification reaction.

\subsubsection{Synthesis of ortho- and para-substituted aromatic ethylene glycol dithiols (9-} 15)

To synthesizes ortho- and para- series of aromatic ethylene glycol dithiols (9-15), ethylene glycol disulfides (37, 38, and 45) were synthesizes first. Ethylene glycol 
disulfides (37, 38, and 45) were prepared as shown below. These ethylene glycol disulfides $(\mathbf{3 7}, \mathbf{3 8}$, and 45) were then treated with acid chloride (49) to prepare orthosubstituted aromatic ethylene glycol dithiols or acid chloride (55) to prepare parasubstituted aromatic ethylene glycol dithiols.

4.2.1.1 Synthesis of di-, tri-, tetra- and hexaethylene glycol disulfides $(37,38,45$, and 46)

Treatment of di- and triethylene glycol chlorides (33) and (34) with thiourea (32) followed by hydrolysis with $\mathrm{NaOH}$ gave di- and triethylene glycol thiols (35) and (36), respectively. Thiols (35) and (36) were then subjected to air oxidation for 1 week to give the corresponding disulfides (37) and (38), respectively, (Scheme 7). Tetra- and hexaethylene glycol disulfides, (45) and (46), were prepared by treating tetra- and hexaethylene glycol, (39) and (40), respectively, with p-toluenesulfonyl chloride to form

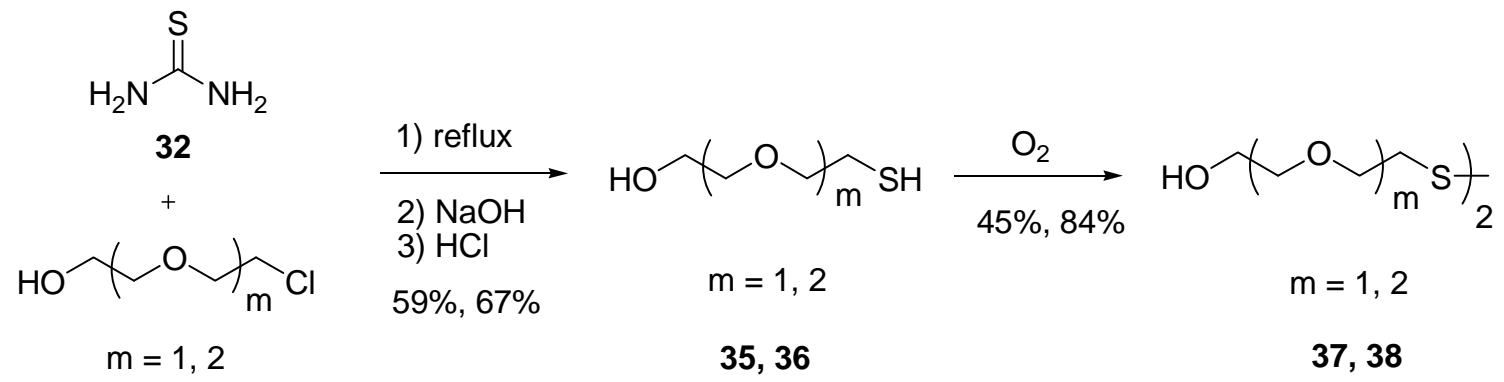

33,34

Scheme 7. Synthesis of di- and triethylene glycol disulfides (37 and 38)

their respective monotosylates (41) and (42). The monotosylates (41) and (42) were then treated with thiourea to form the tetra- and hexaethylene glycol thiols (43) and (44), respectively. The tera- and hexaethylene glycol thiols, (43) and (44), were then subjected 
to air oxidation by stirring vigorously in water for 1 week to form the corresponding disulfides (45) and (46), respectively (Scheme 8).<smiles>CCN(C)C(C)(C)OCC(C)(C)OCC(C)(C)O</smiles>

$\mathrm{m}=3,5$

39,40

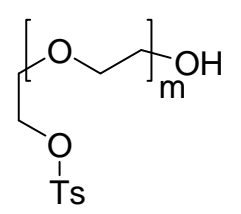

$\mathrm{m}=3,5$
1. Thiourea $\mathrm{EtOH}, 24 \mathrm{~h}$

2. $\mathrm{NaOH} / \mathrm{EtOH}$

$\mathrm{H}_{2} \mathrm{O}, 2.5 \mathrm{~h}$

$89 \%, 58 \%$

41, 42<smiles>CC(CS)OCC(C)(O)C(C)(C)OCC(C)OCC(C)(O)c1ccccc1</smiles>

$m=3,5$

$m=3,5$

43, 44

45,46

Scheme 8. Synthesis of tetra- and hexaethylene glycol disulfides (45 and 46)

\subsubsection{Synthesis of ortho-substituted aromatic mono-, di-, tri-, and tetraethylene}

\section{glycol dithiols (9-12)}<smiles>O=C(O)c1ccccc1S</smiles>

47<smiles>CC(C)SCOCCOC(=O)c1ccccc1S</smiles>

$\mathrm{m}=0,1,2,3$

$51,52,53,54$

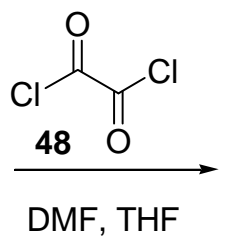

DMF, THF

49

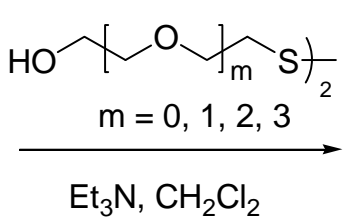

$50,37,38,45$

$$
m=0,1,2,3
$$

$9,10,11,12$

Scheme 9. Synthesis of ortho-substituted aromatic mono-, di-, tri-, and tetraethylene glycol dithiols (9-12) 
The first step in the synthesis of ortho-substituted aromatic mono-, di-, tri-, and tetraethylene glycol dithiols (9-12) involved the treatment of readily available dithiosalicylic acid (47) with oxalyl chloride (48) and DMF in THF to produce an acid chloride (49). In the same pot, the acid chloride (49) was then treated with mono-, di-, triand tetraethylene glycol disulfides $(\mathbf{5 0}, \mathbf{3 7}, \mathbf{3 8}$, and $\mathbf{4 5})$ to form their respective polymer (51-54). The polymers (51-54) was then reduced with DTT in the presence of a base, $\mathrm{Et}_{3} \mathrm{~N}$, to give ortho-substituted aromatic mono-, di-, tri- and tetra ethylene glycol dithiols (9-12), respectively, (Scheme 9).

\subsubsection{Synthesis of para-substituted aromatic di-, tri-, and tetraethylene glycol dithiols (13-15)}<smiles>CC(C)(C)Sc1ccc(C(=O)O)cc1</smiles><smiles>O=C(Cl)C(=O)Cl</smiles>

5<smiles>CC(C)(C)Sc1ccc(C(=O)Cl)cc1</smiles>

55

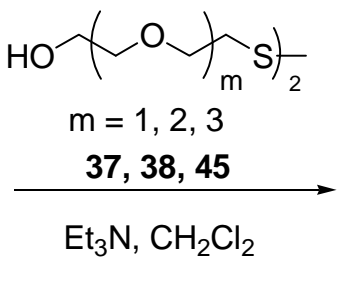

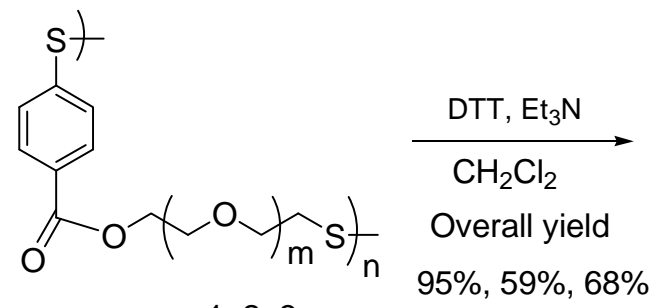

$\mathrm{m}=1,2,3$

$56,57,58$

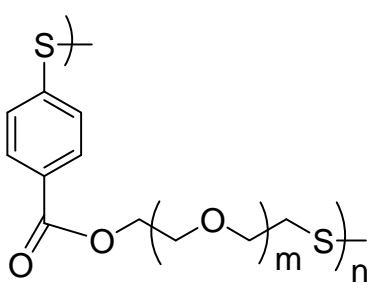

$\mathrm{m}=1,2,3$

$56,57,58$

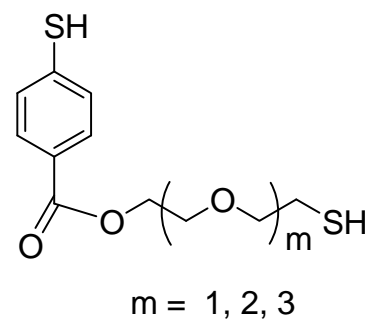

13, 14, 15

Scheme 10. Synthesis of para-substituted aromatic di-, tri-, and tetraethylene glycol dithiols (13-15) 
The para-substituted aromatic di-, tri-, and tetraethylene glycol dithiols (13-15) were synthesized in the same manner as the ortho-substituted aromatic ethylene glycol dithiols (Scheme 10). The only difference between the synthesis of the ortho- and paraseries of compounds was that the disulfide of 4-mercaptobenzoic acid (5) was used instead of dithiosalicylic acid (47).

ortho- and para- Substituted aromatic dithiols $(\mathbf{1 1}, \mathbf{1 2}, \mathbf{1 4}$, and 15) were then examined for their ability to fold reduced lysozyme. Lysozyme was selected as this enzyme has been extensively studied, and its folding pathway has been well characterized. . $^{37,85,129,137-139}$ The folding of reduced lysozyme was carried out in the presence of various concentrations of aromatic dithiols (11, 12, 14, and 15) in combination with either $0.2 \mathrm{mM}$ GSSG or $2 \mathrm{mM} \mathrm{GSSG}$. These concentrations of GSSG were selected as our previous results obtained with RNase A and lysozyme used $0.2 \mathrm{mM}$ or $2 \mathrm{mM} \mathrm{GSSG} .{ }^{4,35-37}$ These folding experiments were then compared directly with $7 \mathrm{mM}$ GSH and 2 mM GSSG. These concentrations of GSH and GSSG were selected for the folding experiments as they gave the best combination of folding rate and yield in our previous study at $0.1 \mathrm{mg} / \mathrm{mL}$ lysozyme concntration. ${ }^{37}$ All the folding experiments were carried out at $\mathrm{pH} 7.0$ and 8.0 , and $0.1 \mathrm{mg} / \mathrm{mL}(7 \mu \mathrm{M})$ lysozyme concentration at $25^{\circ} \mathrm{C}$.

The folding of lysozyme was followed using the recovery of enzymatic activity. Reduced lysozyme $(10 \mathrm{mg} / \mathrm{mL})$, from which the dithioerythritol (DTE) had been removed by gel permeation chromatography, was diluted 100 -fold into renaturation buffer containing $0.1 \mathrm{M}$ buffer (bis tris propane- $\mathrm{HCl}$ for $\mathrm{pH} 7.0$ or Tris- $\mathrm{HCl}$ for $\mathrm{pH} 8.0$ ), $1 \mathrm{mM}$ EDTA, $0.5 \mathrm{M}$ guanidine hydrochloride (Gdn $\mathrm{HCl}$ ), and redox buffer. ${ }^{131,140}$ The use of EDTA was to prevent metal catalyzed air oxidation of thiols. ${ }^{129}$ To minimize protein 
aggregation during folding, $\mathrm{Gdn} \mathrm{HCl}$ was added..$^{27,131}$ At specific times, aliquots were removed from the folding reaction and the enzymatic activity was determined by adding the aliquots to a suspension of M. lysodeikticus. ${ }^{129,131,132}$ The decrease in light scattering was monitored at $450 \mathrm{~nm}$ for $2 \mathrm{~min}$. The change in light scattering per minute is proportional to enzymatic activity.

\subsubsection{Folding of lysozyme with ortho-substituted aromatic ethylene glycol dithiols} (11 and 12)

Initially a range of concentrations was examined to find the best concentrations of dithiols (11 and 12) for the folding of lysozyme. At $20 \mathrm{mM}$, ortho-substituted aromatic ethylene glycol dithiols (11 and $\mathbf{1 2}$ ) were only partially soluble in $0.1 \mathrm{M}$ bis tris propane$\mathrm{HCl}$ buffer ( $\mathrm{pH}$ 7.0) and $0.1 \mathrm{M}$ Tris-HCl buffer ( $\mathrm{pH}$ 8.0). The solubility of dithiols (11 and 12) was determined by Ellman's method. ${ }^{141}$ The solubility of ortho-substituted aromatic tri- and tetraethylene glycol dithiols (11 and 12) was found to be 4 and $10 \mathrm{mM}$ at $\mathrm{pH} 7.0$, respectively, and 10 and $20 \mathrm{mM}$ at $\mathrm{pH} 8.0$, respectively. Thus, the concentrations of triethylene glycol dithiol (11) examined were in the range of 0.25 to 2 $\mathrm{mM}$ at $\mathrm{pH} 7.0$ and 0.25 to $10 \mathrm{mM}$ at $\mathrm{pH} 8.0$, whereas that of tetraethylene glycol dithiol (12) were in the range of 0.25 to $10 \mathrm{mM}$ at both $\mathrm{pH} 7.0$ and 8.0. The folding experiments were then performed with tri- and tetraethylene glycol dithiols (11 and 12) in combination with either 0.2 or $2 \mathrm{mM}$ GSSG at $\mathrm{pH} 7.0$ and $\mathrm{pH} 8.0$ (Tables 1 and 2, Figures 20-23). 

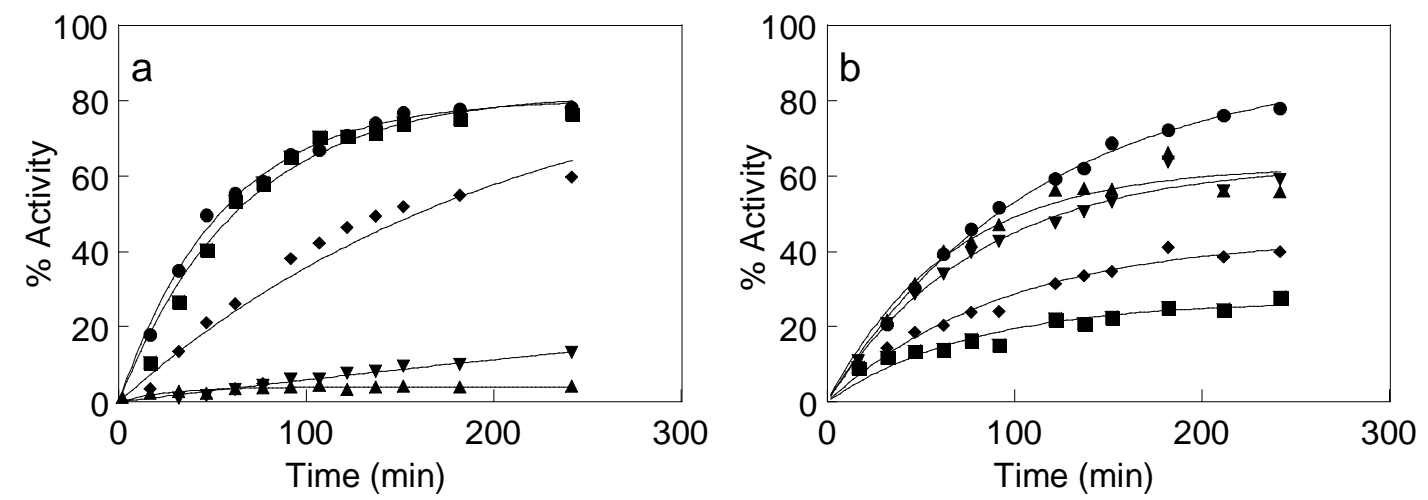

Figure 20. Folding of lysozyme $(0.1 \mathrm{mg} / \mathrm{mL})$ at $\mathrm{pH} 7.0$ : (a) under standard conditions or $0.2 \mathrm{mM}$ GSSG and various concentrations of ortho-substituted aromatic triethylene glycol dithiol (11); (b) under standard conditions or $2 \mathrm{mM}$ GSSG and various concentrations of ortho-substituted aromatic triethylene glycol dithiol (11).(a) (•) $7 \mathrm{mM}$ GSH/2 mM GSSG (standard conditions), (•) $0.25 \mathrm{mM} \mathrm{11/0.2} \mathrm{mM} \mathrm{GSSG,} \mathrm{( \diamond )} 0.50 \mathrm{mM}$ 11/0.2 mM GSSG, ( $\boldsymbol{\nabla}) 1.0 \mathrm{mM} \mathrm{11/0.2} \mathrm{mM} \mathrm{GSSG}$, and ( $\boldsymbol{\Delta}$ ) 2.0 mM 11/0.2 mM GSSG; (b) (•) $7 \mathrm{mM} \mathrm{GSH} / 2 \mathrm{mM} \mathrm{GSSG}$ (standard conditions), (•) $0.25 \mathrm{mM} \mathrm{11/2} \mathrm{mM} \mathrm{GSSG}$, (•)

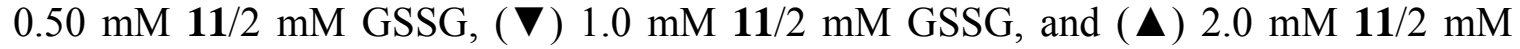
GSSG.
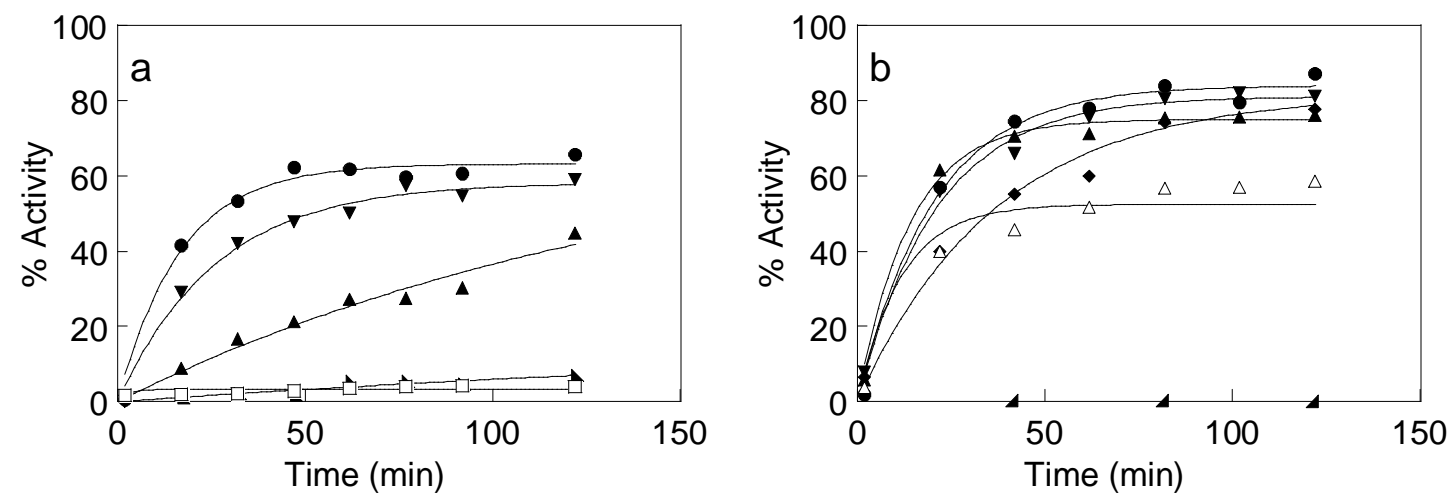

Figure 21. Folding of lysozyme $(0.1 \mathrm{mg} / \mathrm{mL})$ at $\mathrm{pH}$ 8.0: (a) under standard conditions or $0.2 \mathrm{mM}$ GSSG and various concentrations of ortho-substituted aromatic triethylene glycol dithiol (11); (b) under standard conditions or $2 \mathrm{mM}$ GSSG and various concentrations of ortho-substituted aromatic triethylene glycol dithiol (11). (a) (•) $7 \mathrm{mM}$

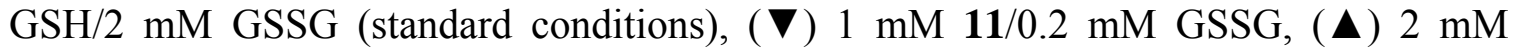

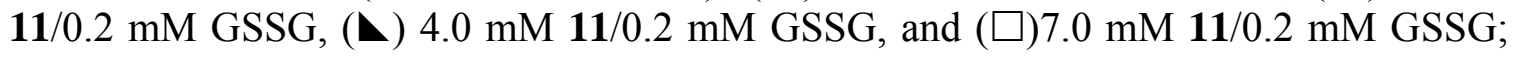
(b) (•) $7 \mathrm{mM} \mathrm{GSH} / 2 \mathrm{mM} \mathrm{GSSG}$ (standard conditions), (•) $0.5 \mathrm{mM} \mathrm{11/2} \mathrm{mM} \mathrm{GSSG},(\boldsymbol{\nabla})$

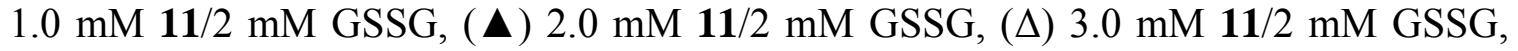
and (厶) $10.0 \mathrm{mM} \mathrm{11/2} \mathrm{mM} \mathrm{GSSG.}$ 

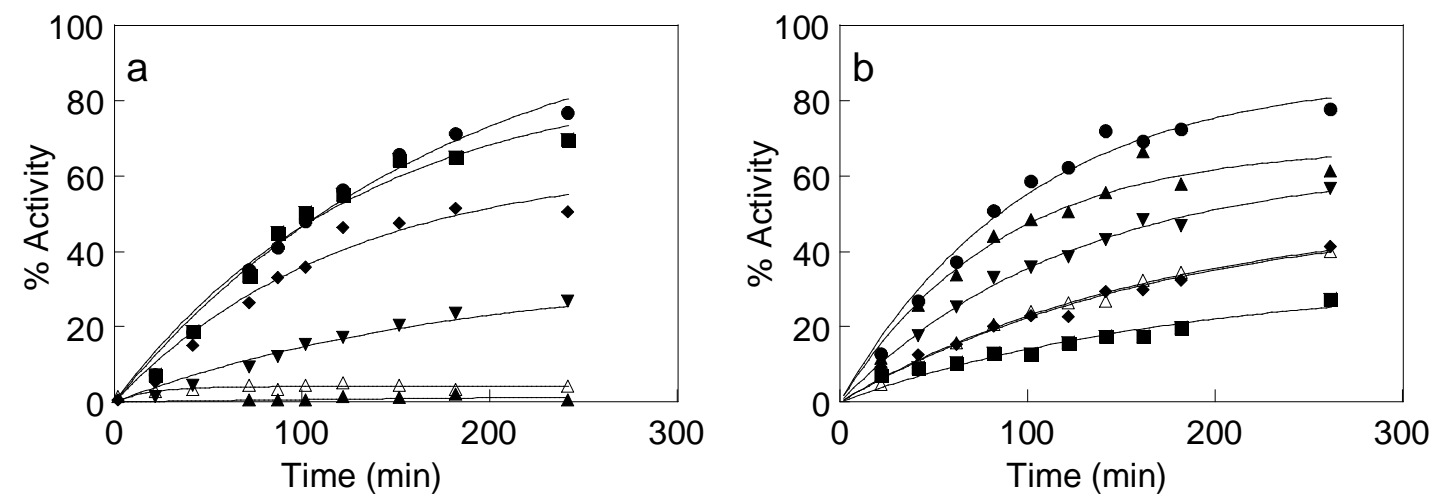

Figure 22. Folding of lysozyme $(0.1 \mathrm{mg} / \mathrm{mL})$ at $\mathrm{pH} 7.0$ : (a) under standard conditions or $0.2 \mathrm{mM} \mathrm{GSSG}$ and various concentrations of ortho-substituted aromatic tetraethylene glycol dithiol (12); (b) under standard conditions or $2 \mathrm{mM}$ GSSG and various concentrations of ortho-substituted aromatic tetraethylene glycol dithiol (12). (a) (•) 7

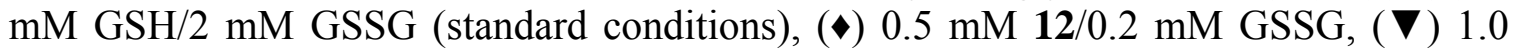

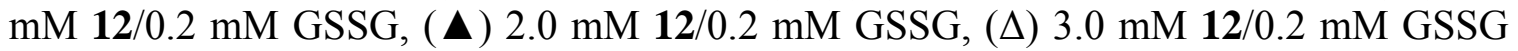

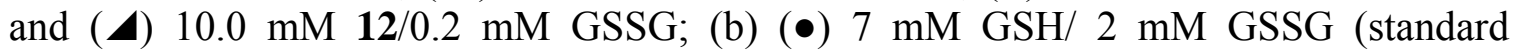

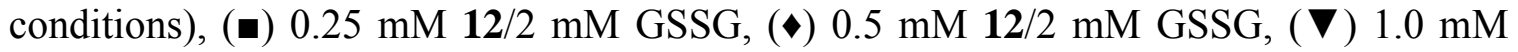

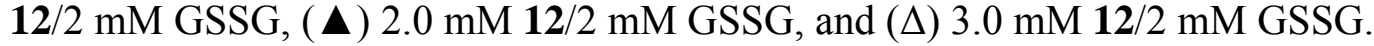
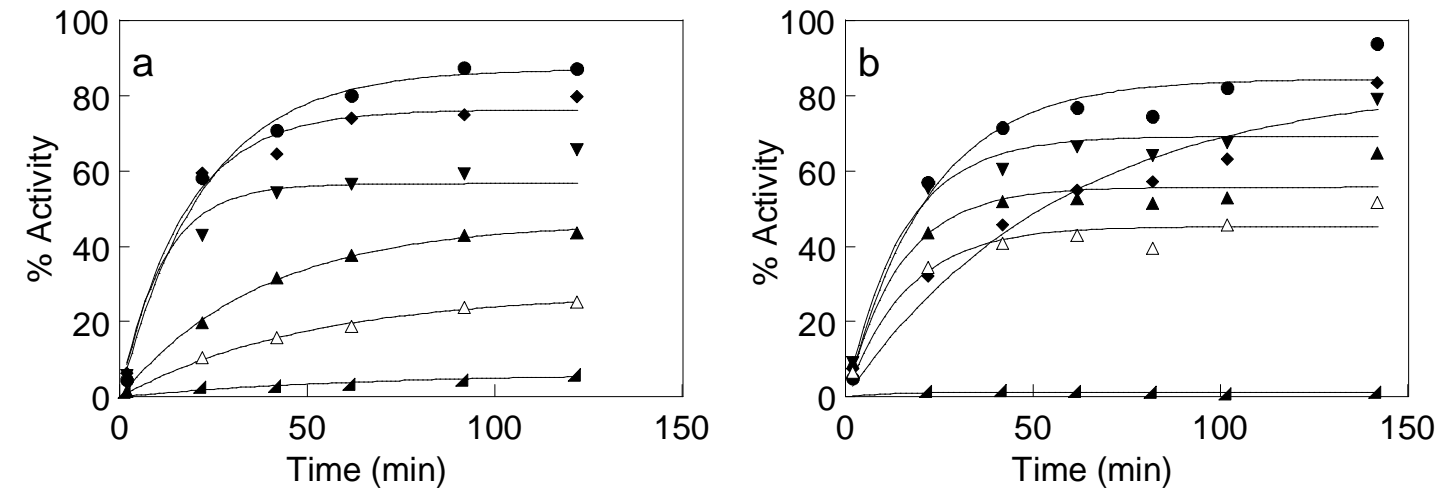

Figure 23. Folding of lysozyme $(0.1 \mathrm{mg} / \mathrm{mL})$ at $\mathrm{pH}$ 8.0: (a) under standard conditions or $0.2 \mathrm{mM}$ GSSG and various concentrations of ortho-substituted aromatic tetraethylene glycol dithiol (12); (b) under standard conditions or $2 \mathrm{mM}$ GSSG and various concentrations of ortho-substituted aromatic tetraethylene glycol dithiol (12). (a) (•) 7

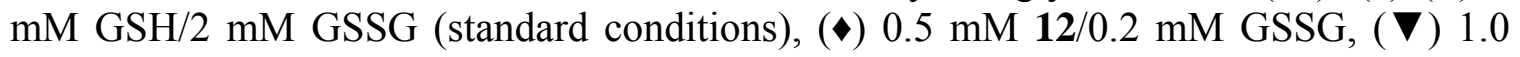

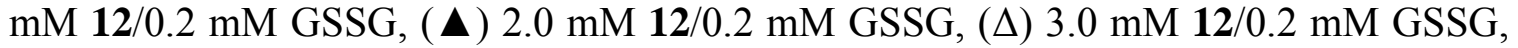

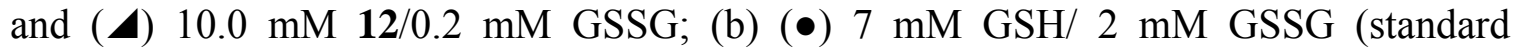

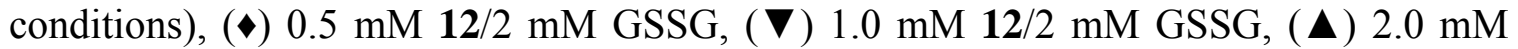

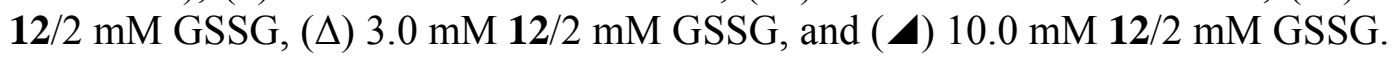


Table 1. Folding of lysozyme with ortho-substituted aromatic triethylene glycol dithiol (11) at pH 7.0 and 8.0

\begin{tabular}{|c|c|c|c|}
\hline \multicolumn{4}{|c|}{ pH 7.0} \\
\hline Redox buffer & $A(\%)$ & $k\left(\min ^{-1}\right)$ & $A^{*} k(\% / \mathrm{min})$ \\
\hline $0.25 \mathrm{mM} \mathrm{11} / 0.2 \mathrm{mM} \mathrm{GSSG}$ & 66 & 0.013 & 0.9 \\
\hline $0.5 \mathrm{mM} \mathrm{11} / 0.2 \mathrm{mM}$ GSSG & 55 & 0.002 & 0.1 \\
\hline $1 \mathrm{mM} \mathrm{11/0.2} \mathrm{mM} \mathrm{GSSG}$ & 20 & 0.004 & 0.1 \\
\hline $2 \mathrm{mM} \mathrm{11} / 0.2 \mathrm{mM}$ GSSG & 19 & 0.001 & 0.0 \\
\hline $0.25 \mathrm{mM} \mathrm{11} / 2 \mathrm{mM}$ GSSG & 26 & 0.015 & 0.4 \\
\hline $0.5 \mathrm{mM} \mathrm{11} / 2 \mathrm{mM}$ GSSG & 43 & 0.012 & 0.5 \\
\hline $1 \mathrm{mM} \mathrm{11/2} \mathrm{mM} \mathrm{GSSG}$ & 63 & 0.013 & 0.8 \\
\hline $2 \mathrm{mM} \mathrm{11/2} \mathrm{mM} \mathrm{GSSG}$ & 62 & 0.016 & 0.9 \\
\hline $7 \mathrm{mM} \mathrm{GSH} / 2 \mathrm{mM} \mathrm{GSSG}$ & 82 & 0.010 & 0.8 \\
\hline \multicolumn{4}{|c|}{ pH 8.0} \\
\hline Redox buffer & $A(\%)$ & $k\left(\min ^{-1}\right)$ & $A^{*} k(\% / \mathrm{min})$ \\
\hline $1 \mathrm{mM} \mathrm{11} / 0.2 \mathrm{mM}$ GSSG & 58 & 0.04 & 2.3 \\
\hline $2 \mathrm{mM} \mathrm{11} / 0.2 \mathrm{mM}$ GSSG & 62 & 0.009 & 0.6 \\
\hline $4 \mathrm{mM} \mathrm{11} / 0.2 \mathrm{mM}$ GSSG & 9 & 0.014 & 0.1 \\
\hline $7 \mathrm{mM} \mathrm{11} / 0.2 \mathrm{mM}$ GSSG & 0 & 0.159 & 0.2 \\
\hline $0.5 \mathrm{mM} \mathrm{11} / 2 \mathrm{mM}$ GSSG & 83 & 0.026 & 2.2 \\
\hline $1 \mathrm{mM} \mathrm{11} / 2 \mathrm{mM}$ GSSG & 81 & 0.049 & 4.0 \\
\hline $2 \mathrm{mM}$ 11/2 mM GSSG & 75 & 0.073 & 5.5 \\
\hline $3 \mathrm{mM} \mathrm{11} / 2 \mathrm{mM}$ GSSG & 57 & 0.049 & 2.8 \\
\hline $10 \mathrm{mM} \mathrm{11} / 2 \mathrm{mM} \mathrm{GSSG}$ & 0 & 0.107 & 0.0 \\
\hline $7 \mathrm{mM} \mathrm{GSH} / 2 \mathrm{mM}$ GSSG & 84 & 0.050 & 4.2 \\
\hline
\end{tabular}

The folding of lysozyme in the presence of aromatic dithiols (11 and 12) was compared by fitting the data to a single exponential function. The exponential function used was $y=A\left(1-\mathrm{e}^{-k t}\right)$, where $A$ is the maximal enzymatic activity achieved, $k$ is the apparent folding rate constant, and $t$ is time. The initial folding rate corresponds to $A^{*} k$. 
The $A, k$, and $A^{*} k$ values for ortho-substituted aromatic tri- and tetraethylene glycol dithiols (11 and 12) are shown in Tables 1 and 2.

Table 2. Folding of lysozyme with ortho-substituted aromatic tetraethylene glycol dithiol (12) at $\mathrm{pH} 7.0$ and 8.0

\begin{tabular}{|c|c|c|c|}
\hline \multicolumn{4}{|c|}{ pH 7.0} \\
\hline Redox buffer & $A(\%)$ & $k\left(\min ^{-1}\right)$ & $A^{*} k(\% / \mathrm{min})$ \\
\hline $0.5 \mathrm{mM} \mathrm{12} / 0.2 \mathrm{mM}$ GSSG & 85 & 0.008 & 0.7 \\
\hline $1 \mathrm{mM} \mathrm{12} / 0.2 \mathrm{mM}$ GSSG & 62 & 0.009 & 0.5 \\
\hline $2 \mathrm{mM} \mathrm{12} / 0.2 \mathrm{mM} \mathrm{GSSG}$ & 30 & 0.007 & 0.2 \\
\hline $3 \mathrm{mM} \mathrm{12} / 0.2 \mathrm{mM}$ GSSG & 2 & 0.010 & 0.02 \\
\hline $10 \mathrm{mM}$ 12/0.2 mM GSSG & 0 & 0.190 & 0.3 \\
\hline $0.25 \mathrm{mM} \mathrm{12} / 2 \mathrm{mM}$ GSSG & 45 & 0.004 & 0.2 \\
\hline $0.5 \mathrm{mM} \mathrm{12} / 2 \mathrm{mM} \mathrm{GSSG}$ & 60 & 0.005 & 0.3 \\
\hline $1 \mathrm{mM} \mathrm{12/2} \mathrm{mM}$ GSSG & 69 & 0.007 & 0.5 \\
\hline $2 \mathrm{mM} \mathrm{12/2} \mathrm{mM} \mathrm{GSSG}$ & 69 & 0.012 & 0.8 \\
\hline $3 \mathrm{mM} \mathrm{12} / 2 \mathrm{mM}$ GSSG & 84 & 0.01 & 0.8 \\
\hline $7 \mathrm{mM} \mathrm{GSH} / 2 \mathrm{mM}$ GSSG & 87 & 0.010 & 0.9 \\
\hline \multicolumn{4}{|c|}{ pH 8.0} \\
\hline Redox buffer & $A(\%)$ & $k\left(\min ^{-1}\right)$ & $A^{*} k(\% / \mathrm{min})$ \\
\hline $0.5 \mathrm{mM} \mathrm{12} / 0.2 \mathrm{mM}$ GSSG & 76 & 0.061 & 4.7 \\
\hline $1 \mathrm{mM} \mathrm{12/0.2} \mathrm{mM} \mathrm{GSSG}$ & 62 & 0.052 & 3.2 \\
\hline $2 \mathrm{mM} \mathrm{12} / 0.2 \mathrm{mM}$ GSSG & 45 & 0.028 & 1.3 \\
\hline $3 \mathrm{mM} \mathrm{12} / 0.2 \mathrm{mM}$ GSSG & 27 & 0.023 & 0.6 \\
\hline $10 \mathrm{mM} \mathrm{12} / 0.2 \mathrm{mM}$ GSSG & 0 & 0.322 & 0.5 \\
\hline $0.5 \mathrm{mM} \mathrm{12/2} \mathrm{mM}$ GSSG & 81 & 0.018 & 1.5 \\
\hline $1 \mathrm{mM} \mathrm{12/2} \mathrm{mM} \mathrm{GSSG}$ & 69 & 0.068 & 4.7 \\
\hline $2 \mathrm{mM} \mathrm{12/2} \mathrm{mM} \mathrm{GSSG}$ & 55 & 0.072 & 4.0 \\
\hline $3 \mathrm{mM} 12 / 2 \mathrm{mM}$ GSSG & 45 & 0.065 & 3.0 \\
\hline $10 \mathrm{mM} \mathrm{12} / 2 \mathrm{mM}$ GSSG & 1 & 0.299 & 0.4 \\
\hline $7 \mathrm{mM} \mathrm{GSH} / 2 \mathrm{mM} \mathrm{GSSG}$ & 87 & 0.047 & 4.0 \\
\hline
\end{tabular}




\subsubsection{Folding of lysozyme with para -series of aromatic ethylene glycol dithiols}

\section{(14 and 15)}

Folding experiments with lysozyme using para-substituted aromatic tri- and tetraethylene glycol dithiols (14 and 15) were also performed. In a similar manner as ortho-substituted aromatic tri- and tetraethylene glycol dithiols (11and 12), a range of concentrations was examined to find the best concentrations of dithiols 14 and 15. Unlike dithiols 11 and 12, dithiols 14 and 15 were soluble ( $>20 \mathrm{mM}$ ) in $0.1 \mathrm{M}$ bis tris propane$\mathrm{HCl}$ buffer $(\mathrm{pH} 7.0)$ and $0.1 \mathrm{M}$ Tris- $\mathrm{HCl}$ buffer $(\mathrm{pH}$ 8.0). The concentrations of dithiols 14 and 15 examined were in the range of 0.5 to $10 \mathrm{mM}$ at $\mathrm{pH} 7.0$ and 8.0. Although dithiols 14 and 15 were soluble in $0.1 \mathrm{M}$ bis tris propane- $\mathrm{HCl}$ buffer $(\mathrm{pH} 7.0)$ and $0.1 \mathrm{M}$ Tris-HCl buffer ( $\mathrm{pH} 8.0$ ), concentrations above $10 \mathrm{mM}$ were not used for folding studies as the protein showed little or no activity at $10 \mathrm{mM}$. Folding experiments were carried out using various concentrations of dithiols $\mathbf{1 4}$ and $\mathbf{1 5}$ in combination with either 0.2 or 2 mM GSSG at pH 7.0 and 8.0. (Tables 3 and 4, Figures 24-27). These folding experiments were then done simultaneously with the standard conditions, $7 \mathrm{mM} \mathrm{GSH}$ and $2 \mathrm{mM}$ GSSG. The folding of lysozyme in the presence of dithiols $\mathbf{1 4}$ and $\mathbf{1 5}$ was then compared by fitting the data to a single exponential function, $y=A\left(1-\mathrm{e}^{-k t}\right)$. The $A, k$, and $A^{* k}$ values for dithiols $\mathbf{1 4}$ and $\mathbf{1 5}$ are shown in the tables 3 and 4. 

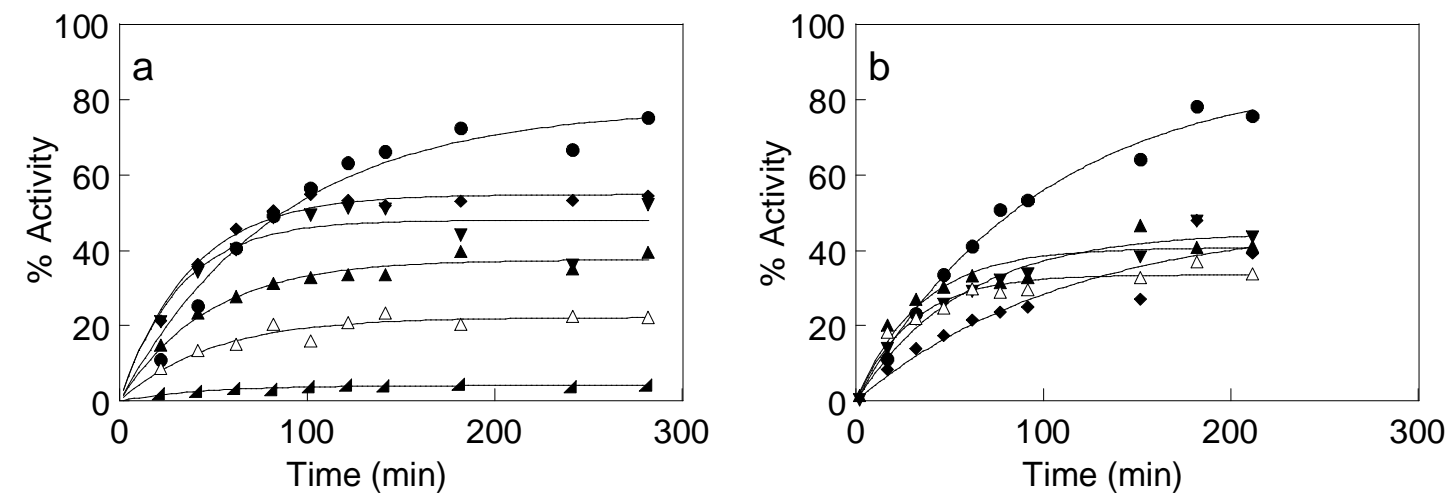

Figure 24. Folding of lysozyme $(0.1 \mathrm{mg} / \mathrm{mL})$ at $\mathrm{pH} 7.0$ : (a) under standard conditions or $0.2 \mathrm{mM} \mathrm{GSSG}$ and various concentrations of para-substituted aromatic triethylene glycol dithiol (14); (b) under standard conditions or $2 \mathrm{mM} \mathrm{GSSG}$ and various concentrations of para-substituted aromatic triethylene glycol dithiol (14). (a) (•) $7 \mathrm{mM} \mathrm{GSH} / 2 \mathrm{mM} \mathrm{GSSG}$

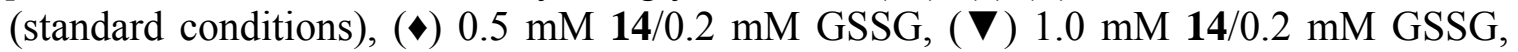

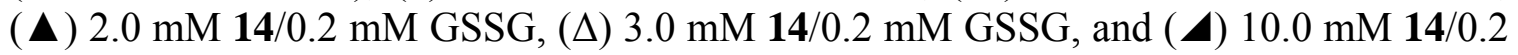
mM GSSG; (b) (•) $7 \mathrm{mM}$ GSH/ $2 \mathrm{mM} \mathrm{GSSG}$ (standard conditions), (•) $0.5 \mathrm{mM} \mathrm{14/2}$

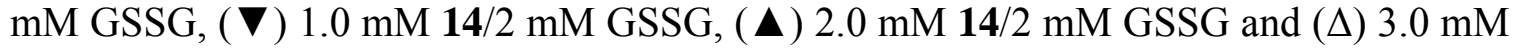
14/2 mM GSSG.
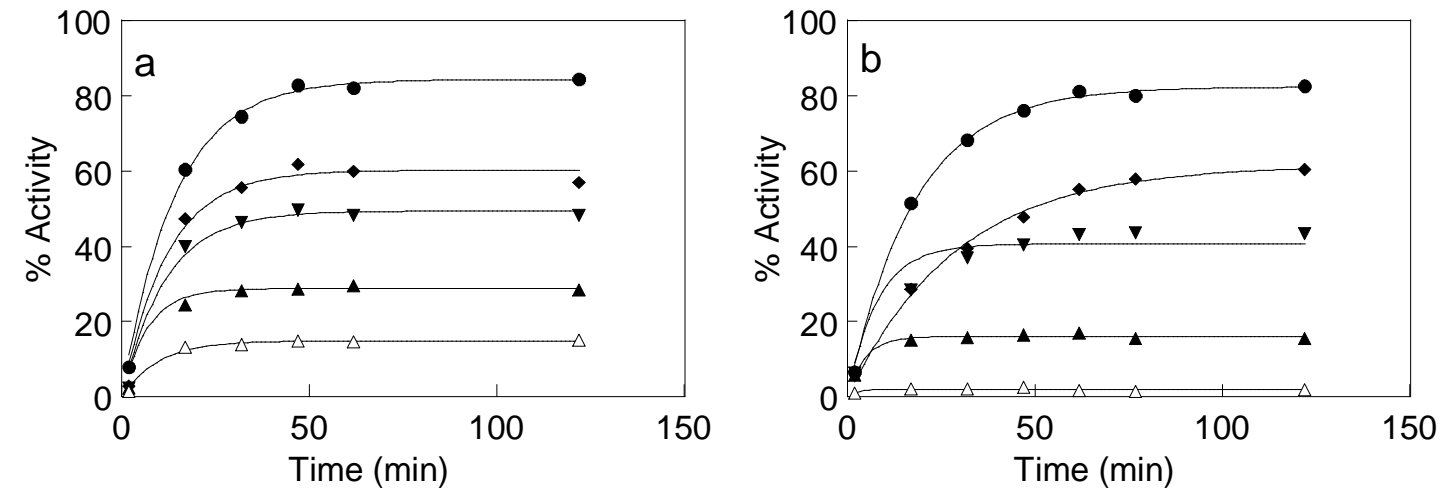

Figure 25. Folding of lysozyme $(0.1 \mathrm{mg} / \mathrm{mL})$ at $\mathrm{pH}$ 8.0: (a) under standard conditions or $0.2 \mathrm{mM} \mathrm{GSSG}$ and various concentrations of para-substituted aromatic triethylene glycol dithiol (14); (b) under standard conditions or $2 \mathrm{mM} \mathrm{GSSG}$ and various concentrations of para-substituted aromatic triethylene glycol dithiol (14). (a) (•) $7 \mathrm{mM} \mathrm{GSH} / 2 \mathrm{mM} \mathrm{GSSG}$

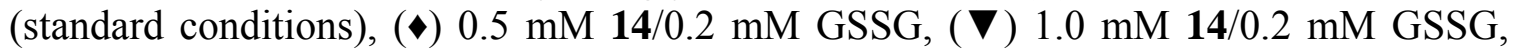

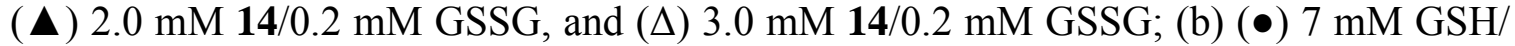

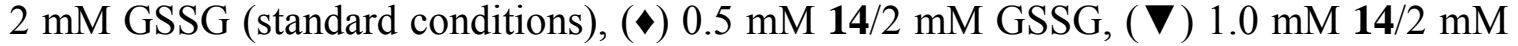
GSSG, ( $\mathbf{\Delta}) 2.0 \mathrm{mM} \mathrm{14/2} \mathrm{mM} \mathrm{GSSG}$ and $(\Delta) 3.0 \mathrm{mM} \mathrm{14/2} \mathrm{mM}$ GSSG. 

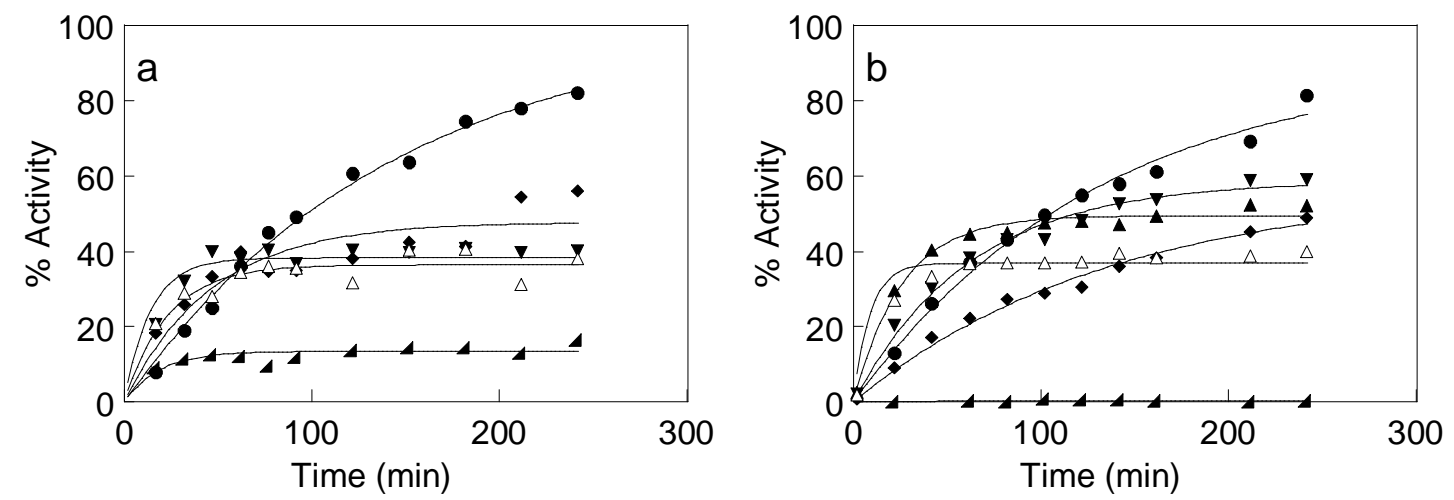

Figure 26. Folding of lysozyme $(0.1 \mathrm{mg} / \mathrm{mL})$ at $\mathrm{pH} 7.0$ : (a) under standard conditions or $0.2 \mathrm{mM}$ GSSG and various concentrations of para-substituted aromatic tetraethylene glycol dithiol (15); (b) under standard conditions or $2 \mathrm{mM}$ GSSG and various concentrations of para-substituted aromatic tetraethylene glycol dithiol (15). (a) (•) 7

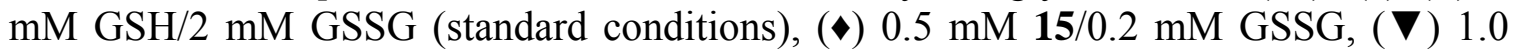

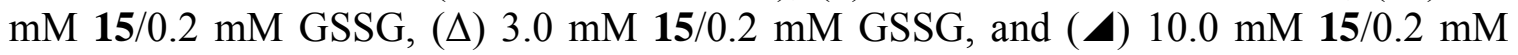

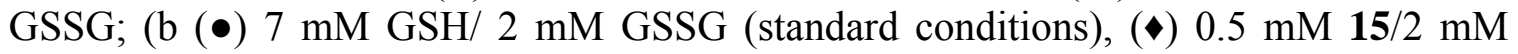

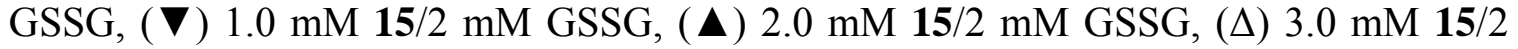
mM GSSG, and ( $\boldsymbol{A}) 10.0 \mathrm{mM} \mathrm{15/2} \mathrm{mM} \mathrm{GSSG}$.
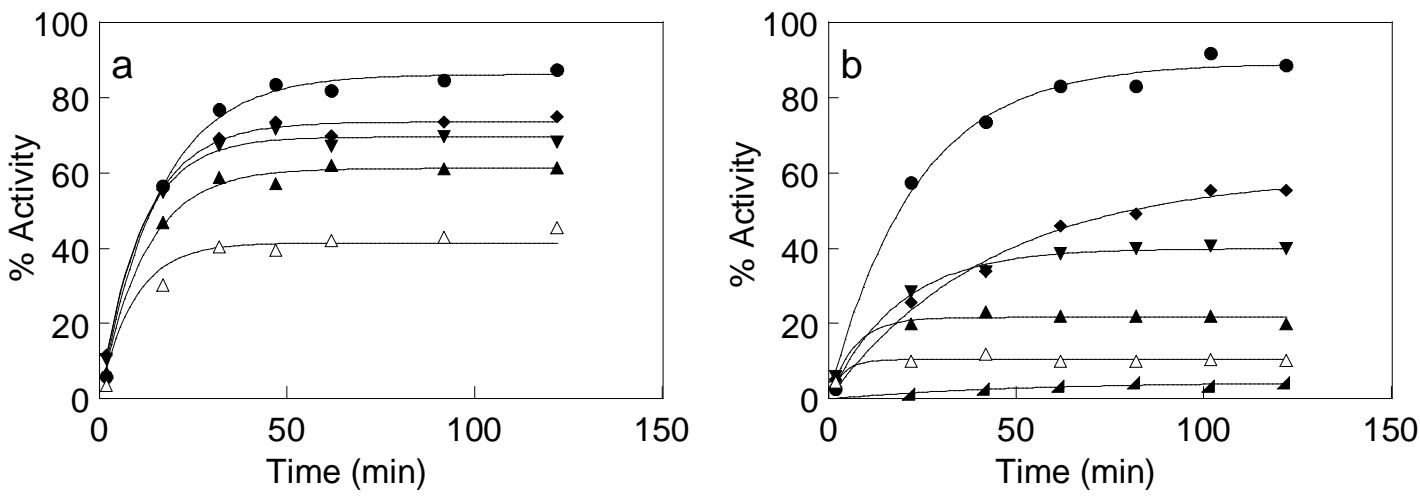

Figure 27. Folding of lysozyme $(0.1 \mathrm{mg} / \mathrm{mL})$ at $\mathrm{pH}$ 8.0: (a) under standard conditions or $0.2 \mathrm{mM}$ GSSG and various concentrations of para-substituted aromatic tetraethylene glycol dithiol (15); (b) under standard conditions or $2 \mathrm{mM}$ GSSG and various concentrations of para-substituted aromatic tetraethylene glycol dithiol (15). (a) (•) 7

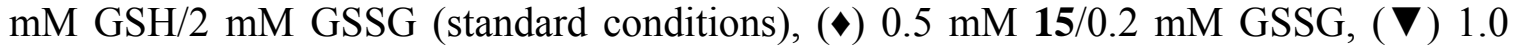

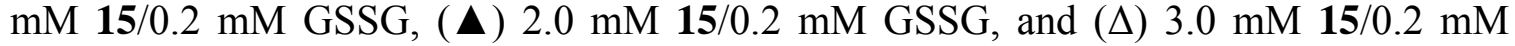

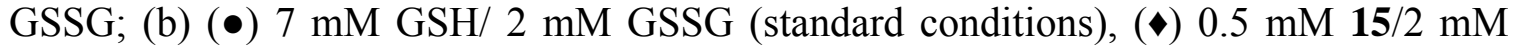

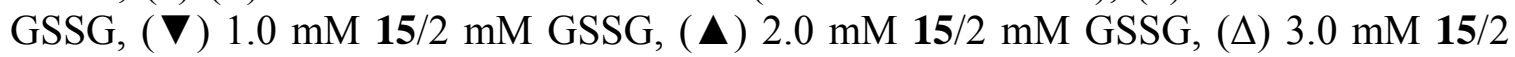
$\mathrm{mM}$ GSSG, and (A) $10.0 \mathrm{mM} \mathrm{15/2} \mathrm{mM}$ GSSG. 
Table 3. Folding of lysozyme with para-substituted aromatic triethylene glycol dithiol (14) at $\mathrm{pH} 7.0$ and 8.0

\begin{tabular}{|c|c|c|c|}
\hline \multicolumn{4}{|c|}{ pH 7.0} \\
\hline Redox buffer & $A(\%)$ & $k\left(\min ^{-1}\right)$ & $A^{*} k(\% / \mathrm{min})$ \\
\hline $0.5 \mathrm{mM} 14 / 0.2 \mathrm{mM}$ GSSG & 57 & 0.025 & 1.4 \\
\hline $1 \mathrm{mM} \mathrm{14/0.2} \mathrm{mM} \mathrm{GSSG}$ & 50 & 0.028 & 1.4 \\
\hline $2 \mathrm{mM} \mathrm{14} / 0.2 \mathrm{mM}$ GSSG & 36 & 0.024 & 0.9 \\
\hline $3 \mathrm{mM} \mathrm{14} / 0.2 \mathrm{mM} \mathrm{GSSG}$ & 23 & 0.020 & 0.5 \\
\hline $10 \mathrm{mM}$ 14/0.2 mM GSSG & 0.5 & 0.058 & 0.03 \\
\hline $0.5 \mathrm{mM} \mathrm{14} / 2 \mathrm{mM} \mathrm{GSSG}$ & 41 & 0.012 & 0.5 \\
\hline $1 \mathrm{mM} \mathrm{14/2} \mathrm{mM} \mathrm{GSSG}$ & 44 & 0.019 & 0.9 \\
\hline $2 \mathrm{mM} \mathrm{14/2} \mathrm{mM}$ GSSG & 40 & 0.032 & 1.3 \\
\hline $3 \mathrm{mM} \mathrm{14} / 2 \mathrm{mM}$ GSSG & 34 & 0.035 & 1.2 \\
\hline $7 \mathrm{mM} \mathrm{GSH} / 2 \mathrm{mM} \mathrm{GSSG}$ & 83 & 0.010 & 0.9 \\
\hline \multicolumn{4}{|c|}{ pH 8.0} \\
\hline Redox buffer & $A(\%)$ & $k\left(\min ^{-1}\right)$ & $A * k(\% / \mathrm{min})$ \\
\hline $0.5 \mathrm{mM} \mathrm{14} / 0.2 \mathrm{mM}$ GSSG & 63 & 0.076 & 4.8 \\
\hline $1 \mathrm{mM} \mathrm{14} / 0.2 \mathrm{mM} \mathrm{GSSG}$ & 51 & 0.082 & 4.2 \\
\hline $2 \mathrm{mM} \mathrm{14} / 0.2 \mathrm{mM} \mathrm{GSSG}$ & 31 & 0.088 & 2.7 \\
\hline $3 \mathrm{mM} \mathrm{14} / 0.2 \mathrm{mM} \mathrm{GSSG}$ & 16 & 0.103 & 1.6 \\
\hline $0.5 \mathrm{mM} \mathrm{14} / 2 \mathrm{mM} \mathrm{GSSG}$ & 61 & 0.036 & 22 \\
\hline $1 \mathrm{mM} \mathrm{14} / 2 \mathrm{mM}$ GSSG & 43 & 0.069 & 3.0 \\
\hline $2 \mathrm{mM} 14 / 2 \mathrm{mM}$ GSSG & 16 & 0.285 & 4.5 \\
\hline $3 \mathrm{mM} 14 / 2 \mathrm{mM}$ GSSG & 2 & 0.820 & 1.5 \\
\hline $7 \mathrm{mM} \mathrm{GSH} / 2 \mathrm{mM}$ GSSG & 85 & 0.070 & 6.0 \\
\hline
\end{tabular}

An increase in the overall yield of native protein with both series of aromatic dithiols (11, 12, 14, and 15) was expected, because of the presence of the second thiol group on the aliphatic chain in comparison with $7 \mathrm{mM}$ GSH and $2 \mathrm{mM}$ GSSG. However, a general 
decreased in the overall yield of native protein with both series of aromatic dithiols (11,

12, 14, and 15) was observed.

Table 4. Folding of lysozyme with para-substituted aromatic tetraethylene glycol dithiol (15) at $\mathrm{pH} 7.0$ and 8.0

\begin{tabular}{|c|c|c|c|}
\hline \multicolumn{4}{|c|}{ pH 7.0} \\
\hline Redox buffer & $A(\%)$ & $k\left(\min ^{-1}\right)$ & $A^{*} k(\% / \mathrm{min})$ \\
\hline $0.5 \mathrm{mM} 15 / 0.2 \mathrm{mM}$ GSSG & 39 & 0.038 & 1.5 \\
\hline $1 \mathrm{mM} \mathrm{15} / 0.2 \mathrm{mM}$ GSSG & 40 & 0.050 & 2.0 \\
\hline $3 \mathrm{mM} \mathrm{15} / 0.2 \mathrm{mM}$ GSSG & 36 & 0.045 & 1.6 \\
\hline 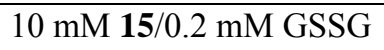 & 13 & 0.066 & 0.8 \\
\hline $0.5 \mathrm{mM} \mathrm{15} / 2 \mathrm{mM} \mathrm{GSSG}$ & 54 & 0.008 & 0.4 \\
\hline $1 \mathrm{mM} \mathrm{15} / 2 \mathrm{mM}$ GSSG & 58 & 0.017 & 1.0 \\
\hline $2 \mathrm{mM} \mathrm{15/2} \mathrm{mM} \mathrm{GSSG}$ & 49 & 0.040 & 2.0 \\
\hline $3 \mathrm{mM} \mathrm{15} / 2 \mathrm{mM}$ GSSG & 38 & 0.054 & 2.0 \\
\hline $10 \mathrm{mM} \mathrm{15/2} \mathrm{mM} \mathrm{GSSG}$ & 0 & 0.081 & 0.02 \\
\hline $7 \mathrm{mM} \mathrm{GSH} / 2 \mathrm{mM}$ GSSG & 83 & 0.011 & 0.9 \\
\hline \multicolumn{4}{|c|}{ pH 8.0} \\
\hline Redox buffer & $A(\%)$ & $k\left(\min ^{-1}\right)$ & $A^{*} k(\% / \mathrm{min})$ \\
\hline $0.5 \mathrm{mM} \mathrm{15/0.2} \mathrm{mM} \mathrm{GSSG}$ & 73 & 0.087 & 6.4 \\
\hline 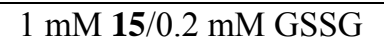 & 69 & 0.096 & 6.7 \\
\hline $2 \mathrm{mM} \mathrm{15/0.2} \mathrm{mM} \mathrm{GSSG}$ & 61 & 0.086 & 5.3 \\
\hline $3 \mathrm{mM} \mathrm{15} / 0.2 \mathrm{mM}$ GSSG & 43 & 0.072 & 3.1 \\
\hline $0.5 \mathrm{mM} \mathrm{15} / 2 \mathrm{mM}$ GSSG & 39 & 0.061 & 2.4 \\
\hline $1 \mathrm{mM} \mathrm{15/2} \mathrm{mM} \mathrm{GSSG}$ & 54 & 0.028 & 1.5 \\
\hline $2 \mathrm{mM} \mathrm{15/2} \mathrm{mM} \mathrm{GSSG}$ & 22 & 0.192 & 4.2 \\
\hline $3 \mathrm{mM} \mathrm{15} / 2 \mathrm{mM}$ GSSG & 10 & 0.354 & 3.7 \\
\hline $10 \mathrm{mM} \mathrm{15/2} \mathrm{mM}$ GSSG & 1 & 1.304 & 0.9 \\
\hline $7 \mathrm{mM} \mathrm{GSH} / 2 \mathrm{mM}$ GSSG & 86 & 0.064 & 5.6 \\
\hline
\end{tabular}




\subsubsection{Synthesis and folding studies with para-substituted aromatic diethylene glycol dithiol (13)}

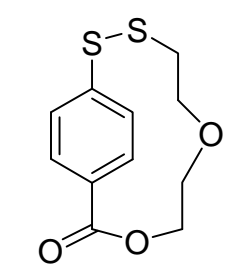

Diethylene disulfide

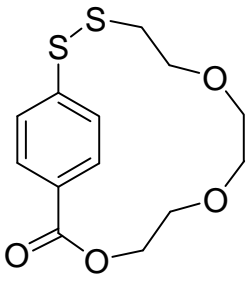

Triethylene disulfide

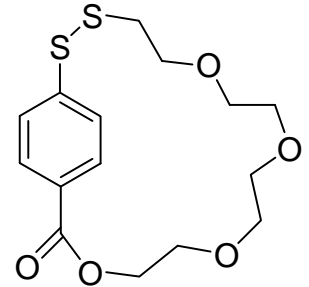

Tetraethylene disulfide

Figure 28. Stable cyclic structure

After performing the folding experiments above, similar trends in terms of folding yield with ortho- and para- series of aromatic dithiols $(\mathbf{1 1}, \mathbf{1 2}, \mathbf{1 4}$, and 15) was observed. I thought that the decrease in yield was as a result of the formation of stable cyclic disulfides with 11, 12, 14, and 15 (Figure 28, stable disulfides shown only for 14 and 15). In order to verify the hypothesis, para-substituted aromatic diethylene glycol dithiol (13) was synthesized as shown in Scheme 10 and assumed that dithiol $\mathbf{1 3}$ may form a less stable cyclic disulfide (Figure 28). Next, the folding studies with dithiol 13 was performed. The concentrations of dithiol 13 examined were in the range of 0.5 to $10 \mathrm{mM}$. The folding experiments were carried out in combination with either 0.2 or $2 \mathrm{mM} \mathrm{GSSG}$ at $\mathrm{pH}$ 8.0. (Table 5, Figure 29). However, dithiol 13 showed similar trends as the orthoand para- derivatives of tri- and tetraethylene glycol dithiols $(\mathbf{1 1}, \mathbf{1 2}, \mathbf{1 4}$, and 15). The yield decreased with increasing concentrations of dithiol 13. Thus, the decreases in yield may not be the result of the formation of a stable cyclic disulfide, but some other factor. Next, the role of the thiol present on the aliphatic chain was investigated. 

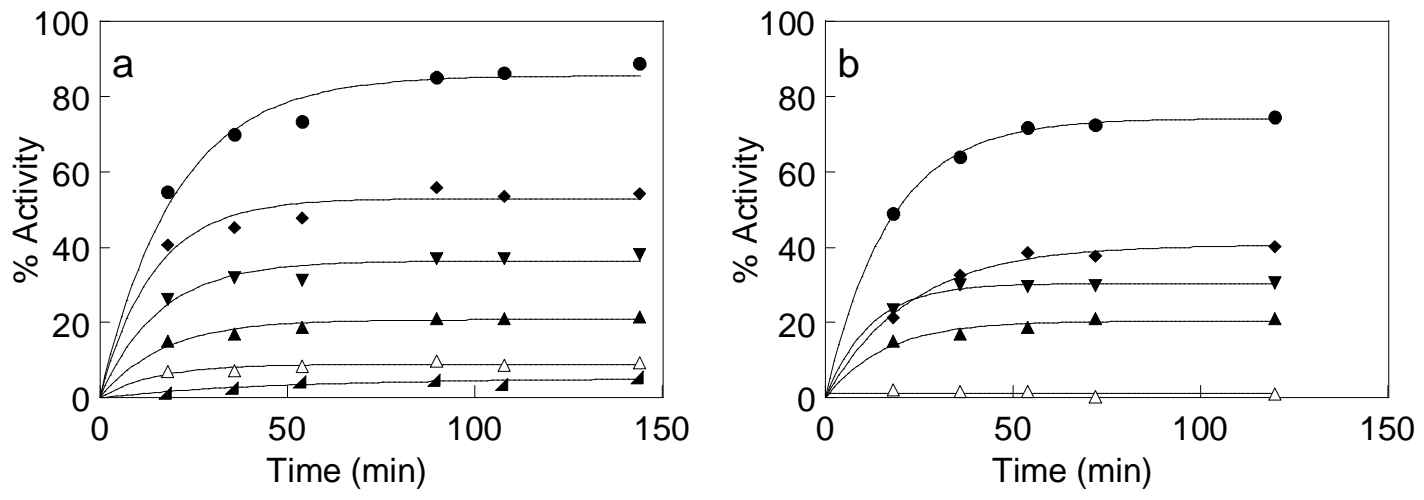

Figure 29. Folding of lysozyme $(0.1 \mathrm{mg} / \mathrm{mL})$ at $\mathrm{pH}$ 8.0: (a) under standard conditions or $0.2 \mathrm{mM} \mathrm{GSSG}$ and various concentrations of para-substituted aromatic diethylene glycol dithiol (13); (b) under standard conditions or 2 mM GSSG and various concentrations of para-substituted aromatic diethylene glycol dithiol (13). (a) (•) $7 \mathrm{mM} \mathrm{GSH} / 2 \mathrm{mM}$

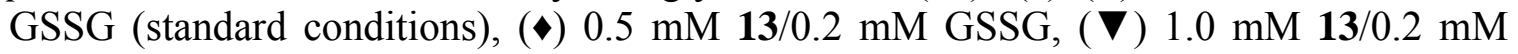

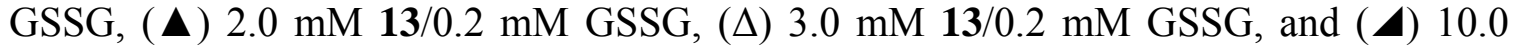
mM 13/0.2 mM GSSG; (b) (•) $7 \mathrm{mM} \mathrm{GSH} / 2 \mathrm{mM} \mathrm{GSSG}$ (standard conditions), (•) 0.5 mM 13/2 mM GSSG, ( $) 1.0 \mathrm{mM} \mathrm{13/2} \mathrm{mM} \mathrm{GSSG,} \mathrm{( \Delta )} 2.0 \mathrm{mM} \mathrm{13/2} \mathrm{mM} \mathrm{GSSG},(\Delta)$ $3.0 \mathrm{mM} \mathrm{13} / 2 \mathrm{mM}$ GSSG, and (A) $10.0 \mathrm{mM} \mathrm{13/2} \mathrm{mM}$ GSSG.

Table 5. Folding of lysozyme with para-substituted aromatic diethylene glycol dithiol (13) at $\mathrm{pH} 8.0$

\begin{tabular}{|c|c|c|c|}
\hline Redox buffer & $\boldsymbol{A ~ ( \% ) ~}$ & $\boldsymbol{k}\left(\mathbf{m i n}^{\mathbf{- 1}}\right)$ & $\boldsymbol{A}^{*} \boldsymbol{k}(\mathbf{\%} / \mathbf{m i n})$ \\
\hline $0.5 \mathrm{mM} \mathrm{13} / 0.2 \mathrm{mM} \mathrm{GSSG}$ & 53 & 0.072 & 3.79 \\
\hline $1 \mathrm{mM} \mathrm{13} / 0.2 \mathrm{mM}$ GSSG & 36 & 0.066 & 2.39 \\
\hline $2 \mathrm{mM} \mathrm{13} / 0.2 \mathrm{mM} \mathrm{GSSG}$ & 21 & 0.065 & 1.33 \\
\hline $3 \mathrm{mM} \mathrm{13} / 0.2 \mathrm{mM} \mathrm{GSSG}$ & 9 & 0.08 & 0.71 \\
\hline $10 \mathrm{mM} \mathrm{13} / 0.2 \mathrm{mM} \mathrm{GSSG}$ & 0 & 0 & 0 \\
\hline $0.5 \mathrm{mM} \mathrm{13} / 2 \mathrm{mM} \mathrm{GSSG}$ & 53 & 0.023 & 1.21 \\
\hline $1 \mathrm{mM} \mathrm{13} / 2 \mathrm{mM} \mathrm{GSSG}$ & 35 & 0.055 & 1.79 \\
\hline $2 \mathrm{mM} \mathrm{13} / 2 \mathrm{mM} \mathrm{GSSG}$ & 14 & 0.131 & 4.06 \\
\hline $3 \mathrm{mM} \mathrm{13} / 2 \mathrm{mM} \mathrm{GSSG}$ & 1 & 2.849 & 0 \\
\hline $10 \mathrm{mM} \mathrm{13} / 2 \mathrm{mM} \mathrm{GSSG}$ & 0 & 0 & 4.34 \\
\hline $7 \mathrm{mM} \mathrm{GSH} / 2 \mathrm{mM} \mathrm{GSSG}$ & 85 & 0.051 & \\
\hline
\end{tabular}




\subsubsection{Synthesis and folding studies with aromatic triethylene glycol monothiol (61)}

To check the role of aliphatic thiol on the yield of lysozyme, aromatic triethylene glycol monothiol (61) was synthesized, a compound with a thiol group on the aliphatic chain and without a thiol group on the aromatic ring. Monothiol 61 was synthesized by treating readily available benzoyl chloride (59) with triethylene glycol disulfide (38) in the presence of triethylamine to give compound 60. Compound 60 was purified by column chromatography and then reduced with DTT in the presence of triethylamine to form monothiol 61 (Scheme 11).

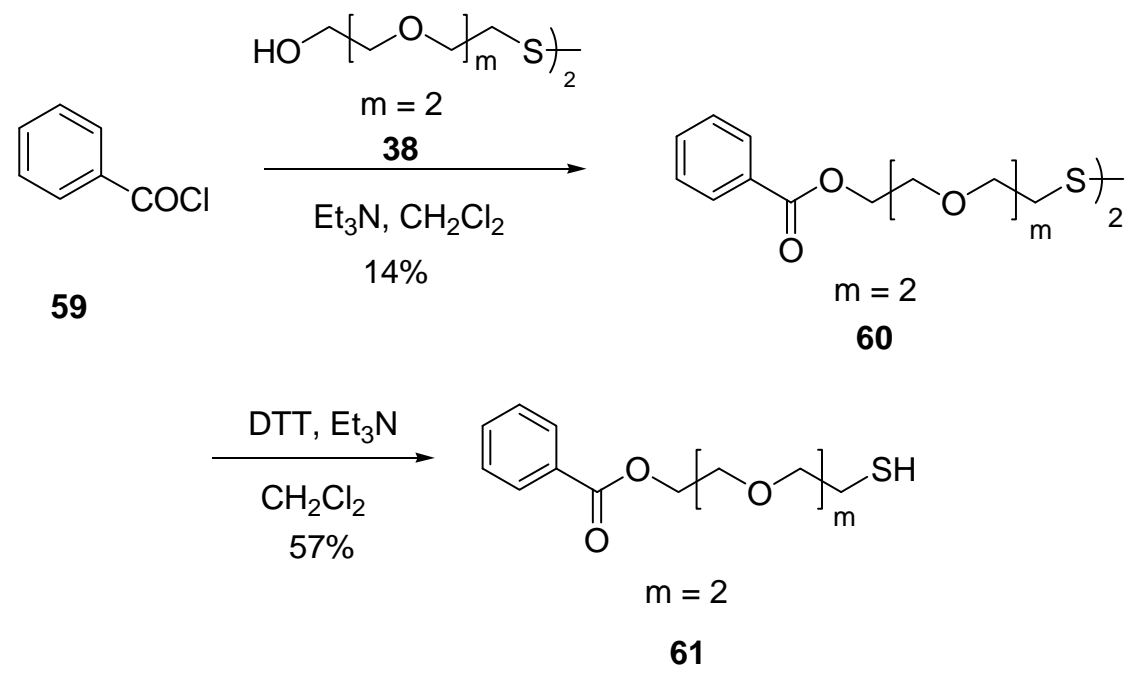

Scheme 11. Synthesis of aromatic triethylene glycol monothiol (61)

Monothiol 61 was partially soluble in $0.1 \mathrm{M}$ Trizma base buffer ( $\mathrm{pH} 8.0)$, hence, its solubility was determined by Ellman's method. ${ }^{141}$ The solubility of monothiol $\mathbf{6 1}$ was found to be $2 \mathrm{mM}$ at $\mathrm{pH} 8.0$. Thus, the concentrations of monothiol $\mathbf{6 1}$ examined were $0.25,0.5$, and $1 \mathrm{mM}$. The folding experiments were performed in the presence of either 0.2 or $2 \mathrm{mM} \mathrm{GSSG}$ at $\mathrm{pH} 8.0$ (Table 6, Figure 30). Monothiol 61 showed not only a 
decrease in the yield but also a decrease in the rate as compared to $7 \mathrm{mM} \mathrm{GSH} / 2 \mathrm{mM}$ GSSG.

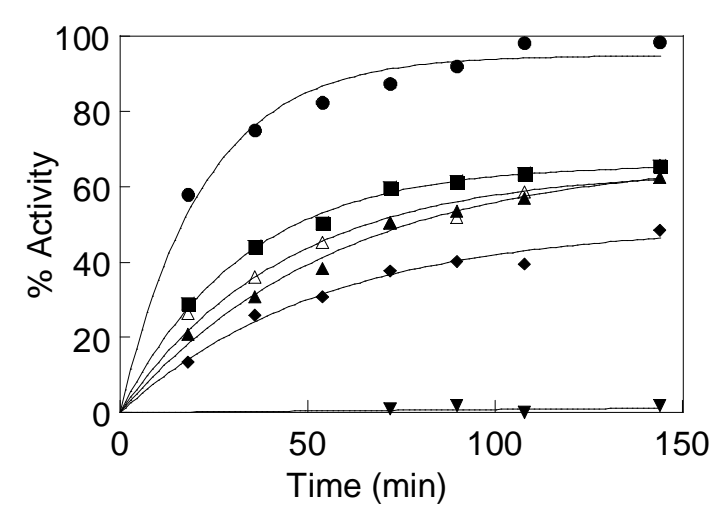

Figure 30. Folding of lysozyme $(0.1 \mathrm{mg} / \mathrm{mL})$ at $\mathrm{pH} 8.0$; under standard conditions or 0.2 $\mathrm{mM} \mathrm{GSSG}$ and various concentrations of aromatic triethylene glycol monothiol (61) or 2 $\mathrm{mM} \mathrm{GSSG}$ and various concentrations of aromatic triethylene glycol monothiol (61). (•)

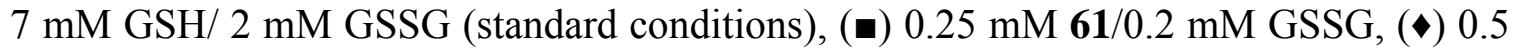

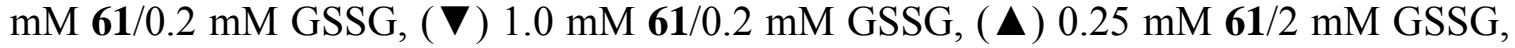
and $(\Delta) 0.5 \mathrm{mM}$ 61/2 $\mathrm{mM}$ GSSG.

Table 6. Folding of lysozyme with aromatic triethylene glycol monothiol (61) at $\mathrm{pH} 8.0$

\begin{tabular}{|c|c|c|c|}
\hline Redox buffer & $\boldsymbol{A ~ ( \% )}$ & $\boldsymbol{k}\left(\mathbf{m i n}^{\mathbf{- 1}}\right)$ & $\boldsymbol{A}^{*} \boldsymbol{k} \mathbf{( \% / m i n )}$ \\
\hline $0.25 \mathrm{mM} \mathrm{61} / 0.2 \mathrm{mM} \mathrm{GSSG}$ & 68 & 0.028 & 1.9 \\
\hline $0.5 \mathrm{mM} \mathrm{61} / 0.2 \mathrm{mM} \mathrm{GSSG}$ & 49 & 0.019 & 1.0 \\
\hline $1 \mathrm{mM} \mathrm{61} / 0.2 \mathrm{mM} \mathrm{GSSG}$ & 2 & 0.012 & 0.02 \\
\hline $0.25 \mathrm{mM} \mathrm{61} / 2 \mathrm{mM} \mathrm{GSSG}$ & 65 & 0.019 & 1.3 \\
\hline $0.5 \mathrm{mM} \mathrm{61} / 2 \mathrm{mM} \mathrm{GSSG}$ & 54 & 0.034 & 1.9 \\
\hline $7 \mathrm{mM} \mathrm{GSH} / 2 \mathrm{mM}$ GSSG & 86 & 0.055 & 4.7 \\
\hline
\end{tabular}

4.2.1.8 Folding studies with triethylene glycol monothiol (36)<smiles>OCCOCCOCCS</smiles>

36

Triethylene glycol monothiol (36) 

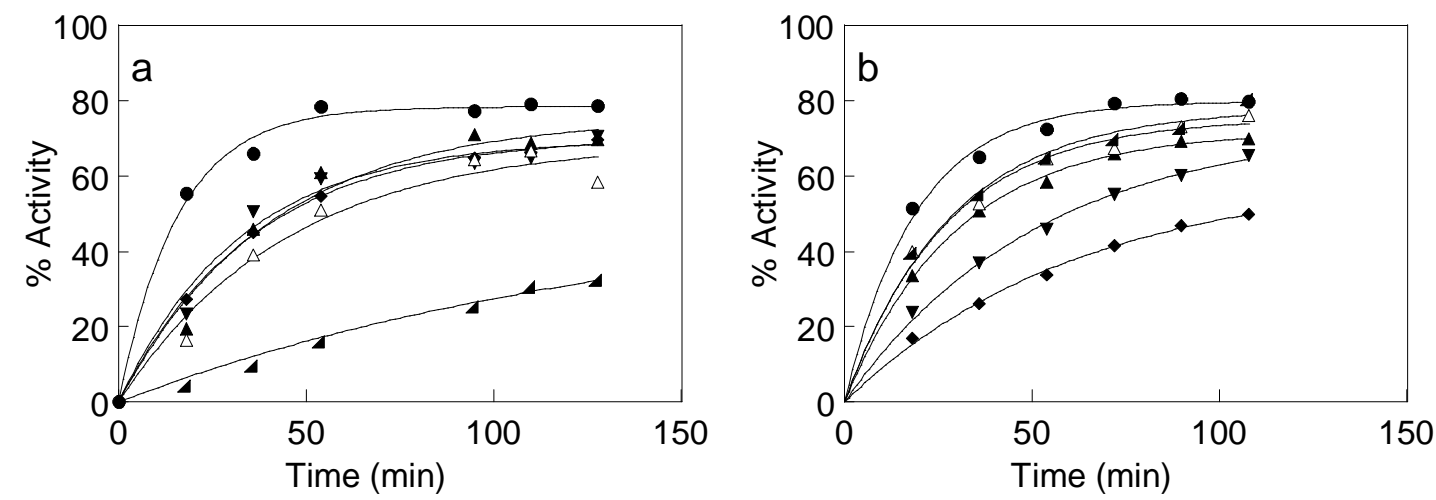

Figure 31. Folding of lysozyme $(0.1 \mathrm{mg} / \mathrm{mL})$ at $\mathrm{pH}$ 8.0: (a) under standard conditions or $0.2 \mathrm{mM} \mathrm{GSSG}$ and various concentrations of triethylene glycol monothiol (36); (b) under standard conditions or $2 \mathrm{mM} \mathrm{GSSG}$ and various concentrations of triethylene glycol monothiol (36). (a) (•) $7 \mathrm{mM} \mathrm{GSH} / 2 \mathrm{mM}$ GSSG (standard conditions), ( $) 0.5 \mathrm{mM}$ 36/0.2 mM GSSG, ( $\boldsymbol{\nabla}) 1.0 \mathrm{mM}$ 36/0.2 mM GSSG, ( $\Delta$ ) $2.0 \mathrm{mM} \mathrm{36/0.2} \mathrm{mM} \mathrm{GSSG,}(\Delta)$

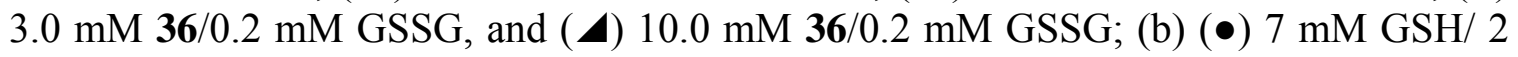

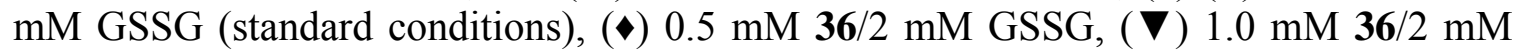

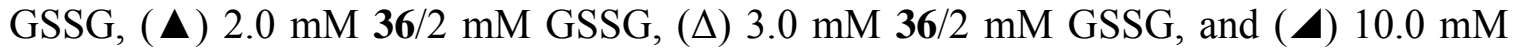
36/2 mM GSSG.

Table 7. Folding of lysozyme with triethylene glycol monothiol (36) at pH 8.0

\begin{tabular}{|c|c|c|c|}
\hline Redox buffer & $\boldsymbol{A ~ ( \% )}$ & $\boldsymbol{k}\left(\mathbf{m i n}^{\mathbf{- 1}}\right)$ & $\boldsymbol{A}^{*} \boldsymbol{k}(\mathbf{\%} / \mathbf{m i n})$ \\
\hline $0.5 \mathrm{mM} \mathrm{36} / 0.2 \mathrm{mM} \mathrm{GSSG}$ & 72 & 0.027 & 1.92 \\
\hline $1 \mathrm{mM} \mathrm{36} / 0.2 \mathrm{mM}$ GSSG & 72 & 0.029 & 2.08 \\
\hline $2 \mathrm{mM} \mathrm{36} / 0.2 \mathrm{mM} \mathrm{GSSG}$ & 77 & 0.025 & 1.88 \\
\hline $3 \mathrm{mM} \mathrm{36} / 0.2 \mathrm{mM} \mathrm{GSSG}$ & 68 & 0.024 & 1.60 \\
\hline $10 \mathrm{mM} \mathrm{36} / 0.2 \mathrm{mM} \mathrm{GSSG}$ & 53 & 0.008 & 0.43 \\
\hline $0.5 \mathrm{mM} \mathrm{36} / 2 \mathrm{mM} \mathrm{GSSG}$ & 58 & 0.018 & 1.0 \\
\hline $1 \mathrm{mM} \mathrm{36} / 2 \mathrm{mM}$ GSSG & 72 & 0.020 & 1.5 \\
\hline $2 \mathrm{mM} \mathrm{36} / 2 \mathrm{mM} \mathrm{GSSG}$ & 71 & 0.034 & 2.5 \\
\hline $3 \mathrm{mM} \mathrm{36} / 2 \mathrm{mM} \mathrm{GSSG}$ & 75 & 0.037 & 2.8 \\
\hline $10 \mathrm{mM} \mathrm{36} / 2 \mathrm{mM} \mathrm{GSSG}$ & 77 & 0.036 & 4.3 \\
\hline $7 \mathrm{mM} \mathrm{GSH} / 2 \mathrm{mM} \mathrm{GSSG}$ & 80 & 0.053 & \\
\hline
\end{tabular}

Finally, folding experiments with triethylene glycol monothiol (36), a compound without an aromatic ring were performed. Monothiol 36 was synthesized as shown in 
Scheme 7. Folding experiments were performed at $\mathrm{pH} 8.0$, using various concentrations of monothiol 36 in combination with either 0.2 or $2 \mathrm{mM} \mathrm{GSSG}$ (Table 7, Figure 31). Folding results with monothiol $\mathbf{3 6}$ showed similar folding yields and slightly lower folding rates as compared to GSH/GSSG, indicating similar behavior for both aliphatic thiols. The slower folding rate with monothiol $\mathbf{3 6}$ as compared to GSH may be because of the lower thiol $\mathrm{pK}_{\mathrm{a}}$ of monothiol 36 than that of the GSH.

In summary, ortho- and para-substituted aromatic ethylene glycol dithiols (11, 12, 14, and 15) showed a decrease in the yield of native lysozyme relative to the traditional conditions of GSH and GSSG. The initial hypothesis to explain the decrease in yield was that dithiols 11, 12, 14, and 15 may form stable cyclic disulfides. To test the hypothesis, para-substituted aromatic diethylene glycol dithiol (13) was synthesized and examined for its ability to fold reduced lysozyme. However, the initial hypothesis was not substantiated as dithiol $\mathbf{1 3}$ showed similar results in terms of yield as dithiols 11, 12, 14, and 15. Next, the role of the aliphatic thiol on the folding rate and yield of lysozyme was investigated. To check the role of aliphatic thiol, two compounds were synthesized, an aromatic triethylene glycol monothiol (61), a compound with a thiol on the aliphatic chain and without a thiol on the aromatic ring, and triethylene glycol monothiol (36). Both compounds (61 and 36) were then examined for their ability to fold reduced lysozyme. Monothiol $\mathbf{6 1}$ decreased the folding rate as well as yield of lysozyme. On the contrary, monothiol 36 showed similar results as GSH/GSSG. Thus, an aliphatic thiol group without an aromatic ring does not have any effect on the yield, whereas a thiol group on an aliphatic chain attached to an aromatic ring decreases the yield. To conclude, the decrease in the yield of native lysozyme with ortho- and para-substituted aromatic 
ethylene glycol dithiols $(\mathbf{1 1}, \mathbf{1 2}, \mathbf{1 4}$, and 15) may be because of the presence of the thiol group on an aliphatic chain attached to an aromatic ring.

\subsection{Di Quaternary ammonium aromatic dithiols (16 and 17)}

In the first series of aromatic dithiols (ortho- and para-series), one thiol group was present on the aromatic ring and a second thiol group was present on the aliphatic chain. The results of the folding experiments with ortho- and para-substituted aromatic ethylene glycol dithiols $(\mathbf{1 1}, \mathbf{1 2}, \mathbf{1 4}$, and $\mathbf{1 5})$ showed a decrease in the in vitro folding rate and yield as compared to standard conditions. Thus, a new series of aromatic dithiols were designed which should improve the in vitro folding rate and yield of lysozyme. The new series of aromatic dithiols were designed on the basis of a previously synthesized aromatic quaternary ammonium salt monothiol (Mono QAS) (3). Mono QAS 3 increased

the folding rate and yield of reduced lysozyme $(0.1 \mathrm{mg} / \mathrm{mL}$ as well at $1 \mathrm{mg} / \mathrm{mL}){ }^{37,38}$ Hence, new aromatic dithiols (16 and $\mathbf{1 7})$ similar in structure to the Mono QAS 3 were designed, having one thiol group on each of the two aromatic rings and the two aromatic rings connected by a hydrocarbon chain containing two quaternary ammonium groups. The criteria for selecting aromatic di quaternary ammonium salt dithiols (Di QAS) (16 and 17) were water solubility and low thiol $\mathrm{pK}_{\mathrm{a}}$ values, the same criteria as those used for dithiols 11, 12, 14, and 15. Furthermore, Di QAS 16 and Di QAS 17 were compared with Mono QAS 3 to check the effect of the second thiol group on folding rate and yield of a disulfide containing protein.

\subsubsection{Synthesis of aromatic di quaternary ammonium salt dithiols (16 and 17)}

Next, Di QAS 16 and Di QAS 17 were synthesized from brominated compound (25) in two simple steps, a coupling reaction followed by a hydrolysis reaction. The 
brominated compound (25) was synthesis as shown in Scheme 4. The brominated compound (25) was treated with $N, N, N^{\prime}, N^{\prime}$-tetramethyl-1,3-propane diamine (63) or $N, N, N^{\prime}, N^{\prime}$-tetramethyl-1,6-hexane diamine (65) to form compound (67) and (69), respectively. Compounds (67) and (69) were then hydrolyzed with 1:1 $\mathrm{HBr}_{2} \mathrm{H}_{2} \mathrm{O}$ at 130 ${ }^{\circ} \mathrm{C}$ for 90 min to give Di QAS 16 and Di QAS 17, respectively, (Scheme 12).
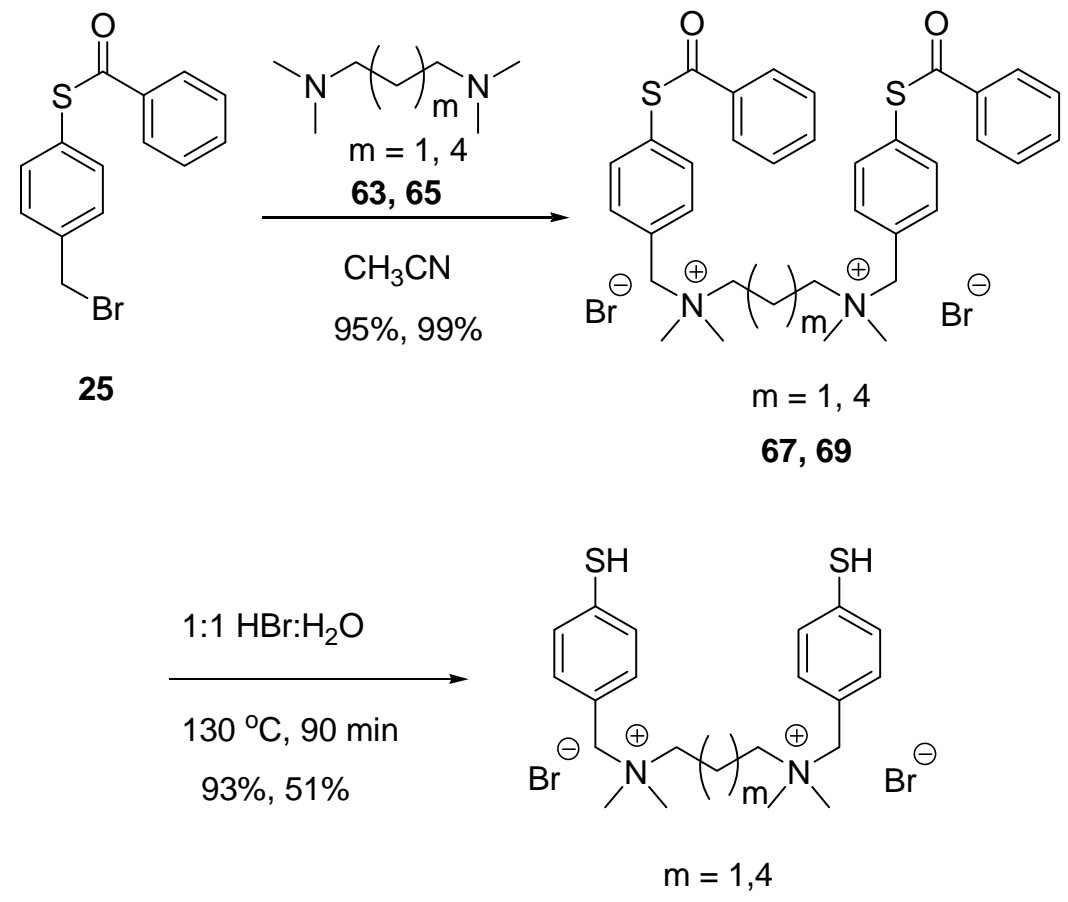

16,17

Scheme 12. Synthesis of aromatic di quaternary ammonium salt dithiols (16 and 17)

\subsubsection{Folding of lysozyme with Di QAS (16 and 17)}

Di QAS 16 and Di QAS 17 in various concentrations along with $2 \mathrm{mM}$ GSSG were utilized for the folding of reduced lysozyme $(0.1 \mathrm{mg} / \mathrm{mL})$ at $\mathrm{pH} 7.0$ and 8.0 . These folding experiments were conducted simultaneously with the standard condition, $7 \mathrm{mM}$ GSH and 2 mM GSSG. The folding of lysozyme was followed using the recovery of enzymatic activity as described for the dithiols $11,12,14$, and 15 . Initially, folding of 
Table 8. Folding of lysozyme $(0.1 \mathrm{mg} / \mathrm{mL})$ with DI QAS 16 and GSH at pH 7.0 and 8.0

\begin{tabular}{|c|c|c|c|}
\hline \multicolumn{4}{|c|}{ pH 7.0} \\
\hline Redox buffer & $A(\%)$ & $k\left(\min ^{-1}\right)$ & $A^{*} k(\% / \mathrm{min})$ \\
\hline $1 \mathrm{mM} \mathrm{16/2} \mathrm{mM} \mathrm{GSSG}$ & 87 & 0.010 & 0.9 \\
\hline 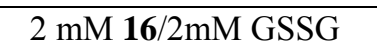 & 84 & 0.016 & 1.4 \\
\hline $3 \mathrm{mM} \mathrm{16} / 2 \mathrm{mM}$ GSSG & 87 & 0.025 & 2.2 \\
\hline $7 \mathrm{mM}$ 16/2 mM GSSG & 75 & 0.042 & 3.2 \\
\hline 10 mM 16/2 mM GSSG & 58 & 0.1 & 5.8 \\
\hline $7 \mathrm{mM} \mathrm{GSH} / 2 \mathrm{mM} \mathrm{GSSG}$ & 91 & 0.007 & 0.6 \\
\hline \multicolumn{4}{|c|}{ pH 8.0} \\
\hline Redox buffer & $A(\%)$ & $k\left(\min ^{-1}\right)$ & $A^{*} k(\% / \mathrm{min})$ \\
\hline $1 \mathrm{mM} \mathrm{16/2} \mathrm{mM} \mathrm{GSSG}$ & 94 & 0.013 & 1.2 \\
\hline $2 \mathrm{mM} \mathrm{16} / 2 \mathrm{mM}$ GSSG & 98 & 0.006 & 0.6 \\
\hline $3 \mathrm{mM} 16 / 2 \mathrm{mM}$ GSSG & 92 & 0.018 & 1.7 \\
\hline 7 mM 16/2 mM GSSG & 85 & 0.034 & 2.9 \\
\hline $10 \mathrm{mM} \mathrm{16} / 2 \mathrm{mM}$ GSSG & 61 & 0.065 & 4.0 \\
\hline $7 \mathrm{mM} \mathrm{GSH} / 2 \mathrm{mM}$ GSSG & 90 & 0.045 & 4.0 \\
\hline
\end{tabular}

reduced lysozyme was performed using 1, 2, 3, 7, and 10 mM Di QAS 16 or Di QAS 17 in the presence of $2 \mathrm{mM} \mathrm{GSSG}$ at $\mathrm{pH} 7.0$ and 8.0. Both Di QAS 16 and Di QAS 17 were soluble $(>100 \mathrm{mM})$ in $0.1 \mathrm{M}$ bis tris propane- $\mathrm{HCl}$ buffer $(\mathrm{pH} 7.0)$ and $0.1 \mathrm{M}$ Tris-HCl buffer ( $\mathrm{pH}$ 8.0). The folding of lysozyme in the presence of Di QAS 16 and Di QAS 17 was compared by fitting the data to a single exponential function $\left[y=A\left(1-\mathrm{e}^{-k t}\right)\right]$, similar to that used for the dithiols 11, 12, 14, and 15 (Tables 8 and 9). Preliminary studies suggested that at $\mathrm{pH}$ 7.0, Di QAS 16 and Di QAS 17 increased the folding rate significantly with increasing concentration as compared to GSH/GSSG. However, at pH 8.0, below $7 \mathrm{mM}$ Di QAS 16 and below $3 \mathrm{mM}$ of Di QAS 17 the folding rate was slower, 
while at $10 \mathrm{mM}$ of Di QAS 16 and above $7 \mathrm{mM}$ Di QAS 17 the folding rate was significantly faster as compared to GSH/GSSG. At pH 7.0 and 8.0, Di QAS 17 showed similar yields of native lysozyme at all concentrations as GSH/GSSG. However, with Di QAS 16 at both $\mathrm{pH} 7.0$ and 8.0, the folding yield decreased with increasing concentration as compared to GSH/GSSG.

Table 9. Folding of lysozyme $(0.1 \mathrm{mg} / \mathrm{mL})$ with DI QAS 17 and GSH at pH 7.0 and 8.0

\begin{tabular}{|c|c|c|c|}
\hline \multicolumn{4}{|c|}{ pH 7.0} \\
\hline Redox buffer & $A(\%)$ & $k\left(\min ^{-1}\right)$ & $A^{*} k(\% / \mathrm{min})$ \\
\hline $1 \mathrm{mM} \mathrm{17/2} \mathrm{mM} \mathrm{GSSG}$ & 73 & 0.013 & 0.9 \\
\hline 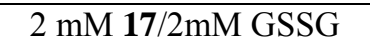 & 71 & 0.028 & 2.0 \\
\hline $3 \mathrm{mM} \mathrm{17/2} \mathrm{mM} \mathrm{GSSG}$ & 73 & 0.034 & 2.4 \\
\hline $7 \mathrm{mM} \mathrm{17/2} \mathrm{mM} \mathrm{GSSG}$ & 72 & 0.067 & 4.8 \\
\hline $10 \mathrm{mM} \mathrm{17/2} \mathrm{mM} \mathrm{GSSG}$ & 68 & 0.081 & 5.5 \\
\hline $7 \mathrm{mM} \mathrm{GSH} / 2 \mathrm{mM}$ GSSG & 67 & 0.008 & 0.6 \\
\hline \multicolumn{4}{|c|}{ рH 8.0} \\
\hline Redox buffer & $A(\%)$ & $k\left(\min ^{-1}\right)$ & $A^{*} k(\% / \mathrm{min})$ \\
\hline $1 \mathrm{mM} \mathrm{17/2} \mathrm{mM} \mathrm{GSSG}$ & 68 & 0.013 & 0.9 \\
\hline 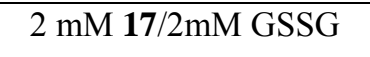 & 78 & 0.020 & 1.6 \\
\hline $3 \mathrm{mM} \mathrm{17/2} \mathrm{mM} \mathrm{GSSG}$ & 78 & 0.030 & 2.2 \\
\hline $7 \mathrm{mM} \mathrm{17/2} \mathrm{mM} \mathrm{GSSG}$ & 72 & 0.064 & 4.6 \\
\hline $10 \mathrm{mM}$ 17/2 mM GSSG & 73 & 0.083 & 6.0 \\
\hline $7 \mathrm{mM} \mathrm{GSH} / 2 \mathrm{mM} \mathrm{GSSG}$ & 72 & 0.040 & 2.9 \\
\hline
\end{tabular}

Next, folding experiments at high lysozyme concentration $(1 \mathrm{mg} / \mathrm{mL})$ using Di QAS 16 and Di QAS 17 at pH 7.0 and 8.0 were performed. Preliminary studies were performed to find the best concentration of Di QAS 16, Di QAS 17, and GSSG at both pH 7.0 and 8.0. Herein, GSSG was selected instead of the respective aromatic disulfides, 
as the aromatic disulfides were partially soluble in the $0.1 \mathrm{M}$ bis tris propane- $\mathrm{HCl}$ buffer $(\mathrm{pH} 7.0)$ and 0.1 M Tris-HCl buffer ( $\mathrm{pH} 8.0)$. Herein, the concentrations of Di QAS 16 and Di QAS 17 screened were 10, 20, 40, 70, and $100 \mathrm{mM}$, and the concentrations of GSSG examined were $0.5,1$, and $2 \mathrm{mM}$. In addition, the concentrations of Di QAS 16 examined with $2 \mathrm{mM}$ GSSG were 1, 2, 3, 7, and $10 \mathrm{mM}$. Concentrations of Di QAS 16 and Di QAS 17 were selected to screen a wide range of concentrations. At pH 7.0 and 8.0, the two best combinations of each of Di QAS 16/GSSG and Di QAS 17/GSSG were

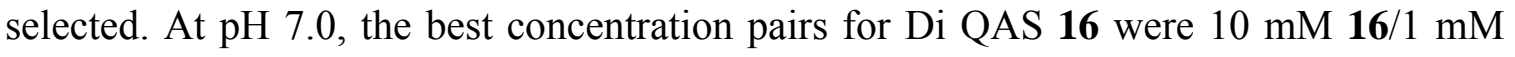
GSSG and $20 \mathrm{mM} \mathrm{16/1} \mathrm{mM} \mathrm{GSSG} \mathrm{whereas} \mathrm{at} \mathrm{pH} \mathrm{8.0,} \mathrm{the} \mathrm{best} \mathrm{concentration} \mathrm{pairs} \mathrm{were}$ $20 \mathrm{mM} \mathrm{16} / 1 \mathrm{mM}$ GSSG and $40 \mathrm{mM} \mathrm{16/1} \mathrm{mM} \mathrm{GSSG.} \mathrm{On} \mathrm{the} \mathrm{other} \mathrm{hand} \mathrm{at} \mathrm{pH} 7.0$, the best concentration pairs for Di QAS 17 were found to be $10 \mathrm{mM} \mathrm{17/0.5} \mathrm{mM} \mathrm{GSSG} \mathrm{and}$ $10 \mathrm{mM} \mathrm{17/1} \mathrm{mM} \mathrm{GSSG} \mathrm{whereas} \mathrm{at} \mathrm{pH} \mathrm{8.0,} \mathrm{the} \mathrm{best} \mathrm{pairs} \mathrm{were} 10 \mathrm{mM} \mathrm{17/1} \mathrm{mM} \mathrm{GSSG}$ and $20 \mathrm{mM}$ 17/1 $\mathrm{mM}$ GSSG.

To investigate the effect of the second thiol group on the folding rates and yields of reduced lysozyme, folding studies with Di QAS 16 and Di QAS 17 were performed simultaneously with Mono QAS 3. Folding of reduced lysozyme with various concentrations of Mono QAS 3 and various concentrations of GSSG were performed at both $\mathrm{pH} 7.0$ and 8.0 to find the best combination of Mono QAS 3/GSSG. Herein, the concentrations of Mono QAS 3 selected were 10, 20, 40, 70, and $100 \mathrm{mM}$ and the concentrations of GSSG selected were $0.5,1$, and $2 \mathrm{mM}$. The best combination pair at $\mathrm{pH}$ 7.0 and 8.0 was found to be $40 \mathrm{mM} \mathrm{3/1} \mathrm{mM} \mathrm{GSSG.}$

Next, comparative folding studies with the best combination pairs of Di QAS 16/GSSG, Di QAS 17/GSSG and Mono QAS 3/GSSG were conducted simultaneously 
with $7 \mathrm{mM} \mathrm{GSH} / 2 \mathrm{mM}$ GSSG at both $\mathrm{pH} 7.0$ and 8.0 (Figure 32) The data were fit to a single exponential function, $y=A\left(1-\mathrm{e}^{-k t}\right)$. The concentration of thiol which provided the highest value of the initial folding rate, $A^{*} k$, was defined as optimal. The $A, k$, and $A^{*} k$
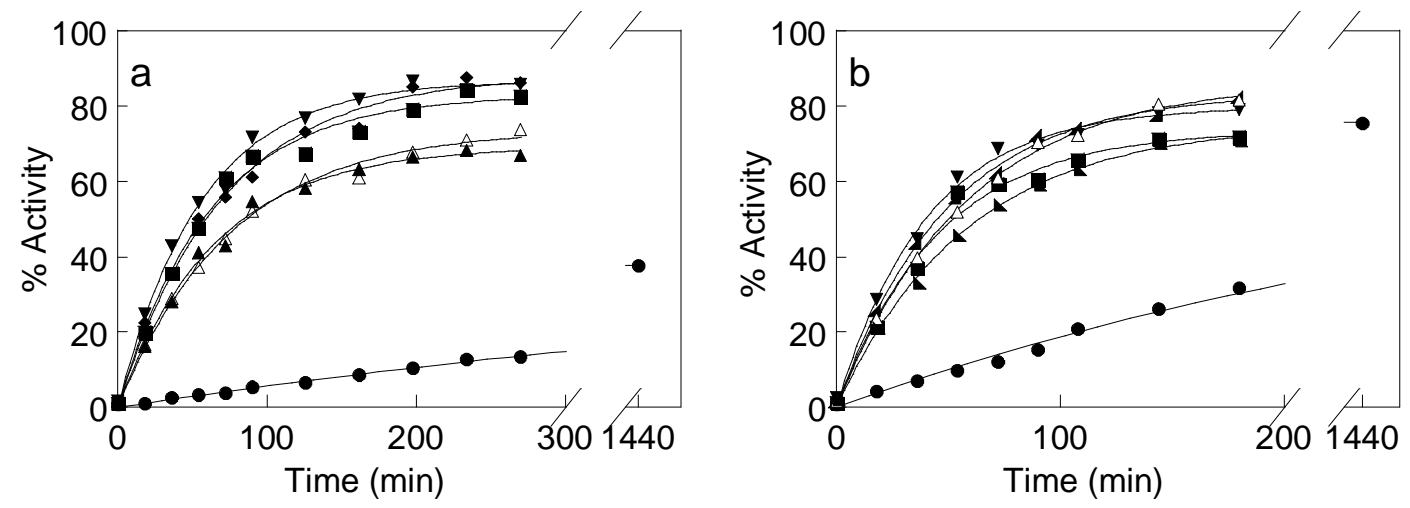

Figure 32. Folding of lysozyme $(1 \mathrm{mg} / \mathrm{mL})$ : (a) at $\mathrm{pH} 7.0,(\bullet) 7 \mathrm{mM} \mathrm{GSH} / 2 \mathrm{mM}$ GSSG

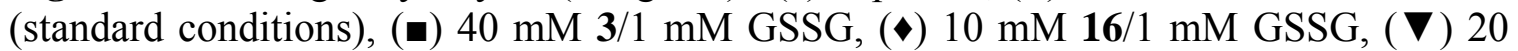

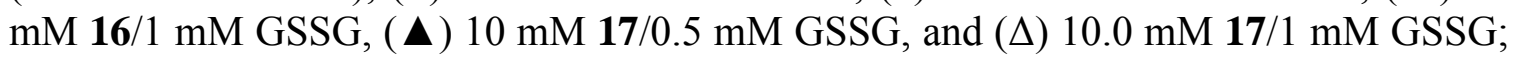
(b) at $\mathrm{pH} 8.0,(\bullet) 7 \mathrm{mM} \mathrm{GSH} / 2 \mathrm{mM} \mathrm{GSSG}$ (standard conditions), (ロ) $40 \mathrm{mM} \mathrm{3/1} \mathrm{mM}$

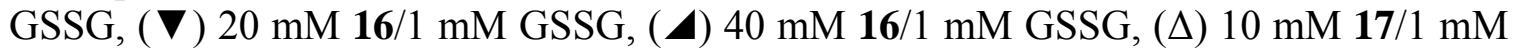
GSSG, and (-) $20.0 \mathrm{mM} \mathrm{17/1} \mathrm{mM} \mathrm{GSSG.}$

values at $\mathrm{pH} 7.0$ and 8.0 are shown in the table 10 . The results indicate a significant increase in the folding rate and yields for aromatic monothiol 3/GSSG, dithiol 16/GSSG, and dithiol 17/GSSG relative to GSH/GSSG at $\mathrm{pH}$ 7.0. The folding rate increase from 11 to 17 times and the yields increase from 26 to $42 \%$ relative to GSH/GSSG. The best folding rate was observed with $40 \mathrm{mM} \mathrm{3/1} \mathrm{mM} \mathrm{GSSG}$, whereas the best yield was observed with $20 \mathrm{mM} \mathrm{16/1} \mathrm{mM} \mathrm{GSSG.} \mathrm{While} \mathrm{comparing} \mathrm{aromatic} \mathrm{dithiols} \mathrm{versus}$ aromatic monothiols, aromatic monothiol (40 mM 3/1 mM GSSG) showed a significant increase in folding rate as compared to aromatic dithiols (10 mM 16/1 mM GSSG and 20 mM 16/1 mM GSSG). However, aromatic dithiol (20 mM 16/1 mM GSSG) significantly 
increase the yield of native lysozyme as compared to aromatic monothiol (40 mM 3/1 mM GSSG). The $A^{*} k$ values illustrate that best combination of aromatic thiol/GSSG concentrations at pH 7.0 were $40 \mathrm{mM} \mathrm{3/1} \mathrm{mM} \mathrm{GSSG} \mathrm{and} 20 \mathrm{mM} \mathrm{16/1} \mathrm{mM} \mathrm{GSSG.} \mathrm{The}$ $A^{*} k$ values for $40 \mathrm{mM} \mathrm{3/1} \mathrm{mM} \mathrm{GSSG}$ and $20 \mathrm{mM} \mathrm{16/1} \mathrm{mM} \mathrm{GSSG} \mathrm{were} 28$ and 24 times, respectively, greater than that of GSH/GSSG at $\mathrm{pH} 7.0$ and a protein concentration of $1 \mathrm{mg} / \mathrm{mL}$.

Table 10. Folding of lysozyme (1 mg/mL) with Mono QAS 3, Di QAS 16, Di QAS 17, and GSH at $\mathrm{pH} 7.0$ and 8.0

\begin{tabular}{|c|c|c|c|}
\hline \multicolumn{4}{|c|}{ pH 7.0} \\
\hline Redox buffer & $A(\%)$ & $k\left(\min ^{-1}\right)$ & $A^{*} k(\% / \mathrm{min})$ \\
\hline $40 \mathrm{mM} 3 / 1 \mathrm{mM}$ GSSG & $82 \pm 3$ & $0.017 \pm 0.002$ & $1.4 \pm 0.2$ \\
\hline $10 \mathrm{mM} \mathrm{16/1} \mathrm{mM} \mathrm{GSSG}$ & $83 \pm 5$ & $0.012 \pm 0.001$ & $1.0 \pm 0.2$ \\
\hline $20 \mathrm{mM} \mathrm{16} / 1 \mathrm{mM} \mathrm{GSSG}$ & $86 \pm 4$ & $0.015 \pm 0.003$ & $1.2 \pm 0.3$ \\
\hline $10 \mathrm{mM}$ 17/0.5 mM GSSG & $70 \pm 5$ & $0.013 \pm 0.002$ & $0.9 \pm 0.2$ \\
\hline $10 \mathrm{mM}$ 17/1 mM GSSG & $74 \pm 6$ & $0.011 \pm 0.001$ & $0.8 \pm 0.2$ \\
\hline $7 \mathrm{mM} \mathrm{GSH} / 2 \mathrm{mM} \mathrm{GSSG}$ & $44 \pm 2$ & $0.001 \pm 0.0002$ & $0.05 \pm 0.01$ \\
\hline \multicolumn{4}{|c|}{ pH 8.0} \\
\hline Redox buffer & $A(\%)$ & $k\left(\min ^{-1}\right)$ & $A^{*} \mathrm{k}(\% / \mathrm{min})$ \\
\hline $40 \mathrm{mM}$ 3/1 mM GSSG & $81 \pm 6$ & $0.018 \pm 0.002$ & $1.5 \pm 0.1$ \\
\hline $20 \mathrm{mM} \mathrm{16} / 1 \mathrm{mM}$ GSSG & $88 \pm 5$ & $0.022 \pm 0.003$ & $2.0 \pm 0.3$ \\
\hline $40 \mathrm{mM}$ 16/1 mM GSSG & $77 \pm 10$ & $0.023 \pm 0.010$ & $1.9 \pm 1.0$ \\
\hline $10 \mathrm{mM} \mathrm{17/1} \mathrm{mM} \mathrm{GSSG}$ & $78 \pm 6$ & $0.016 \pm 0.002$ & $1.3 \pm 0.2$ \\
\hline $20 \mathrm{mM} \mathrm{17/1} \mathrm{mM} \mathrm{GSSG}$ & $49 \pm 26$ & $0.017 \pm 0.002$ & $0.8 \pm 0.4$ \\
\hline $7 \mathrm{mM} \mathrm{GSH} / 2 \mathrm{mM}$ GSSG & $73 \pm 4$ & $0.003 \pm 0.001$ & $0.19 \pm 0.02$ \\
\hline
\end{tabular}

At $\mathrm{pH}$ 8.0, Figure 32 illustrates a substantial increase in the folding rate and yield with an Mono QAS 3 and Di QAS 16 as compared to GSH/GSSG (Table 10). The yield improvements were as much as $15 \%$, with the best being $20 \mathrm{mM} \mathrm{16/1} \mathrm{mM} \mathrm{GSSG.} \mathrm{The}$ 
folding rates with Mono QAS 3 and Di QAS 16 were increased up to eight times compared with $7 \mathrm{mM} \mathrm{GSH} / 2 \mathrm{mM} \mathrm{GSSG}$, the best being $40 \mathrm{mM} \mathrm{16/1} \mathrm{mM}$ GSSG. Comparison of aromatic monothiol (Mono QAS 3) versus aromatic dithiol (Di QAS 16) at $\mathrm{pH}$ 8.0, revealed that Di QAS 16 were better than Mono QAS 3 in terms of rate and yield. Aromatic dithiol (40 mM 16/1 mM GSSG) was better than aromatic monothiol (40 $\mathrm{mM} 3 / 1 \mathrm{mM} \mathrm{GSSG})$ in terms of folding rate, whereas aromatic dithiol (20 mM 16/1 mM GSSG) showed significant increase in yield as compared to aromatic monothiol (40 mM 3/1 mM GSSG). Overall, aromatic dithiol (20 mM 16/1 mM GSSG) was significantly better in terms of rate and yield as compared to aromatic monothiol $(40 \mathrm{mM} \mathrm{3/1} \mathrm{mM}$ GSSG). At higher concentration of Di QAS 17, $20 \mathrm{mM} \mathrm{17/1} \mathrm{mM} \mathrm{GSSG}$, although the rate was 6 times better than that of GSH/GSSG, the yield went down significantly. The decrease in the yield with $20 \mathrm{mM} \mathrm{17/1} \mathrm{mM} \mathrm{GSSG}$ was because of precipitation of the protein as seen by the naked eye. At $\mathrm{pH} 8.0$ and a protein concentration of $1 \mathrm{mg} / \mathrm{mL}, 20$ $\mathrm{mM}$ 16/1 mM GSSG and $40 \mathrm{mM}$ 16/1 mM GSSG showed as much as 10 times better $A^{*} k$ relative to $7 \mathrm{mM} \mathrm{GSH} / 2 \mathrm{mM}$ GSSG.

\section{4 pKa Values of aromatic monothiols and aromatic dithiols}

The $\mathrm{pK}_{\mathrm{a}}$ values of aromatic monothiols and aromatic dithiols were determined by measuring the change in the UV-vis spectra as a function of $\mathrm{pH}$. Buffers with $\mathrm{pH}$ values within 1.5 units of the predicted $\mathrm{pK}_{\mathrm{a}}$ values of the thiol were selected. The UV-vis spectrum of the thiol in each buffer was then obtained. The absorbance values at $\lambda_{\max }$ of either thiol or thiolate were then plotted against buffer $\mathrm{pH}$ and the resulting curve were analyzed by numerical analysis. The thiol $\mathrm{pK}_{\mathrm{a}}$ values of the ortho-substituted aromatic dithiols as well as triethylene aromatic monothiol were in the range of 6.8 to 7.2 (Table 
11, Figure 34). The thiol $\mathrm{pK}_{\mathrm{a}}$ values of the para-substituted aromatic dithiols as well as Di QAS aromatic dithiols were in the range of 5.3 to 5.5 (Table 11, Figure 33). Figure 34 illustrates UV-vis spectra of para-substituted aromatic tetraethylene glycol dithiol (15) in various $\mathrm{pH}$ buffers.

Table 11. pKa Values of aromatic monothiols and aromatic dithiols

\begin{tabular}{|c|c|c|}
\hline Compound & Substitution & $\mathrm{pK}_{\mathrm{a}}$ \\
\hline $\begin{array}{c}\text { Diethylene glycol dithiol (ortho) } \\
\mathbf{1 0}\end{array}$ & $o-\mathrm{HSPhCO}_{2}\left(\mathrm{CH}_{2}\right)_{2} \mathrm{O}\left(\mathrm{CH}_{2}\right)_{2} \mathrm{SH}$ & 7.1 \\
\hline $\begin{array}{l}\text { Triethylene glycol } \\
\text { dithiol (ortho) } \mathbf{1 1}\end{array}$ & $o-\mathrm{HSPhCO}_{2}\left(\mathrm{CH}_{2} \mathrm{CH}_{2} \mathrm{O}\right)_{2} \mathrm{CH}_{2} \mathrm{CH}_{2} \mathrm{SH}$ & 7.2 \\
\hline $\begin{array}{l}\text { Tetraethylene glycol dithiol } \\
\text { (ortho) } \mathbf{1 2}\end{array}$ & $o-\mathrm{HSPhCO}_{2}\left(\mathrm{CH}_{2} \mathrm{CH}_{2} \mathrm{O}\right)_{3} \mathrm{CH}_{2} \mathrm{CH}_{2} \mathrm{SH}$ & 7.0 \\
\hline $\begin{array}{l}\text { Diethylene glycol } \\
\text { dithiol (para) } 13\end{array}$ & $p$ - $\mathrm{HSPhCO}{ }_{2}\left(\mathrm{CH}_{2}\right)_{2} \mathrm{O}\left(\mathrm{CH}_{2}\right)_{2} \mathrm{SH}$ & 5.4 \\
\hline $\begin{array}{l}\text { Tetraethylene glycol } \\
\text { dithiol (para) } \mathbf{1 5}\end{array}$ & $p-\mathrm{HSPhCO}_{2}\left(\mathrm{CH}_{2} \mathrm{CH}_{2} \mathrm{O}\right)_{3} \mathrm{CH}_{2} \mathrm{CH}_{2} \mathrm{SH}$ & 5.5 \\
\hline Mono QAS (para) 3 & $p-\mathrm{HSPhCH}_{2} \mathrm{~N}^{+}\left(\mathrm{CH}_{3}\right)_{3}$ & 5.4 \\
\hline Di QAS (para) 16 & $\begin{array}{c}p-\mathrm{HSPhCH}_{2} \mathrm{~N}^{+}\left(\mathrm{CH}_{3}\right)_{2}\left(\mathrm{CH}_{2}\right)_{3} \mathrm{~N}^{+}\left(\mathrm{CH}_{3}\right)_{2} \mathrm{CH}_{2}-p- \\
\mathrm{PhSH}\end{array}$ & 5.3 \\
\hline Di QAS (para) 17 & $\begin{array}{c}p-\mathrm{HSPhCH}_{2} \mathrm{~N}^{+}\left(\mathrm{CH}_{3}\right)_{2}\left(\mathrm{CH}_{2}\right)_{6} \mathrm{~N}^{+}\left(\mathrm{CH}_{3}\right)_{2} \mathrm{CH}_{2}-p- \\
\mathrm{PhSH}\end{array}$ & 5.4 \\
\hline
\end{tabular}
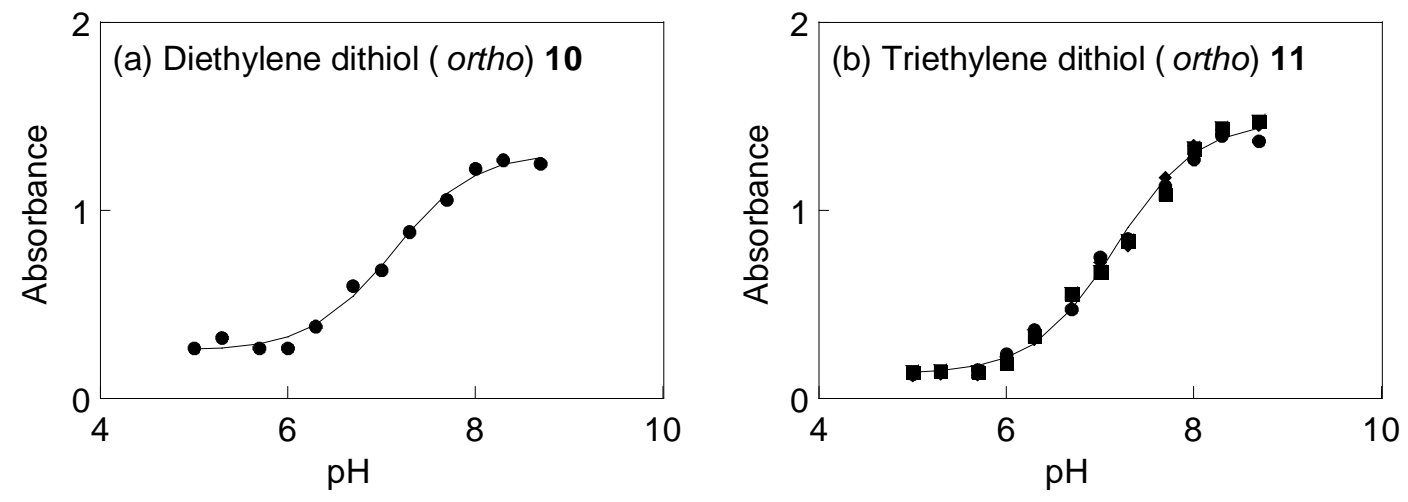

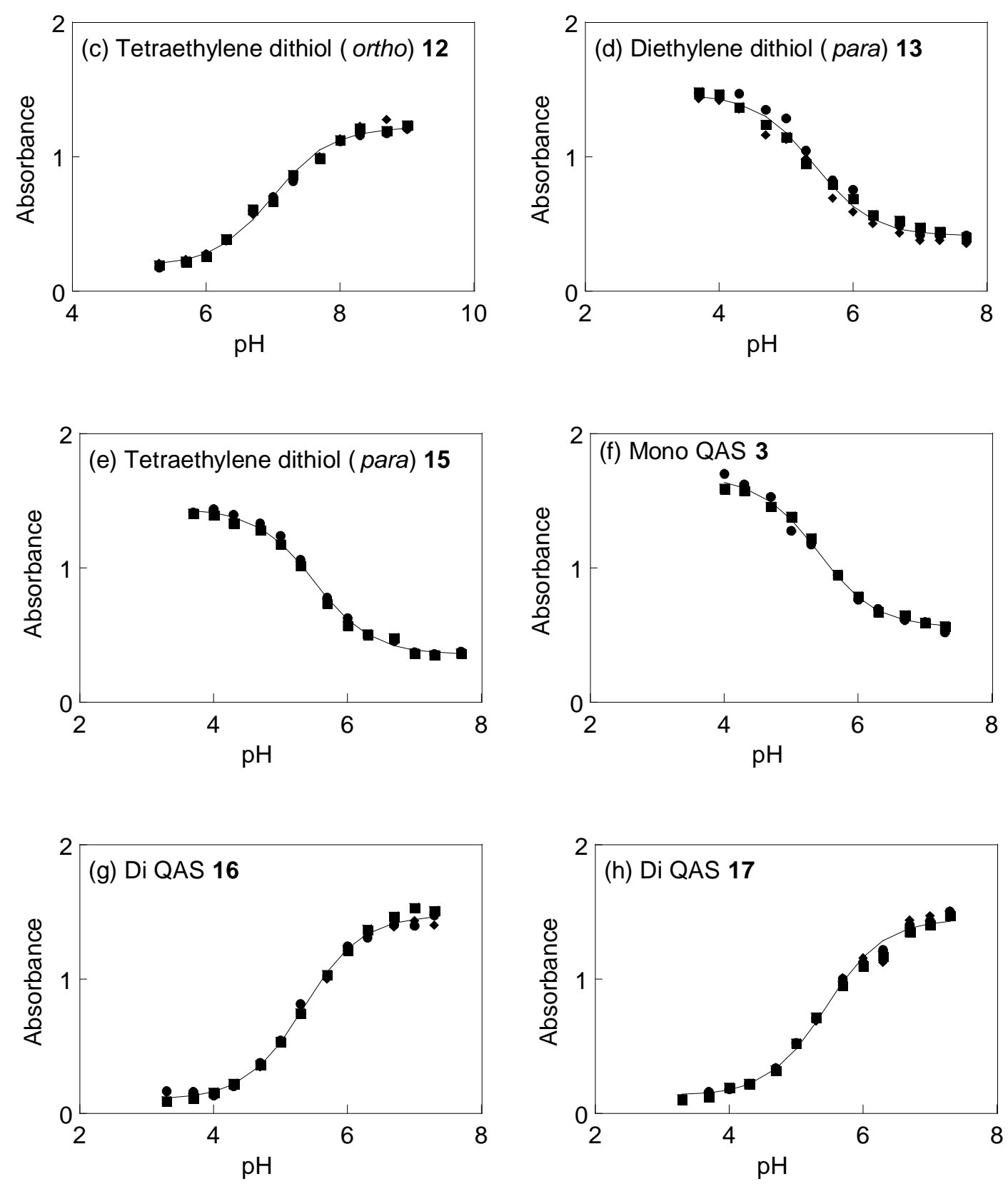

Figure 33. Determination of pKa values a) diethylene glycol dithiol (ortho) 10, b) triethylene glycol dithiol (ortho) 11, c) tetraethylene glycol dithiol ortho 12, d) diethylene glycol dithiol (para) 13, e) tetraethylene glycol dithiol (para) 15, f) Mono QAS 3, g) Di QAS 16, h) Di QAS 17. 


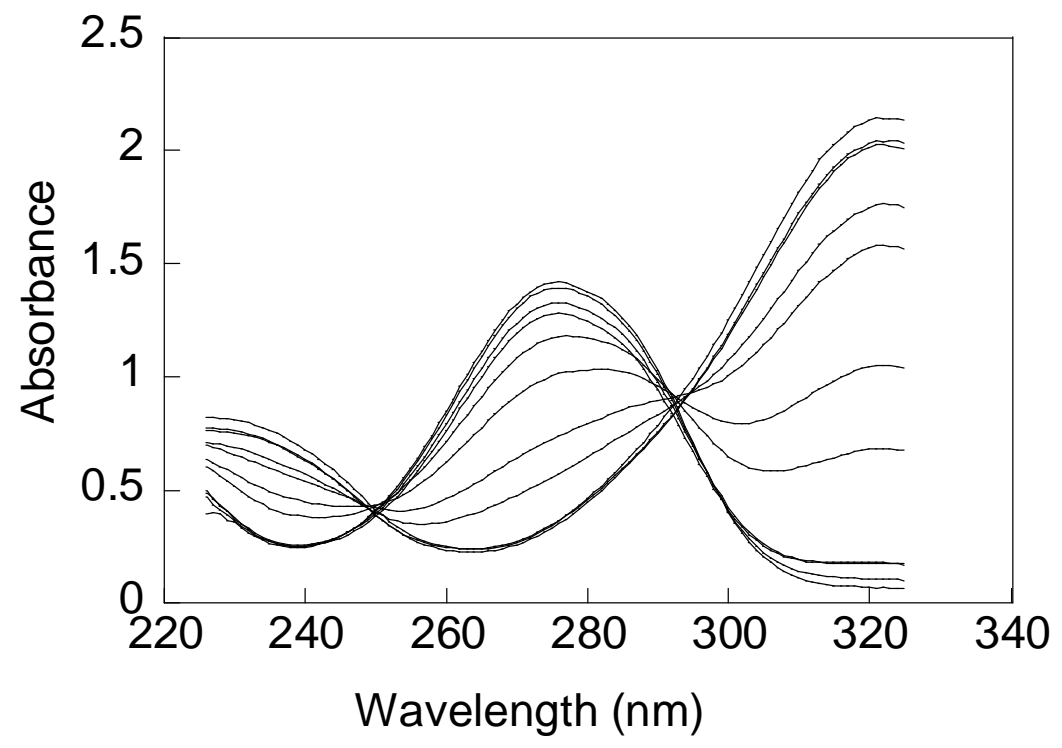

Figure 34. UV-vis spectra of para-substituted aromatic tetraethylene glycol dithiol (15) in various $\mathrm{pH}$ buffers. 


\section{Chapter 5}

\section{Conclusion}

\section{Project 1}

1) Aromatic monothiols, such as 4-mercaptobenzoic acid (1), 4mercaptobenzylphosphonic acid (2), quaternary ammonium salt (3), and 4mercaptobenzenesulfonic acid (4), and their corresponding disulfides (5-8) were synthesized on a multigram scale.

2) Disulfides of 4-mercaptobenzylphosphonic acid (6), quaternary ammonium salt (7), and 4-mercaptobenzenesulfonic acid (8) were utilized by Ms. Shweta Mandumula to fold BPTI, in particular $\mathrm{N}^{*}$ to $\mathrm{N}$. The results demonstrated that small molecule aromatic disulfides increase the folding rate constant of $\mathrm{N}^{*}$ to $\mathrm{N}$ by 100-3000 fold as compared to GSSG. Additionally, the results showed that $\mathrm{N}^{*}$ does undergo direct oxidation to $\mathrm{N}$, which was proposed earlier by Kim and Creighton not to occur.

3) The 4-Mercaptobenzylphosphonic acid (2), quaternary ammonium salt (3), and their corresponding disulfides (6 and 7) were utilized by Dr. David Madar to fold lysozyme at high protein concentration $(1 \mathrm{mg} / \mathrm{mL})$. The results revealed that aromatic thiols increase the folding rate up to 11 times and improve the yield between 20 and $40 \%$ as compared to GSH/GSSG at $\mathrm{pH}$ 7.0. Furthermore, at $\mathrm{pH} 8.0$, the folding rate was increased up to 7 times and the yield was improved up to $25 \%$ as compared to GSH/GSSG.

4) The disulfide of 4-mercaptobenzoic acid (5) was used to synthesize a series of parasubstituted aromatic ethylene glycol dithiols (13-15). 


\section{Project 2}

5) Two series of ortho- and para-substituted aromatic ethylene glycol dithiols (9-15) were synthesized. Dithiols (11-15) were then checked for effect on the folding of lysozyme at $\mathrm{pH} 7.0$ and 8.0. The ortho- and para-substituted aromatic ethylene glycol dithiols (11-15) showed a decrease in yield at both $\mathrm{pH} 7.0$ and 8.0 as compared to GSH/GSSG. The decrease in yield of native lysozyme may be because of the presence of a thiol group on an aliphatic chain attached to an aromatic ring.

\section{Project 3}

6) Finally, Di QAS 16 and Di QAS 17 were synthesized on a multigram scale in two easy steps from brominated intermediate (25) without any purification step except extraction.

7) Mono QAS 3, Di QAS 16, and Di QAS 17 were then tested for their ability to fold lysozyme at high protein concentration $(1 \mathrm{mg} / \mathrm{mL})$ at both $\mathrm{pH} 7.0$ and 8.0.

At $\mathrm{pH}$ 7.0, Mono QAS 3, Di QAS 16, and Di QAS 17 increased the folding rate and yield from 11 to 17 times and 26 to 42\%, respectively, relative to GSH/GSSG. While comparing aromatic dithiols versus aromatic monothiols, aromatic monothiol (40 mM 3/1 $\mathrm{mM}$ GSSG) showed a significant increase in folding rate as compared to aromatic dithiols (10 mM 16/1 mM GSSG and 20 mM 16/1 mM GSSG). However, aromatic dithol (20 mM 16/1 mM GSSG) significantly increase the yield of native lysozyme as compared to aromatic monothiol (40 mM 3/1 mM GSSG).

At pH 8.0, with Mono QAS (3), Di QAS 16, and Di QAS 17, the yield improvements were as much as $15 \%$, while the folding rate enhancements were up to 8 times compared to GSH/GSSG. Comparison of aromatic monothiol versus aromatic 
dithiols revealed that aromatic dithiol (16) was better than aromatic monothiol (3) in terms of rate and yield. Aromatic dithiol (40 mM 16/1 mM GSSG) was better than aromatic monothiol (40 mM 3/1 mM GSSG) in terms of folding rate, whereas aromatic dithiol (20 mM 16/1 mM GSSG) showed a significant increase in yield as compared to aromatic monothiol (40 mM 3/1 mM GSSG). Overall, aromatic dithiol (16) was significantly better in terms of rate and yield as compared to aromatic monothiol (3).

8) In conclusion, Di QAS (aromatic dithiol) significantly increase the in vitro folding yield of lysozyme as compared to Mono QAS (aromatic monothiol) at both $\mathrm{pH} 7.0$ and 8.0 and high protein concentration $(1 \mathrm{mg} / \mathrm{mL}$ ). Moreover, Di QAS (aromatic dithiol) and Mono QAS (aromatic monothiol) are better than aliphatic thiol such as glutathione in terms of folding rate and yield at both $\mathrm{pH} 7.0$ and 8.0 and high protein concentration (1 $\mathrm{mg} / \mathrm{mL}$ ). Thus, enhancement of the folding rate and yield achieved in in vitro protein folding at high protein concentration will decrease the volume of renaturation solution required for large scale processes and consequently reduce the processing time and cost. 


\section{REFERENCES}

(1) Voet, D.; Voet, J.; Pratt, W. C. Fundamentals of biochemistry Upgrade ed.; John and Wiley Sons Inc: New York, NY, USA, 2001.

(2) Griffiths, A.; Freeman, W. H. Modern genetic analysis; W. H. Freeman and Co., 1999.

(3) Stirling, P. C.; Lundin, V. F.; Leroux, M. R. Getting a grip on non-native proteins. EMBO Rep. 2003, 4, (6), 565-570.

(4) Gough, J. D.; Williams, R. H., Jr.; Donofrio, A. E.; Lees, W. J. Folding disulfidecontaining proteins faster with an aromatic thiol. J. Am. Chem. Soc. 2002, 124, (15), 3885-3892.

(5) Wedemeyer, W. J.; Welker, E.; Narayan, M.; Scheraga, H. A. Disulfide bonds and protein folding. Biochemistry 2000, 39, (15), 4207-4216.

(6) Gregersen, N.; Bross, P.; Jorgensen, M. M.; Corydon, T. J.; Andresen, B. S. Defective folding and rapid degradation of mutant proteins is a common disease mechanism in genetic disorders. J. Inherited Metab. Dis. 2000, 23, (5), 441-447.

(7) Radford, S. E.; Dobson, C. M. From computer simulations to human disease: Emerging themes in protein folding. Cell (Cambridge, Mass.) 1999, 97, (3), 291298.

(8) Chiti, F.; Dobson, C. M. Protein misfolding, functional amyloid, and human disease. Annu. Rev. Biochem. 2006, 75, 333-366.

(9) Soto, C. Alzheimer's and prion disease as disorders of protein conformation: Implications for the design of novel therapeutic approaches. J. Mol. Med. (Berlin) 1999, 77, (5), 412-418.

(10) Soto, C. Protein misfolding and disease; protein refolding and therapy. FEBS Lett. 2001, 498, (2-3), 204-207.

(11) Carrell, R. W.; Lomas, D. A. Conformational disease. Lancet 1997, 350, (9071), 134-138.

(12) Dobson, C. M. Protein misfolding, evolution and disease. Trends Biochem. Sci. 1999, 24, (9), 329-332.

(13) Carrell, R. W.; Gooptu, B. Conformational changes and disease - serpins, prions and alzheimer's. Curr. Opin. Struct. Biol. 1998, 8, (6), 799-809. 
(14) Thomas, P. J.; Qu, B.-H.; Pedersen, P. L. Defective protein folding as a basis of human disease. Trends Biochem. Sci. 1995, 20, (11), 456-459.

(15) Miller, W. L.; Baxter, J. D. Recombinant DNA. A new source of insulin. Diabetologia 1980, 18, (6), 431-436.

(16) De Bernardez Clark, E. Refolding of recombinant proteins. Curr. Opin. Biotechnol. 1998, 9, (2), 157-163.

(17) Taylor, G.; Hoare, M.; Gray, D. R.; Marston, F. A. O. Size and density of protein inclusion bodies. Bio/Technology 1986, 4, (6), 553-557.

(18) Rudolph, R.; Lilie, H. In vitro folding of inclusion body proteins. Faseb J. 1996, 10, (1), 49-56.

(19) Hagel, P.; Gerding, J. J.; Fieggen, W.; Bloemendal, H. Cyanate formation in solutions of urea. I. Calculation of cyanate concentrations at different temperature and ph. Biochim Biophys Acta 1971, 243, (3), 366-373.

(20) Schoemaker, J. M.; Brasnett, A. H.; Marston, F. A. O. Examination of calf prochymosin accumulation in escherichia coli: Disulfide linkages are a structural component of prochymosin-containing inclusion bodies. Embo J. 1985, 4, (3), 775-780.

(21) De Bernardez Clark, E. Protein refolding for industrial processes. Curr. Opin. Biotechnol. 2001, 12, (2), 202-207.

(22) Buchner, J.; Rudolph, R. Renaturation, purification and characterization of recombinant fab-fragments produced in E. coli. Biotechnology (N Y) 1991, 9, (2), 157-162.

(23) Tsuji, T.; Nakagawa, R.; Sugimoto, N.; Fukuhara, K. Characterization of disulfide bonds in recombinant proteins: Reduced human interleukin 2 in inclusion bodies and its oxidative refolding. Biochemistry 1987, 26, (11), 3129-3134.

(24) Halenbeck, R.; Kawasaki, E.; Wrin, J.; Koths, K. Renaturation and purification of biologically active recombinant human macrophage colony-stimulating factor expressed in E. coli. Bio/Technology 1989, 7, (7), 710-715.

(25) Orsini, G.; Brandazza, A.; Sarmientos, P.; Molinari, A.; Lansen, J.; Cauet, G. Efficient renaturation and fibrinolytic properties of prourokinase and a deletion mutant expressed in escherichia coli as inclusion bodies. Eur. J. Biochem. 1991, 195, (3), 691-697. 
(26) Kelly, S. M.; Price, N. C. Reactivation of denatured citrate synthase. Int. J. Biochem. 1992, 24, (4), 627-630.

(27) Orsini, G.; Goldberg, M. E. The renaturation of reduced chymotrypsinogen a in guanidine hcl. Refolding versus aggregation. J Biol Chem 1978, 253, (10), 34533458 .

(28) Stuart, E. B.; John, R. O.; (USA): Application: U.S 1986.

(29) Vicik, S.; De Bernardez-Clark, E. An engineering approach to achieving highprotein refolding yields. ACS Symp. Ser. 1991, 470, (Protein Refolding), 180-196.

(30) Winter, J.; Lilie, H.; Rudolph, R. Recombinant expression and in vitro folding of proinsulin are stimulated by the synthetic dithiol vectrase-p. FEMS Microbiol. Lett. 2002, 213, (2), 225-230.

(31) Gilbert, H. F. Protein disulfide isomerase and assisted protein folding. J. Biol. Chem. 1997, 272, (47), 29399-29402.

(32) Woycechowsky, K. J.; Wittrup, K. D.; Raines, R. T. A small-molecule catalyst of protein folding in vitro and in vivo. Chem. Biol. 1999, 6, (12), 871-879.

(33) Konishi, Y.; Ooi, T.; Scheraga, H. A. Regeneration of ribonuclease a from the reduced protein. Isolation and identification of intermediates and equilibrium treatment. Biochemistry 1981, 20, (14), 3945-3955.

(34) Cabrele, C.; Fiori, S.; Pegoraro, S.; Moroder, L. Redox-active cyclic bis(cysteinyl)peptides as catalysts for in vitro oxidative protein folding. Chem. Biol. 2002, 9, (6), 731-740.

(35) Gough, J. D.; Gargano, J. M.; Donofrio, A. E.; Lees, W. J. Aromatic thiol pka effects on the folding rate of a disulfide containing protein. Biochemistry 2003, 42, (40), 11787-11797.

(36) Gough, J. D.; Barrett, E. J.; Silva, Y.; Lees, W. J. Ortho- and meta-substituted aromatic thiols are efficient redox buffers that increase the folding rate of a disulfide-containing protein. J. Biotechnol. 2006, 125, (1), 39-47.

(37) Gurbhele-Tupkar, M. C.; Perez, L. R.; Silva, Y.; Lees, W. J. Rate enhancement of the oxidative folding of lysozyme by the use of aromatic thiol containing redox buffers. Bioorg. Med. Chem. 2008, 16, (5), 2579-2590.

(38) Madar, D. J.; Patel, A. S.; Lees, W. J. Comparison of the oxidative folding of lysozyme at a high protein concentration using aromatic thiols versus glutathione. J. Biotechnol. 2009, 142, (3-4), 214-219. 
(39) Gough, J. D.; Lees, W. J. Increased catalytic activity of protein disulfide isomerase using aromatic thiol based redox buffers. Bioorg. Med. Chem. Lett. 2005, 15, (3), 777-781.

(40) Weissman, J. S.; Kim, P. S. Reexamination of the folding of bpti: Predominance of native intermediates. Science (Washington, D. C., 1883-) 1991, 253, (5026), 1386-1393.

(41) Narayan, M.; Welker, E.; Wedemeyer, W. J.; Scheraga, H. A. Oxidative folding of proteins. Acc. Chem. Res. 2000, 33, (11), 805-812.

(42) Van den Berg, B.; Chung, E. W.; Robinson, C. V.; Mateo, P. L.; Dobson, C. M. The oxidative refolding of hen lysozyme and its catalysis by protein disulfide isomerase. Embo J. 1999, 18, (17), 4794-4803.

(43) DeCollo, T. V.; Lees, W. J. Effects of aromatic thiols on thiol-disulfide interchange reactions that occur during protein folding. J. Org. Chem. 2001, 66, (12), 4244-4249.

(44) Szajewski, R. P.; Whitesides, G. M. Rate constants and equilibrium constants for thiol-disulfide interchange reactions involving oxidized glutathione. J. Am. Chem. Soc. 1980, 102, (6), 2011-2026.

(45) Ferrari, D. M.; Soling, H.-D. The protein disulfide-isomerase family: Unravelling a string of folds. Biochem. J. 1999, 339, (1), 1-10.

(46) Wilkinson, B.; Gilbert, H. F. Protein disulfide isomerase. Biochim. Biophys. Acta, Proteins Proteomics 2004, 1699, (1-2), 35-44.

(47) Freedman, R. B.; Hirst, T. R.; Tuite, M. F. Protein disulfide isomerase: Building bridges in protein folding. Trends Biochem. Sci. 1994, 19, (8), 331-336.

(48) Puig, A.; Gilbert, H. F. Protein disulfide isomerase exhibits chaperone and antichaperone activity in the oxidative refolding of lysozyme. J. Biol. Chem. 1994, 269, (10), 7764-7771.

(49) Koivu, J.; Myllyla, R.; Helaakoski, T.; Pihlajaniemi, T.; Tasanen, K.; Kivirikko, K. I. A single polypeptide acts both as the $\beta$ subunit of prolyl 4-hydroxylase and as a protein disulfide-isomerase. J. Biol. Chem. 1987, 262, (14), 6447-6449.

(50) Wetterau, J. R.; Combs, K. A.; Spinner, S. N.; Joiner, B. J. Protein disulfide isomerase is a component of the microsomal triglyceride transfer protein complex. J. Biol. Chem. 1990, 265, (17), 9800-9807. 
(51) Hatahet, F.; Ruddock Lloyd, W. Protein disulfide isomerase: A critical evaluation of its function in disulfide bond formation. Antioxid Redox Signal 2009, 11, (11), 2807-2850.

(52) Edman, J. C.; Ellis, L.; Blacher, R. W.; Roth, R. A.; Rutter, W. J. Sequence of protein disulfide isomerase and implications of its relationship to thioredoxin. Nature (London) 1985, 317, (6034), 267-270.

(53) Cheung, P. Y.; Churchich, J. E. Recognition of protein substrates by proteindisulfide isomerase a sequence of the $b^{\prime}$ domain responds to substrate binding. $J$. Biol. Chem. 1999, 274, (46), 32757-32761.

(54) Koivunen, P.; Pirneskoski, A.; Karvonen, P.; Ljung, J.; Helaakoski, T.; Notbohm, H.; Kivirikko, K. I. The acidic c-terminal domain of protein disulfide isomerase is not critical for the enzyme subunit function or for the chaperone or disulfide isomerase activities of the polypeptide. Embo J. 1999, 18, (1), 65-74.

(55) Munro, S.; Pelham, H. R. B. A c-terminal signal prevents secretion of luminal er proteins. Cell (Cambridge, Mass.) 1987, 48, (5), 899-907.

(56) Kemmink, J.; Darby, N. J.; Dijkstra, K.; Nilges, M.; Creighton, T. E. Structure determination of the n-terminal thioredoxin-like domain of protein disulfide isomerase using multidimensional heteronuclear $13 \mathrm{c} / 15 \mathrm{n} \mathrm{nmr}$ spectroscopy. Biochemistry 1996, 35, (24), 7684-7691.

(57) Kemmink, J.; Darby, N. J.; Dijkstra, K.; Nilges, M.; Creighton, T. E. The folding catalyst protein disulfide isomerase is constructed of active and inactive thioredoxin modules. Curr. Biol. 1997, 7, (4), 239-245.

(58) Tian, G.; Xiang, S.; Noiva, R.; Lennarz, W. J.; Schindelin, H. The crystal structure of yeast protein disulfide isomerase suggests cooperativity between its active sites. Cell (Cambridge, MA, U. S.) 2006, 124, (1), 61-73.

(59) Goldberg, M. E.; Rudolph, R.; Jaenicke, R. A kinetic study of the competition between renaturation and aggregation during the refolding of denatured-reduced egg white lysozyme. Biochemistry 1991, 30, (11), 2790-2797.

(60) Gething, M. J.; Sambrook, J. Protein folding in the cell. Nature (London) 1992, 355, (6355), 33-45.

(61) Noiva, R.; Lennarz, W. J. Protein disulfide isomerase. A multifunctional protein resident in the lumen of the endoplasmic reticulum. J. Biol. Chem. 1992, 267, (6), 3553-3556. 
(62) Freedman, R. B. Protein disulfide isomerase: Multiple roles in the modification of nascent secretory proteins. Cell (Cambridge, Mass.) 1989, 57, (7), 1069-1072.

(63) Lyles, M. M.; Gilbert, H. F. Catalysis of the oxidative folding of ribonuclease a by protein disulfide isomerase: Dependence of the rate on the composition of the redox buffer. Biochemistry 1991, 30, (3), 613-619.

(64) Quan, H.; Fan, G.; Wang, C.-c. Independence of the chaperone activity of protein disulfide isomerase from its thioredoxin-like active site. J. Biol. Chem. 1995, 270, (29), 17078-17080.

(65) Morjana, N. A.; Gilbert, H. F. Effect of protein and peptide inhibitors on the activity of protein disulfide-isomerase. Biochemistry 1991, 30, (20), 4985-4990.

(66) Noiva, R.; Kimura, H.; Roos, J.; Lennarz, W. J. Peptide binding by protein disulfide isomerase, a resident protein of the endoplasmic reticulum lumen. $J$. Biol. Chem. 1991, 266, (29), 19645-19649.

(67) Puig, A.; Gilbert, H. F. Anti-chaperone behavior of bip during the protein disulfide isomerase-catalyzed refolding of reduced denatured lysozyme. J. Biol. Chem. 1994, 269, (41), 25889-25896.

(68) Puig, A.; Lyles, M. M.; Noiva, R.; Gilbert, H. F. The role of the thiol/disulfide centers and peptide binding site in the chaperone and anti-chaperone activities of protein disulfide isomerase. J. Biol. Chem. 1994, 269, (29), 19128-19135.

(69) Creighton, T. E. Conformational restrictions on the pathway of folding and unfolding of the pancreatic trypsin inhibitor. J. Mol. Biol. 1977, 113, (2), 275-293.

(70) Anfinsen, C. B. Principles that govern the folding of protein chains. Science 1973, 181, (4096), 223-230.

(71) Goldberger, R.; Epstein, C. J.; Anfinsen, C. B. Acceleration of reactivation of reduced bovine pancreatic ribonuclease by a microsomal system from rat liver. $J$. Biol. Chem. 1963, 238, 628-635.

(72) Braakman, I.; Hoover-Litty, H.; Wagner, K. R.; Helenius, A. Folding of influenza hemagglutinin in the endoplasmic reticulum. J. Cell Biol. 1991, 114, (3), 401-411.

(73) Hwang, C.; Sinskey, A. J.; Lodish, H. F. Oxidized redox state of glutathione in the endoplasmic reticulum. Science (Washington, D. C., 1883-) 1992, 257, (5076), 1496-1502.

(74) Frand, A. R.; Kaiser, C. A. The ero1 gene of yeast is required for oxidation of protein dithiols in the endoplasmic reticulum. Mol. Cell 1998, 1, (2), 161-170. 
(75) Pollard, M. G.; Travers, K. J.; Weissman, J. S. Erolp: A novel and ubiquitous protein with an essential role in oxidative protein folding in the endoplasmic reticulum. Mol. Cell 1998, 1, (2), 171-182.

(76) Sevier, C. S.; Cuozzo, J. W.; Vala, A.; Aslund, F.; Kaiser, C. A. A flavoprotein oxidase defines a new endoplasmic reticulum pathway for biosynthetic disulphide bond formation. Nat. Cell Biol. 2001, 3, (10), 874-882.

(77) Tu, B. P.; Ho-Schleyer, S. C.; Travers, K. J.; Weissman, J. S. Biochemical basis of oxidative protein folding in the endoplasmic reticulum. Science (Washington, D. C.) 2000, 290, (5496), 1571-1574.

(78) Frand, A. R.; Kaiser, C. A. Erolp oxidizes protein disulfide isomerase in a pathway for disulfide bond formation in the endoplasmic reticulum. Mol. Cell 1999, 4, (4), 469-477.

(79) Cuozzo, J. W.; Kaiser, C. A. Competition between glutathione and protein thiols for disulfide-bond formation. Nat. Cell Biol. 1999, 1, (3), 130-135.

(80) Chakravarthi, S.; Bulleid Neil, J. Glutathione is required to regulate the formation of native disulfide bonds within proteins entering the secretory pathway. $J$ Biol Chem 2004, 279, (38), 39872-39879.

(81) Molteni, S. N.; Fassio, A.; Ciriolo, M. R.; Filomeni, G.; Pasqualetto, E.; Fagioli, C.; Sitia, R. Glutathione limits ero1-dependent oxidation in the endoplasmic reticulum. J. Biol. Chem. 2004, 279, (31), 32667-32673.

(82) Chakravarthi, S.; Jessop, C. E.; Bulleid, N. J. The role of glutathione in disulphide bond formation and endoplasmic-reticulum-generated oxidative stress. EMBO Rep. 2006, 7, (3), 271-275.

(83) Matagne, A.; Dobson, C. M. The folding process of hen lysozyme. A perspective from the "new view". Cell. Mol. Life Sci. 1998, 54, (4), 363-371.

(84) Creighton, T. E. Intermediates in the refolding of reduced pancreatic trypsin inhibitor. J. Mol. Biol. 1974, 87, (3), 579-602.

(85) Acharya, A. S.; Taniuchi, H. Implication of the structure and stability of disulfide intermediates of lysozyme on the mechanism of renaturation. Mol. Cell. Biochem. 1982, 44, (3), 129-148.

(86) van den Berg, B.; Chung, E. W.; Robinson, C. V.; Dobson, C. M. Characterization of the dominant oxidative folding intermediate of hen lysozyme. J. Mol. Biol. 1999, 290, (3), 781-796. 
(87) Kikuchi, M.; Taniyama, Y.; Kanaya, S.; Takao, T.; Shimonishi, Y. Occurrence of s-(1,2-dicarboxyethyl)-cysteine at position 77 in mutant human lysozyme secreted by saccharomyces cerevisiae. Eur. J. Biochem. 1990, 187, (2), 315-320.

(88) Taniyama, Y.; Seko, C.; Kikuchi, M. Secretion in yeast of mutant human lysozymes with and without glutathione bound to cysteine 95. J. Biol. Chem. 1990, 265, (28), 16767-16771.

(89) Berndt, K. D.; Guentert, P.; Orbons, L. P. M.; Wuethrich, K. Determination of a high-quality nuclear magnetic resonance solution structure of the bovine pancreatic trypsin inhibitor and comparison with three crystal structures. J. Mol. Biol. 1992, 227, (3), 757-775.

(90) Bulaj, G.; Goldenberg, D. P. $\Phi$-values for bpti folding intermediates and implications for transition state analysis. Nat. Struct. Biol. 2001, 8, (4), 326-330.

(91) Creighton, T. E.; Goldenberg, D. P. Kinetic role of a meta-stable native-like twodisulfide species in the folding transition of bovine pancreatic trypsin inhibitor. $J$. Mol. Biol. 1984, 179, (3), 497-526.

(92) Creighton, T. E. Protein folding coupled to disulfide bond formation. Biol. Chem. 1997, 378, (8), 731-744.

(93) Creighton, T. E. Energetics of folding and unfolding of pancreatic trypsin inhibitor. J. Mol. Biol. 1977, 113, (2), 295-312.

(94) Goldenberg, D. P.; Creighton, T. E. Folding pathway of a circular form of bovine pancreatic trypsin inhibitor. J. Mol. Biol. 1984, 179, (3), 527-545.

(95) Goldenberg, D. P.; Frieden, R. W.; Haack, J. A.; Morrison, T. B. Mutational analysis of a protein-folding pathway. Nature (London) 1989, 338, (6211), 127132.

(96) Goldenberg, D. P. Native and non-native intermediates in the bpti folding pathway. Trends Biochem. Sci. 1992, 17, (7), 257-261.

(97) Darby, N. J.; Van Mierlo, C. P. M.; Scott, G. H. E.; Neuhaus, D.; Creighton, T. E. Kinetic roles and conformational properties of the non-native two-disulfide intermediates in the refolding of bovine pancreatic trypsin inhibitor. J. Mol. Biol. 1992, 224, (4), 905-911.

(98) Weissman, J. S.; Kim, P. S. Kinetic role of nonnative species in the folding of bovine pancreatic trypsin inhibitor. Proc. Natl. Acad. Sci. U. S. A. 1992, 89, (20), 9900-9904. 
(99) Weissman, J. S.; Kim, P. S. The pro region of bpti facilitates folding. Cell (Cambridge, Mass.) 1992, 71, (5), 841-851.

(100) Dadlez, M.; Kim, P. S. Rapid formation of the native 14-38 disulfide bond in the early stages of bovine pancreatic trypsin inhibitor (bpti) folding. Biochemistry 1996, 35, (50), 16153-16164.

(101) Lilie, H.; Schwarz, E.; Rudolph, R. Advances in refolding of proteins produced in E. Coli. Curr. Opin. Biotechnol. 1998, 9, (5), 497-501.

(102) Lees Watson, J. Small-molecule catalysts of oxidative protein folding. Curr Opin Chem Biol 2008, 12, (6), 740-745.

(103) Kiefhaber, T.; Rudolph, R.; Kohler, H. H.; Buchner, J. Protein aggregation in vitro and in vivo: A quantitative model of the kinetic competition between folding and aggregation. Bio/Technology 1991, 9, (9), 825-829.

(104) Zettlmeissl, G.; Rudolph, R.; Jaenicke, R. Reconstitution of lactic dehydrogenase. Noncovalent aggregation vs. Reactivation. 1. Physical properties and kinetics of aggregation. Biochemistry 1979, 18, (25), 5567-5571.

(105) Dong, X.-Y.; Huang, Y.; Sun, Y. Refolding kinetics of denatured-reduced lysozyme in the presence of folding aids. J. Biotechnol. 2004, 114, (1-2), 135142.

(106) Maeda, Y.; Yamada, H.; Ueda, T.; Imoto, T. Effect of additives on the renaturation of reduced lysozyme in the presence of $4 \mathrm{~m}$ urea. Protein Eng. 1996, 9, (5), 461-465.

(107) Rariy, R. V.; Klibanov, A. M. Correct protein folding in glycerol. Proc. Natl. Acad. Sci. U. S. A. 1997, 94, (25), 13520-13523.

(108) Arakawa, T.; Tsumoto, K. The effects of arginine on refolding of aggregated proteins: Not facilitate refolding, but suppress aggregation. Biochem. Biophys. Res. Commun. 2003, 304, (1), 148-152.

(109) Reddy K, R. C.; Lilie, H.; Rudolph, R.; Lange, C. L-arginine increases the solubility of unfolded species of hen egg white lysozyme. Protein Sci. 2005, 14, (4), 929-935.

(110) Wetlaufer, D. B.; Xie, Y. Control of aggregation in protein refolding: A variety of surfactants promote renaturation of carbonic anhydrase ii. Protein Sci. 1995, 4, (8), 1535-1543. 
(111) Zardeneta, G.; Horowitz, P. M. Detergent, liposome, and micelle-assisted protein refolding. Anal. Biochem. 1994, 223, (1), 1-6.

(112) Cleland, J. L.; Builder, S. E.; Swartz, J. R.; Winkler, M.; Chang, J. Y.; Wang, D. I. C. Polyethylene glycol enhanced protein refolding. Bio/Technology 1992, 10, (9), 1013-1019.

(113) Mendoza, J. A.; Rogers, E.; Lorimer, G. H.; Horowitz, P. M. Chaperonins facilitate the in vitro folding of monomeric mitochondrial rhodanese. J. Biol. Chem. 1991, 266, (20), 13044-13049.

(114) Rozema, D.; Gellman, S. H. Artificial chaperone-assisted refolding of denaturedreduced lysozyme: Modulation of the competition between renaturation and aggregation. Biochemistry 1996, 35, (49), 15760-15771.

(115) Yasuda, M.; Murakami, Y.; Sowa, A.; Ogino, H.; Ishikawa, H. Effect of additives on refolding of a denatured protein. Biotechnol. Prog. 1998, 14, (4), 601-606.

(116) Woycechowsky, K. J.; Hook, B. A.; Raines, R. T. Catalysis of protein folding by an immobilized small-molecule dithiol. Biotechnol. Prog. 2003, 19, (4), 13071314.

(117) Gough, J. D.; Lees, W. J. Effects of redox buffer properties on the folding of a disulfide-containing protein: Dependence upon ph, thiol pka, and thiol concentration. J. Biotechnol. 2005, 115, (3), 279-290.

(118) Basu, P.; Nemykin, V. N.; Sengar, R. S. Syntheses, spectroscopy, and redox chemistry of encapsulated oxo-mo(v) centers: Implications for pyranopterincontaining molybdoenzymes. Inorg. Chem. 2003, 42, (23), 7489-7501.

(119) Newman, M. S.; Karnes, H. A. Conversion of phenols to thiophenols via dialkylthiocarbamates. J. Org. Chem. 1966, 31, (12), 3980-3984.

(120) Moss, R. A.; Dix, F. M. Properties of phenolic and thiophenolic surfactant micelles. J. Org. Chem. 1981, 46, (15), 3029-3035.

(121) Aitken, R. A.; Drysdale, M. J.; Ryan, B. M. Flash vacuum pyrolysis of stabilized phosphorus ylides. Part 13. Extrusion of ph3p from sulfinyl ylides and reactivity of the resulting sulfinyl carbenes. J. Chem. Soc., Perkin Trans. 1 1998, (20), $3345-3348$.

(122) Coogan, M. P.; Harger, M. J. P. Nucleophilic substitution in benzylic thiophosphinyl and thiophosphonyl chlorides: The contribution of eliminationaddition pathways with methylenethioxophosphorane (thiophosphene) intermediates. J. Chem. Soc., Perkin Trans. 2 1994, (10), 2101-2107. 
(123) Kawai, H.; Sakamoto, F.; Taguchi, M.; Kitamura, M.; Sotomura, M.; Tsukamoto, G. 2-oxo-1,3-dioxoles as specific substrates for measurement of arylesterase activity. Chem. Pharm. Bull. 1991, 39, (6), 1422-1425.

(124) Woehrle, G. H.; Warner, M. G.; Hutchison, J. E. Molecular-level control of feature separation in one-dimensional nanostructure assemblies formed by biomolecular nanolithography. Langmuir 2004, 20, (14), 5982-5988.

(125) Steinem, C.; Janshoff, A.; von dem Bruch, K.; Reihs, K.; Goossens, J.; Galla, H.J. Valinomycin-mediated transport of alkali cations through solid supported membranes. Bioelectrochem. Bioenerg. 1998, 45, (1), 17-26.

(126) Sengar, R. S.; Nemykin, V. N.; Basu, P. Electronic properties of para-substituted thiophenols and disulfides from $13 \mathrm{c}$ nmr spectroscopy and ab initio calculations: Relations to the hammett parameters and atomic charges. New J. Chem. 2003, 27, (7), 1115-1123.

(127) Jacobson, R. M.; Kelly, M. J.; Wehmeyer, F. L.; Evans, K. A.; (USA). Application: US 2005, p 35 pp.

(128) Perraudin, J. P.; Torchia, T. E.; Wetlaufer, D. B. Multiple parameter kinetic studies of the oxidative folding of reduced lysozyme. J. Biol. Chem. 1983, 258, (19), 11834-11839.

(129) Wetlaufer, D. B.; Saxena, V. P. Formation of three-dimensional structure in proteins. I. Rapid nonenzymic reactivation of reduced lysozyme. Biochemistry 1970, 9, (25), 5015-5023.

(130) Sophianopoulos, A. J.; Rhodes, C. K.; Holcomb, D. N.; Van Holde, K. E. Physical studies of lysozyme. I. Characterization. J. Biol. Chem. 1962, 237, 11071112.

(131) Roux, P.; Delepierre, M.; Goldberg, M. E.; Chaffotte, A. F. Kinetics of secondary structure recovery during the refolding of reduced hen egg white lysozyme. $J$. Biol. Chem. 1997, 272, (40), 24843-24849.

(132) Jolles, P. Lysozymes from rabbit spleen and dog spleen. Methods Enzymol. 1962, $5,137-140$.

(133) Benesch, R. E.; Benesch, R. The acid strength of the -sh group in cysteine and related compounds. J. Am. Chem. Soc. 1955, 77, 5877-5881.

(134) Lees, W. J.; Singh, R.; Whitesides, G. M. Meso-2,5-dimercapto- $N, N, N^{\prime}, N^{\prime}-$ tetramethyladipamide: A readily available, kinetically rapid reagent for the 
reduction of disulfides in aqueous solution. J. Org. Chem. 1991, 56, (26), 73287331.

(135) Hawkins, H. C.; Freedman, R. B. The reactivities and ionization properties of the active-site dithiol groups of mammalian protein disulfide-isomerase. Biochem. J. 1991, 275, (2), 335-339.

(136) Creighton, T. E. Two-disulfide intermediates and the folding pathway of reduced pancreatic trypsin inhibitor. J. Mol. Biol. 1975, 95, (2), 167-199.

(137) Bach, R. D.; Dmitrenko, O.; Thorpe, C. Mechanism of thiolate-disulfide interchange reactions in biochemistry. J. Org. Chem. 2008, 73, (1), 12-21.

(138) Epstein, C. J.; Goldberger, R. F. Factors influencing the reactivation of reduced egg white lysozyme. J. Biol. Chem. 1963, 238, 1380-1383.

(139) Dobson, C. M.; Evans, P. A.; Radford, S. E. Understanding how proteins fold: The lysozyme story so far. Trends Biochem. Sci. 1994, 19, (1), 31-37.

(140) Lanckriet, H.; Middelberg, A. P. J. Continuous chromatographic protein refolding. J. Chromatogr., A 2004, 1022, (1-2), 103-113.

(141) Ellman, G. L. Tissue sulfhydryl groups. Arch. Biochem. Biophys. 1959, 82, 70-77. 
VITA

AMAR S. PATEL

September 16, 1978

Born, Dahanu, Maharashtra, India

August 1996-June 2000

Bachelors of Pharmacy

Nagpur University, India

September 2000-July 2002

Assistant chemist, Western India Laboratories

Borsad, Gujarat, India

November 2002-July 2004

Masters of Pharmacy (Pharmacology)

Pune University, India

August 2004-July 2005

Research Scientist, Suven Life Sciences

Hyderabad, Andhra Pradesh, India

August 2005-December 2010

Doctoral candidate in chemistry

Florida International University,

Miami, Florida, USA

August 2005-April 2010

Teaching assistant/Research assistant

Florida International University,

Miami, Florida, USA

$\underline{\text { Publications and Presentations: }}$

- David J. Madar, Amar S. Patel, and Watson J. Lees "Comparison of the oxidative folding of lysozyme at a high protein concentration using aromatic thiols versus glutathione" J. Biotechnol. 142 (3-4), 2009, 214-219

- Amar S. Patel, Watson J. Lees "Aromatic dithiols: Increasing the folding rate an yield of disulfide containing proteins" 240th ACS National Meeting and Symposium, Boston, MA (Aug 22- 26, 2010)

- Amar S. Patel, David J. Madar, Elvis J. Barrett, and Watson J. Lees "Comparative studies of aromatic monothiols and dithiols, and glutathione for the folding of lysozyme" 239th ACS National Meeting and Symposium, San Francisco, CA (March 21-25, 2010)

- Amar S. Patel, Watson J. Lees "Synthesis of aromatic dithiols. To increase the folding rate and yield of in vitro folding of disulfide containing proteins" FAME 2008, Orlando, FL, USA (May 8-10 2008) 
- Vikas S. Shirsath, Santosh L. Vishwakarma, Renny Abraham, Amar S. Patel, Ravindra S. Kanchi, Sastry R. Kambhampati, and Ramakrishna V. S. Nirogi "Effect of selective 5- $\mathrm{HT}_{6}$ receptor antagonists SUVN-501 and SUVN-502 in a rodent model of working memory" Society for Neuroscience 2005, Washington DC, USA. (November 12-16, 2005)

- Vishal V. Pendharkar, Santosh L. Vishwakarma, Amar S. Patel, Vikas S. Shirsath, Sastry R. Kambhampati, and Ramakrishna V. S. Nirogi "Effect of selective 5-HT 6 receptor antagonists on food intake and body weight gain" Society for Neuroscience 2005, Washington DC, USA. (November 12-16, 2005)

- Amar S. Patel, Sonali S. Nipate, Mohan M. Ghaisas, Sheeal P. Zambad, Avinash D. Deshpande "Studies on the influence of Piper betle Linn Family- Piperaceae on the central nervous system in experimental animals", first International conference on Natural products and Molecular therapy, Cape town, South Africa (January 12-14, 2005)

- Kaushal Jani, Amar S. Patel, Mohan M. Ghaisas, Sheeal P. Zambad, Avinash D. Deshpande "Effect of administration of a polyherbal formulation with glipizide and rosiglitazone on serum glucose lowering in rats" Indian Pharmaceutical Society, January 2005, India

- Kaushal Jani, Amar S. Patel, Mohan M. Ghaisas, Sheeal P. Zambad, Avinash D. Deshpande "Evaluation of hypoglycemic activity of a polyherbal formulation in wistar rats," $56^{\text {th }}$ Indian Pharmaceutical Congress 2004, Kolkatta, India

- Amar S. Patel, Puspharaj Gupta, Mohan M. Ghaisas, Sheeal P. Zambad, Avinash D. Deshpande "Comparative evaluation of some ayurvedic preparations for their analgesic and anti inflammatory properties," $55^{\text {th }}$ Indian Pharmaceutical Congress 2003, Chennai, India

\section{Awards and Affiliations:}

- Dissertation Year Fellowship: University Graduate School, Florida International University for Summer 2010 to Spring 2011

- ACS member 